\title{
Working time arrangements
}

Citation for published version (APA):

Peters, V. P. J. M. (2019). Working time arrangements: a tool to improve work participation of nurses working in residential elder care? [Doctoral Thesis, Maastricht University]. Ridderprint BV. https://doi.org/10.26481/dis.20190111vp

Document status and date:

Published: 01/01/2019

DOI:

10.26481/dis.20190111vp

Document Version:

Publisher's PDF, also known as Version of record

\section{Please check the document version of this publication:}

- A submitted manuscript is the version of the article upon submission and before peer-review. There can be important differences between the submitted version and the official published version of record.

People interested in the research are advised to contact the author for the final version of the publication, or visit the DOI to the publisher's website.

- The final author version and the galley proof are versions of the publication after peer review.

- The final published version features the final layout of the paper including the volume, issue and page numbers.

Link to publication

\footnotetext{
General rights rights.

- You may freely distribute the URL identifying the publication in the public portal. please follow below link for the End User Agreement:

www.umlib.nl/taverne-license

Take down policy

If you believe that this document breaches copyright please contact us at:

repository@maastrichtuniversity.nl

providing details and we will investigate your claim.
}

Copyright and moral rights for the publications made accessible in the public portal are retained by the authors and/or other copyright owners and it is a condition of accessing publications that users recognise and abide by the legal requirements associated with these

- Users may download and print one copy of any publication from the public portal for the purpose of private study or research.

- You may not further distribute the material or use it for any profit-making activity or commercial gain

If the publication is distributed under the terms of Article $25 \mathrm{fa}$ of the Dutch Copyright Act, indicated by the "Taverne" license above, 


\section{WORKING TIME ARRANGEMENTS \\ A Tool To Improve Work Participation Of Nurses \\ Working In Residential Elder Care?}

Velibor Peters 


\section{WORKING TIME ARRANGEMENTS}

A Tool To Improve Work Participation Of Nurses

Working In Residential Elder Care?

Dissertation

The research presented in this thesis was conducted at HAN University of Applied Sciences and at CAPHRI Care and Public Health Research Institute, Department of Social Medicine, of Maastricht University. CAPHRI participates in the Netherlands School of Public Health and Care Research CaRe.

\section{Maastricht University (9) CAPHRI}

WORKING TIME ARRANGEMENTS: A Tool To Improve Work Participation Of Nurses Working In Residential Elder Care? | VELIBOR PETERS

Copyright @ 2019 Velibor Peters, Nijmegen 2019

All rights are reserved. No part of this thesis may be reproduced, distributed or transmitted in any form or by any means without prior written permission of the author.

Cover design: Elisa Calamita, persoonlijkproefschrift.nl

Lay-out and design: Elisa Calamita, persoonlijkproefschrift.nl

Printing: Ridderprint BV | www.ridderprint.nl

ISBN/EAN: 978-94-6375-220-6

NUR: 100

to obtain the degree of Doctor at Maastricht University, on the authority of the Rector Magnificus, Prof. Dr. R. M. Letschert in accordance with the decision of the Board of Deans, to be defended in public

on Friday, $11^{\text {th }}$ January 2019 , at 14.00 Hours

Velibor Peters 


\section{Promotoren}

Prof. dr. IJ. Kant

Prof. dr. A.E. de Rijk

\section{Co-promotor}

Dr. J.A. Engels (Hogeschool van Arnhem en Nijmegen)

Beoordelingscommissie

Prof. dr. F.R.H. Zijlstra (voorzitter)

Prof. dr. A.J. van der Beek (VUmc Amsterdam)

Prof. dr. J.P.H. Hamers

Prof. dr. B.I.J.M. van der Heijden (Radboud Universiteit Nijmegen)

\section{CONTENTS}

Chapter 1

General Introduction

Chapter $2 \quad$ Nurses' Satisfaction With Shiftwork And Associations With Work, Home And Health Characteristics: A Survey In The Netherlands

Chapter 3 A New Typology Of Work Schedules: Evidence From A CrossSectional Study Among Nurses Working In Residential Elder Care.

Chapter $4 \quad$ Sustainable Employability In Shiftwork: Related To Types Of Work Schedule Rather Than Age.

Chapter $5 \quad$ Which Resources Moderate The Effects Of Demanding Work Schedules On Nurses Working In Residential Elder Care? A Longitudinal Study.

Chapter 6 Sickness Absence Of Nurses Working In Residential Elder Care: Both Job- And Home-Related.

Chapter 7

General Discussion

\section{Summary}

Samenvatting

Valorisation

Dankwoord

About The Author

List Of Publications 
Societal and demographic developments, such as a longer working life, a higher retirement age and low participation rates, increase the need to further examine work participation. The western population is 'greying': for example, it is estimated that, in the Netherlands, by 2038 about $25 \%$ of the population will be over 65 years of age $(1,2)$. Also, in the EU-27, between 2010 and 2030 the working population aged 55 to 64 years is expected to increase by about $16 \%$ (4). In the Netherlands, the old-age dependency ratio, i.e. the level of (financial) support given to older persons by the working-age population, will increase from 1:4 to 1:2 by 2038 (1). The ageing population poses important challenges for social security and welfare programmes including pensions, health care and long-term care. At a societal level, it is important to raise labour participation levels in view of the old-age dependency ratio. Apart from strategies to discourage early retirement and encourage a longer working life, special attention should be paid to raising the participation rates of women, older workers and starters on the labour market.

Participation is seen as an aspect of human functioning on a social and societal level, and the outcome of an interaction between a person's health, and their personal and environmental factors. This thesis focuses on sickness absence, reduced well-being and reduced motivation as major components of work participation $(3,5-7)$. In the Netherlands, the sickness absence rate is relatively high among women, older employees, employees with a low level of education, and employees with a chronic or long-term health problem (8). Participation rates differ between sectors, with each sector having its own distinctive problems (8-11).

In the Netherlands, the largest part of the total work force works in the healthcare sector, i.e. an estimated $18-22 \%$. The healthcare sector has relatively high absence rates which are comparable to other sectors, such as public administration and transport (8). Moreover, in particular, the healthcare sector is threatened by a shortage of nurses on the labour market; this situation is likely to increase not only in the Netherlands, but also globally (12-14). Importantly, a nursing shortage may jeopardise the efficiency and quality of care (15).

Of all healthcare employees, about $30 \%$ works in elder care $(8,16)$, making elder care the largest employer within the healthcare sector. Of this $30 \%, 62 \%$ works in residential elder care (16). In the Dutch healthcare sector, nurses working in residential elder care have among the highest sickness absenteeism levels and are exposed to a relatively poor work environment (17). In addition, this subgroup of nurses has among the highest rates for job leave in the healthcare sector and often shows the lowest levels of job satisfaction $(17,18)$.

Moreover, the shortage of residential elder care nurses will increase due to the demographics of the nursing population, i.e. fewer young nurses enter elder care to replace those who leave. The proportion of older nurses (aged $>55$ years) is increasing and a relatively high proportion move from employment into retirement. Also, it is a predominantly female and increasingly olderaged population, two characteristics which are associated with higher rates of sickness absence $(8,19,20)$. The shortage of nurses is also expected to increase due to an expanded demand for nurses, i.e. the increasing life expectancy and the ageing of the general population will lead to an increasing demand for elder care services. Furthermore, due to longevity and improved medical treatment, there is a growing number of persons with a chronic disease, which implies higher and more complex care requirements. Consequently, there will be an increasing demand for especially higher-educated nursing personnel as well as (evolving) new skills in elder care $(16,21)$. Therefore, care organisations need to consider how to increase the labour participation of nurses in residential elder care in order to maintain the quality of care at a high level. In the context of this thesis, labour participation refers to nurses who are aged 18 years and over and who have (at least) one type of formal job attachment with the participating care organisations.

In conclusion, and in line with the Action plan for the EU health workforce $(22,23)$, studies are needed that offer insight into how to promote the participation of nurses working in residential elder care. This need was recently emphasised by the Dutch Government and by national organisations for nurses working in elder care $(24,25)$. Although technical innovations (e.g. robots and telemetry) and social innovations (e.g. innovative assisted-living centres) may reduce the workload, these innovations will not entirely solve the problem of a nursing shortage. Therefore, there is an ongoing need to focus on nurses already working in residential elder care and their sustainable employment; this is the main aim of the work in this thesis.

\section{DETERMINANTS OF LABOUR PARTICIPATION OF NURSES}

Labour participation is a multifaceted and complex phenomenon which may involve i) workrelated factors, ii) personal factors, and iii) health-related factors. In this thesis, the International Classification of Functioning, Disability and Health (the ICF), extended with the model of Van Dijk (3), was considered to be a suitable frame of mind to study the labour participation of residential elder care nurses, since it acknowledges the role of contextual factors (Figure 1). The ICF encompasses functioning as a universal human experience that can be conceptualised and classified from different perspectives, i.e. the perspective of the body (body functions and structures), of the individual (activities), and of society (including labour participation). Functioning can be influenced by a disease/ disorder, as well as by external factors (e.g. work environment, family life, organisational features) and personal factors. In this thesis, the terms 'health' and 'health state' are used to indicate both the (threatening) disease/disorder, and the functioning of the person. This is in accordance with the broad definition of health as reported by the World Health Organisation ('Health is a state of complete physical, mental, and social well-being and not merely the absence of disease or infirmity). In line with this expanded ICF framework, three domains of external factors emerge that might influence the labour participation of nurses working in residential elder care: 1) work-related external factors, which also encompass working time arrangements, 2) home-related external factors, and 3) personal factors. In the ICF framework, participation is seen as an aspect of functioning and 
is conceived as a dynamic interaction between the other aspects of functioning and the externa factors. These three domains of external factors are also underpinned by other work stress models that assume comparable factors, and their interactions, to influence participation (26-29). These work-related and home-related external factors, as well as the personal factors and the potentia of resources, are described below.

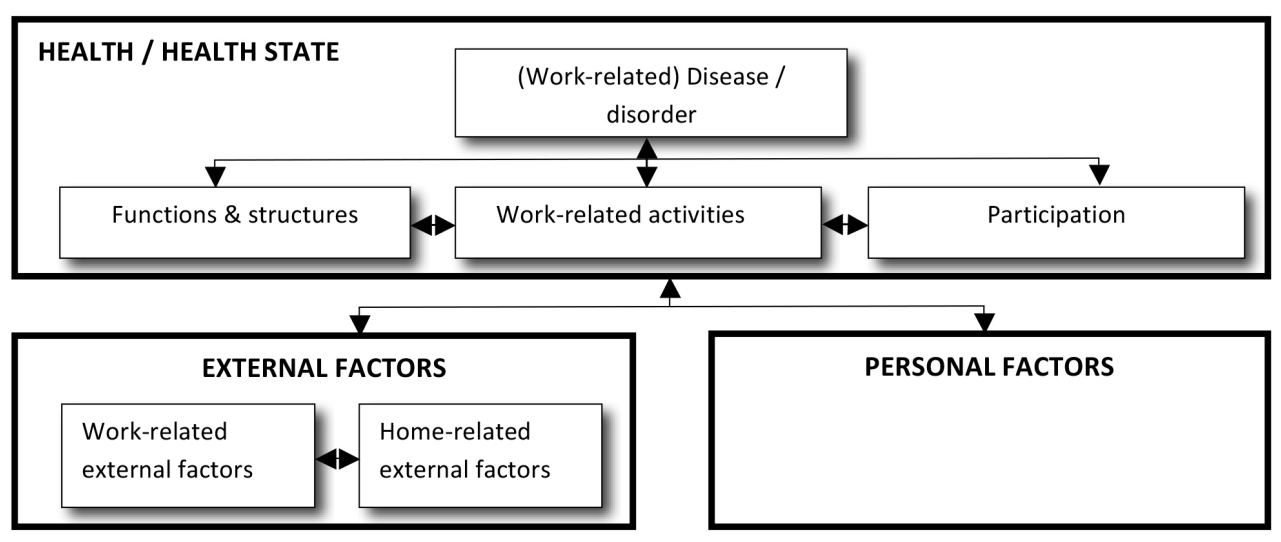

Figure 1: The ICF framework used to describe work related factors (3)

\section{Work-related external factors}

Research in general, and among nurses in particular, shows that work-related factors play a role in adverse work outcomes, e.g. ill health and sickness absence (20,30-36). Due to the increasing nursing shortage, job demands are likely to increase in the near future. Both Labriola et al. (37) and Nielsen et al. (38) reported that differences in physical and psychosocial work environment exposures account for a substantial part of the cases of high sickness absence. In general, an estimated $25 \%$ of sickness absence prevalence in 2005 and $22 \%$ in 2010 was found to be work related (39). However, most of these findings were based on health-related theories regarding the unhealthy workplace, stemming from the work stress paradigm (28), such as the Job DemandControl model $(40,41)$ or the Job Demands-Resource model $(42)$. In particular, work-related demands for nurses working in residential elder care are the physical job demands (e.g. lifting, or twisted working positions) and the psychosocial demands (e.g. time pressure, emotional demands, and lack of supervisory support) $(11,34,43,44)$.

\section{Work schedule-related external demands}

Another specific demand is the working time arrangement of a nurse, including shift work and the actual number of working hours. Shift work is inextricably bound with nursing in residential elder care. In research, shift work is often broadly defined as working outside the normal daytime hours (45-47). In Europe, besides a regular day shift, about $80 \%$ of the nurses has to work in some kind of irregular work schedule (18). However, work schedules are becoming more diverse (48, 49) and the work schedule of nurses usually changes during their career. In the Netherlands, the numbers of hours worked are an import aspect of the job and vary considerably due to the widely accepted options for part-time work (50); in addition, compared with other European countries, the Netherlands is a leading country regarding part-time work (51). Also internationally, a wide variety of work schedules is found among healthcare personnel (52). Importantly, in contrast with (for example) industrial sectors that generally have 8-hour shifts provided in 2, 3 or 5 shifts (53), the number of hours worked by nurses in residential elder care is hardly related to the work schedule (54). Moreover, a proportion of the working hours is vulnerable to change, causing unpredictable and uncontrollable work schedules.

The negative effects of shift work on health and participation is well documented, whereas studies on the specific effects of shift work for nurses working in residential elder care are scarce. However, such research is important, because shift work is associated with a wide range of negative consequences and includes self-rated health, fatigue, work-home interference, job satisfaction, decline in performance, sick leave, and even cancer (27, 55-63). Several mechanisms are assumed to explain the effect of shift work on participation in terms of well-being, motivation and sickness absence. According to Knutsson (59) and Barton et al. (64), work schedule features (or shift work) can affect health and well-being, mediated by a mismatch of sleep-wake cycles and other important biological rhythms, as well as sleep problems, lifestyle changes, or disturbed family and social life.

Besides being related to health problems, shift work is also linked to sick leave. However, data in relation to sick leave are not consistent and the underlying causal pathway remains unclear. For example, shift work has been judged by healthcare workers to be a demand or hindrance whereas, according to observer ratings, shift work has also been valued as a resource (65). These conflicting findings emphasise: i) the need for research on the specific effects of shift work on nurses working in residential elder care, as well as ii) the need to describe how work-related factors, particularly the type of work schedule, is perceived by nurses. A meta-analysis performed by Merkus et al. (46) suggests that the association between shift work and sickness absence may be schedule and population specific. Bourbonnais et al. (66) and Tuchsen et al. (67) found effects for fixed evening work on sickness absence among female nurses. Furthermore, work schedules and working hours are also high on the list of factors that contribute not only to nurses leaving the profession, but also to a decreasing quality of care $(31,49,68-72)$. Recent findings show that a large proportion of nurses working in elder care is still dissatisfied with the measures taken with respect to roster and working times, and with respect to balancing work and family (73). 


\section{Home-related external demands}

Home characteristics, having children at home and/or being a caregiver also need to be considered when investigating health, job and sick leave in nurses in elder care. The work and family domain are inextricably bound with each other $(26,29,74,75)$, particularly for this mainly female nursing population that is expected to combine work and care for children (76). Nurses may experience stress not only because of their work, but also because of the interaction between their work and home situation $(68,77)$. Nurses with a demanding home situation probably need to invest more effort in order to arrange and fulfil their responsibilities. This could lead to a depletion of resources $(74,75,77-79)$ and eventually result in health problems. This means that home demands and resources are mediated by health and/or motivation. For example, in their longitudinal research among white-collar workers, Ten Brummelhuis et al. (74) found that psychosocial home demands predicted sickness absence duration via health problems. With respect to nursing, the combination of many tasks and little social support at home is associated with health problems $(77,79,80)$. Although home characteristics might be important in predicting the sickness absence of nurses, the effects of home characteristics on sickness absence is not well documented (74).

\section{POTENTIAL ROLE OF RESOURCES}

The above-mentioned studies demonstrate that nursing can be a highly demanding and complex job. A central hypothesis of this thesis is that certain resources have the potential to buffer the negative effect of demands on the participation problems of nurses working in residential elder care. Despite the growing interest in the benefits of work (instead of focusing on only negative effects), such benefits have hardly been reflected in conceptual frameworks in research on nurses working in residential elder care (81). In this thesis, the 'Conservation of Resources' (COR) theory (82-84) is considered appropriate in order to emphasise the effect of demands, as well as that of resources, on health, work engagement, well-being and participation. According to the COR theory, people attempt to obtain, retain, and protect resources. Stress results when they risk or actually lose these resources, when faced with the threat of resource loss, or with a lack of resource gain after the investment of resources (82-84). Resources are entities that have intrinsic or instrumental value and are found in the social contexts, including objects, conditions, personal resources, and energy resources (82-84). The COR theory assumes that there are two ways nurses might react when they encounter stressors in their environment and how those encounters can influence their well-being. The first assumption of the COR theory is a 'loss spiral'; here, people attempt to obtain, retain, and protect resources and stress occurs when they risk losing, or actually lose, such resources (82-84). For example, nurses who experience high levels of stress want to keep or regain their energy by reporting ill.
The second assumption of the COR theory is a 'gain spiral': here, resources can generate new resources. In the absence of stressors, people strive to obtain more resources. This activity creates buffers for more difficult times and increases well-being because additional resources are valued (85). Social support, assisting with home duties, or advice from their partner, may help nurses to overcome work problems and, subsequently, increase motivation and performance at work (86). They experience more physical and psychological resources allowing them to invest further in resources, rather than preventing the loss of resources $(75,86,87)$. This process could lead to decreased sickness absence. However, the question remains as to whether resources related to sickness absence are mediated by well-being and/or motivation. Although the relationship between work-related external resources and well-being, motivation and sickness absence is well documented (88), few studies have examined how personal and home resources determine negative and positive consequences $(81,88,89)$

In the following sections, the work-related, home-related and personal resources are described, and are hypothesized as a possible solution to the labour participation problems of nurses together with a way in which this hypothesis can be tested.

\section{Work-related external resources}

Work-related resources, such as working time arrangements, are assumed to be important for nurses to increase their participation (90-92) and are considered particularly important when demands are high. Because work-related demands seem inevitable within nursing and are difficult to reduce on the short term (25), this thesis focuses on modifiable resources. Although the direct effects of work-related resources on sickness absence have been reported, they are assumed to predict sickness absence mediated by lower motivation and more health complaints $(28,30,36,93)$. In addition, work-related resources are assumed to have a direct positive effect on motivation and to buffer the effect of demands on health and sickness absence. Specifically, the effect of resources depends on the correspondence with the specific work-related demands $(41,42)$. Since the focus of this thesis is on nurses with shift work, two potentially important work-related external resources for nurses are: the social support of colleagues and supervisors, and (work schedule) control (94-98)

\section{Home-related external resources}

The home situation is not only perceived as a demand, but also as a resource for nurses to withstand the demands of the job. Being part of a family can prevent the development of health problems among nurses (85). According to the COR theory, this could allow them to invest further in resources, rather than preventing a loss of resources $(75,86,87)$. For example, nurses with a socially supportive home (e.g. practical or emotional help from partner, friends, etc.) (99) or more autonomy at home (e.g. deciding when/how different care tasks are performed) seem better equipped to handle stressful circumstances and avoid problematic situations. Furthermore, home 
resources can positively influence performance (86). Comparable to the mediated pathway of workrelated external resources to sickness absence, it will be tested whether home resources negatively influence sickness absence via higher motivation and fewer health complaints (74).

\section{Personal Resources}

Because there is considerable variability in the extent to which nurses adapt to shift work (100), it is important to establish whether personal resources have an impact on participation, or mitigate the effect of demands on participation. Personal resources are aspects of the self (personal characteristics and skills) that are generally linked to resilience. They pertain to an individual's ability to successfully control and influence their environment, especially during challenging circumstances (101). Personal resources of a more practical behavioural nature are expected to moderate the negative consequences of work schedule demands $(88,89,102-104)$. Accordingly, these personal factors (e.g. coping strategies or a healthy lifestyle) could determine or moderate the impact of work-related external factors on stress, subjective health, cardiovascular disease and burnout $(26,55,89,104-106)$. Specifically, active coping is a key personal resource in the COR theory, as it reflects aspects of the self that are generally linked to resilience (107). For example, employees with an active coping style are more likely to have fewer sickness absence episodes and of a shorter duration (108). Among nurses, an active coping style seems to protect against burnout (109-112) and also moderate the negative health effects of work-related demands on the dimensions of burnout $(109,112)$. In this thesis, it will be examined whether personal resources influence motivation and well-being, or moderate the impact of demands on motivation and well-being.

\section{Potential of working time arrangements as a resource}

Besides the detrimental effect of working time arrangements on participation, they can also provide opportunities to increase participation of nurses working in residential elder care. As mentioned, the varying working time arrangements are an important characteristic of nursing in residential elder care. Research on working time arrangements covers not only nightshifts and shift lengths, but also unsocial working hours (113). Unsocial working hours can cause problems in combining work and family life; in the Netherlands, such problems are particularly prevalent among a (mainly) female nursing population that has to combine work and care (76). The choice for the type of schedule is, to some extent, left to the preference of the nurses themselves and to their supervisors $(92,114)$. These choice options are expected to increase $(48,69)$ due to nursing shortages and the increasing numbers of freelance nurses $(21,115)$ and, in that case, these choice options create opportunities for nurses to work their preferred schedule. However, a change in working time arrangements is frequently imposed by the employer; in these circumstances, it threatens the resource $(92,116)$
Female nurses might prefer or choose a certain type of work schedule as a way to enhance family life, fulfil childcare needs, and adapt to their partner's job and other social roles $(117,118)$. The advantages of non-standard working hours include: being able to spend more time with the children, bringing the children to school, and taking care of the family and/or parents (119). Furthermore, women with preschool-age children are more likely to report child care as their main reason for working shifts (120). In this way, in contrast to the chain of shift work possibly leading to social disruption and health problems, the schedule itself can be seen as a working time arrangement to withstand nursing demands, that keeps nurses motivated and might increase participation in terms of well-being, motivation and sickness absence. An indication of this work schedule preference (even a very demanding work schedule) as a resource was shown (for example) in the NEXT study; here, the prevalence of permanent nightshifts increased from $1.6 \%$ in the youngest group to $8.1 \%$ in the oldest group, and this type of schedule was appreciated by $80 \%$ of the nurses with regard to their private life (18). The same process may exist for employees with health problems. For example, Boot et al. (121) showed that, among chronically ill employees, working in the evening or night shifts significantly decreased sickness absence. Furthermore, De Raeve et al. (122) showed that employees adapt to mental health problems by reducing their working hours or by leaving shift work. These employees may have chosen the preferred type of work schedule that best fits their private or individual needs. Therefore, it is debatable whether the type of work schedule for nurses working in residential elder care is an important working time arrangement to increase health, motivation and participation.

\section{Work schedule fit with private life as a resource}

Therefore, it appears that an indicator and potentially important resource could be the work schedule fit with a nurse's private life, or fit with a nurse's individual needs. It is important how nurses perceive their work schedule with respect to their private life preferences $(18,52,78,90)$. Decisions and choices around scheduling are probably influenced by nurses' family considerations, especially for nurses with more extensive family responsibilities (123). According to Holtom et al., (124) employees will be more satisfied with a type of work schedule that fits their needs. Similarly, Nabe-Nielsen et al. (52) showed that a misfit between a preferred schedule and the actual schedule negatively affects work-related attitudes (52). Also, Krausz (90), and Sturman and Walsh (125), reported that the work schedule fit was even more important with respect to work-related attitudes than the actual work schedule. However, a limitation is that most of this latter research mainly concerned working hours, and not the type of work schedule. Furthermore, only misfit was measured, not taking into account the origin or the extent of the misfit. Therefore, for this thesis, a new instrument was required to measure work schedule fit with private life.

In conclusion, there are sufficient reasons to hypothesise that nurses' participation in terms of well-being, motivation and sickness absence might be enhanced by working the schedule 
that best fits their family, personal and/or private needs. In view of the current variety of types of work schedules, it is important to elucidate which working time arrangements (e.g. the types of work schedule) are beneficial and which are detrimental to nurses' participation in terms of well-being, motivation and sickness absence. The nurses' perception of the work schedule fit with their private life could be a useful measure of this, and an essential resource to increase health motivation and participation in spite of work, home and person-related demands and risk factors. It also meets the requirements that resources should correspond with the demands related to the work schedule (41). However, until now, nurses' perception of the work schedule fit with their private life is hardly reflected in research as a resource to withstand work-related demands and to enhance well-being and motivation. Therefore, it is important to test the role with respect to and in relationship with nurses' participation, besides the above-mentioned work-related, homerelated and person-related demands and resources. Also, it is hypothesized that the effect of the work schedule fit with nurses' private life on sickness absence might be mediated by well-being or motivation. Moreover, the domain of personal factors is a topic still under discussion (126). For this thesis, incorporating resources into the extended ICF model has led to the conceptual model presented in Figure 2. In this thesis, in contrast with (for example) Heerkens et al. (3), motivation is considered to be an attitudinal work outcome and, in line with the COR theory, to be the outcome of personal and external factors and their interactions (127).

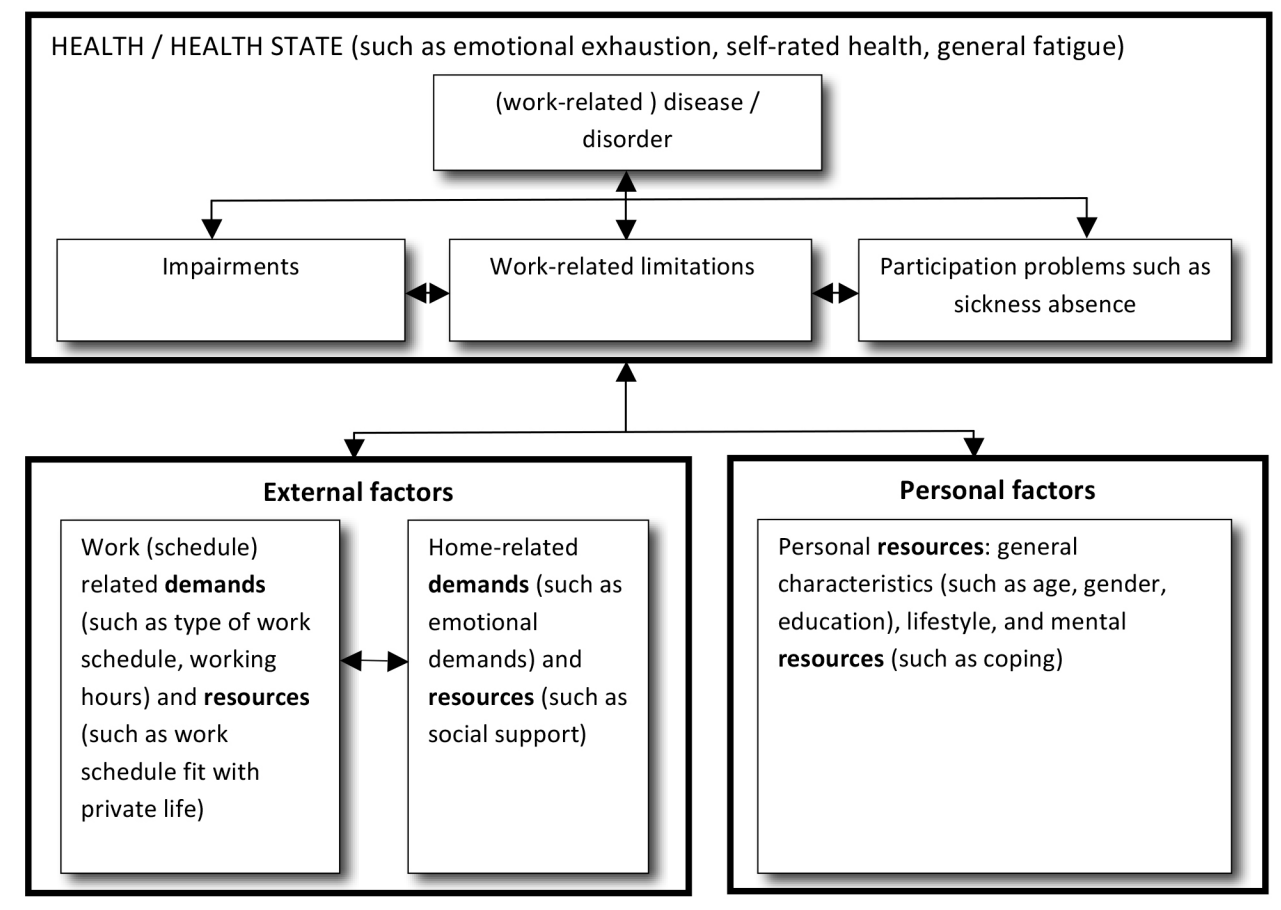

Figure 2: Conceptual, extended ICF model to study the work participation of nurses
To maintain quality of care at a high level, care organisations need to apply preventive measures to increase the participation of nurses in residential elder care. To clarify whether the work schedule, and the fit between the work schedule with private life, is a useful resource of nurses working in residential elder care (besides the personal, home and work-related external factors), it is necessary to examine the following:

1. How to measure the work schedule fit with nurses' private life

2. Which type of work schedule nurses in residential elder care work in, and whether differences exist with respect to participation,

3. Which nurses work in what type of work schedules with respect to socio-demographic and family characteristics, and whether the perception of their fit of the work schedule with their private life differs,

4. Which nurses work in what type of work schedules with respect to well-being, motivation and sickness absence, and whether the type of work schedule is related to well-being, motivation and sickness absence,

5. Whether the work schedule fit with nurses' private life is a useful resource to enhance motivation and buffer the work-related external demands,

6. Whether nurses' work-related and home-related resources are useful to decrease sickness absence (besides home demands), and how they are related to sickness absence.

\section{Setting}

In this thesis, the target group is nurses working in residential elder care. This group has varying types of work schedules and high rates of health complaints and sickness absence. The present research focuses on nurses working shifts or irregular working hours in residential elder care. The homes for elder care participating in these studies accommodate clients with psycho-geriatric disorders and physical frailties. These particular organisations in the Netherlands were included because the nurses' work schedules are representative in that they reflect the diversity of work schedules of nurses working in both acute/short-term aged care as well as long-term aged care settings.

Although 'nurse' normally indicates the qualification level of a registered nurse, the current research uses this term for nurses working in residential elder care in the Netherlands. This includes registered nurses, enrolled nurses, licensed vocational or practical nurses, and nurse care helpers. In the Netherlands, although nurses working in residential elder care are comparable (with respect to qualification level) to nurses working in hospitals, home care, care for disabled people and mental health care, different psychosocial and physical demands are placed on them (128). The proportion of registered nurses working in residential elder care varies between European countries, with the Netherlands taking a lead in this respect (18) 


\section{Changes in Dutch Residential Elder Healthcare}

The current healthcare system in the Netherlands has undergone changes since the start of this research project that are relevant when interpreting the findings of the studies presented in this thesis. Before, residential elder care was mainly financed by the Exceptional Medical Expenses Act (Algemene Wet Bijzondere Ziektekosten, AWBZ), but since 2015, the Social Support Act (Wet maatschappelijke ondersteuning, WMO), the Chronic Care Act (Wel Langdurige Zorg, WLZ), the Healthcare Insurance Act (Zorgverzekeringswet, ZVW) and the new Youth Act (Jeugdwet, JW) were introduced to replace this act. Elder care has since then mainly been funded by the new Long-term Care Act and the Social Support Act. Because of these changes, only high-level care is provided by nursing homes. Care for elderly with low-level care needs is no longer provided intramural, but at their homes. Care homes have largely disappeared and extramural care has been replaced by informal care and home care. The new Long-term Care Act (WLZ), includes all care tasks for people with a heavy, long-term care need, such as frail older people, and people with a severe or chronic disability. Consequently, residential elder care has become a highly complex and intensive process and better qualified personnel is needed. At the same time, nursing homes faces major challenges in the coming years due to nursing shortages (129-130). Consequently, job demands and job content have changed substantially.

\section{Design}

The work presented here made use of two datasets that together help investigate the aims of this thesis, i.e. a cross-sectional dataset, and a longitudinal dataset (from the 'Time for care: Care for time' study).

The first study, presented in Chapter 2, is based on the cross-sectional dataset of 140 nurses working in residential elder care. The studies in Chapters $\mathbf{3}$ and $\mathbf{4}$ are based on the first wave of data from the longitudinal study entitled 'Time for care; care for Time' among a different nursing population of around 490 nurses working in residential elder care. The studies in Chapter 5 ( $\mathrm{n}=274$ nurses) and Chapter $\mathbf{6}$ ( $\mathrm{n}=370$ nurses) are based on the first and second wave of data obtained from the 'Time for care; care for Time' study. The study in Chapter 6 uses registered sick leave data one year after evaluations based on the first questionnaire.

\section{Outline of this thesis}

Chapter two presents a cross-sectional study focusing on the determinants of health, and on the development and validation of a new scale to measure 'the work schedule fit with private life' among nurses in residential elder care. This study tests whether the work schedule fit with private life mediates the relation between work and home characteristics on the one hand and health on the other.
In Chapter 3, using a larger dataset in a cross-sectional design, this study examines differences between nurses with respect to socio-demographic and family characteristics and perception of work schedule fit with their private life, to elucidate which nurses work in which type of work schedule. To achieve this, a new typology of work schedules is developed to assess the work schedules of nurses with shift work.

In Chapter 4, a dataset similar to that employed in Chapter 3 is used, but this study explores differences in participation in terms of well-being, motivation and sickness absence between nurses working in the different types of work schedules; an additional aim is to establish to what extent age might explain differences with respect to participation.

Chapter $\mathbf{5}$ investigates the role of personal and job resources. This study examines whether personal and job resources predict work engagement and emotional exhaustion, and whether interactions between personal resources/job resources and work schedule demands, predict work engagement and emotional exhaustion of nurses with shift work. This longitudinal study includes two waves of data collection, with a one-year follow-up, using self-report questionnaires among 247 nurses working shifts or irregular working hours in residential care for the elderly. Moderated structural equation modelling is conducted to analyse the interactions between personal and job resources, and work schedule demands.

Chapter 6 focuses on the effect of home demands/resources and job resources on sickness absence one year later, corrected for work-related external factors and the type of work schedule. In addition, it is examined how these variables are related and whether these relationships are mediated by health and motivation. Structural equation modelling analysis is performed on registered sick leave data to examine which characteristics predict registered sickness absence periods and duration one year later.

Finally, Chapter $\mathbf{7}$ provides a general discussion of the research presented in this thesis. 


\section{REFERENCES}

1. CBS. Bevolkingsprognose 2012-2060: Langer leven, langer werken [Central Statistical Office]. Voorburg/ Heerlen: Centraal Bureau voor de Statistiek (CBS)2012.

2. RIVM. Trends in Public Health. Bilthoven2017 [cited 2017 3-10-2017]; Available from: http://www. eengezondernederland.nl/en/English_version/Trends_in_Public_Health\#chapter-3.

3. Heerkens YF, Engels J, Kuiper C, Van der Gulden J, Oostendorp R. The use of the ICF to describe work related factors influencing the health of employees. Disabil Rehabil. 2004 Sep 2;26(17):1060-6.

4. Eurostat. Population structure and ageing. Luxembourg. : European Communion2015.

5. Kivimaki M, Forma P, Wikstrom J, Halmeenmaki T, Pentti J, Elovainio M, et al. Sickness absence as a risk marker of future disability pension: the 10-town study. Journal of Epidemiology and Community Health. [Research Support, Non-U.S. Gov't]. 2004 Aug;58(8):710-1.

6. Stapelfeldt CM, Nielsen CV, Andersen NT, Krane L, Borg V, Fleten N, et al. Sick leave patterns as predictors of disability pension or long-term sick leave: a 6.75 -year follow-up study in municipal eldercare workers. BMJ Open. 2014;4(2):e003941.

7. Kuoppala J, Lamminpaa A, Husman P. Work Health Promotion, Job Well-Being, and Sickness Absences-A Systematic Review and Meta-Analysis. Journal of Occupational and Environmental Medicine. [Review] 2008 Nov;50(11):1216-27.

8. Douwes M, Hooftman W, Kraan K, Steenbeek R, Venema A, De Vroome E, et al. Kwaliteit van de arbeid, effecten en maatregelen in Nederland. Leiden: TNO2014 Contract No.: ISBN 978-90-5986-455-9.

9. Putnik K. Creating new perspectives on work-home interface : a cross-cultural comparison of Malta, Serbia and the Netherlands. Maastricht :: Maastricht University; Maastricht University Library [host]; 2015.

10. Grinyer A, Singleton V. Sickness absence as risk-taking behaviour: A study of organisational and cultural factors in the public sector. Health, Risk \& Society. 2000;2(1):7-21.

11. Nielsen K, Albertsen K, Brenner SO, Smith-Hansen L, Roepsdorff C. Comparing working conditions and physical and psychological health complaints in four occupational groups working in female-dominated workplaces. International Archives of Occupational and Environmental Health. [Comparative Study Research Support, Non-U.S. Gov't]. 2009 Nov;82(10):1229-39.

12. Kingma M. Nurses on the Move: A Global Overview. Health Services Research. 2007;42(3p2):1281-98.

13. Sherman RO, Chiang-Hanisko L, Koszalinski R. The ageing nursing workforce: a global challenge. Journal of Nursing Management. [Editorial]. 2013 Oct;21(7):899-902.

14. WHO. The world health report 2006: working together for health: World Health Organization; 2006.

15. Kane RL, Shamliyan TA, Mueller C, Duval S, Wilt TJ. The association of registered nurse staffing levels and patient outcomes: systematic review and meta-analysis. Med Care. 2007 Dec;45(12):1195-204

16. Actiz. Working in elder care. Utrecht: Actiz; 2016 [cited 2016 29-02-2016].

17. Joldersma C, Laarman-Wierenga M, Brink M. AZWinfo Arbeid in Zorg en Welzijn 2015 [Work in Care and Social Welfare]. Zoetermeer: Panteia2016.

18. Hasselhorn H-M, Oginska H, Tackenberg P, Pokorski J, Estryn-Behar M, Camerino D, et al. NEXT - scientific results. Wuppertal: University of Wuppertal2005.

19. Onderzoeksprogramma arbeidsmarkt zorg en welzijn [Research Programm Work in Care and Social Welfare] [database on the Internet]. KIwa Caop. 2015. Available from: http://www.azwinfo.nl/.
20. Beemsterboer W, Stewart R, Groothoff J, Nijhuis F. A literature review on sick leave determinants (19842004). Int J Occup Med Environ Health. 2009;22(2):169-79

21. Eggink E, Oudijk D, Woittiez I. Zorgen voor zorg. Ramingen van de vraag naar personeel in de verpleging en verzorging tot 2030. Den Haag: Sociaal en Cultureel Planbureau2010.

22. EU. Commission staff working document on an action plan for the eu health workforce. Strasbourg: European Commission 2012

23. EU. Recruitment and Retention of the Health Workforce in Europe2015.

24. VenVN. Aan het werk voor een betere arbeidsmarkt in de zorg! . Utrecht: Berenschot2017.

25. CAOP. Arbeidsmarktagenda 2023 [Agenda Labour Market 2023] CNV, FNV, Actiz, Beter, NVZ, MBORaad, VWS.: CNV, FNV, Actiz, Beter, NVZ, MBO-Raad, VWS.; 2017; Available from: https://www. aanhetwerkvoorouderen.nl/timeline/arbeidsmarkt-en-opleidingen-zorgsector/.

26. Taylor E, Briner RB, Folkard S. Models of shiftwork and health: An examination of the influence of stress on shiftwork theory. Human Factors. 1997;39(1):67-82.

27. Härmä M. Workhours in relation to work stress, recovery and health. Scandinavian Journal of Work Environment \& Health. 2006 Dec;32(6):502-14.

28. De Rijk AE. Work Disability Theories: A Taxonomy for Researchers. In: Loisel P, Anema H, editors. Handbook of Work Disability: Springer Verlag; 2013.

29. Olsson K, Kandolin I, Kauppinen-Toropainen K. Stress and coping strategies of three-shift workers. Le Travail Humain. 1990;53(2):175-88.

30. Roelen CA, van Rhenen W, Schaufeli W, van der Klink J, Mageroy N, Moen B, et al. Mental and physical health-related functioning mediates between psychological job demands and sickness absence among nurses. Journal of Advanced Nursing. [Research Support, N.I.H., Extramural, Research Support, Non-U.S. Gov't, Validation Studies]. 2014 Aug;70(8):1780-92.

31. Hayes LJ, O'Brien-Pallas L, Duffield C, Shamian J, Buchan J, Hughes F, et al. Nurse turnover: a literature review - an update. International Journal of Nursing Studies. 2012 Jul;49(7):887-905.

32. Trybou J, Germonpre S, Janssens H, Casini A, Braeckman L, Bacquer DD, et al. Job-Related Stress and Sickness Absence Among Belgian Nurses: A Prospective Study. Journal of Nursing Scholarship. 2014;46(4):292-301.

33. Allebeck P, Mastekaasa A. Swedish Council on Technology Assessment in Health Care (SBU). Chapter 5. Risk factors for sick leave - general studies. Scand J Public Health Suppl. [Review]. 2004;63:49-108.

34. Clausen T, Nielsen K, Carneiro IG, Borg V. Job demands, job resources and long-term sickness absence in the Danish eldercare services: a prospective analysis of register-based outcomes. Journal of Advanced Nursing. [Research Support, Non-U.S. Gov't]. 2012 Jan;68(1):127-36

35. Eriksen W, Bruusgaard D, Knardahl S. Work factors as predictors of sickness absence: a three month prospective study of nurses' aides. Occupational and Environmental Medicine. 2003 April 1, 2003;60(4):271-8.

36. Bakker AB, Demerouti E, de Boer $E$, Schaufeli WB. Job demands and job resources as predictors of absence duration and frequency. Journal of Vocational Behavior. 2003;62(2):341-56.

37. Labriola $\mathrm{M}$, Lund $\mathrm{T}$, Burr $\mathrm{H}$. Prospective study of physical and psychosocial risk factors for sickness absence. Occupational Medicine. 2006 0ct;56(7):469-74.

38. Nielsen ML, Rugulies R, Smith-Hansen L, Christensen KB, Kristensen TS. Psychosocial work environment and registered absence from work: Estimating the etiologic fraction. American Journal of Industria Medicine. 2006;49(3):187-96 
39. Houtman I, de Jonge J. De epidemiologie van werkgerelateerde psychische aandoeningen en klachten [The epidemiology of work related psychological disorders and complaints]. In: Schaufeli W, Bakker A editors. De psychologie van arbeid en gezondheid. Houten: Bohn Stafleu van Loghum; 2003. p. 265-80.

40. Karasek RA, Theorell T. Healthy Work: Stress, Productivity and the Reconstruction of Working Life. New York: Basic Books; 1990

41. Van der Doef M, Maes S. The Job Demand-Control (-Support) Model and psychological well-being: A review of 20 years of empirical research. Work \& Stress. 1999;13(2):87-114.

42. Bakker AB, Demerouti E. The Job Demands-Resources model: State of the art. Journal of Managerial Psychology. 2007;22(3):309-28.

43. Lund T, Labriola M. Sickness absence in Denmark - research, results, and reflections. SJWEH Supplements. [journal article]. 2009 December 0(7):5-14.

44. de Jonge J, Le Blanc PM, Peeters MCW, Noordam H. Emotional job demands and the role of matching job resources: a cross-sectional survey study among health care workers. Int J Nurs Stud. 2008 Oct;45(10):1460-9.

45. Rosa R, Colligan M. Plain language about shiftwork. Cincinnati, $\mathrm{OH}$ : Department of Health and Human Services, Public Health Service, Centers for Disease Control and Prevention, National Institute for Occupational Safety and Health, Division of Biomedical and Behavioral Science, (NIOSH); 1997.

46. Merkus SL, van Drongelen $\mathrm{A}$, Holte KA, Labriola M, Lund $\mathrm{T}$, van Mechelen $\mathrm{W}$, et al. The association between shift work and sick leave: a systematic review. Occupational and Environmental Medicine. [Research Support, Non-U.S. Gov't Review]. 2012 Oct;69(10):701-12.

47. Knutsson A. Methodological Aspects of Shift-Work Research. Chronobiology International: The Journal of Biological and Medical Rhythm Research. 2004;21(6):1037 - 47.

48. Åkerstedt T, Kecklund G. The future of work hours--the European view. Industrial Health. 2005 Jan;43(1):80-4.

49. Haanstra-Veldhuis V, De Zwart BCH. Flexibilisering en werkbeleving in de vvt-sector: onderzoek onder medewerkers in de verzorging \& verpleging en thuiszorg. 2013.

50. Evers G, Jettinghoff K, Van Essen G. Werknemersenquête Zorg en WJK 2015 uitgesplitst naar VVT2016.

51. Eurofound. Fifth European Working Conditions Survey. Luxembourg: European Foundation for the Improvement of Living and Working Conditions2012.

52. Nabe-Nielsen K, Kecklund G, Ingre M, Skotte J, Diderichsen F, Garde AH. The importance of individual preferences when evaluating the associations between working hours and indicators of health and well-being. Applied Ergonomics. 2010;41(6):779-86.

53. Van de Ven HA, Klein Hesselink J, Bultmann U, de Boer MR, de Looze MP, van der Klink JJ, et al. Individual and work-related predictors of work outcomes related to sustainable employment among male shift and day workers. Scandinavian Journal of Work, Environment \& Health. 2013 Oct 16.

54. Lipscomb JA, Trinkoff AM, Geiger-Brown J, Brady B. Work-schedule characteristics and reported musculoskeletal disorders of registered nurses. Scand J Work Environ Health. 2002 Dec;28(6):394-40

55. Tucker $P$, Folkard $S$. Working time, health, and safety : A research synthesis paper. Geneva: International Labour Office2012.

56. Costa G. The impact of shift and night work on health. Applied Ergonomics. 1996 Feb;27(1):9-16.

57. Costa G. Shift work and occupational medicine: an overview. Occup Med (Lond). 2003 March 1, 2003;53(2):83-8.

58. Harrington JM. Health effects of shift work and extended hours of work. Occupational and Environmental Medicine. 2001 January 1, 2001;58(1):68-72.
59. Knutsson A. Health disorders of shift workers. Occup Med (Lond). 2003 March 1, 2003:53(2):103-8.

60. Smith M, Eastman C. Shift work: health, performance and safety problems, traditional countermeasures, and innovative management strategies to reduce circadian misalignment. Nature and Science of Sleep. 2012;4:111-32.

61. Muecke S. Effects of rotating night shifts: literature review. Journal of Advanced Nursing. 2005 May;50(4):433-9.

62. Nabe-Nielsen K, Tüchsen F, Christensen KB, Garde AH, Diderichsen F. Differences between day and nonday workers in exposure to physical and psychosocial work factors in the Danish eldercare sector. Scandinavian Journal of Work, Environment \& Health. 2009:35(1):48-55.

63. Straif K, Baan R, Grosse Y, Secretan B, Ghissassi FE, Bouvard V, et al. Carcinogenicity of shift-work painting, and fire-fighting. The Lancet Oncology. 2007;8(12):1065-6.

64. Barton J, Spelten E, Totterdell P, Smith L, Folkard S, Costa G. The Standard Shiftwork Index: a battery of questionnaires for assessing shiftwork-related problems. Work \& Stress. 1995 1995/01/01;9(1):4-30

65. Demerouti E, Bakker AB, Nachreiner F, Schaufeli WB. The job demands-resources model of burnout. Appl Psychol. 2001 Jun; 86(3):499-512

66. Bourbonnais R, Vinet A, Vézina M, Gingras S. Certified sick leave as a non-specific morbidity indicator: a case-referent study among nurses. Br J Ind Med. 1992 Oct;49(10):673-8.

67. Tuchsen F, Christensen KB, Nabe-Nielsen K, Lund T. Does evening work predict sickness absence among female carers of the elderly? Scand J Work Environ Health. 2008 Dec;34(6):483-6.

68. Flinkman M, Laine M, Leino-Kilpi H, Hasselhorn HM, Salanterä S. Explaining young registered Finnish nurses' intention to leave the profession: A questionnaire survey. International Journal of Nursing Studies. 2008;45(5):727-39

69. AZWinfo. Arbeid in Zorg en Welzijn 2010. Zoetermeer: Panteia2011.

70. Estryn-Behar M, van der Heijden BIJM, Fry C, Hasselhorn H-M. Longitudinal analysis of personal and work-related factors associated with turnover among nurses. Nursing Research. 2010;59(3):166-77.

71. McVicar A. Workplace stress in nursing: a literature review. Journal of Advanced Nursing. 2003 Dec;44(6):633-42.

72. Griffiths P, Dall'Ora C, Simon M, Ball J, Lindqvist R, Rafferty AM, et al. Nurses' shift length and overtime working in 12 European countries: the association with perceived quality of care and patient safety. Med Care. 2014 Nov;52(11):975-81.

73. Jettinghof K, Van Hassel D, Joldersma C. AZWinfo Arbeid in Zorg en Welzijn 2016 [Work in Care and Social Welfare]. Zoetermeer: Panteia2017.

74. Ten Brummelhuis LL, ter Hoeven $\mathrm{CL}$, de Jong MDT, Peper B. Exploring the linkage between the home domain and absence from work: Health, motivation, or both? Journal of Organizational Behavior 2013;34(3):273-90.

75. Ten Brummelhuis $L L, B a k k e r A B$. A resource perspective on the work-home interface: the work-home resources model. Am Psychol. 2012 Oct; 67(7):545-56

76. Portegijs W, Cloin M, Roodsaz R, Olsthoorn M. Lekker vrij? Vrije tijd, tijdsdruk en de relatie met de arbeidsduur van vrouwen. Den Haag: Sociaal en Cultureel Planbureau2016. Report No.: ISBN 97890 37707762.

77. Demir A, Ulusoy M, Ulusoy MF. Investigation of factors influencing burnout levels in the professional and private lives of nurses. International Journal of Nursing Studies. 2003;40(8):807-27. 
78. Peeters MCW, Montgomery AJ, Bakker AB, Schaufeli WB. Balancing Work and Home: How Job and Home Demands Are Related to Burnout. International Journal of Stress Management. 2005;12(1):43-61.

79. Staland-Nyman C, Alexanderson K, Hensing G. Associations between strain in domestic work and self-rated health: A study of employed women in Sweden. Scand J Public Health. 2008 January 1, 2008;36(1):21-7.

80. Pisarski A, Bohle P, Callan VJ. Effects of coping strategies, social support and work-nonwork conflict on shift worker's health. Scand J Work Environ Health. 1998;24:141-5.

81. Simpson MR. Engagement at work: a review of the literature. Int J Nurs Stud. 2009 Jul;46(7):1012-24.

82. Hobfoll SE, Shirom A. Conservation of resources theory: Applications to stress and management in the workplace. In: Golembiewski RT, editor. Handbook of organizational behavior (2nd ed, rev ed and exped). New York, NY US: Marcel Dekker; 2001. p. 57-80.

83. Hobfoll SE. Social and psychological resources and adaptation. Review of General Psychology. 2002;6(4):307-24.

84. Gorgievski MJ, Hobfoll SE. Work can burn us out and fire us up; Conservation of Resources in Burnout and Engagement. In: Halbesleben JRB, editor. Handbook of stress and burnout in health care. Hauppage, new York: Nova Publishers; 2008. p. pp. 7-22.

85. Winwood PC, Winefield AH, Lushington K. Work-related fatigue and recovery: the contribution of age, domestic responsibilities and shiftwork. Journal of Advanced Nursing. 2006;56(4):438-49.

86. Demerouti $E$, Bakker $A B$, Voydanoff P. Does home life interfere with or facilitate job performance? European Journal of Work and Organizational Psychology. 2010;19(2):128-49.

87. Greenhaus JH, Powell GN. When Work and Family Are Allies: A Theory of Work-Family Enrichment The Academy of Management Review. 2006;31(1):72-92.

88. Schaufeli WB, Taris TW. A Critical Review of the Job Demands-Resources Model: Implications for Improving Work and Health. 2014:43-68.

89. Caruso CC, Bushnell T, Eggerth D, Heitmann A, Kojola B, Newman K, et al. Long working hours, safety, and health: toward a National Research Agenda. Am J Ind Med. 2006 Nov;49(11):930-42.

90. Krausz M, Sagie A, Bidermann Y. Actual and Preferred Work Schedules and Scheduling Control as Determinants of Job-Related Attitudes. Journal of Vocational Behavior. 2000;56(1):1-11.

91. Pryce J, Albertsen K, Nielsen K. Evaluation of an open-rota system in a Danish psychiatric hospital: a mechanism for improving job satisfaction and work-life balance. Journal of Nursing Management. 2006;14(4):282-8.

92. Galatsch M, Li J, Derycke H, Muller BH, Hasselhorn HM. Effects of requested, forced and denied shift schedule change on work ability and health of nurses in Europe -Results from the European NEXT-Study. BMC Public Health. 2013 Dec 5;13(1):1137.

93. Schaufeli WB, Bakker AB, Van Rhenen W. How changes in job demands and resources predict burnout work engagement, and sickness absenteeism. Journal of Organizational Behavior. 2009;30(7):893-917.

94. Nijp HH, Beckers DG, Geurts SA, Tucker P, Kompier MA. Systematic review on the association between employee worktime control and work-non-work balance, health and well-being, and job-related outcomes. Scandinavian Journal of Work, Environment \& Health. [Research Support, Non-U.S. Gov't Review]. 2012 Jul;38(4):299-313.

95. Ala-Mursula, Vahtera J, Linna A, Pentti J, Kivimäki M. Employee worktime control moderates the effects of job strain and effort-reward imbalance on sickness absence: the 10-town study. Journal of Epidemiology and Community Health. 2005 October 2005;59(10):851-7.
96. Schmieder RA, Smith CS. Moderating effects of social support in shiftworking and non-shiftworking nurses. Work \& Stress. 1996 1996/04/01;10(2):128-40.

97. Pisarski A, Brook C, Bohle P, Gallois C, Watson B, Winch S. Extending a Model of Shift-Work Tolerance. Chronobiology International. 2006;23(6):1363-77.

98. Sundin L, Hochwälder J, Bildt C, Lisspers J. The relationship between different work-related sources of social support and burnout among registered and assistant nurses in Sweden: A questionnaire survey. International Journal of Nursing Studies. 2007;44(5):758-69.

99. Halbesleben JR. Sources of social support and burnout: a meta-analytic test of the conservation of resources model. J Appl Psychol. [Meta-Analysis]. 2006 Sep;91(5):1134-45.

100. Wilson JL. The impact of shift patterns on healthcare professionals. Journal of Nursing Management. 2002;10(4):211-9.

101. Hobfoll SE, Johnson RJ, Ennis N, Jackson AP. Resource loss, resource gain, and emotional outcomes among inner city women. Journal of Personality and Social Psychology. 2003;84(3):632-43.

102. Beutell NJ. Work schedule, work schedule control and satisfaction in relation to work-family conflict, work-family synergy, and domain satisfaction. Career Development International. 2010;15 (5):501 - 18

103. Peeters $\mathrm{MA}$, Rutte $\mathrm{CG}$. Time management behavior as a moderator for the job demand-control interaction. Journal of Occupational Health Psychology. [Review]. 2005 Jan;10(1):64-75.

104. Tucker P, Knowles SR. Review of studies that have used the Standard Shiftwork Index: evidence for the underlying model of shiftwork and health. Applied ergonomics. 2008 Sep;39(5):550-64.

105. Puttonen S, Härmä M, Hublin C. Shift work and cardiovascular disease - pathways from circadian stress to morbidity. Scand J Work Environ Health. 2010 Mar;36(2):96-108.

106. Saksvik IB, Bjorvatn B, Hetland H, Sandal GM, Pallesen S. Individual differences in tolerance to shift work - A systematic review. Sleep Med Rev. 2010 Sep 16.

107. Weigl M, Hornung S, Parker SK, Petru R, Glaser J, Angerer P. Work engagement accumulation of task, social, personal resources: A three-wave structural equation model. Journal of Vocational Behavior. 2010;77(1):140-53

108. van Rhenen W, Schaufeli WB, van Dijk FJ, Blonk RW. Coping and sickness absence. International Archives of Occupational and Environmental Health. 2008 Feb;81(4):461-72.

109. De Rijk AE, Le Blanc PM, Schaufeli WB, De Jonge J. Active coping and need for control as moderators of the job demand-control model: Effects on burnout. Journal of Occupational \& Organizational Psychology. [Article]. 1998;71(1):1-18

110. Garrosa E, Rainho C, Moreno-Jimenez B, Monteiro MJ. The relationship between job stressors, hardy personality, coping resources and burnout in a sample of nurses: a correlational study at two time points. International Journal of Nursing Studies. 2010 Feb;47(2):205-15.

111. Sasaki M, Kitaoka-Higashiguchi K, Morikawa Y, Nakagawa H. Relationship between stress coping and burnout in Japanese hospital nurses. Journal of Nursing Management. 2009;17(3):359-65.

112. Parkes KR. Coping, negative affectivity, and the work environment: Additive and interactive predictors of mental health. Journal of Applied Psychology. 1990;75(4):399-409.

113. Härmä M, Ropponen A, Hakola T, Koskinen A, Vanttola P, Puttonen S, et al. Developing register-based measures for assessment of working time patterns for epidemiologic studies. Scandinavian Journal of Work, Environment \& Health. [Research Support, N.I.H., Extramural, Research Support, Non-U.S. Gov't] 2015 May 1;41(3):268-79. 
114. Caroly S. How police officers and nurses regulate combined domestic and paid workloads to manage schedules: a gender analysis. Work. 2011;40 Suppl 1:S71-82.

115. CBS/TNO. Nationale Enquête Arbeidsomstandigheden 2014. Leiden: TNO; 2016; Available from: http:// www.monitorarbeid.tno.nl/cijfers/nea.

116. Clarkberg M, Moen P. Understanding the Time-Squeeze: Married Couples' Preferred and Actual WorkHour Strategies. American Behavioral Scientist. 2001 March 1, 2001;44(7):1115-36.

117. Taht K, Mills M. Nonstandard Work Schedules, Couple Desynchronization, and Parent-Child Interaction: A Mixed-Methods Analysis. Journal of Family Issues. [Article]. 2012 Aug;33(8):1054-87.

118. Fagan C, Lyonette $C$, Smith $M$, Saldaña-Tejeda $A$. The influence of working time arrangements on work-life integration or 'balance': A review of the international evidence. Geneva: International Labour Office2012.

119. Ruggiero JS, Pezzino JM. Nurses' perceptions of the advantages and disadvantages of their shift and work schedules. The Journal of nursing administration. 2006 0ct;36(10):450-3.

120. Presser HB. Job, family, and gender: determinants of nonstandard work schedules among employed Americans in 1991. Demography. 1995 Nov;32(4):577-98.

121. Boot CR, Koppes LL, van den Bossche SN, Anema JR, van der Beek AJ. Relation between perceived health and sick leave in employees with a chronic illness. J Occup Rehabil. 2011 Jun;21(2):211-9.

122. De Raeve L, Kant I, Jansen NW, Vasse RM, van den Brandt PA. Changes in mental health as a predictor of changes in working time arrangements and occupational mobility: results from a prospective cohort study. Journal of Psychosomatic Research. 2009 Feb;66(2):137-45.

123. Barthe B, Messing K, Abbas L. Strategies used by women workers to reconcile family responsibilities with atypical work schedules in the service sector. Work. [Research Support, Non-U.S. Gov't]. 2011;40 Suppl 1:S47-58.

124. Holtom BC, Lee TW, Tidd ST. The relationship between work status congruence and work-related attitudes and behaviors. Journal of Applied Psychology. 2002;87(5):903-15.

125. Sturman MC, Walsh K. Strengthening the employment relationship: The effects of work-hours fit on key employee attitudes. Journal of Organizational Behavior. 2014;35(6):762-84.

126. Heerkens YF, de Brouwer CPM, Engels JA, van der Gulden JWJ, Kant I. Elaboration of the contextual factors of the ICF for Occupational Health Care. Work. 2017;57(2):187-204.

127. De Jonge J, Le Blanc P, Schaufeli WB. Theoretische modellen over werkstress [Theoretical job stress models]. In: Schaufeli W, Bakker A, editors. De psychologie van arbeid en gezondheid. Houten: Bohn Stafleu van Loghum; 2013. p. 23-46.

128. Simon M, Tackenberg P, Nienhaus A, Estryn-Behar M, Conway PM, Hasselhorn HM. Back or neck-painrelated disability of nursing staff in hospitals, nursing homes and home care in seven countries--results from the European NEXT-Study. International Journal of Nursing Studies. [Comparative Study Research Support, Non-U.S. Gov'tt. 2008 Jan;45(1):24-34.

129. Kalkhoven F, van der Aalst M. Tekorten in de zorg leiden tot problemen, maar bieden ook kansen [Nursing shortages lead to problems, but also offer opportunities]. Sociaal Bestek. [journal article]. 2018 April 01;80(2):48-9.

130. VenVN. Personeelstekorten in de zorg. Oplossingen van de werkvloer [Staff shortages in health care. Solutions from the workfloor]. Utrecht: V\&VN; 2017 [cited 2018 01-06]; Available from: https://www. venvn.nl/oplossingenvandewerkvloer. 


\section{ABSTRACT}

Aim: This paper is a report of a study conducted to determine if satisfaction with irregular working hours that are a form of shiftwork operates as a mediator between work and home characteristics and health problems.

Background: Shiftwork contributes to health problems, decreased well-being and poorer health habits. It also affects employees' decisions to leave the healthcare sector. Although many nurses voluntarily work shifts, there have been few studies of their satisfaction with irregular working hours when these are a form of shiftwork.

Methods: A survey was carried out with 144 nurses working in three nursing homes and one care home in the Netherlands. Questionnaires were distributed in 2003 to 233 nurses who worked shifts (response rate 60\%). The questionnaire contained items on work and home characteristics, satisfaction with irregular working hours that are a form of shiftwork and health. A new scale to measure satisfaction with irregular working hours was constructed.

Results: All work characteristics, but no home characteristics, were associated with satisfaction with irregular working hours. The work characteristics "job demands" and the home characteristics "autonomy at home" and "home demands" were associated with health. Satisfaction with irregular working hours did not mediate between work/home characteristics and health. Those reporting more social support, lower job demands and more job autonomy were more satisfied with their irregular working times that were a form of shiftwork.

Conclusions: Satisfaction with irregular working hours is a useful construct that requires further longitudinal study. The results also underline the importance of considering home characteristics when predicting health outcomes.

\section{INTRODUCTION}

Research that offers insight into how nursing can become more attractive to the current nursing population and to new nursing students is imperative. Shortages of nurses will soon become a major problem in the Netherlands (1), as it already is around the world (2-4). These shortages are caused by the increasing demand for healthcare services because of 1) changing demographics, 2) longer life expectancy and 3) increases in the prevalence of chronic diseases. The shortage is exacerbated by high turnover and sickness absenteeism in the nursing profession.

The problem of nursing shortage is most prominent in residential elder care, such as nursing homes delivering intensive care and rehabilitative services and care homes providing meals and personal care. These have the highest sickness absenteeism levels in the Dutch healthcare sector (5). Additionally, shortages are expected to increase even further as a result of general decreases in the size of the labour force due to the outflow of older employees. About one in every four students leaving secondary school will have to work in the healthcare sector to compensate for this shortage, while at this moment the inflow of new students is decreasing (1). Nursing homes and care homes should thus focus on how to make the jobs more attractive, both to increase the inflow and to decrease turnover and sickness absence. An important way to do this is to improve nurses' health.

In this paper, we distinguish three factors that may cause problems regarding nursing health and thus require improvement: shiftwork, the specific job characteristics of nursing, and the combination of work and care duties. Nurses' shiftwork in the Netherlands is characterized by irregular working hours. We assume that nursing professionals will vary in their satisfaction with having these irregular working hours.

We assume also that job characteristics and the way in which working and caring is combined affect their satisfaction with their shiftwork.

\section{BACKGROUND}

Shiftwork, job characteristics and combining working and caring.

The first factor that may negatively influence nurses' health is shiftwork. It is of one of the profession's oldest problems and has been shown to contribute to influence the health of nurses $(6-8)$ and to absenteeism $(9,10)$. Shiftwork causes stress to nurses and thereby influences their health, well-being and lifestyles (11). Furthermore, because of these effects, nurses working shifts also have been found to be at greater risk for disability than those working regular hours (12). With regard to the nurses' social habits, shiftwork can reduce social contacts and decrease involvement in various social organizations (13). Shiftwork is high on the list of factors that contribute to leaving the nursing profession $(14,15)$. Nevertheless, many nurses voluntarily do shiftwork. Some willingly 
accept shiftwork and there are even some who appreciate it (16). Reported advantages of shiftwork include having a weekday off during a normal work week, being able to attend school activities, and having the flexibility that enables one to care for family and fulfil family responsibilities more easily (17). It is thus expected that whether one is satisfied with shiftwork will not only depend on the work situation but also on characteristics of the home situation.

Definitions of shiftwork differ (18). It is normally defined as working outside the normal daytime hours (19). Shiftwork among nurses in the Netherlands involves continuous, rotating systems in which nurses change from one shift to another, including nightshifts, and working in weekends and can be unpredictable (20). Furthermore, the speed and direction of rotation can differ and their weekly work hours can vary. This irregularity is assumed to have the most impact on wellbeing and satisfaction with shiftwork $(21,22)$. In line with the Dutch designation, in our study we defined this form of shiftwork as irregular working hours and the study therefore focuses on satisfaction with irregular working hours (SIW).

A second factor that affects nurses' reactions to their work is its specific job characteristics. Nursing is strenuous work, and occupational stress is prevalent among nurses. In fact, 30-40\% of absenteeism has been estimated to be work-related (23). Additionally, about half of healthcare personnel indicated their long-term sickness absence to be work-related in a study by Van den Windt et al. (24). In 2006, $46 \%$ of the nurses working in nursing and care homes reported that job demands had a negative influence on their job performance (25). Furthermore, research has shown that low perceived job autonomy and high perceived job demands, in combination with insufficient social support, are related to stress and health problems among nurses (26).

A third factor that determines nurses' health is the combination of work and care duties. Scientific interest in this factor is recent due to the increased labour participation of women and changes that have blurred the boundaries between work and private life $(27,28)$. Researchers have become aware of the fact that nurses may experience stress not only because of their work, but also because of their home situation $(29,30)$. Many tasks and little social support (e.g. from their partner) at home have been found to be associated with health problems (31). However, at the same time, being part of a family also appears to play a role in preventing the development of health problems (32)

\section{Research mode}

Given that this form of shiftwork, with irregular working hours, is not the only cause of health problems in nursing and it is impossible to abolish it, we must focus on determining the conditions at home and at work that can keep nurses relatively satisfied with irregular working hours and consequently keep them healthy. To date, research on the associations between work characteristics, home characteristics, SIW and health is limited. For this reason, we chose to focus on the mediating role of nurses' SIW in the relationship between work and home characteristics on the one hand and nurses' health on the other hand.

Several theoretical frameworks relate work characteristics with psychological and physical outcome variables. One of the most influential models is the Job Demand-Control Support (JDCS) model $(33,34)$. In our context, it is important to use a validated model to make explicit the role of a new concept. According to this model, if the perceived demands at work are relatively low and there is sufficient autonomy and social support, positive health outcomes can be expected.

In our model, we included demands, autonomy and social support at home (35). We further hypothesized that nurses who evaluated their SIW relatively positively would also report better health than those who considered their shiftwork to be taxing. This is in line with findings by Krausz et al. (36). Furthermore, SIW was assumed to mediate the relationship between work and home characteristics on the one hand, and health on the other. This reasoning corresponds with a vast amount of research on job stress, job-related attitudes and health (37-39). In most of these stress theories, the stress process is seen as a causal chain of stress and strain. First, objective stressors will influence subjective stressors. Second, these stressors will influence job satisfaction and subsequently psychological and physical health (40). Thus, it can be expected that satisfaction with certain aspect of the job mediates the relationship between stressors and health. Our model is presented in Figure 1.

\section{THE STUDY}

\section{Aim}

The aim of the study was to determine if satisfaction with irregular working hours that are a form of shiftwork operates as a mediator between work and home characteristics and health problems. We posed the following research questions:

1. What are the relationships between work and home characteristics with satisfaction with irregular working hours?

2. What are the relationships between work and home characteristics with health?

3. What is the relationship between satisfaction with irregular working hours with health?

4. Does satisfaction with irregular working hours act as a mediator between work and home characteristics on the one hand and health on the other?

In Figure 1, the relationships that are referred to in the research questions are numbered. 


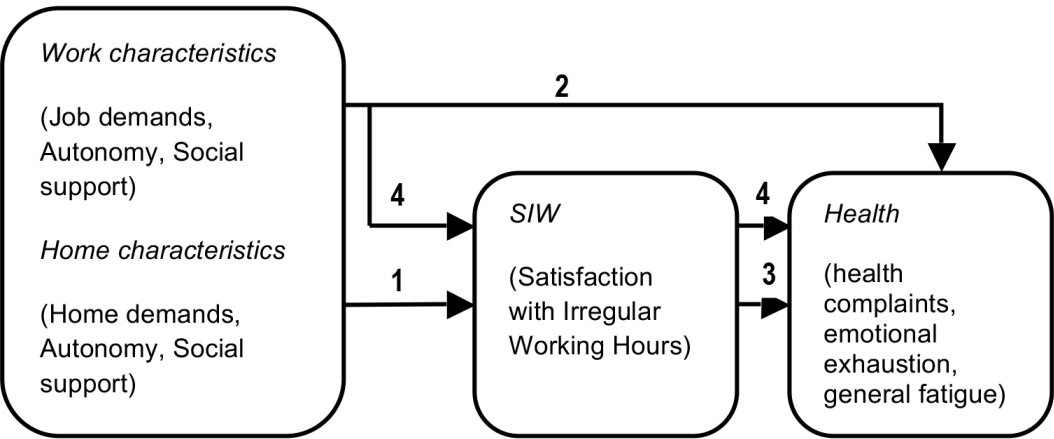

Figure 1: The research model

\section{Design}

The study had a cross-sectional survey design and data were collected in 2003.

\section{Participants}

The study involved all nurses working shifts in one care home and three nursing homes in the Netherlands. These four homes accommodate a combination of approximately 350 psychogeriatric and physically frail clients and belong to the same organisation for elder care.

All nurses working shifts and who had been employed in their organisation for at least three months were asked to participate in the study. This latter criterion was included as it was thought that employees working less than three months at an institution might not yet be totally familiar with their new work situation and therefore unable to convey their SIW. Of all nurses that met the inclusion criteria ( $\mathrm{N}=233), 140$ returned the questionnaire (response rate of $60 \%$ ).

\section{Data collection}

Data were collected using a questionnaire assessing demographic variables, work characteristics, home characteristics, SIW and health variables. They were asked to return the questionnaire within two weeks. Two weeks after the initial distribution of the questionnaires, a reminder letter was sent to all participants.

\section{Measures}

Demographic variables included age, work location, educational level as distinguished by 5 levels (care assistant level 1, care helper level 2, care worker level 3, nurse level 4 implying a degree at vocational education level, nurse level 5 implying a bachelor degree at an university of applied sciences), work history and taking care of children (yes or no).

Work characteristics were selected from the JDCS model (33). Job demands were measured using an eight-item scale (41) with a 5-point response scale that ranges from 'never' to 'always'. The scale contains a range of quantitative and qualitative items concerning the work situation. (Item example: 'In the organization where I work, too much work has to be done'). Internal consistency estimated by Cronbach's a is 0.90 . Job autonomy refers to the worker's ability and opportunities to determine a various task elements, such as the method of working, the pace of work and the work goals. This was assessed with the Maastricht Autonomy Questionnaire (MAQ; 41), a 10- item scale with a 5-point response scale ranging from 'very little' to 'very much'(Item example: 'My work allows me to determine my own working method') (Cronbach's $\alpha=0.86$ ). Social support refers to the worker's perceived social support from supervisors and colleagues. This was measured using a 10-item scale derived from a Dutch questionnaire for organisational stress (VOS-D; 42). This scale uses a 4-point response scale that ranges from 'never' to 'always' (Item example: 'If you have problems at work, can you discuss them with your colleagues?') (Cronbach's $\alpha=0.82$ ).

Home Characteristics were operationalised similarly to the operationalisation of work characteristics (35). Home demands were measured using a 7-item scale with a 5 -point response scale ranging from 'once a month' to 'seven times a week' (35). This scale measures quantitative demands at home (Item example: 'How many times a week do you usually have to clean the house?') (Cronbach's = 0.87). Autonomy at home was measured with only one item ('Is it possible to find someone to take over work and home tasks when you cannot manage? This scale uses a 4-point response scale that ranges from 'never' to 'always' (35). Social support at home was measured with two items ('How often does your partner, family or friends pay attention to your feelings and problems regarding your work?' and 'How often does your partner, family or friends pay attention to your job?'). This scale has a 4-point response scale that ranges from 'never' to 'always' (35) (Cronbach's $\alpha=0.74$ ).

Development of Satisfaction with Irregular Working Hours (SIW) scale

SIW was measured using a newly-developed scale (see appendix 1). As earlier described, irregularity is emphasized because this matches the type of shiftwork in our population. SIW refers to the extent to which nurses are satisfied with their irregular work schedules, particularly in the context of their leisure time, family situation, social circumstances, sleep and work-leisure time balance $(6,11,43)$. We developed the scale as follows (44):

1. We first conducted a literature review to detect relevant domains in working shifts. 2. We conducted semi-structured interviews $(\mathrm{N}=5)$ with nurses who work shifts to identify categories of problems related to working shifts.

3. Based on the results of step 1 and step 2 a scale was developed, consisting of 15 items.

4. To improve face and content validity, the scale was evaluated for relevance, clarity and readability of the items by a panel of four experts with experience of scale development and with nurses who worked shifts. Content validity of the scale was regarded as satisfactory by both experts and nurses. 5. Based on the results of step 4, the scale was adjusted and shortened to 13 items. A 5-point response scale ranging from 1 'entirely dissatisfied' to 5 'entirely satisfied' was used. 
6. In the final step, to investigate the psychometric properties reliability and factor analyses were conducted. Internal consistency estimated by Cronbach's $\alpha$ in this study was 0.89 , and the average inter-item correlations was 0.39 . Explorative factor analysis using an eigenvalue greater than 1.0 as the criterion showed a 2 -factor structure explaining $54 \%$ of the total variance. However, one item scaled on both factors. The separate factor did not reflect clearly different concepts. The scale as a total had a high internal reliability. We therefore considered the SIW scale to be one-dimensional.

Health variables were measured using three scales. First, psychosomatic health complaints were measured with a 13-item version of a Dutch perceived health questionnaire (VOEG (Vragenlijst Onderzoek Ervaren Gezondheid [Perceived Health Questionnaire]) developed by Dirken (45). The VOEG contains items that ask if the respondent suffers from a range of psychosomatic complaints, such as headaches and backache. Each item is scored with either 'yes' or 'no'. A higher sum score reflects the presence of more psychosomatic complaints. Internal consistency estimated by Cronbach's $a$ is $0.75-0.93$.

General fatigue was measured with the Multidimensional Fatigue Inventory (MFI)(46). This scale contains four items that are scored on a 5-point scale ranging from 'yes, that is true' to 'no, that is not true' (Item example: 'I feel very tired'). Internal consistency estimated by Cronbach's $\alpha=0.86$.

Emotional exhaustion was measured using the Dutch version of the Maslach Burnout Inventory (47). This instrument is particularly suitable for use in human services professions like nursing. Moreover, emotional exhaustion is the most characteristic burnout dimension. The Maslach Scale contains five items that are scored on a 7-point response scale from 'never' to 'always' (Item example: 'Working all day is really a strain for me'). Internal consistency estimated by Cronbach's $\mathrm{a}=0.74-0.88$

\section{Ethical considerations}

The study was approved by the management of the organisation involved. The research procedure was communicated to the nurses through an institutional newsletter and an individual letter. Return of a completed questionnaire was taken to imply consent.

\section{Data analysis}

Data were analysed using the Statistical Package for Social Science (SPSS) version 12.0. Descriptive statistics were computed for all variables. The internal consistency of the scale was determined by Cronbach's alpha reliabilities. Inferential statistics were used to address the research questions. Scales were created by averaging the items. To investigate the relationships between work characteristics, home characteristics, SIW and health, multiple regression analyses were performed. Variables to be controlled for were age, educational level, work location, work history and childcare. In these analyses, the level of statistical significance was set at $p<.05$. The variance, the change in variance and standardized beta's were computed.
To determine whether SIW acts as a mediator in the relationships between work and home characteristics on the one hand and health on the other, multiple regression analyses were performed. It is important to note that, in order to establish mediation, the following four conditions have to be met $(48,49)$ :

1. Work and home characteristics must be associated with the health variables. Regression analyses were therefore performed with health variables as the dependent variables and work and home characteristics as independent variables. In these analyses, we corrected for the potential confounding variables (for age, educational level, work location, work history and childcare).

2. Work and home characteristics must be associated with SIW. We therefore performed regression analyses with SIW as the dependent variable and work and home characteristics as independent variables. Here too, we corrected for the potential confounding variables.

3. SIW must be associated with health. To answer the third research question, regression analyses were performed with all health variables as dependent variables and SIW as the independent variable corrected only for the confounding variables. Subsequently, hierarchical regression analyses were applied on all health variables with first entering background variables and SIW and secondly entering work and home characteristics. Again, we corrected for the confounding variables. 4. If all these three conditions are met there is a possible mediation effect. To see if there is a partially or a complete mediation effect of SIW, we had to determine whether or not the associations between work and home characteristics and the health variables (partially or completely) disappear when entering SIW. Steps 3 and 4 are estimated in the same equation. 


\section{RESULTS}

\section{Respondent demographics}

Table 1: Respondent demographics ( $\mathrm{N}=140)$

\begin{tabular}{|c|c|c|}
\hline \multicolumn{2}{|l|}{ Descriptive } & Values \\
\hline Women & 133 & $(95 \%)$ \\
\hline Working in nursing home & 120 & $(86 \%)$ \\
\hline $15-25$ years & 21 & $(15 \%)$ \\
\hline 26-35 years & 35 & $(25 \%)$ \\
\hline $36-45$ years & 40 & $(28.5 \%)$ \\
\hline $46-55$ years & 40 & $(28.5 \%)$ \\
\hline $56-65$ years & 4 & $(3 \%)$ \\
\hline $\begin{array}{l}\text { Average working history as nurse; } \\
\text { (Min-Max; SD) }\end{array}$ & Mean & $(0.5-36.0 ; 8.9)$ \\
\hline $\begin{array}{l}\text { Average hours worked per week; } \\
\text { (Min-Max; SD) }\end{array}$ & Mean & $(9.0-38.0 ; 7.1)$ \\
\hline Level 1 & 4 & $(3 \%)$ \\
\hline Level 2 & 20 & $(14 \%)$ \\
\hline Level 3 & 98 & $(70 \%)$ \\
\hline Level 4 & 14 & $(10 \%)$ \\
\hline Level 5 & 4 & $(3 \%)$ \\
\hline Taking care of child & 94 & $(67 \%)$ \\
\hline \multicolumn{3}{|l|}{ Kind of irregular working hours } \\
\hline$\circ \quad$ Nightshift & 6 & $(4 \%)$ \\
\hline Evening shift & 6 & $(4 \%)$ \\
\hline Morning / Evening shift & 50 & $(36 \%)$ \\
\hline Morning / Night shift & 1 & $(1 \%)$ \\
\hline Evening / Night shift & 3 & $(2 \%)$ \\
\hline Morning / Evening/ Night shift & 74 & $(53 \%)$ \\
\hline
\end{tabular}

The demographics of the nurses can be seen in Table 1. The majority of participants were females $(133,95 \%)$, worked in a nursing home $(120,86 \%)$ and were aged 35 years or older $(84,60 \%)$. The majority $(74,53 \%)$ worked all different shifts (a combination of morning, late and night shifts), while others worked a combination of early and late shifts $(50,36 \%)$. The mode educational level was level 3, which is comparable with the level of a care worker (50).
The means, standard deviations and reliabilities for the variables studied are presented in Table 2. Some values from Table 2 are worth noting. For all scales, Cronbach's alpha reliabilities were greater than 0.70 , which is considered acceptable (51). The respondents scored just above the mean on the new SIW scale $(M=3.64 ; 1-5)$. They were also of approximately the same age and level of education as the average Dutch level of nurses working in nursing homes and care homes (52).

Table 2: Means, standard deviations and Cronbach's alphas

\begin{tabular}{|c|c|c|c|c|c|c|}
\hline & Variable & $\begin{array}{l}\text { Theoretical } \\
\text { Range }\end{array}$ & Direction & Mean & $S D$ & Cronbach's a \\
\hline \multirow{3}{*}{$\begin{array}{l}\text { Work } \\
\text { characteristics }\end{array}$} & Job demands & $1-5$ & $\begin{array}{l}\text { Higher values indicate } \\
\text { more job demands }\end{array}$ & 2.86 & .68 & 0.90 \\
\hline & Autonomy & $1-5$ & $\begin{array}{l}\text { Higher values indicate } \\
\text { more autonomy }\end{array}$ & 2.88 & .55 & 0.82 \\
\hline & Social support & $1-4$ & $\begin{array}{l}\text { Higher values indicate } \\
\text { more social support }\end{array}$ & 3.30 & .34 & 0.81 \\
\hline \multirow{3}{*}{$\begin{array}{l}\text { Home } \\
\text { characteristics }\end{array}$} & Home demands & $1-5$ & $\begin{array}{l}\text { Higher values indicate } \\
\text { more home demands }\end{array}$ & 3.37 & .67 & 0.82 \\
\hline & Autonomy at home & $1-4$ & $\begin{array}{l}\text { Higher values indicate } \\
\text { more autonomy at } \\
\text { home }\end{array}$ & 1.70 & .94 & na \\
\hline & $\begin{array}{l}\text { Social support at } \\
\text { home }\end{array}$ & $1-4$ & $\begin{array}{l}\text { Higher values indicate } \\
\text { more social support } \\
\text { at home }\end{array}$ & 1.94 & .69 & 0.71 \\
\hline SIW & $\begin{array}{l}\text { Satisfaction with } \\
\text { irregular } \\
\text { working hours }\end{array}$ & $1-5$ & $\begin{array}{l}\text { Higher values indicate } \\
\text { more satisfaction with } \\
\text { irregular } \\
\text { working hours }\end{array}$ & 3.64 & .49 & 0.89 \\
\hline \multirow{3}{*}{ Health } & Health complaints & $0-13$ & $\begin{array}{l}\text { Higher values } \\
\text { indicate more health } \\
\text { complaints }\end{array}$ & 2.99 & 2.62 & 0.76 \\
\hline & Emotional exhaustion & $0-6$ & $\begin{array}{l}\text { Higher values indicate } \\
\text { more emotional } \\
\text { exhaustion }\end{array}$ & 1.61 & .97 & 0.86 \\
\hline & General fatigue & $1-5$ & $\begin{array}{l}\text { Higher values indicate } \\
\text { more general fatigue }\end{array}$ & 2.43 & 1.08 & 0.87 \\
\hline
\end{tabular}

\section{Regression analyses}

To examine the relationships between work and home characteristics on the one hand and SIW and health on the other, multiple regression analyses were performed. The results are presented in Table 3.The regression analyses demonstrated that, for SIW, social support from colleagues and supervisors, job demands and autonomy at work accounted for $24 \%$ of the variance. For health complaints, job demands accounted for $12 \%$ of the variance. For emotional exhaustion, job demands, 
educational level and autonomy at home explained $20 \%$ of the variance. Lastly, for general fatigue, job demands, age and demands at home explained $25 \%$ of the variance. In all of the above, the variables explaining the variance were presented in order of importance.

As stated earlier, certain conditions have to be met prior to investigating the potential mediating role of SIW in the relationship between work and home characteristics on the one hand and health variables on the other hand. The results reported above show that only the variable job demands fulfilled the first two conditions, namely being related to both the health variables and SIW (see Table 3). To test the third and fourth condition, regression analyses were conducted for all health variables with SIW and the work and home characteristics as the independent variable, and correcting for potential confounders.

Table 3: Multiple regressions of health and Satisfaction with Irregular Working Hours (SIW) on work and home characteristics, controlling for background variables.

\begin{tabular}{|c|c|c|c|c|c|c|c|c|c|}
\hline \multirow{2}{*}{\multicolumn{2}{|c|}{$\begin{array}{c}\text { Variables } \\
\mathrm{n}=140\end{array}$}} & \multirow[t]{2}{*}{ SIW } & & \multicolumn{2}{|l|}{$\begin{array}{l}\text { Health } \\
\text { complaints }\end{array}$} & \multirow[t]{2}{*}{$\begin{array}{l}\text { Emotional } \\
\text { exhaustion }\end{array}$} & \multicolumn{3}{|c|}{$\begin{array}{l}\text { General } \\
\text { fatigue }\end{array}$} \\
\hline & & & B & & B & & B & & B \\
\hline \multirow{7}{*}{$\begin{array}{l}\text { Background } \\
\text { variables }\end{array}$} & $\Delta R^{2}$ Step 1 & $12 \% p=.005$ & & $4 \% \quad p=.311$ & & $14 \% p=.001$ & & $15 \% p=.000$ & \\
\hline & Age & & .05 & & -.11 & & -.12 & & $-.38^{* * *}$ \\
\hline & $\begin{array}{l}\text { Educational } \\
\text { level }\end{array}$ & & -.02 & & -.02 & & $.20^{*}$ & & .00 \\
\hline & Work location & & .14 & & .15 & & -.07 & & .07 \\
\hline & $\begin{array}{l}\text { Working } \\
\text { history }\end{array}$ & & -.06 & & .04 & & -.05 & & .10 \\
\hline & $\begin{array}{l}\text { Taking care of } \\
\text { children }\end{array}$ & & .07 & & .06 & & -.10 & & -.04 \\
\hline & $\Delta R^{2}$ Step 2 & $18 \% p=.000$ & & $15 \% p=.001$ & & $12 \% p=.003$ & & $15 \% p=.000$ & \\
\hline \multirow{3}{*}{$\begin{array}{l}\text { Work } \\
\text { characteristics }\end{array}$} & Job demands & & $-.19^{*}$ & & $.39^{* * *}$ & & $.25^{* *}$ & & $.38^{* * *}$ \\
\hline & Autonomy & & $.16^{*}$ & & .00 & & -.15 & & .04 \\
\hline & Social support & & $.27^{* *}$ & & -.10 & & -.09 & & -.08 \\
\hline \multirow[t]{5}{*}{$\begin{array}{l}\text { Home } \\
\text { characteristics }\end{array}$} & $\begin{array}{l}\text { Home } \\
\text { demands }\end{array}$ & & -.06 & & .09 & & .11 & & $.19^{*}$ \\
\hline & $\begin{array}{l}\text { Autonomy at } \\
\text { home }\end{array}$ & & .09 & & -.08 & & $-.17^{*}$ & & -.04 \\
\hline & $\begin{array}{l}\text { Social support } \\
\text { at home }\end{array}$ & & .08 & & -.02 & & .01 & & -.09 \\
\hline & $R^{2}$ total & $30 \% p=.000$ & & $19 \% p=.003$ & & $26 \% p=.000$ & & $31 \% p=.000$ & \\
\hline & $\begin{array}{l}\text { Adjusted } R^{2} \\
\text { total }\end{array}$ & $24 \%$ & & $12 \%$ & & $20 \%$ & & $25 \%$ & \\
\hline
\end{tabular}

${ }^{*} \mathrm{p}<.05,{ }^{* *} \mathrm{p}<.01,{ }^{* * *} \mathrm{p}<.00$

Work location: nursery home $=0$, care home $=1$

Care of children: $n o=0$, yes $=1$

$=$ is the standardised regression coefficient.

The $B$ values shown are the coefficients from the final stage of the regression analysis, the second step.

$\Delta R^{2}$ is the change in variance (in \%) associated with adding each block sequentially into the regression equation.

$\mathrm{R}^{2}$ total refers to the variance (in \%) explained by all selected variables.
Table 4: Multiple regressions of health on Satisfaction with Irregular Working Hours (SIW), controlling for background variables.

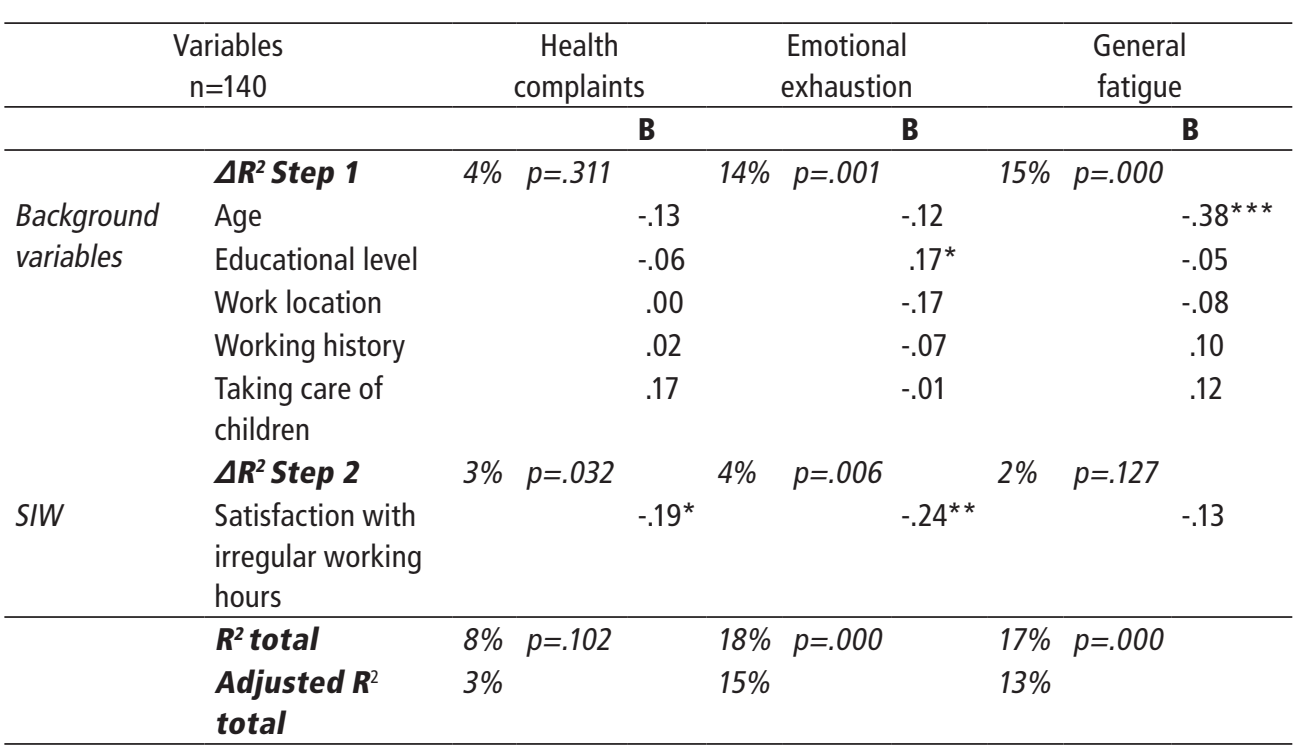

${ }^{*} \mathrm{p}<.05,{ }^{* *} \mathrm{p}<.01,{ }^{* * *} \mathrm{p}<.001$

Work location: nursery home $=0$, care home $=1$

Care of children: no $=0$, yes $=1$

$B=$ is the standardised regression coefficient.

The $B$ values shown are the coefficients from the final stage of the regression analysis, the second step. $\Delta R^{2}$ is the change in variance (in \%) associated with adding each block sequentially into the regression equation.

$R^{2}$ total refers to the variance (in \%) explained by all selected variables.

As shown in Table 4, SIW was associated with health complaints and emotional exhaustion, but not with general fatigue when controlling for background characteristics. However, after controlling for work characteristics and home characteristics in addition to background characteristics, we found no association between SIW and health complaints, emotional exhaustion or general fatigue (Table 5), Furthermore, the associations between job demands and the health variables did not (partially or completely) disappear. 
Table 5: Multiple regressions of health on Satisfaction with Irregular Working Hours (SIW), controlling for background variables, home and work characteristics.

\begin{tabular}{|c|c|c|c|c|c|c|c|c|c|c|}
\hline \multicolumn{2}{|c|}{$\begin{array}{c}\text { Variables } \\
n=140\end{array}$} & \multicolumn{3}{|c|}{$\begin{array}{c}\text { Health } \\
\text { complaints }\end{array}$} & \multicolumn{3}{|c|}{$\begin{array}{l}\text { Emotional } \\
\text { exhaustion }\end{array}$} & \multicolumn{3}{|c|}{$\begin{array}{l}\text { General } \\
\text { fatigue }\end{array}$} \\
\hline & & & & B & & & B & & & B \\
\hline & $\Delta R^{2}$ Step 1 & $4 \%$ & $p=.311$ & & $14 \%$ & $p=.001$ & & $15 \%$ & $p=.000$ & \\
\hline \multirow{6}{*}{$\begin{array}{l}\text { Background } \\
\text { variables }\end{array}$} & Age & & & -10 & & & -.12 & & & $-.38^{* * *}$ \\
\hline & Educational level & & & .02 & & & $.20^{*}$ & & & .00 \\
\hline & Work location & & & .15 & & & -.05 & & & .07 \\
\hline & Working history & & & .03 & & & -.06 & & & .10 \\
\hline & $\begin{array}{l}\text { Taking care of } \\
\text { children }\end{array}$ & & & .06 & & & -.09 & & & -.04 \\
\hline & $\Delta R^{2}$ Step 2 & $3 \%$ & $p=.032$ & & $5 \%$ & $p=.006$ & & $2 \%$ & $p=.127$ & \\
\hline \multirow[t]{2}{*}{ SIW } & $\begin{array}{l}\text { Satisfaction with } \\
\text { irregular working } \\
\text { hours }\end{array}$ & & & -.06 & & & -.11 & & & .00 \\
\hline & $\Delta R^{2}$ Step 3 & $12 \%$ & $p=.007$ & & $8 \%$ & $p=.029$ & & $14 \%$ & $p=.001$ & \\
\hline Work & Job demands & & & $.38^{* * *}$ & & & $.23^{*}$ & & & $.38^{* * *}$ \\
\hline \multirow{2}{*}{ characteristics } & Autonomy & & & .01 & & & -.13 & & & .04 \\
\hline & Social support & & & -.09 & & & -.06 & & & -.08 \\
\hline Home & Home demands & & & .08 & & & .10 & & & $.19^{*}$ \\
\hline \multirow[t]{3}{*}{ characteristics } & $\begin{array}{l}\text { Autonomy at } \\
\text { home }\end{array}$ & & & -.07 & & & -.16 & & & -.04 \\
\hline & $\begin{array}{l}\text { Social support at } \\
\text { home }\end{array}$ & & & -.02 & & & .02 & & & -.09 \\
\hline & $\begin{array}{l}R^{2} \text { total } \\
\text { Adjusted } R^{2} \\
\text { total }\end{array}$ & $\begin{array}{l}19 \% \\
12 \%\end{array}$ & $p=.005$ & & $\begin{array}{l}27 \% \\
20 \%\end{array}$ & $p=.000$ & & $\begin{array}{l}31 \% \\
24 \%\end{array}$ & $p=.000$ & \\
\hline
\end{tabular}

${ }^{*} \mathrm{p}<.05,{ }^{* *} \mathrm{p}<.01,{ }^{* * *} \mathrm{p}<.001$

Work location: nursery home $=0$, care home $=$

Care of children: no $=0$, yes $=1$

$B=$ is the standardised regression coefficient.

The $B$ values shown are the coefficients from the final stage of the regression analysis, the third step.

$\Delta \mathrm{R}^{2}$ is the change in variance (in \%) associated with adding each block sequentially into the regression equation

$\mathrm{R}^{2}$ total refers to the variance (in \%) explained by all selected variables in the blocks

In summary, referring to Figure 1, health variables were explained by work as well as home characteristics (arrow 2), while SIW was only explained by work characteristics (arrow 1). SIW was found to be associated with health variables (arrow 3). Lastly, we did not find evidence that SIW mediates the relationships between work characteristics on the one hand and health on the other hand (arrow 4).

\section{DISCUSSION}

This research brought additional answers to questions about how the employees' working and home situations affect their satisfaction with irregular working hours (SIW) that are a form of shiftwork and their health.

\section{Study limitations}

The findings of this study should be interpreted in the context of a few limitations. First, because the study was cross-sectional, we cannot conclude that causal relationships exist between the variables. As a result, the role of SIW remains somewhat unclear.

Second, although our SIW scale clearly refers to social and practical consequences of shiftwork and has high reliability, in future work we may consider including an item about satisfaction with the extra payment for working shifts. Although, earlier research (53) showed that the focus of nurses was directed to the social and health-related aspects of their working hours, recent work has shown a positive relationship between rewards and job satisfaction (54).

Third, the relatively small sample size $(n=140)$, and the fact that all respondents had the same employer, reduced the external validity of our study. Nonetheless, our sample was comparable in age and level of education to the general nursing population working in nursing and care homes in the Netherlands.

Finally, because the questionnaires used to measure work and home characteristics and outcome variables were self-reported, common method variance may have occurred: a common problem which plagues most questionnaire-based research $(55,56)$. Future researchers can avoid this potential source of confounding by collecting data from additional sources.

\section{Discussion of results}

Our assumptions based on the JDCS model (33) were confirmed for SIW but home characteristics were not associated with SIW. This contradicts the assumption of some models that claim that attitudes towards working hours are influenced by both the work and the home situation (57) However, it is possible that nurses who, because of their work schedules, are less socially integrated, focus more on their work situation than on their home situation when experiencing stress. This seems to be especially applicable to social support at work (58), which in our study demonstrated the strongest association with SIW.

Our results also showed that job demands contribute statistically significantly to nurses' health problems (59). Those who experienced many demands at home also reported more general fatigue. De Rijk et al. (60) also found that having many demands (at home as well as at work) was a strong predictor for general fatigue. In addition, our nurses who reported more autonomy at home experienced less emotional exhaustion. Perhaps the availability of more resources in one domain (in 
this case, the home) acts as a resource for adapting to demands in a different domain (in this case, at work). This suggests that home and work domains should not be viewed as mutually- exclusive domains. This is in line with the conservation of resources theory (61).

Social support was found to be related to a specific attitude towards the job, namely SIW. Similarly, in the work of Bradley and Cartwright (62) and Gelsema et al. (63), social support predicted job satisfaction only, and not health complaints.

Nurses who were more satisfied with their irregular working hours experienced fewer health complaints and less emotional exhaustion. Fatigue is apparently not related to the way employees feel about their schedule and the psychological meaning of their work schedules. Shiftwork is related to fatigue (64). Our findings mean that the key in preventing emotional exhaustion and psychosomatic health complaints is keeping nurses satisfied with their irregular working hours.

Older nurses experienced less general fatigue than younger nurses, but age differences were not found for the other health variables. It is possible that this association is due to the healthy worker effect (65). This effect is a form of self-selection; employees who were unable to do shiftwork due to various health problems already stopped working shifts. Since fatigue has been found to be an important factor in determining whether to stop working shifts (22), the healthy worker effect is a feasible explanation. However, it is also possible that younger nurses experience more stress and fatigue due to higher family responsibilities compared to older nurses, although the latter may care for older relatives.

SIW did not mediate the relationships between the work and home characteristics on the one hand and health on the other. It is possible that dissatisfaction with work schedules generates more negative perceptions of the work situation, which in turn yield more health problems. If so, work characteristics (e.g. job demands) would be the mediating factor. It is also possible that SIW interacts with work and home characteristics. For example, when nurses are dissatisfied with their work schedules, they may be less able to cope with job demands and therefore experience more stress.

\section{CONCLUSION}

Shiftwork will always been required in nursing and care homes worldwide, and therefore it is necessary to take some measures to alleviate the potential stress resulting from this.

Job demands are by far the most important factor in relation to decreased health outcomes. Employers should consider the distribution of job demands, with a view to ensuring the best match between the demands and employee. In addition, supervisors should consider their employees' situation at home (both demands and autonomy) when supporting them. Because shiftwork in nursing is inevitable, nurses' satisfaction with their working hours should be promoted, for example giving them more control over their schedules. They should also be taught how to take advantage of working irregular hours, which are a form of shiftwork that may prevent them from emotional exhaustion and health complaints. Decreasing the outflow of young healthcare personnel in particular is imperative and consistent with other research; our findings regarding fatigue levels suggested that particularly younger nurses need attention. Regular health assessments could help to detect health problems at an early stage especially for employees who are dissatisfied with their irregular working hours, a form of shiftwork.

With regard to further research, the SIW scale should be further validated. Reliability scores for the scales used were adequate, but the scale measuring autonomy at home was a one-item scale. We recommend expanding this scale to include other items, such as the degree to which one can participate in the allocation of tasks at home. 


\section{REFERENCES}

1. RVZ. Arbeidsmarkt en zorgvraag. [The labour market and the demand for care]. . Zoetermeer2006

2. Goodin HJ. The nursing shortage in the United States of America: an integrative review of the literature. Journal of Advanced Nursing. 2003;43(4):335-43.

3. Spitzer A, Camus D, Desaulles C, Kuhne N. The changing context of Western European healthcare systems: Convergence versus divergence in nursing problematics. Social Science \& Medicine. 2006 2006/10/01/;63(7):1796-810.

4. Kingma M. Nurses on the Move: A Global Overview. Health Services Research. 2007;42(3p2):1281-98.

5. LEVV. Factsheet: Het ziekteverzuim inclusief en exclusief zwangerschapverlof per branche (2001-2005) [Factsheets: sickness absence in the health care sector]. . Utrecht: LEVV2006.

6. Costa G. The impact of shift and night work on health. Applied Ergonomics. 1996 Feb;27(1):9-16.

7. Harrington JM. Health effects of shift work and extended hours of work. Occupational and Environmental Medicine. 2001 January 1, 2001;58(1):68-72.

8. Knutsson A. Health disorders of shift workers. Occup Med (Lond). 2003 March 1, 2003;53(2):103-8.

9. Jamal M. Burnout, stress and health of employees on non-standard work schedules: a study of Canadian workers. Stress and Health. 2004;20(3):113-9.

10. Kilpatrick K, Lavoie-Tremblay M. Shiftwork: What Health Care Managers Need to Know. The Health Care Manager. 2006;25(2):160-6

11. Kivimäki M, Kuisma P, Virtanen M, Elovainio M. Does shift work lead to poorer health habits? A comparison between women who had always done shift work with those who had never done shift work. Work \& Stress. 2001 2001/01/01;15(1):3-13.

12. Besseling JJM, van Genabeek J, Wevers CWJ, Zwinkels WS. Epidemiologie van verzuim, arbeidsongeschiktheid en reïntegratie. Boekblok Arbeid en Belastbaarheid. Houten: Bohn Stafleu van Loghum; 2002. p. 14-38.

13. Sagie A, Krausz M. What aspects of the job have most effect on nurses? Human Resource Management Journal. 2003;13(1):46-62.

14. De Veer A, Poortvliet E, Vogel B, Francke A. De aantrekkelijkheid van het beroep 2007. Een peiling onder het Panel Verpleegkundigen en Verzorgenden. Utrecht: NIVEL/V\&VV/LEVV. 2007.

15. Grunveld JE. Arbeidstevredenheid, verloop en uitval in de gezondheidszorg [job satisfaction,turnover and job leave in health care]. . Utrecht: Prismant2002.

16. Adams J, Folkard S, Young M. Coping strategies used by nurses on night duty. Ergonomics. 1986 1986/02/01;29(2):185-96.

17. Ruggiero JS, Pezzino JM. Nurses' perceptions of the advantages and disadvantages of their shift and work schedules. The Journal of nursing administration. 2006 0ct;36(10):450-3.

18. Knutsson A. Methodological Aspects of Shift-Work Research. Chronobiology International: The Journal of Biological and Medical Rhythm Research. 2004;21(6):1037 - 47.

19. Rosa R, Colligan M. Plain language about shiftwork. Cincinnati, OH: Department of Health and Human Services, Public Health Service, Centers for Disease Control and Prevention, National Institute for Occupational Safety and Health, Division of Biomedical and Behavioral Science, (NIOSH); 1997.

20. Definitie: Onregelmatige werktijden [Definition: Irregular working hours] [database on the Internet]. Statistics Netherlands. 2007 [cited 01-11-2008]. Available from: www.cbs.nl.
21. Coffey LC, Skipper JK, Jung FD. Nurses and shift work: effects on job performance and job-related stress. Journal of Advanced Nursing. 1988;13(2):245-54.

22. Jansen N, Van Amelsvoort L, Kristensen T, Van den Brandt P, Kant I. Work schedules and fatigue: prospective cohort study. Occupational and Environmental Medicine. 2003 June 2003;60(suppl 1):47-53.

23. Houtman I, de Jonge J. De epidemiologie van werkgerelateerde psychische aandoeningen en klachten [The epidemiology of work related psychological disorders and complaints]. In: Schaufeli W, Bakker A editors. De psychologie van arbeid en gezondheid. Houten: Bohn Stafleu van Loghum; 2003. p. 265-80.

24. Van der Windt W, Calsbeek H, Talma H, Hingstman L. Feiten over verpleegkundige en verzorgende beroepen in Nederland 2003 (Facts about nursing professions in the Netherlands 2003). Utrecht: The Netherlands Centre for Excellence in Nursing (LEVV). 2003.

25. Essen vG, Paardekooper PJ, Talma HF, Windt vdW. Rapport Arbeid in Zorg en Welzijn 2006 [Report of the work in health care, 2006]. Utrecht: Prismant2006.

26. Sundin L, Hochwälder J, Bildt C, Lisspers J. The relationship between different work-related sources of social support and burnout among registered and assistant nurses in Sweden: A questionnaire survey. International Journal of Nursing Studies. 2007;44(5):758-69.

27. Groenendijk H. Werken en zorgen: de moeite waard. Een onderzoek naar het welbevinden naar buitenshuis werkende moeders [Working and caring worth the trouble. A study on the well-being of mothers who work outside the home]. Utrecht: uitgeverij Jan van Arkel1998.

28. Peeters MCW, Heiligers P, editors. Werk-thuisinterferentie [Work home interference]. Houten/Mechelen: BSVL; 2003.

29. Demir A, Ulusoy M, Ulusoy MF. Investigation of factors influencing burnout levels in the professional and private lives of nurses. International Journal of Nursing Studies. 2003;40(8):807-27.

30. Staland-Nyman C, Alexanderson K, Hensing G. Associations between strain in domestic work and self-rated health: A study of employed women in Sweden. Scand J Public Health. 2008 January 1, 2008:36(1):21-7.

31. Pisarski A, Bohle P, Callan VJ. Effects of coping strategies, social support and work-nonwork conflict on shift worker's health. Scand J Work Environ Health. 1998;24:141-5.

32. Winwood PC, Winefield AH, Lushington K. Work-related fatigue and recovery: the contribution of age, domestic responsibilities and shiftwork. Journal of Advanced Nursing. 2006;56(4):438-49.

33. Karasek RA, Theorell T. Healthy Work: Stress, Productivity and the Reconstruction of Working Life. New York: Basic Books; 1990

34. De Rijk AE, Le Blanc PM, Schaufeli WB, De Jonge J. Active coping and need for control as moderators of the job demand-control model: Effects on burnout. Journal of Occupational \& Organizational Psychology. [Article]. 1998;71(1):1-18

35. Wagena E, Geurts S. SWING, ontwikkeling en validering van de 'survey werk-thuis interferentie-Nijmegen Gedrag en gezondheid. 2000;28:138-58.

36. Krausz M, Sagie A, Bidermann Y. Actual and Preferred Work Schedules and Scheduling Control as Determinants of Job-Related Attitudes. Journal of Vocational Behavior. 2000;56(1):1-11

37. Zaccaro SJ, Stone EF. Incremental validity of an empirically based measure of job characteristics. Journal of Applied Psychology. 1988;73(2):245. 
38. Yousef DA. Job Satisfaction as a Mediator of the Relationship Between Job Stressors and Affective, Continuance, and Normative Commitment: A Path Analytical Approach. International Journal of Stres Management. [journal article]. 2002 April 01;9(2):99-112.

39. Crede M, Chernyshenko OS, Stark S, Dalal RS, Bashshur M. Job satisfaction as mediator: An assessment of job satisfaction's position within the nomological network. Journal of Occupational and Organizational Psychology. 2007;80(3):515-38.

40. Evers A, editor. Individuele assessment [individual assessment]. Houten/Mechelen: BSVL; 2003.

41. De Jonge J. Job autonomy, well-being, and health. Maastricht: Maastricht University; 1995.

42. Bergers GPA, Marcelissen FHG, De Wolff CJ. Handleiding Vragenlijst Organisatiestress-Doetinchem (VOS-D). Nijmegen: Katholieke Universiteit Nijmegen1986.

43. Nachreiner F. Individual and social determinants of shiftwork tolerance. Scand J Work Environ Health. 1998;24:35-42.

44. Polit DF, Hungler BP. Nursing research principles and methods. Phyladelphia: Lippincott Williams and Wilkins; 1999.

45. Dirken JM. Arbeid en stress [work and stress]. Groningen: Wolters Noordhof; 1969.

46. Smets EMA, Garssen B, Bonke B, De Haes JCJM. The multidimensional Fatigue Inventory (MFI) psychometric qualities of an instrument to assess fatigue. Journal of Psychosomatic Research. 1995;39(3):315-25.

47. Schaufeli WB, Van Dierendonck D. Burnout, een begrip gemeten: De Nederlandse versie van de Maslach Burnout Inventory (MBI-NL) [Burnout, the measurement of a construct. The Dutch version of the Maslach Burnout Inventory (MBI-NL)]. Tijdschrift voor Psychologie en Gezondheid. 1994;22(4):153-72.

48. Baron RM, Kenny DA. The moderator-mediator variable distinction in social psychological research: conceptual, strategic, and statistical considerations. J Pers Soc Psychol. 1986 Dec;51(6):1173-82.

49. Voeten MJM, Van den Bercken JHL. Lineaire regressieanalyse, Introductie op meervoudige regressie en verwante procedures: Handboek. Groningen: Stenfert Kroese; 2003.

50. Westerhuis A. European Structures of Qualification Levels: A Synthesis Based on Reports on Recent Developments in Germany, Spain, France, the Netherlands and the United Kingdom (England and Wales). Volume 1. CEDEFOP Reference Series: ERIC; 2001.

51. Cortina JM. What is coefficient alpha? An examination of theory and applications. Journal of Applied Psychology. 1993;78(1):98-104.

52. Meulen-Arts S, Francke AL. Hoe groot is het aanbod en neemt het toe of af? [How big is the supply and is it decreasing or increasing?] Bilthoven: Nationaal Kompas Volksgezondheid, RIVM; 2003 [cited 2003 12 - 7]; Available from: http://www.nationaalkompas.nl.

53. Bussing A. Social tolerance of working time scheduling in nursing. Work Stress. [Proceedings Paper] 1996 Jul-Sep;10(3):238-50.

54. Castle NG, Engberg J, Anderson R, Men A. Job Satisfaction of Nurse Aides in Nursing Homes: Intent to Leave and Turnover. The Gerontologist. 2007 April 2007;47(2):193-204.

55. Podsakoff PM, MacKenzie SB, Lee JY, Podsakoff NP. Common method biases in behavioral research: a critical review of the literature and recommended remedies. J Appl Psychol. [Review]. 2003 Oct;88(5):879-903.

56. Spector PE. Method variance in organizational research: truth or urban legend? Organizational Research Methods. 2006;9(2):221-32.

57. Taylor E, Briner RB, Folkard S. Models of shiftwork and health: An examination of the influence of stress on shiftwork theory. Human Factors. 1997;39(1):67-82.
58. Schmieder RA, Smith CS. Moderating effects of social support in shiftworking and non-shiftworking nurses. Work \& Stress. 1996 1996/04/01;10(2):128-40.

59. McVicar A. Workplace stress in nursing: a literature review. Journal of Advanced Nursing. 2003 Dec;44(6):633-42.

60. De Rijk AE, Schreurs KMG, Bensing JM. What is behind "i'm so tired"? fatigue experiences and their relations to the quality and quantity of external stimulation. Journal of Psychosomatic Research. 1999 1999/12/01/;47(6):509-23.

61. Hobfoll SE. Conservation of Resources; A New Attempt at Conceptualizing Stress. American Psychologist. 1989;44(3):513-24

62. Bradley JR, Cartwright S. Social Support, Job Stress, Health, and Job Satisfaction Among Nurses in the United Kingdom. International Journal of Stress Management. [journal article]. 2002 July 01:9(3):163-82.

63. Gelsema TI, Van Der Doef M, Maes S, Janssen M, Akerboom S, Verhoeven C. A longitudinal study of job stress in the nursing profession: causes and consequences. Journal of Nursing Management. 2006;14(4):289-99.

64. Jansen N, Kant I, van Amelsvoort L, Nijhuis F, van den Brandt P. Need for recovery from work: evaluating short-term effects of working hours, patterns and schedules. Ergonomics. 2003;46(7):664-80.

65. van Amelsvoort L, Jansen N, Swaen G, van den Brandt P, Kant I. Direction of shift rotation among threeshift workers in relation to psychological health and work-family conflict. Scand J Work Environ Health. 2004;30(2):149-56 


\section{APPENDIX 1: THE SATISFACTION WITH IRREGULAR WORKING HOURS SCALE}

\section{Item number}

In general, how satisfied are you with working irregular hours?

How satisfied are you with the amount of time you are able to spend with your family and friends outside of work?

3 How satisfied are you with the amount of time you are able to spend on your leisure activities

and hobbies (sports, club, going out with others)?

How satisfied are you with the quality of your sleep given your irregular working hours?

How satisfied are you with the fact that you often have to work on the weekends?

How satisfied are you with the fact that you can go shopping on week days (clothing, presents

and others) because of your irregular working hours?

7 How satisfied are you with the fact that you can take care of certain things (car reparation,

cleaning the house, and seeing others) because you work irregular hours?

How satisfied are you with the fact that you sometimes have to work during holidays due to your

irregular working hours?

9 How satisfied are you with the quality of your eating habits given your irregular working hours?

10 How satisfied are you with the combination of irregular work - leisure time?

11 How satisfied are you with the variation in work given your irregular working hours?

12 How satisfied are you with the quality of your contact with family, friends and spouse given your irregular working hours?

13 How satisfied are you in general with the scheduling of your irregular working hours? 


\section{ABSTRACT}

Background: Work Schedules Contribute Substantially To The Health And Well-Being Of Nurses. Too Broad Typologies Are Used In Research That Do Not Meet The Current Variety In Work Schedules.

Objective: To Develop A New Typology For Nurses' Work Schedules Based On Five Requirements And To Validate The Typology.

Methods: This Study Is Based On A Questionnaire Returned By 498 Nurses (Response 51\%) Including Questions Regarding Nurses' Work Schedule, Socio-Demographic, And Family Characteristic And Their Appraisal Of The Work Schedule. Frequencies Of The Different Schedules Were Computed To Determine The Typology. To Validate The Typology, Differences Between The Types Were Tested With Anovas, Chi And Kruskal-Wallis Tests.

Results: Five Main Types Can Be Distinguished Based On Predetermined Requirements And Frequencies, Namely: (1) Fixed Early Shift, (2) Rotating Two Shift Pattern Without Night Shift, (3) Rotating Three Shift Pattern, (4) Fixed And Rotating Two Shift Pattern Including Night Shift, And (5) Fixed Normal Day Or Afternoon Shifts. Nurses In These Types Of Work Schedule Differed Significantly With Respect To Hours Worked, Days Off Between Shifts, Age, Education, Years In The Job, Commuting Time, Contribution To Household Income, Satisfaction With Work Schedule And Work Schedule Control. Especially Nurses With Type 3 Schedules Differed From Other Types.

Conclusions: A Typology Of Five Main Types Of Working Schedules Is Proposed. Content Validity Of The Typology Is Sufficient And The New Typology Seems Useful For Research On WorkRelated Aspects Of Nursing.

\section{INTRODUCTION}

Shiftwork is high on the list of factors that contribute to leaving health care and decreasing quality of care in the Netherlands and globally as well (1-4). In research, shiftwork is often broadly defined as working outside the normal daytime hours (5-7). Research on shiftwork is hampered by broad and indistinct operationalizations of work schedules $(6,8)$ which do not meet the current variety of work schedules. Merkus et al. (6) showed in their extensive systematic review that especially in health care, the influence of shiftwork on outcomes might be schedule and population (female) specific. Even high quality studies used in their review did not specify or differentiate between work schedule characteristics. It is difficult to interpret and compare research on work schedules because of the lack of detailed information (6). It thus seems important to develop a typology of work schedules that meets the above-mentioned problems.

Although 'nurse' indicates normally the qualification level of a registered nurse, the current research uses this term for nurses working in residential elder care in the Netherlands. This includes registered nurses, enrolled nurses, licensed vocational or practical nurses and nurse care helpers. In the Netherlands nurses working in residental elder care are comparable with respect of qualification level to Dutch nurses working in hospitals, home care, care for disabled people and mental health care but do have different psychosocial and physical demands (9). The proportion in Europe of registered nurses, enrolled nurses, licensed vocational or practical nurses is the highest in hospital care followed by residential elder (10). The proportion of registered nurses working in residential elder care varies between European countries with the Netherlands as a leading country (11).

Nurses are among the workers who work in different work schedules. Work schedules are changing $(2,12)$ and the work schedule a nurse works in usually changes during her career. Although irregular working hours are mandatory, the choice for the type of schedule is, to some extent, up to the nurses themselves and to their supervisors (13). Choice options are expected to increase $(3,12)$ due to nursing shortages and increasing numbers of freelance nurses. This leads to an increasing variety of types of work schedules $(2,3,14)$. The variety of work schedules is probably greater now than it has ever been (15).

There seems to be no scientific agreement on what the best work schedule typology is $(7,8$, 16). Therefore, the influence of specific work schedules can not be fully studied and research that focuses on, for example, the effects of shiftwork on well-being and employability will consequently be hampered.

\section{Background}

A meaningful typology for the large diversity in contemporary work schedules should reflect the degree to which a schedule disturbs the biological rhythm, sleep, family life and social life (17). Evidence seems to be indicating $(18,19)$ that it is important for research to distinguish between 
different types of fixed and rotational shifts, in order to detect differences between the types of schedules besides the usual distinction between fixed and rotational work schedules. Often the two shift and three shift are combined. Other research showed significant differences between these shift schedules with respect to stress, health and job related attitudes, in disadvantage of the three shift schedule (20-22). Moreover, reviews on shiftwork show that nurses working in fixed shifts show fewer problems with respect to health and social and domestic problems than nurses working in rotating shifts $(23,24)$.

Especially for a dominantly female working population which most of the time has to combine work with duties at home $(25,26)$, sleep quality seems of great importance $(27,28)$. Night and early shifts affect, among other things, quality of sleep. Also the number of hours of night sleep before the early morning shifts and hours of day sleep after night shifts seems to be disturbed which diminishes the possibility to recover (29-33). Nurses with fixed schedules without nightshifts might be better able to combine work and care at home than nurses with a combination of rotating shifts. Early and evening shifts seem to cause conflict with other social and family activities, e.g. school timetables of children. Commuting time to work can interrupt sleep before going to an early shift $(8,33-36)$.

When defining the new types, the following requirements thus have to be met:

1. a distinction has to be made between fixed shift pattern versus rotating shifts (19);

2. a distinction has to be made between nightshifts versus no nightshift $(18,37)$; and

3. a distinction has to be made between early shifts versus day shift because of the combination with commuting time, which could affect sleep $(25,30)$

Furthermore, for research purposes the typology has to be concise but also has to cover the variety of work schedules. Therefore, the following criteria have also to be considered:

4. it has to represent the most prevalent types of work schedules in separate types; and

5. it has to classify not more than five types of schedules, in order to use the new typology in statistical analyses.

In addition, work schedule characteristics and nurse characteristics should differ across the types of work schedule according to the new typology to show sufficient construct validity. It can be expected that the work schedule types differ regarding work schedule characteristics, such as working part-time, working overtime and having days off $(16,38-40)$. Further, the nurses working in the different types might differ regarding socio-demographic characteristics and family characteristics $(3,14,41)$, but also regarding their appraisal, in terms of satisfaction with work schedule (42) and work schedule control.

Differences between the work schedule types can also be expected in the way the nurses appraise their work schedule. Employees will be more satisfied when they work the type of work schedule that fit their needs $(43,44)$. Female nurses might prefer non-standard working hours as a conscious choice to arrange work around childcare and their partners' job $(45,46)$. Decisions and choices around scheduling are influenced by family considerations and most often not by their own health and well-being, especially for workers with more extensive family responsibilities (26). Other studies show that the appraisal of the work schedule adds to the explanation of outcomes. Authors argue that employees' appraisals of 'objective' conditions (47), such as the work schedule, need to be included to fully take work schedules into consideration $(48,49)$. Peters et al. (42) found satisfaction with the work schedule (measured with the SIW scale), for example, to be strongly linked to health characteristics. Van Rijswijk (50) found that female employees, who work the schedule that fitted with their other responsibilities, experienced less work-home interference, in addition to objective characteristics such as the number of work hours and flextime. Furthermore perceived control over work time has been a major concern in recent research and seems to be an independent predictor of health, job attitudes and work-life conflict for women in particular $(51,52)$

\section{Objectives}

The objectives of this study are to define a contemporary typology of work schedules in nursing and to study differences between these types in terms of work schedule characteristics, sociodemographic characteristics, family characteristics, and the nurses' appraisal of the work schedule. The research questions are therefore as follow:

1. What is a useful typology of nowadays work schedules among nursing populations for both research and management purposes?

2. What are the work schedule characteristics of the types and what are the differences?

3. a) What are the nurses' socio-demographic and family characteristics and what is the appraisal of the work schedule by nurses in the different types of work schedule and,

b) What are these differences between nurses in the different types of work schedule?

\section{METHODS}

\section{Design}

A cross-sectional study was performed to answer the research questions. With the questionnaire, information was gathered in October 2009 regarding work schedule descriptives and characteristics, socio-demographic and family characteristics and the appraisal of the work schedule. The questionnaire was sent to the home addresses of all nursing employees working shifts in three residential elder care facilities in the Netherlands. Nurses were asked to return the questionnaires within two weeks. Reminder letters were sent to all participants two and three weeks after the initial distribution of the questionnaires. 


\section{Sample}

The study involved nurses working shifts in three residential elder care facilities in the Netherlands. The educational level of these nurses can be distinguished by five levels: level one, two and three refer to care helper providing basic care. Level four nurse implies secondary vocational education and is comparable with an enrolled nurse, licensed vocational or practical nurse, and level five implies higher vocational education with a bachelor degree and is comparable with a registered nurse (RN). The three homes for elder care that participated accommodate clients with psychogeriatric disorders and physical frailties. The organizations were included because the nurses' work schedules were representative because they seem to reflect the diversity of work schedules of nurses working in both acute or short-term aged care and long-term aged care settings in the Netherlands.

\section{Inclusion criteria}

Nurses were only included if they reported their type of work schedule and worked with - mostly - elderly clients with psycho-geriatric disorders and physical frailties. Of all nurses invited in this study ( $N=1009$ ), 974 met the inclusion criteria. Of these 974 nurses, 498 returned the questionnaire (response rate of $51 \%$ ). Exclusion criteria were being on sick leave for over twelve months and being younger than 18 years or older than 65 years of age.

\section{Measures}

The questionnaire assessed work schedule descriptives and characteristics, socio-demographic and family characteristics and the appraisal of the work schedule.

\section{Work schedule descriptives}

To collect data on the descriptives of the work schedules needed for developing the new typology, respondents were asked when their working days began and ended and which shifts they worked (morning, afternoon and night shifts). They were also asked whether they worked other shifts besides the standard morning, late and night shifts. Early shifts (start of work day between 6.00 a.m. and 7.30 a.m. and ending before 3.30 p.m.), 'normal' day shifts (start of work day between $7.00-8.00$ and ending between $4.00-5.00$ p.m.), late shifts (start of work day between 3.00 -5.00 p.m. and ending between $8.00-11.00$ p.m.) and night shifts (start of work day between 11.00 p.m. and ending around 7.00 a.m.). By asking when their shifts started and ended instead of using only predefined shift categories, we tried to prevent for misclassification of type of shift.

Work schedule characteristics

To test differences between work schedule types, the following work schedule characteristics were measured.
Average number of hours each week and average number of overtime hours each week were included in the questionnaire. Days off between two series of shifts was used to measure the ability to recover or take rest using a single item concerning the number of days off between two series of shifts. Prior knowledge of work schedule was operationalized by asking participants how many weeks in advance they were informed of their work schedules on a ordinal scale ranging from 1 'one week' to 5 'more than four weeks'. This was dichotomized into 0 'knowledge of schedule at least 2 weeks in advance' or 1 'less than two weeks in advance', because two weeks is mandatory according to the collective labour agreement.

Socio-demographics and family characteristics

Data regarding socio-demographic and family factors include sex, age, educational level, job status, marital status, partner's job status, partner's shiftwork, partner's average number of working hours per week, number of children $<12$ years, number of days children spent in day care per week, number of hours spent on care for family members per week, commuting time per workday and contribution to the total household income.

Appraisal of the work schedules

Satisfaction with work schedules was measured using the Satisfaction with Irregular Working times (SIW) scale (42). SIW refers to the extent to which nurses are satisfied with their irregular work schedules, particularly in the context of their leisure time, family situation, social circumstances, sleep and work-leisure time balance. The scale consists of fourteen items that are scored on a 5 -point response scale ranging from 1 'entirely dissatisfied' to 5 'entirely satisfied'.

Work schedule control was measured by 10 items. This scale measures the perceptions of having a choice in and influence on the scheduling of work regarding starting and ending times, days off, the taking of breaks during the workday, swapping shifts and taking unpaid leave. It consists of six items scored with either 1 'yes' or 0 'no' derived from the work scheduling autonomy scale (53), two items from the flexibility scale representing flexibility in terms of time (54) and two items based on the measure used in the Nurses Early Exit Study (NEXT) (11): "Does your roster have a fixed pattern?" and "Is it easy to swap shifts?". The latter four items were scored on a 5-point response scale and were dichotomized by median split so that the higher scores reflected 1 'yes' and the lower scores reflected 0 'no'. Factor analysis showed a three factor structure: control over work pace, control over starting and ending times and control over amount of days off. Because two of the subscales showed a low internal consistency and deleting items did not increase the reliability, it was decided to treat the items as belonging to one scale. 


\section{Ethical considerations}

The study was not submitted to an ethical committee because according to Dutch law (Wet Medisch-Wetenschappelijk Onderzoek met Mensen/Medical Research Involving Human Subjects Act), surveys only have to submitted to an ethical committee in a limited number of situations which do not apply to the current study. The study was approved by the management board of the nursing homes involved. The participants were informed by individual letter and an institutional newsletter, they were free to refuse to participate and welcomed to ask questions and express concerns about the study any time. Return of a completed questionnaire was taken to imply consent. Data were stored anonymously, treated confidentially and the participants' privacy was sufficiently guaranteed.

\section{Data analysis}

Data were analysed using IBM SPSS version 20. A frequency distribution of all different work patterns, and means and standard deviations of starting and ending times were computed. In order to develop a new typology, based on the five criteria mentioned in the introduction, the following contrasts were inspected: fixed shift pattern versus rotating shifts, nightshifts versus no nightshifts, and early shifts versus day shifts. The internal consistency of the scales was determined by Cronbach's alpha reliabilities. Descriptive statistics were computed for the independent and dependent variables. One-way ANOVAs with post-hoc analyses (Tukey), Chi-square and KruskalWallis tests were used to test for significant differences in the study variables between the new work schedule types. Where ANOVAs were used, post-hoc analyses (Tukey) were performed to test the differences. Where the Kruskal-Wallis test was used (e.g. level of education), post-hoc MannWhitney tests with Bonferroni correction (.05/10 tests: .005 level of significance) were performed to test differences between work schedule types.

\section{RESULTS}

The demographics of the nurses are shown in Table 1.

Table 1: Characteristics of nurses and schedules $(\mathrm{N}=498)$

\begin{tabular}{|c|c|c|c|c|}
\hline \multirow{2}{*}{\multicolumn{2}{|c|}{$\begin{array}{l}\text { Nurses' descriptives } \\
\text { Women }\end{array}$}} & \multicolumn{3}{|c|}{ Values } \\
\hline & & 483 & & $(96.8 \%)$ \\
\hline Age & Mean (SD) & 42.2 & years & $(S D=11,95)$ \\
\hline Nurse educational level* $(n=474)$ : & Mode & Level & 3 & \\
\hline Full-time contract & Amount (\%) & 28 & & $(5.7 \%)$ \\
\hline Job status (permanent) & Amount (\%) & 442 & & $(89.1 \%)$ \\
\hline Average years working in the current job & Mean (SD) & 9.2 & years & $(S D=8.1)$ \\
\hline Living together & Amount (\%) & 394 & & $(80.6 \%)$ \\
\hline Partner's job status (is working) $(n=408)$ & Amount (\%) & 362 & & $(88.7 \%)$ \\
\hline Partner has shiftwork (yes) & Amount (\%) & 91 & & $(26.1 \%)$ \\
\hline Average hours worked per week of partner & Mean (SD) & 37.7 & & $(S D=7.86)$ \\
\hline Having children living at home & Amount (\%) & 288 & & $(58.4 \%)$ \\
\hline Taking care of child<12 years & Amount (\%) & 163 & & $(32.9 \%)$ \\
\hline Days day care per week & Mean (SD) & 0.38 & days & $(S D=1.0)$ \\
\hline $\begin{array}{l}\text { Hours spent on care for family members per } \\
\text { week }\end{array}$ & Mean (SD) & 1.47 & hrs & $(S D=2.95)$ \\
\hline Minutes commuting time per workday & Mean (SD) & 37.7 & $\min$ & $(S D=26.5)$ \\
\hline \multicolumn{5}{|c|}{ Nurses' contribution to total household income } \\
\hline$<25 \%$ & & 77 & & $(16.2 \%)$ \\
\hline $25 \%-75 \%$ & & 312 & & $(64.9 \%)$ \\
\hline$>75 \%$ & & 91 & & $(18.9 \%)$ \\
\hline \multicolumn{5}{|l|}{ Work schedule descriptives } \\
\hline Average number of hours worked per week & Mean (SD) & 22.0 & hrs & $(S D=8.79)$ \\
\hline $\begin{array}{l}\text { Average number of overtime hours worked per } \\
\text { week }(n=469) \text { : }\end{array}$ & Mean (SD) & 3.0 & hrs & $(S D=4.66)$ \\
\hline Worked nights ( $n=462)$ : & Amount (\%) & 190 & & $(41.2 \%)$ \\
\hline $\begin{array}{l}\text { Average nights worked per month of those } \\
\text { working nights }\end{array}$ & Mean (SD) & 3.8 & nights & $(S D=2.97)$ \\
\hline Working weekends & Amount (\%) & 472 & & $(95 \%)$ \\
\hline $\begin{array}{l}\text { Average number per month of days worked } \\
\text { during weekends }\end{array}$ & Mean (SD) & 3.8 & days & $(S D=1.87)$ \\
\hline Start morning shift $(n=433)$ & Mean (SD) & 07:04 & AM & $(S D=0: 16 \mathrm{~min})$ \\
\hline End morning shift & Mean (SD) & $14: 42$ & PM & $(S D=1: 31 \mathrm{~min})$ \\
\hline Start afternoon shift $(n=397)$ & Mean (SD) & 14:58 & PM & $(S D=1: 11 \mathrm{~min})$ \\
\hline End afternoon shift & Mean (SD) & $22: 38$ & PM & $(S D=0: 50 \mathrm{~min})$ \\
\hline Start night shift $(n=204)$ & Mean (SD) & $22: 49$ & PM & $(S D=0: 14 \mathrm{~min})$ \\
\hline End night shift & Mean (SD) & 07:10 & AM & $(S D=0: 07 \mathrm{~min})$ \\
\hline
\end{tabular}

${ }^{*}$ The educational level was distinguished by five levels: L1: care helper level 1, L2: care helper level 2 , L3: care worker level 3, L4: nurse level 4 implying secondary vocational education, and L5: nurse level 5 implying higher vocational education. 
The final sample comprised mainly women, the mean age was 42.2 years (range 18-65), and $5.7 \%$ had full-time contracts (that is, 36 hours per week). The most common educational level was level 3 with qualification level 1 (care helper level 1) as the lowest and qualification level 5 (registered nurse) as the highest educational level. About half of the nurses had children living at home and one-third of the nurses had children under the age of twelve. A quarter of the nurses' partners worked in shifts.

The average number of shifts in the weekends of the $95 \%$ of nurses who worked weekends was 3.8 per month. The average number of night shifts of the $41.1 \%$ of nurses who worked nights was 3.8 per month. Noticeable are the large standard deviations of the starting times and ending times of the morning and the afternoon shifts, ranging from 50 until 91 minutes.

The socio-demographics of non-respondents $(n=476 ; 49 \%)$ were not significantly different from those of the participants (e.g. average number of hours and average number of overtime hours each week, income, type of position and sickness absence duration), except that the nonrespondents were younger; 37.5 years ( $S D=11.83$ years) $(p<0.01)$ versus 42.2 years $(S D=12.04$ years) of the respondents conducted with organizations' reports.

\section{New typology}

On the basis of our five criteria, a first draft typology was developed, consisting of eight types: Fixed shifts (frequency):

a) fixed early shifts $(9.2 \%)$,

b) fixed 'normal' day shifts (1\%),

c) fixed afternoon shifts $(5.8 \%)$, and

d) fixed night shifts (4.4\%).

Rotating shifts (frequency):

e) early in combination with afternoon shift (42.6\%),

f) early in combination with night shift (1.2\%)

g) afternoon in combination with night shift $(2.6 \%)$, and

h) rotating three shift pattern (33.1\%).

The (b), (c), (d) ( $f$ ) and (g) types of work schedules were reported by five, twenty-nine, twentyone, six and fourteen respondents respectively and therefore did not fulfil the fourth requirement formulated in the background. We finally distinguished five types that fulfilled all five requirements: Type 1: fixed early shift (a)

Type 2: rotating two shift pattern (early and afternoon shifts) (e)

Type 3: rotating three shift pattern (early, afternoon and night shifts) (h)

Type 4: fixed and rotating two shift pattern including night shift $(d, f, g)$

Type 5: fixed normal day or afternoon shifts (b, c).
Table 2: Work schedule characteristics of the different types of work schedules

\begin{tabular}{|c|c|c|c|c|c|c|c|c|c|}
\hline & \multicolumn{5}{|c|}{ Type of work schedule* } & \multirow[b]{2}{*}{ Total } & \multirow[b]{2}{*}{$F(\mathrm{df})$} & \multirow[b]{2}{*}{$p$} & \multirow[b]{2}{*}{$\begin{array}{r}\text { Post- } \\
\text { hoc }\end{array}$} \\
\hline & 1 & 2 & 3 & 4 & 5 & & & & \\
\hline $\begin{array}{l}\text { Prevalence of type of } \\
\text { schedule }\end{array}$ & $9.2 \%$ & $42.6 \%$ & $33.1 \%$ & $8.2 \%$ & $6.8 \%$ & $100 \%$ & & & \\
\hline $\begin{array}{l}\text { Average number of } \\
\text { hours worked per } \\
\text { week (SD) }\end{array}$ & $\begin{array}{l}22.9 \\
(8.46)\end{array}$ & $\begin{array}{l}20.3 \\
(8.75)\end{array}$ & $\begin{array}{l}25.7 \\
(8.02)\end{array}$ & $\begin{array}{l}19.1 \\
(8.18)\end{array}$ & $\begin{array}{l}17.1 \\
(7.26)\end{array}$ & $\begin{array}{l}22.0 \\
(8.79)\end{array}$ & $\begin{array}{l}F=14.135 \\
(4,482)\end{array}$ & $p=.000$ & $\begin{array}{l}2,4 \\
5<3\end{array}$ \\
\hline $\begin{array}{l}\text { Average number of } \\
\text { overtime hours per } \\
\text { week (SD) }\end{array}$ & $\begin{array}{l}3.3 \\
(5.8)\end{array}$ & $\begin{array}{l}2.8 \\
(4.43)\end{array}$ & $\begin{array}{l}3.1 \\
(4.67)\end{array}$ & $\begin{array}{l}2.5 \\
(4.57)\end{array}$ & $\begin{array}{l}3.1 \\
(4.48)\end{array}$ & $\begin{array}{l}2.95 \\
(4.66)\end{array}$ & $\begin{array}{l}F=.263 \\
(4,463)\end{array}$ & $p=.902$ & \\
\hline $\begin{array}{l}\text { Days off between } \\
\text { shifts (SD) }\end{array}$ & $\begin{array}{l}2.5 \\
(1.21)\end{array}$ & $\begin{array}{l}2.6 \\
(1.25)\end{array}$ & $\begin{array}{l}2.2 \\
(.86)\end{array}$ & $\begin{array}{l}5.0 \\
(2.88)\end{array}$ & $\begin{array}{l}3.1 \\
(2.59)\end{array}$ & $\begin{array}{l}2.7 \\
(1.62)\end{array}$ & $\begin{array}{l}F=28.287 \\
(4,465)\end{array}$ & $p=.000$ & $3<5<4$ \\
\hline $\begin{array}{l}\text { Knowing work } \\
\text { schedule at least } 2 \\
\text { weeks in advance }\end{array}$ & $100.0 \%$ & $91 \%$ & $93.9 \%$ & $92.5 \%$ & $96.9 \%$ & $93.3 \%$ & $X^{2}=5.668 ;$ & $p=.225$ & \\
\hline
\end{tabular}

*: 1 = fixed early shifts; 2 = rotating 2-shift (early and afternoon shifts); 3 = rotating 3-shift (early. afternoon and night shifts); $4=$ fixed nightshift or 2-shifts including night shift and $5=$ fixed shifts normal day or afternoon shifts.

Because almost all nurses worked weekends, no distinction was made between working weekends or weekdays. As can be seen in Table 2, the most prevalent type of work schedule was the type 2 schedule (early and afternoon two shift schedule) followed by the type 3 schedule (rotating three shift schedule).

\section{Differences between the five types}

As can be seen in Table 2, there were noticeable differences between the types of work schedules. The average number of hours worked per week differed significantly between nurses working in the different types of schedules. Nurses with type 3 schedules worked on average substantially more hours than nurses with the type 2, 4 and 5 schedules. Overtime hours per week did not differ among nurses with different types of work schedules. Days off between two series of shifts as an indicator of the possibility to recover or to take a rest differed significantly between nurses in the five types of work schedules; nurses with type 3 schedules had fewer days off than those with type 4 and 5 schedules. No differences between the five types of work schedules were found regarding the moment nurses were informed about their work schedules. 
Table 3: Socio-demographic and family characteristics of the nurses working in the different types of work schedules (\% and mean (SD))

\begin{tabular}{|c|c|c|c|c|c|c|c|c|c|}
\hline & \multicolumn{5}{|c|}{ Type of work schedule* } & \multirow[b]{2}{*}{ Total } & & \multirow[b]{2}{*}{$p$} & \multirow[b]{2}{*}{ Post-hoc } \\
\hline & 1 & 2 & 3 & 4 & 5 & & & & \\
\hline Sex (female) & $89,1 \%$ & $97.2 \%$ & $97.6 \%$ & $100 \%$ & $97.1 \%$ & $96.8 \%$ & $X^{2}=10.39$ & $p=.034$ & \\
\hline Age years (SD) & $\begin{array}{l}47.8 \\
(9.7)\end{array}$ & $\begin{array}{l}42.9 \\
(12.2)\end{array}$ & $\begin{array}{l}37.7 \\
(11.7)\end{array}$ & $\begin{array}{l}47.3 \\
(8.3)\end{array}$ & $\begin{array}{l}46.1 \\
(10.9)\end{array}$ & $\begin{array}{l}42.2 \\
(11.9)\end{array}$ & $\begin{array}{l}F=12.232 \\
(4,488)\end{array}$ & $p=.000$ & $3<1,4,5$ \\
\hline Nurse educational level** & & & & & & & $X^{2}(4)=31.510$ & $p=.000$ & $1,2<3$ \\
\hline$L 1$ & $7.0 \%$ & $8.4 \%$ & $0 \%$ & $7.7 \%$ & $0 \%$ & $4.9 \%$ & & & \\
\hline$L 2$ & $27.9 \%$ & $25.7 \%$ & $6.8 \%$ & $10.3 \%$ & $13.8 \%$ & $17.5 \%$ & & & \\
\hline$L 3$ & $46.5 \%$ & $54.0 \%$ & $75.2 \%$ & $66.7 \%$ & $65.5 \%$ & $62.2 \%$ & & & \\
\hline$\angle 4$ & $14.0 \%$ & $9.9 \%$ & $16.1 \%$ & $12.8 \%$ & $13.8 \%$ & $12.9 \%$ & & & \\
\hline$L 5$ & $4.7 \%$ & $2.0 \%$ & $1.9 \%$ & $2.6 \%$ & $6.9 \%$ & $2.5 \%$ & & & \\
\hline $\begin{array}{l}\text { Average years working in } \\
\text { the current job }\end{array}$ & $\begin{array}{l}10.7 \\
(9.45)\end{array}$ & $\begin{array}{l}9.6 \\
(8.07)\end{array}$ & $\begin{array}{l}6.8 \\
6.92)\end{array}$ & $\begin{array}{l}12.5 \\
(9.06)\end{array}$ & $\begin{array}{l}11.7 \\
(8.13)\end{array}$ & $\begin{array}{l}9.2 \\
(8.13)\end{array}$ & $\begin{array}{l}F=6.811 \\
(4,489)\end{array}$ & $p=.000$ & $3<1,2,4,5$ \\
\hline Job status (\% permanent) & $93.5 \%$ & $86.3 \%$ & $88.4 \%$ & $95.1 \%$ & $97.1 \%$ & $89.1 \%$ & $X^{2}=6.487$ & $p=.166$ & \\
\hline Living together (yes) & $82.6 \%$ & $79.3 \%$ & $77.6 \%$ & $90.2 \%$ & $88.2 \%$ & $80.6 \%$ & $X^{2}=6.716$ & $p=.568$ & \\
\hline $\begin{array}{l}\text { Partner's job status (is } \\
\text { working) }\end{array}$ & $76.3 \%$ & $89.9 \%$ & $91.8 \%$ & $83.8 \%$ & $90.0 \%$ & $88.7 \%$ & $X^{2}=8.290$ & $p=.082$ & \\
\hline $\begin{array}{l}\text { Partner has shiftwork } \\
\text { (yes) }\end{array}$ & $17.2 \%$ & $22.8 \%$ & $30.5 \%$ & $32.3 \%$ & $26.9 \%$ & $26.1 \%$ & $X^{2}=3.829$ & $p=.430$ & \\
\hline $\begin{array}{l}\text { Average hours worked } \\
\text { per week of partner (SD) }\end{array}$ & $\begin{array}{l}37.2 \\
(5.46)\end{array}$ & $\begin{array}{l}36.9 \\
(9.72)\end{array}$ & $\begin{array}{l}38.2 \\
(6.71)\end{array}$ & $\begin{array}{l}38.2 \\
(2.82)\end{array}$ & $\begin{array}{l}38.8 \\
(7.47)\end{array}$ & $\begin{array}{l}37.7 \\
(7.86)\end{array}$ & $\begin{array}{l}F=.663 \\
(4,330)\end{array}$ & $p=.618$ & \\
\hline $\begin{array}{l}\text { Taking care of } \\
\text { children }<12 \text { years (yes) }\end{array}$ & $23.9 \%$ & $37.4 \%$ & $28.7 \%$ & $36.6 \%$ & $32.4 \%$ & $32.9 \%$ & $X^{2}=5.250$ & $p=.263$ & \\
\hline $\begin{array}{l}\text { Days day care per week } \\
\text { (SD) }\end{array}$ & $\begin{array}{l}0.18 \\
(0.72)\end{array}$ & $\begin{array}{l}0.48 \\
(1.11)\end{array}$ & $\begin{array}{l}0.38 \\
(1.0)\end{array}$ & $\begin{array}{l}0.23 \\
(0.74)\end{array}$ & $\begin{array}{l}0.24 \\
(0.82)\end{array}$ & $\begin{array}{l}0.38 \\
(1.0)\end{array}$ & $\begin{array}{l}F=1.388 \\
(4,482)\end{array}$ & $p=.237$ & \\
\hline $\begin{array}{l}\text { Hours spent on care for } \\
\text { family members per } \\
\text { week (SD) }\end{array}$ & $\begin{array}{l}2.1 \\
(4.3)\end{array}$ & $\begin{array}{l}1.30 \\
(2.31)\end{array}$ & $\begin{array}{l}1.43 \\
(3.18)\end{array}$ & $\begin{array}{l}1.97 \\
(3.27)\end{array}$ & $\begin{array}{l}1.34 \\
(2.75)\end{array}$ & $\begin{array}{l}1.47 \\
(2.95)\end{array}$ & $\begin{array}{l}F=.979 \\
(4,481)\end{array}$ & $p=.418$ & \\
\hline $\begin{array}{l}\text { Minutes commuting time } \\
\text { per workday (SD) }\end{array}$ & $\begin{array}{l}28.0 \\
(24.2)\end{array}$ & $\begin{array}{l}37.7 \\
(26.2)\end{array}$ & $\begin{array}{l}40.9 \\
(27.0)\end{array}$ & $\begin{array}{l}31.6 \\
(19.4)\end{array}$ & $\begin{array}{l}44.0 \\
(32.7)\end{array}$ & $\begin{array}{l}37.7 \\
(26.5)\end{array}$ & $\begin{array}{l}F=3.142 \\
(4,481)\end{array}$ & $p=.014$ & $3>1$ \\
\hline $\begin{array}{l}\text { Nurses' contribution to } \\
\text { total household income }\end{array}$ & & & & & & & $X^{2}(4)=15.015$ & $p=.005$ & $3>2$ \\
\hline$<25 \%$ & $17.8 \%$ & $21.8 \%$ & $6.9 \%$ & $14.6 \%$ & $24.2 \%$ & $16.0 \%$ & & & \\
\hline $25 \%-75 \%$ & $57.8 \%$ & $59.4 \%$ & $73.0 \%$ & $75.6 \%$ & $57.6 \%$ & $65.0 \%$ & & & \\
\hline$>75 \%$ & $24.4 \%$ & $18.8 \%$ & $20.1 \%$ & $9.8 \%$ & $18.2 \%$ & $19.0 \%$ & & & \\
\hline
\end{tabular}

*: 1 = fixed early shifts; 2 = rotating 2-shift (early and afternoon shifts); 3 = rotating 3-shift (early. afternoon and night $*: 1=$ fixed early shifts; $2=$ rotating 2 -shift (early and afternoon shifts); $3=$ rotating 3-shift (early. afternoon and
shifts); $4=$ fixed nightshift or 2 -shifts including night shift and $5=$ fixed shifts normal day or afternoon shifts. ${ }^{* *}=L 1=$ care helper level $1, L 2=$ care helper level $2, L 3=$ care worker level $3, L 4=$ nurse level 4 implying secondary vocational education, $L 5=$ nurse level 5 implying higher vocational education.

As can be seen in Table 3, there were a number of significant differences with respect to the socio-demographic and family characteristics. The amount of women working in the types of work schedule and the age of nurses working in the different types of schedules differed. Nurses with type 3 schedules were significantly younger than nurses with other types of work schedules, except for nurses with type 2 schedules. Educational level differed significantly. Nurses with type 1 and type 2 schedules had lower educational levels than nurses in type 3 schedules. The average years that nurses worked in the current job differed between the nurses; nurses with type 3 schedules worked considerably less years in the current job than nurses in the other type of schedules. Living with a partner, having an employed partner or not, the average number of their partners' work hours per week, having a partner with shiftwork or not, taking care of children under the age of twelve, number of days children spent in day care per week, number of hours spent on care for family members per week did not differ between the types. Commuting time per workday differed significantly. Nurses with type 3 schedules had more commuting minutes per workday than nurses with type 1 schedules. Nurses with type 3 contributed more to the total household income than nurses with type 2 .

With respect to the appraisal of the work schedule, it can be seen in Table 4 that satisfaction with the work schedule differed significantly. Nurses with type 3 were less satisfied with their work schedule than nurses with type 4 schedules. Finally, the work schedule control differed. The nurses with type 3 schedules experienced considerable less control over their work schedule than all other nurses except for nurses with type 4 schedules.

Table 4: Nurses' appraisal of the different types of work schedules

\begin{tabular}{llllllllllll}
\hline & \multicolumn{1}{c}{ Type of work schedule* } & & & & \\
\cline { 2 - 7 } & $\mathbf{1}$ & $\mathbf{2}$ & $\mathbf{3}$ & $\mathbf{4}$ & $\mathbf{5}$ & Total & $\boldsymbol{F}$ (df) & $\boldsymbol{p}$ & $\begin{array}{c}\text { Post- } \\
\text { hoc }\end{array}$ \\
\hline Satisfaction with work schedule & 3.7 & 3.56 & 3.4 & 3.75 & 3.75 & 3.54 & $F=4.012$ & $\boldsymbol{p}=. \mathbf{0 0 3}$ & $3<4$ \\
(Mean (SD))(score 1-5)** & $(.42)$ & $(.59)$ & $(.57)$ & $(.71)$ & $(.48)$ & $(.59)$ & $(4,447)$ & & \\
Work schedule control & .48 & .37 & .30 & .36 & .46 & .36 & $F=8.108$ & $\boldsymbol{p}=.000$ & $3<1,2,5$ \\
(Mean (SD)) (score 0-1)*** & $(.29)$ & $(.21)$ & $(.21)$ & $(.17)$ & $(.24)$ & $(.22)$ & $(4,480)$ & & \\
\hline
\end{tabular}

$*: 1$ = fixed early shifts; 2 = rotating 2-shift (early and afternoon shifts); 3 = rotating 3-shift (early. afternoon and nigh shifts); $4=$ fixed nightshift or 2-shifts including night shift and $5=$ fixed shifts normal day or afternoon shifts.

** : : Higher values indicate more satisfaction with irregular working hours

*** : Higher values indicate more work schedule control

\section{DISCUSSION}

This paper presents a new typology of work schedules based on data of 498 nurses working in elderly care institutions in the Netherlands. This new typology could improve research on work schedules. Based on predetermined criteria and frequencies of all possible working schedules found in this sample $(n=24)$ a new typology of work schedules consisting of five types is proposed. Next, the differences between the five types in terms of schedule characteristics, nurses' characteristics (socio-demographics and family characteristics) and appraisal of the work schedule were studied. A considerable amount of differences between the types of schedules was found regarding work schedule characteristics, the nurses' socio-demographic characteristics and nurses' appraisal of the work schedule. 


\section{The new typology of nursing work schedules}

There is a need for a more sophisticated typology (6) which also better represents the increasing diversity in work schedules over time $(2,3,29)$. We think that the new typology found in this study, is an improvement because it takes into account the most frequently reported types of work schedules and moreover, these types differ regarding work schedule characteristics, nurse characteristics and appraisal of the work schedule. The new typology of schedules introduced in this study is based, as a starting point, on the most prevalent and more traditional two and three rotating schedules. Next, fixed shifts are distinguished. The new typology is meaningful for practice, because it seems to also represent differences regarding the nurses who work in the different types and their appraisals of the work schedules. Besides the distinction between weekends and nonweekends, which is not used in our typology, Our typology parallels the frequencies of different types reported in other research $(18,19,37)$.

\section{Differences between the five types}

Using this new typology, important differences were detected between the nurses working in the five types of schedules, which further validates the new typology. The work of nurses with type 3 schedules (with a rotating three shift pattern) was - in agreement with other research characterized by more negative features than the work of nurses in other schedules $(11,22,32$, 55). These nurses were least satisfied with their work schedule as was also found in other research (11), and they were even less satisfied than a comparable group of nurses in another study (42). It seems that in the experience of the nurses, the three shift schedule has more disadvantages than a two shift schedule. Furthermore, they indicated to have the least control over their work schedule. This is probably due to the rotating pattern which makes it more difficult to swap shifts and to schedule starting and ending times. These findings confirm the importance of including the appraisal of the work schedule in this study and in future research.

Nurses with the type 3 schedules worked the most hours on average, commuted the most minutes per workday and had the fewest days off in between shifts. Having days off is normally seen as an opportunity to recover from work $(29,56,57)$ and more commuting hours could limit the available time to recover. Furthermore, these nurses were on average the youngest group and worked on average the least years in the current job which, in line with the conclusion of Winwood et al. (55), could indicate (Winwood, et al., 2006)that younger, inexperienced nurses working in type 3 schedules may require greater support from their organization, even though in our case their mean age was already 37 years. Nurses working in type 1, 4 and 5 schedules were on average about 10 years older.

Nurses with other types of work schedules than type 3 also have some noticeable characteristics. Nurses working in type 1 schedules appeared to have lower commuting time per workday than nurses working in type 2 schedules and they experienced higher work schedule control than nurses working in a type 3 schedule. Nurses working in type 2 schedule differed from nurses working in type 1 schedule because they work fewer hours on average per week. Possibly, the type 2 schedule offers more room for nurses to adjust the schedule to their preferences (58). The main difference between nurses in these types of schedule and nurses working in type 4 schedules was that the work of nurses in type 4 schedules was characterised by higher satisfaction with work schedule and more days off between shifts. Nurses with type 4 and 5 schedules were comparable except for the latter being characterized by experiencing higher work schedule control. Type 4 schedule was characterized by fixed nightshifts and obviously these nurses had less room to adjust their work schedule than nurses working in type 5 shifts with fixed normal day of afternoon shifts.

\section{Different career stages?}

Taking the above results into further consideration, the current findings regarding age differences across the different types of work schedule is striking and do not seem to reflect the variety in family responsibilities between life stages. They might represent a specific career pattern. It might be that younger nurses prefer to start their careers with type 3 schedules, either because of primary or self-selection $(15,59)$, their organization's advice, or because of the higher wages, which could be preferable in this stage of life. With increasing age, they probably want to change to a less demanding type of schedule (60), because they might have trouble tolerating shiftwork $(29,61)$. This might explain why the type 5 schedule is characterized by a higher prevalence of older, level 5 nurses who work less hours compared to nurses with type 3 schedules.

\section{Limitations}

The criteria for the new typology were sufficient to construct a typology, which reveals differences between nurses working in different types of shifts. Response was moderate to high (51\%) and the respondents were comparable with Dutch elderly care nurses in general regarding age, sex, average work week and number of years at the current job (3). The respondents were thus representative for the residential elder care population they came from, except that non-respondents were slightly younger than respondents were. It can thus be concluded that selective dropout is not a serious problem in the present study. The nurses included in this research are representative for nurses working in residential elder care in the Netherlands who work largely across 8 hour shifts. Countries vary in their shift length. Although twelve-hour shifts are increasingly used across Europe (36), they are not common in the Netherlands, Belgium, Germany, Greece, Norway, and Sweden (62) Our typology could therefore be generalizable to those countries. Generalizations of our typology to countries with nurses working in twelve-hour shifts (e.g. England, Ireland, and Poland) should be made with care. The possibility exists that using the same method could produce a altered typology of work schedule. 
Because we limited the number of different types of work schedules for reasons of feasibility, employees with slightly different work schedules might have been classified in the same type. In practice, one should not forget that for an individual employee, a one hour difference in starting times could be a meaningful difference in relation to bringing children to school or allowing for more sleep (63). Type 4 work schedules contained both fixed and rotating shifts, including nightshifts These were combined because they all contained night shifts. Research by Demerouti et al. (64) showed that employees with rotating shifts reported less job satisfaction than employees working in fixed shifts. This might have led to a slight underestimation of the differences between type 4 and the other types.

Considering the scales used, the Cronbach's alpha reliability of the Satisfaction with Irregular Working times was good (Cronbach's alpha 0.92) and of the work schedule control scale was sufficient (Cronbach's alpha 0.66) (65). For ANOVA's with five groups, power should be sufficient in the present study $(66,67)$.

\section{CONCLUSION}

All in all, it is possible to distinguish five main types of work schedules among nurses working in residential elder care in the Netherlands. A considerable amount of differences was found between the types of schedules regarding work schedule characteristics, the nurses' socio-demographic characteristics and the nurses' appraisal of the work schedule. This indicates sufficient construct validity of the new typology. The new typology seems useful to classify shifts on a more detailed level, which is of utmost importance for research and might be useful for employers as well.

\section{Practical and scientific implications}

The present typology of nurses' work schedules is based on empirical research and seems a promising typology for research regarding work-related health and employability. To get an even more precise picture, research focusing on the health-related characteristics of the nurses working in the different types might be useful.

It would be valuable to validate the typology in other health care professions with shift work and to develop a new typology for nurses working twelve-hour shifts.

The new typology may not only be useful for researchers because of its conciseness, but also for employers and nursing managers for monitoring nurses' employability. However further longitudinal research is warranted to elucidate whether, how and why nurses change work schedule types during their careers and if so, what the consequences are.

\section{Acknowledgements}

We would like to acknowledge the participating nursing homes for their collaboration and to thank all the nurses who participated in this study.

\section{REFERENCES}

1. Flinkman M, Laine M, Leino-Kilpi H, Hasselhorn HM, Salanterä S. Explaining young registered Finnish nurses' intention to leave the profession: A questionnaire survey. International Journal of Nursing Studies. 2008;45(5):727-39

2. Haanstra-Veldhuis V, De Zwart BCH. Flexibilisering en werkbeleving in de vvt-sector: onderzoek onder medewerkers in de verzorging \& verpleging en thuiszorg. 2013.

3. AZWinfo. Arbeid in Zorg en Welzijn 2010. Zoetermeer: Panteia2011.

4. Hayes LJ, O'Brien-Pallas L, Duffield C, Shamian J, Buchan J, Hughes F, et al. Nurse turnover: a literature review - an update. International Journal of Nursing Studies. 2012 Jul;49(7):887-905.

5. Rosa R, Colligan M. Plain language about shiftwork. Cincinnati, $\mathrm{OH}$ : Department of Health and Human Services, Public Health Service, Centers for Disease Control and Prevention, National Institute for Occupational Safety and Health, Division of Biomedical and Behavioral Science, (NIOSH); 1997.

6. Merkus SL, van Drongelen A, Holte KA, Labriola M, Lund T, van Mechelen W, et al. The association between shift work and sick leave: a systematic review. Occupational and Environmental Medicine. [Research Support, Non-U.S. Gov't Review]. 2012 Oct;69(10):701-12.

7. Knutsson A. Methodological Aspects of Shift-Work Research. Chronobiology International: The Journal of Biological and Medical Rhythm Research. 2004;21(6):1037 - 47.

8. Tucker $\mathrm{P}$, Folkard $\mathrm{S}$. Working time, health, and safety : A research synthesis paper. Geneva: International Labour Office2012.

9. Simon M, Tackenberg P, Nienhaus A, Estryn-Behar M, Conway PM, Hasselhorn HM. Back or neck-painrelated disability of nursing staff in hospitals, nursing homes and home care in seven countries--results from the European NEXT-Study. International Journal of Nursing Studies. [Comparative Study Research Support, Non-U.S. Gov't]. 2008 Jan;45(1):24-34.

10. Hellenthal A. Verpleegkundigen aan het werk [nurses at work]. Voorburg?Heerlen: Statistics Netherlands 2012.

11. Hasselhorn H-M, Oginska H, Tackenberg P, Pokorski J, Estryn-Behar M, Camerino D, et al. Nurses Early Exit Study - (NEXT) - scientific results. Wuppertal: University of Wuppertal2005.

12. Åkerstedt T, Kecklund G. The future of work hours--the European view. Industrial Health. 2005 Jan;43(1):80-4.

13. Caroly S. How police officers and nurses regulate combined domestic and paid workloads to manage schedules: a gender analysis. Work. 2011;40 Suppl 1:S71-82.

14. Lee S, McCann D, Messenger JC. Working Time Around the World: Trends in working hours, laws, and policies in a global comparative perspective. London and Geneva: Routledge and IL02007.

15. Totterdell P. Work schedules. In: Barling J, Kelloway E, Frone M, editors. Handbook of Work Stress. London: Sage; 2005.

16. Caruso CC, Bushnell T, Eggerth D, Heitmann A, Kojola B, Newman K, et al. Long working hours, safety, and health: toward a National Research Agenda. Am J Ind Med. 2006 Nov;49(11):930-42.

17. Barton J, Spelten E, Totterdell P, Smith L, Folkard S, Costa G. The Standard Shiftwork Index: a battery of questionnaires for assessing shiftwork-related problems. Work \& Stress. 1995 1995/01/01;9(1):4-30

18. Blau G, Lunz M. Testing the Impact of Shift Schedules on Organizational Variables. Journal of Organizational Behavior. 1999;20(6):933-42. 
19. Barker LM, Nussbaum MA. Fatigue, performance and the work environment: a survey of registered nurses. Journal of Advanced Nursing. 2011 Jun;67(6):1370-82.

20. Kandolin I. Burnout of female and male nurses in shiftwork. Ergonomics. 1993 Jan-Mar;36(1-3):141-7.

21. Kleiven M, Boggild $H$, Jeppesen HJ. Shift work and sick leave. Scandinavian Journal of Work, Environment \& Health. 1998;24 Suppl 3:128-33.

22. Sveinsdottir $H$. Self-assessed quality of sleep, occupational health, working environment, illness experience and job satisfaction of female nurses working different combination of shifts. Scandinavian journal of caring sciences. 2006 Jun;20(2):229-37.

23. Wilson JL. The impact of shift patterns on healthcare professionals. Journal of Nursing Management. 2002;10(4):211-9.

24. Tucker P, Knowles SR. Review of studies that have used the Standard Shiftwork Index: evidence for the underlying model of shiftwork and health. Applied ergonomics. 2008 Sep;39(5):550-64.

25. Monk TH. What Can the Chronobiologist Do to Help the Shift Worker? Journal of Biological Rhythms. 2000 April 1, 2000;15(2):86-94.

26. Barthe B, Messing K, Abbas L. Strategies used by women workers to reconcile family responsibilities with atypical work schedules in the service sector. Work. [Research Support, Non-U.S. Gov't]. 2011;40 Suppl 1:S47-58.

27. Geiger-Brown J, Trinkoff A, Rogers VE. The Impact of Work Schedules, Home, and Work Demands on Self-Reported Sleep in Registered Nurses. Journal of Occupational and Environmental Medicine. [Article]. 2011 Mar;53(3):303-7.

28. Dorrian J, Tolley C, Lamond N, van den Heuvel C, Pincombe J, Rogers AE, et al. Sleep and errors in a group of Australian hospital nurses at work and during the commute. Applied Ergonomics. 2008;39(5):605-13.

29. Härmä M. Workhours in relation to work stress, recovery and health. Scandinavian Journal of Work, Environment \& Health. 2006 Dec;32(6):502-14

30. Åkerstedt T. Shift work and disturbed sleep/wakefulness. Occupational Medicine. 2003 March 1 , 2003;53(2):89-94.

31. Burch JB, Tom J, Zhai YS, Criswell L, Leo E, Ogoussan K. Shiftwork impacts and adaptation among health care workers. Occup Med-Oxf. [Article]. 2009 May;59(3):159-66.

32. Muecke S. Effects of rotating night shifts: literature review. Journal of Advanced Nursing. 2005 May;50(4):433-9.

33. Smith M, Eastman C. Shift work: health, performance and safety problems, traditional countermeasures, and innovative management strategies to reduce circadian misalignment. Nature and Science of Sleep. 2012;4:111-32.

34. Costa G. The problem: Shiftwork. Chronobiology International. [Article]. 1997;14(2):89-98

35. Sallinen $M$, Kecklund $G$. Shift work, sleep, and sleepiness - differences between shift schedules and systems. Scand J Work Environ Health. 2010 Mar;36(2):121-33.

36. Estryn-Behar M, Van der Heijden BI. Effects of extended work shifts on employee fatigue, health, satisfaction, work/family balance, and patient safety. Work. 2012;41 Suppl 1:4283-90.

37. Staines GL, Pleck JH. Nonstandard work schedules and family life. Journal of Applied Psychology. 1984;69(3):515-23.
38. Trinkoff AM, Johantgen M, Storr CL, Gurses AP, Liang $Y$, Han K. Nurses' work schedule characteristics, nurse staffing, and patient mortality. Nursing Research. [Research Support, Non-U.S. Gov't]. 2011 JanFeb;60(1):1-8.

39. Bøggild H, Burr H, Tüchsen F, Jeppesen HJ. Work environment of Danish shift and day workers. Scandinavian Journal of Work, Environment \& Health. 2001;27(2):97-105

40. Trinkoff AM, Geiger-Brown J, Brady B, Lipscomb J, Muntaner C. How long and how much are nurses now working? Am J Nurs. 2006 Apr;106(4):60-71, quiz 2.

41. Marinaccio A, Ferrante P, Corfiati M, Di Tecco C, Rondinon B, Bonafede M, et al. The relevance of sociodemographic and occupational variables for the assessment of work-related stress risk. BMC Public Health 2013;12(1):1157-66.

42. Peters V, De Rijk AE, Boumans NP. Nurses' satisfaction with shiftwork and associations with work, home and health characteristics: a survey in the Netherlands. J Adv Nurs. 2009 Dec;65(12):2689-700.

43. Holtom BC, Lee TW, Tidd ST. The relationship between work status congruence and work-related attitudes and behaviors. Journal of Applied Psychology. 2002;87(5):903-15.

44. Ogińska H, Camerino D, Estryn-Behar M, Pokorski J. Work schedules of nurses in Europe. In: Hasselhorn H-M, Tackenberg P, Müller BH, editors. Working conditions and intent to leave the profession among nursing staff in Europe. Wuppertal: University of Wuppertal; 2003. p. 82-8.

45. Taht K, Mills M. Nonstandard Work Schedules, Couple Desynchronization, and Parent-Child Interaction: A Mixed-Methods Analysis. Journal of Family Issues. [Article]. 2012 Aug;33(8):1054-87.

46. Fagan C, Lyonette C, Smith M, Saldaña-Tejeda A. The influence of working time arrangements on work-life integration or 'balance': A review of the international evidence. Geneva: International Labour Office2012.

47. Perrewé PL, Zellars KL. An Examination of Attributions and Emotions in the Transactional Approach to the Organizational Stress Process. Journal of Organizational Behavior. 1999;20(5):739-52.

48. Nabe-Nielsen K, Kecklund G, Ingre M, Skotte J, Diderichsen F, Garde AH. The importance of individual preferences when evaluating the associations between working hours and indicators of health and well-being. Applied Ergonomics. 2010;41(6):779-86.

49. Galatsch M, Li J, Derycke H, Muller BH, Hasselhorn HM. Effects of requested, forced and denied shift schedule change on work ability and health of nurses in Europe -Results from the European NEXT-Study. BMC Public Health. 2013 Dec 5;13(1):1137.

50. Van Rijswijk K. It's about time: Part-time, flex-time and a healthy work-home balance. Tilburg Tilburg University; 2006.

51. Ala-Mursula L, Vahtera J, Kivimäki M, Kevin M, Pentti J. Employee control over working times: associations with subjective health and sickness absences. Journal of Epidemiology and Community Health. 2002 April 2002;56(4):272-8.

52. Krausz M, Sagie A, Bidermann Y. Actual and Preferred Work Schedules and Scheduling Control as Determinants of Job-Related Attitudes. Journal of Vocational Behavior. 2000;56(1):1-11.

53. Janssen $\mathrm{N}$. The natural course of fatigue in a working population [Maastricht] : UPM, Universitaire Pers Maastricht; Maastricht : University Library, Maastricht University 2004.

54. Shockley KM, Allen TD. When flexibility helps: Another look at the availability of flexible work arrangements and work-family conflict. Journal of Vocational Behavior. 2007;71(3):479-93. 
55. Winwood PC, Winefield AH, Lushington K. Work-related fatigue and recovery: the contribution of age, domestic responsibilities and shiftwork. Journal of Advanced Nursing. 2006;56(4):438-49.

56. Totterdell P, Spelten E, Smith L, Barton J, Folkard S. Recovery from work shifts: How long does it take? Journal of Applied Psychology. 1995;80(1):43-57.

57. Silva-Costa A, Griep RH, Fischer FM, Rotenberg L. Need for recovery from work and sleep-related complaints among nursing professionals. Work. [Research Support, N.I.H., Extramural Research Support, Non-U.S. Gov't]. 2012;41 Suppl 1:3726-31

58. Morgan PA, Merrell JA, Rentschler D. Midlife mothers favor 'being with' children over work and careers. Work. 2014 Sep 23.

59. Axelsson J, Kecklund G, Gustavsson P, Rudman A, editors. Selection into shift and night work. 20th International Symposium on Shiftwork and Working Time; "Biological mechanisms and risk management in the 24h society"; 2011; Stockholm, Sweden.

60. Smith EL. How are nurses at risk? Work. 2012;41 Suppl 1:1911-9.

61. Costa G, Sartori S. Ageing, working hours and work ability. Ergonomics. 2007 Nov;50(11):1914-30.

62. Griffiths P, Dall'Ora C, Simon M, Ball J, Lindqvist R, Rafferty AM, et al. Nurses' shift length and overtime working in 12 European countries: the association with perceived quality of care and patient safety. Med Care. 2014 Nov:52(11):975-81.

63. Ruggiero JS, Pezzino JM. Nurses' perceptions of the advantages and disadvantages of their shift and work schedules. The Journal of nursing administration. 2006 0ct;36(10):450-3.

64. Demerouti E, Geurts SA, Bakker AB, Euwema M. The impact of shiftwork on work--home conflict, job attitudes and health. Ergonomics. 2004 Jul 15;47(9):987-1002.

65. Cortina JM. What is coefficient alpha? An examination of theory and applications. Journal of Applied Psychology. 1993;78(1):98-104.

66. Wilson Van Voorhis CR, Morgan BL. Understanding Power and Rules of Thumb for Determining Sample Sizes. Tutorials in Quantitative Methods for Psychology. 2007;3(2):43-50.

67. Cohen J. A power primer. Psychological Bulletin. 1992;112(1):155-9. 


\section{ABSTRACT}

Purpose There is scarce research on age and sustainable employability of nurses working in various types of work schedules. Earlier research showed that nurses working in work schedules differ regarding age. Different operationalisations of age might explain variations in sustainable employability. Therefore, the aim of this study was to investigate how nurses working in various types of work schedule differ regarding sustainable employability, and the role that age plays in these differences. Age was defined as chronological age, organisational age, life-span age, and functional age.

Method Questionnaires were distributed to 974 Dutch nurses in residential elder care (response rate $51 \%$ ) with questions about the type of work schedule, aspects of sustainable employability various operationalisations of age, and registered sickness absence data were used.

Results Nurses working in various types of work schedules differed regarding aspects of sustainable employability, also when operationalisations of age were added. The 'life-span age' was directly related to aspects of sustainable employability. Statistically, work ability and job satisfaction were only explained by varying operationalisations of age.

Conclusions Nurses' sustainable employability appeared to be mainly related to differences between the types of work schedule rather than age. Fixed early shifts are characterised by the most positive aspects of sustainable employability, and three rotating schedules score worst. To improve sustainable employability, organisations should implement a system in which nurses with different types of work schedule are monitored in combination with their life-span perspective.

\section{INTRODUCTION}

The shortage of nurses due to an ageing nursing workforce is an increasing problem in the Netherlands and globally (1-3). This suggests that more attention should be paid to sustainable employability of the nursing workforce (4). Sustainable employability is defined as employees having the opportunity to perform work with the preservation of health and well-being during their working life, now and in the future (5). Possible determinants of nurses' sustainable employability could be found in personal and occupational characteristics (6-10).

Work schedules and working hours warrant specific attention, because both are linked to a wide range of negative consequences, e.g. self-rated health, fatigue, work-home interference, job satisfaction, decline in performance, and sick leave (11-18). Moreover, work schedules and working hours are high on the list of factors that contribute to nurses leaving the profession (19-21). An increasing variety in types of work schedules has arisen due to the preferences of both employers and employees $(16,22-24)$. This variety enlarges the need for a new, distinct typology to detect differences with respect to (negative) consequences (25).

To understand the contemporary variety in work schedules, a new evidence-based typology was developed based on both scientific literature (26-28) and empirical findings (29). The newly developed typology shows sufficient construct validity and seems useful to classify the shifts on a more detailed level. Using this new typology of five types of work schedule, differences were found between nurses working in the types of schedules regarding their work schedule characteristics, socio-demographic characteristics, and their work schedule appraisal. The schedule with three rotating shifts appeared to be the most unfavourable, as also reported by others $(3,18,30,31)$; it was characterized by more negative features including a high number of working hours, few days off between the shifts, less satisfaction with the work schedule, and a low amount of work schedule control (29).

Chronological age also appeared to differ between the types of work schedule $(29)(29,30)$. Nurses with three rotating shifts had an average age of 38 years and were significantly younger than nurses with other types of work schedule (mean age 46-48 years), except for nurses with two rotating schedules (29). This finding might represent a specific career pattern or selection process during a nurse's career (30).

Especially for nurses, older age seems to be negatively related to work ability and job satisfaction; on the other hand, it is positively related to better recovery and less fatigue $(30,32-35)$. Furthermore, older age is related to more prolonged sick leave, whereas younger age is related to more frequent sick leave (36). In their review, Blok and De Looze (37) concluded that it is unclear whether older employees have more problems with tolerance to shift work compared with younger employees. These findings highlight the complexities in understanding the relationship between shift work and aging (38). 
In the above-mentioned studies, age was operationalized as calendar age, but calendar age may be an inadequate operationalization of age in the work context. Because age refers to many changes in biological, psychosocial and social functioning over time, it has been suggested that more than one conceptualization is needed to operationalize age $(39,40)$. Five operationalizations of age have previously been applied: 1) chronological age, 2) organizational age, 3) life-span age, 4) psycho-social age, and 5) functional age. Chronological age refers to the calendar age. Organizational age refers to the aging of individuals in jobs and organizations and is mostly operationalized as working history. Life-span age emphasizes the influence of family life and economic constraints on behavioural changes in the life cycle and the consequences for their work approach and can best be measured by the private situation. Psycho-social age refers to the environment and employees' experiences of age (39). Finally, functional age refers to the neurocognitive and physical decline with ageing, for which a healthy lifestyle is used as a proxy $(6,38-40)$.

Thus, overall, work schedules are related to aspects of sustainable employability. Age differs between the various types of work schedule and it is indicated that age is associated with sustainable employability. Chronological age seems to be a proxy for other age-related processes which might influence sustainable employability (41). However, because few studies have examined the relationship between types of work schedule, age and sustainable employability among nurses $(37,42)$, more research on employability and age is needed (43).

\section{Aim}

The main aim of this study is to describe expected differences between the five types of work schedule of the new typology (29) for the following aspects of sustainable employability: health, fatigue, work ability, emotional exhaustion, work engagement, work-home interference, job satisfaction, and sickness absence. Furthermore, to establish to what extent various operationalizations of age explain these differences.

The research questions are as follows:

1. What are the differences in sustainable employability (e.g. health, fatigue, work ability, emotional exhaustion, work engagement, work-home interference, job satisfaction, and sickness absence) between nurses working in the five types of work schedule described in the new typology of work schedules?

2. When differences in sustainable employability are found, how are they related to the types of work schedule, or to age (operationalized as chronological age, organizational age, life-span age and functional age), or to a combination of work schedule and age?

\section{METHOD}

\section{Design and procedure}

A cross-sectional study was performed in which a questionnaire was sent to the home address of all nursing staff of three large residential care organizations in the Netherlands. Nurses were asked to return the questionnaires within two weeks. Reminder letters were sent to non-responders at two and three weeks after the initial distribution of the questionnaires.

\section{Sample}

The study involved nurses working shifts or irregular working hours in residential elder care. The three homes that participated were asked to participate because the work schedules of the nurses reflected the variety of nursing work schedules most common in the Netherlands. Nurses were included only if they reported their type of work schedule. Of all 1009 nurses invited to participate, 974 met the inclusion criteria. Of these 974 nurses, 498 returned the questionnaire (response rate of $51 \%)$. Table 1 presents the characteristics of the participating nurses.

\section{Data collection}

In October 2009, via the questionnaire, information was gathered about the type of work schedule, age and health, work ability, work engagement, work-home interference, and job satisfaction Furthermore, registered sickness absenteeism data were used. Educational level and hours worked on a contractual basis were not related to the outcomes and were left out of the analyses.

\section{Type of work schedule}

The work schedule was measured by asking the respondents when their working days began and ended, and which shifts they worked (morning, afternoon and night shifts). They were also asked whether they worked other shifts besides the standard morning, late and night shifts. Initially, 24 different shifts were mentioned; after a first evaluation, these were reduced to eight different shifts. Finally, five types of shifts were distinguished and coded as follows (29):

Type 1: fixed early shift;

Type 2: rotating two-shift pattern (early and afternoon shifts);

Type 3: rotating three-shift pattern (early, afternoon and night shifts); Type 4: fixed and rotating two-shift pattern including night shift; Type 5: fixed normal day or afternoon shifts.

In this study, age was operationalized in four ways (39) as follows:

1. Chronological age was operationalized as calendar age in years (range 18-65 years). 


\section{Organizational age was operationalized as the working history as a nurse.}

3. Life-span age can best be measured by life stage or family status. According to Peeters et al. (44), besides the structural home characteristics, it is important to include the perception of these characteristics (44). Therefore, life-span age was measured with (three) structural home characteristics and (four) psychosocial home characteristics, according to Karasek's Job Demand Control Support model. The structural home characteristics are: 1 ) the number of children aged $\leq 12$ years, 2) the amount of child care, and 3) the amount of informal care per week. The psychosocial home characteristics are measured by: 1) emotional home demands, 2) quantitative home demands, 3) home autonomy, and 4) social support at home. Emotional home demands contain four items and quantitative home demands five items; both are scored on a 4-point scale ranging from 0 'never' to 3 'always'. Example items are: "How often do emotional issues arise at home?" and "Do you find that you are busy at home?" The internal consistency (Cronbach's alpha) is 0.81 and 0.78 , respectively (44). Home autonomy contains four items scored on a 5 -point response scale, ranging from 0 'never' to 4 'always'. An example item is: "I have control over how I use my free time' (45). The internal consistency (Cronbach's alpha) is 0.74 . Social support at home contains eight items (measuring social support from one's spouse, relatives and friends) scored on a 5-point response scale ranging from 0 'never' to 4 'always'. An example item is: "To what extent is/are your [spouse/relatives/friends] willing to listen to your problems?" The internal consistency (Cronbach's alpha) is 0.88 (46).

4. Functional age: to measure this, a healthy lifestyle was used as a proxy (40). Healthy lifestyle was measured with a compound scale that provides information on five behaviours: physical activity, smoking, alcohol use, consumption of fruit or vegetables and quality of sleep. It provides an 'optimal lifestyle index' (47). Each behaviour is classified as a binary variable. Meeting the norm for each behaviour is scored ' 1 ' and not meeting it is scored ' 0 '. Scores are summed to form a lifestyle index ranging from 0 'low adherence' to 5 'high adherence' (reflecting the healthiest lifestyle). In accordance with the Dutch Standard for Healthy Exercise, physical activity was assessed as the number of days in a usual week that nurses are engaged in activities that are vigorous or of moderate physical intensity (48). The criterion for a score of 1 was met if nurses engaged in $\geq 150$ $\mathrm{min} /$ week of moderate physical activity or engaged in $\geq 60 \mathrm{~min} /$ week of vigorous activity. Smoking was assessed with the question "Do you smoke?". 'No' scored 1. Alcohol consumption was assessed using the average number of alcohol drinks per week. Not more than 7 units of alcohol per week for women and not more than 14 units for men was scored 1 (Health Council Netherlands, 2006). Fruit and vegetable consumption was assessed by asking on how many days $\geq 200 \mathrm{~g}$ of fruits and vegetables were consumed in a typical week. A score of 1 required seven days per week for both fruit and vegetables. Quality of sleep was assessed with the sleep quality scale in the Dutch Quality of Work Questionnaire [Vragenlijst Beleving en Beoordeling van de Arbeid (VBBA)], which contains 14 subjective items. An example item is "When I wake up in the night, it is hard for me to fall asleep again". Each item was scored as either 'yes' (1) or 'no' (0); the scores were then averaged with a higher score indicating more sleep complaints. The internal consistency (Cronbach's alpha) is 0.88 . The median split method ( $M e d=0.22$ ) was used to dichotomize this scale into high quality of sleep (scored 1) and low quality of sleep (scored 0 ).

Due to lack of research on psychosocial age (40) this item was left out of the present study.

Sustainable employability

Health, work ability, work engagement, work-home interference, job satisfaction and sick leave are important indicators (or proxies) which are used to measure sustainable employability $(6,10$ $20,43,49,50)$. Therefore the following aspects of sustainable employability were used:

General health was measured using a single item asking "In general, how satisfied are you with your health?" which was scored on a 10-point scale from 1 'very dissatisfied' to 10 'very satisfied'. General fatigue was measured with the Multidimensional Fatigue Inventory (MFI) (51). This scale has four items scored on a 5-point scale ranging from 'yes, that is true' to 'no, that is not true'; a higher score indicates more general fatigue. An example item is 'I feel very tired'. The internal consistency (Cronbach's alpha) is 0.84 .

Emotional exhaustion was measured using the Dutch version of the Maslach Burnout Inventory (52). This instrument is particularly suitable for use in human services professions like nursing. Moreover, emotional exhaustion is the most characteristic burnout dimension. The scale has five items scored on a 7-point scale ranging from 0 'never' to 6 'always'. An example item is: "I feel burned out about my work". The internal consistency (Cronbach's alpha) is 0.84-0.90.

Work ability was measured using a single item of the Work Ability Index (WAI) asking 'The subjective estimation of the current work ability compared with the lifetime best', with a possible score of 0 'Completely unable to work' to 10 'Work ability at its best'. This item has shown a strong correlation with the total WAI and is a good alternative to the WAI for assessing the status and progress of work ability (53).

Work engagement was used to measure the positive, work-related state of fulfilment and was measured with the short version of the Utrecht work engagement scale (UWES-9) (54). It contains nine items and is a reliable and valid self-report questionnaire (55). Participants respond on a 7-point Likert scale, ranging from 0 'never' to 6 'always and daily'. Higher scores indicate greater work engagement. An example item is: "At my work I feel bursting with energy". The internal consistency (Cronbach's alpha) is 0.93 .

Work-home interference was measured using a scale from the Survey Work-Home Interference Nijmegen designed to measure types of work-home interference on aspects of strain and time (56) It has eight items scored on a 4-point scale, ranging from 0 'seldom or never' to 3 'very often'. A higher score reflects more interference. An example item is "How often does it happen that your 
work schedule makes it difficult for you to fulfil your domestic obligations?". The internal consistency (Cronbach's alpha) of the scale is 0.84 .

Job satisfaction was measured using a single item asking "How satisfied are you with your job in general?" scored on a 10-point scale ranging from 1 'very dissatisfied' to 10 'very satisfied'.

Sickness absence was assessed using the organizations' absenteeism reports. Sickness absence due to pregnancy was not categorized as sickness absence. Sickness absence was registered by the organization according to the number and duration of absence episodes for each person and were linked to the data from the questionnaire by a code. To measure the sick days duration, the total number of sick days that each employee had taken between 1 October 2008 and 1 October 2009 was counted, irrespective of the actual working hours. Because the distribution of the number of sick days was skewed, this variable was recoded into 'no absence', 'short' ( $<8$ days) and 'prolonged' ( $>7$ days) sickness absence in accordance with the Dutch Bureau of Statistics (57). The frequency of sickness absence episodes was assessed as the number of absences between 1 October 2008 to 1 October 2009. This variable showed a normal distribution and was treated as a continuous variable.

\section{Ethical considerations}

The study was not submitted to an ethical committee because, according to Dutch law (Wet Medisch-Wetenschappelijk Onderzoek met Mensen/Medical Research Involving Human Subjects Act), surveys only have to be submitted to an ethical committee in a limited number of situations, and does not apply to the present study. This study was approved by the management board of the three nursing homes involved. The participants were informed by an individual letter and an institutional newsletter, they were free to refuse to participate and were encouraged to ask questions or express concerns about the study at any time. Return of a completed questionnaire was taken as implied consent. Data were stored anonymously and treated confidentially. Participants were not subjected to invasive treatments, and the participants' privacy was sufficiently guaranteed.

\section{Data analysis}

Data were analysed using IBM SPSS version 20.0. Cronbach's alpha reliability was used to measure the internal consistency of the scales. Descriptive statistics were computed for the variables.

To answer the research questions, one-way ANOVAs were used to test for significant differences in the study variables between the five types of work schedule. Because no assumptions about the differences were present, ANOVAs were used instead of linear regression analysis with dummy coding for the types of schedule. When ANOVAs were used, post-hoc analyses (Tukey) were performed. The general linear model ANCOVAs were used to repeat the analysis for each aspect of sustainable employability in different models when introducing different operationalizations of age as a covariate. Types of work schedule and the different operationalizations of ages were entered into the analysis at the same time. To detect the partial effect size of the type of work schedule and age on health, work ability, work engagement, work-home interference and sickness absence, partial etas squared $\left(\eta_{p}{ }^{2}\right)$ were computed. Cohen's effect sizes were used $(58)\left(\eta_{p}{ }^{2}=0.01\right.$ a small effect, $\eta_{p}{ }^{2}=0.06$ medium effect and $\eta_{p}{ }^{2}=0.14$ a large effect). A log10 transformation was used to approach a normal distribution, because sickness absence duration had considerable skewness (3.28). After this transformation, the indices for skewness and kurtosis were within the ranges ( 0.94 and 0.152 , respectively) (59). $B$-values were computed to indicate the direction of the relationship of age with the indicator variables, except for type of work schedule as it is not possible to compute $b$-values for a nominal variable.

\section{Validity and reliability}

Validated scales were used. For factors, combined in scales, Cronbach's alpha reliability was higher than 0.70 , which is considered acceptable (60). Assuming small to medium effect sizes with five groups, statistical power should be sufficient in the present study $(58,61)$

\section{RESULTS}

The characteristics of the nurses are presented in Table 1.

Table 1: Description of nurses and operationalizations of 'age' $(n=498)$

\begin{tabular}{|c|c|c|c|}
\hline \multirow{2}{*}{\multicolumn{2}{|c|}{ Women }} & \multicolumn{2}{|r|}{ Values } \\
\hline & & 482 & $(96.8 \%)$ \\
\hline Average number of hours worked per week & Mean (SD) & 22.0 & $(S D=8.79)$ \\
\hline Average number of overtime hours worked per week $(n=469)$ : & Mean (SD) & 3.0 & $(S D=4.66)$ \\
\hline Full-time contract & & 28 & $(5.7 \%)$ \\
\hline Job status (permanent) & & 442 & $(89.1 \%)$ \\
\hline Worked nights $(n=462):$ & & 190 & $(41.1 \%)$ \\
\hline Average no. of nights worked per month of those working nights & Mean (SD) & 3.8 & $(S D=3.0)$ \\
\hline Working weekends & & 472 & $(95 \%)$ \\
\hline \multicolumn{4}{|l|}{ Operationalizations of age } \\
\hline \multicolumn{4}{|l|}{ Chronological Age } \\
\hline Age in years & Mean (SD) & 42.2 & $(S D=11.95)$ \\
\hline \multicolumn{4}{|l|}{ Organizational age } \\
\hline Average years working in the current job & Mean (SD) & 9.2 & $(S D=8.1)$ \\
\hline \multicolumn{4}{|l|}{ Life-span age } \\
\hline Taking care of child aged $<12$ years & & 163 & $(32.9 \%)$ \\
\hline No. of days of day care per week & Mean (SD) & 0.38 & $(S D=1.0)$ \\
\hline Hours spent on informal care per week & Mean (SD) & 1.47 & $(S D=2.95)$ \\
\hline Emotional home demands & Mean (SD) & 0.63 & $(S D=0.49)$ \\
\hline Quantitative home demands & Mean (SD) & 1.29 & $(S D=0.53)$ \\
\hline Social support at home & Mean (SD) & 2.63 & $(S D=0.77)$ \\
\hline Home autonomy & Mean (SD) & 2.86 & $(S D=0.68)$ \\
\hline \multicolumn{4}{|l|}{ Functional age } \\
\hline Healthy lifestyle & Mean (SD) & 2.58 & $(S D=0.99)$ \\
\hline
\end{tabular}

*The educational level was distinguished by five levels: care helper level 1, care helper level 2, care worker level 3, nurse level 4 implying secondary vocational education, and nurse level 5 implying higher vocational education. 
The final sample (498) comprised mainly women; the mean age was 42.2 years and $5.7 \%$ had full-time contracts (i.e. 36 contractual work hours/week). The most common educational level was level 3. About half of the nurses had children living at home. The majority had a permanent job status and were living together with an employed partner.

Based on the organizations' reports, the socio-demographics of the non-respondents ( $n=476$; 49\%) showed no significant differences compared with the participants (e.g. for average number of hours/overtime hours per week, income, type of position, and sickness absence duration). However the non-respondents were on average younger than the respondents, i.e. $37.5(S D=11.83)$ years vs. 42.2 years ( $S D=12.04$ years) $(p<0.01)$

Table 2 shows that aspects of sustainable employability differed between the types of work schedule. Regarding the indicators of health, nurses with a type 1 schedule experienced a highe level of general health than nurses with a type 5 schedule. Nurses with type 3 and 4 schedules experienced a higher level of general fatigue than nurses with a type 1 schedule. Nurses with type 2 and 3 schedules were more emotionally exhausted than nurses working in a type 1 schedule. Work engagement differed significantly between the types of work schedule. Nurses with a type 3 schedule were more engaged in their work than nurses working in a type 4 schedule.

Table 2: Aspects of sustainable employability: health, work engagement, work ability, work-home interference, job and sick leave by type of work schedules.

\begin{tabular}{|c|c|c|c|c|c|c|c|c|c|c|}
\hline \multirow[b]{2}{*}{ Indicators } & \multirow[b]{2}{*}{$a$} & \multicolumn{6}{|c|}{ Type of work schedule (ToW) \# } & \multicolumn{2}{|c|}{ ANOVA } & \multirow{2}{*}{$\frac{\eta_{p}^{2}}{\text { ToW }}$} \\
\hline & & 1 & 2 & 3 & 4 & 5 & Total & $F(d f)$ & $\begin{array}{l}\text { Post- } \\
\text { hoc }\end{array}$ & \\
\hline General health & n.a. & $7.89 \Sigma$ & 7.27 & 7.64 & 7.10 & 6.88 & 7.40 & 4.143 & $5<1$ & $0.033^{* 4}$ \\
\hline (score 1-10) & & (1.48) & (1.52) & (1.38) & (1.69) & (1.45) & (1.50) & $(4,487)$ & & \\
\hline General fatigue & 0.89 & 2.26 & 2.63 & 2.81 & 2.87 & 2.64 & 2.68 & 2.785 & $1<3,4$ & $0.022^{*}-3 x-1$ \\
\hline (score 1-5) & & (1.14) & $(1.09)$ & $(1.01)$ & (1.19) & $(1.06)$ & $(1.08)$ & $(4,488)$ & & \\
\hline Work Ability & n.a. & 7.60 & 7.16 & 7.46 & 7.12 & 7.03 & 7.29 & 1.832 & & 0.016 \\
\hline (score 1-10) & & (1.35) & (1.49) & (1.43) & (1.36) & (1.33) & (1.44) & $(4,460)$ & & \\
\hline Emotional exhaustion & 0.91 & 1.47 & 2.07 & 2.16 & 1.78 & 1.91 & 2.01 & 3.049 & $1<2,3$ & $0.024^{*}$ \\
\hline (score 0-6) & & (1.14) & (1.35) & $(1.35)$ & $(1.05)$ & (1.18) & (1.31) & $(4,489)$ & & \\
\hline Work Engagement & 0.92 & 4.64 & 4.45 & 4.70 & 4.18 & 4.44 & 4.53 & 3.244 & $4<3$ & $0.026^{*}$ \\
\hline (score 0-6) & & $(.92)$ & (.93) & (.88) & $(1.09)$ & $(1.25)$ & (.96) & $(4,485)$ & & \\
\hline Work-home & 0.87 & 0.59 & 0.77 & 0.86 & 0.60 & 0.59 & 0.76 & 6.880 & 1,4 & $0.054^{*}$ \\
\hline interference (score 0-3) & & $(0.39)$ & $(0.43)$ & $(0.43)$ & $(0.42)$ & $(0.41)$ & $(0.43)$ & $(4,482)$ & $5<3$ & \\
\hline Job satisfaction & n.a. & 7.64 & 7.19 & 7.23 & 7.44 & 7.12 & 7.26 & 1.340 & & 0.011 \\
\hline (score 1-10) & & $(1.48)$ & (1.29) & (1.41) & $(1.60)$ & (1.15) & (1.37) & $(4,487)$ & & \\
\hline Sickness absence & n.a. & 0.86 & 1.57 & 1.78 & 1.15 & 1.56 & 1.54 & 3.338 & $1<3$ & $0.029^{*}$ \\
\hline episodes & & (1.32) & (1.61) & (1.77) & (1.33) & $(1.48)$ & $(1.63)$ & $(4,450)$ & & \\
\hline $\begin{array}{l}\text { (score 0-9) } \\
\text { Sickness absence } \\
\text { duration } \\
\text { (score 0-3a })\end{array}$ & n.a. & $\begin{array}{l}0.56 \\
(0.85)\end{array}$ & $\begin{array}{l}0.99 ; \\
(0.95)\end{array}$ & $\begin{array}{l}0.81 \\
(0.71)\end{array}$ & $\begin{array}{l}0.67 ; \\
(0.76)\end{array}$ & $\begin{array}{l}0.85 ; \\
(0.84)\end{array}$ & $\begin{array}{l}0.85 ; \\
(0.85)\end{array}$ & $\begin{array}{l}3.337 \\
(4,476)\end{array}$ & $1<2$ & $0.027^{*}$ \\
\hline
\end{tabular}

$p<0.05 ; " * p<0.01 ;{ }^{* * *} p<0.001 ; \eta_{p}{ }^{2}=0.01$ a small effect, $\eta_{p}{ }^{2}=0.06$ medium effect, $\eta_{p}{ }^{2}=0.14$ a large effect.

\#: 1 = fixed early shifts ; 2 = rotating 2-shift (early and afternoon shifts) ; $3=$ rotating 3 -shift (early, afternoon and night shifts); $4=$ fixed nightshift or 2 -shifts including night shift and $5=$ fixed shifts normal day or afternoon shifts. $\mathrm{A}=$ after $\log 10$ transformation.
Regarding work-home interference, nurses with a type 3 schedule experienced more work-home interference than nurses with type 1, 4 and 5 schedules.

Regarding sickness absences, nurses' episodes of sickness absence differed significantly between the types of work schedule. Nurses with a type 3 schedule more frequently had absent periods than nurses with a type 1 schedule. Also, the duration of sickness absence showed a significant difference between the types of work schedule. Nurses with a type 2 schedule had a longer duration of sickness absence than nurses with a type 1 schedule. Overall, nurses working in a type 1 shift appeared to fare the best on the aspects of sustainable employability.

Table 3 shows the results of the analyses when different operationalizations of age were added. Only the significant effect sizes are shown (partial eta squared and $b$-values). 


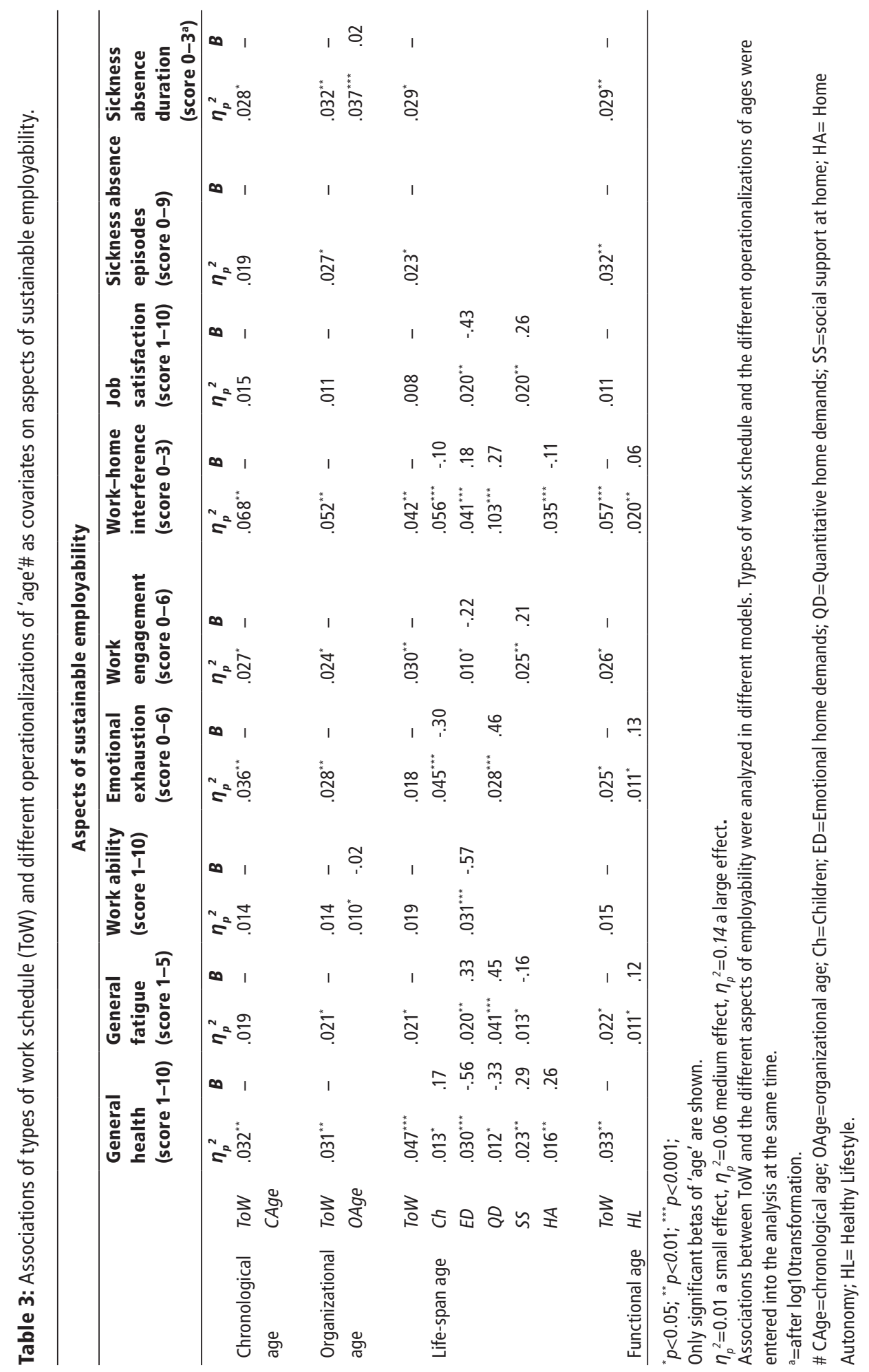

When chronological age was added to the analysis, differences were found between the types of work schedule for the following aspects of sustainable employability: general health, emotional exhaustion, work engagement, work-home interference and sickness absence duration. Chronological age explained a small part of the variance in general fatigue, work ability, emotional exhaustion, work-home interference, and episodes of sickness absence.

When organizational age was added to the analysis, differences were found between the types of work schedule for the following aspects of sustainable employability: general health, general fatigue, emotional exhaustion, work engagement, work-home interference, sickness absence episodes and duration. Organizational age explained only a small part of the variance in work ability and a modest part of the variance in sickness absence duration.

When life-span age was added to the analysis, differences were found between the types of work schedule for the following aspects of sustainable employability: general health, general fatigue, work engagement, work-home interference, sickness absence episodes and duration. Lifespan age explained a medium to large part of the variance in health, general fatigue, work ability, emotional exhaustion, work engagement, work-home interference and job satisfaction, but not episodes of sickness absence and duration.

When functional age was added to the analysis, there was no change in the differences in aspects of sustainable employability between the types of work schedule. Functional age explained a small part of the variance in general fatigue, emotional exhaustion and work-home interference.

\section{DISCUSSION}

To our knowledge this is the first study to investigate differences between nurses who work in various types of work schedule regarding sustainable employability whilst also taking into account different operationalizations of nurses' age.

The differences found between the types of work schedule for aspects of sustainable employability were small to large and, for the greater part, related to the type of work schedule rather than age. Differences between the types of work schedule were found for general health, general fatigue, emotional exhaustion, work engagement, work-home interference, and sickness absence episodes and duration.

Especially nurses with a type 1 schedule (fixed early shift) showed the greatest contrast with nurses with a type 3 schedule (with a rotating three shift pattern). The latter can be considered as being 'worse off' concerning sustainable employability and are, in agreement with others, characterized by more negative features $(3,18,30)$. Most likely, nurses move to less demanding schedules because of e.g. health problems, changing family responsibilities, or age, i.e. the so-called secondary selection $(30,62-65)$. From this viewpoint, nurses with a type 1 schedule are noteworthy. They can be considered as more advantaged with regard to sustainable employability, with higher 
levels of health, lower work-home interference, less general fatigue, less emotional exhaustion, more work engagement and fewer episodes of sickness absence and shorter sickness absence duration. It is reported that transitions in work hours can indeed affect health positively $(66,67)$.

Although, in general, the type of work schedule is more important for sustainable employability than operationalizations of age, the present study shows the importance of including life-span age rather than chronological, organizational or functional age. No differences were found between the types of work schedule and work ability and job satisfaction. Work ability, emotional exhaustion and job satisfaction were only related to the life-span age and not to the types of work schedule. Chronological age and organizational age hardly explained differences in the aspects of nurses' sustainable employability between the types of work schedule. This is in line with Merkus et al. (25) who found that seniority was a poor proxy of shift work experience. Nurses' sickness absence duration, as well as episodes, differed between the types of work schedule and were only slightly related to chronological age and organizational age. These findings were in the expected direction $(36,68)$. Older chronological age was associated with less sickness absence episodes, whereas higher age of professionalism was associated with longer sickness absence duration. which is also in line with Thomson, Griffiths, and Davison (69). Differences between the types of work schedule regarding nurses' sickness absence and episodes were related to the types of work schedule and not to the life-span age. In line with other reports (70), life-span age is probably more a proxy of health than of sickness absence.

In our (mainly) female nursing population, life-span age, expressed by structural and psychosocial home characteristics, seems almost as important as the types of work schedule for sustainable employability, in particular for work ability, emotional exhaustion and job satisfaction. Decisions and choices around scheduling are influenced by family considerations and most often not by their own health and well-being, especially for workers with more extensive family responsibilities (71). Women are still more responsible for household and childcare than men (64) and relationships between life-span age and sustainable employability could be aggravated by gender differences and causes outside the workplace $(72,73)$. It could therefore be, that life-span age is more meaningful for women with respect to sustainable employability than for man (40)

Remarkably, having more children aged $\leq 12$ years is related to better general health, less emotional exhaustion and less work-home interference. This might be explained by a protective effect: i.e. the combination of work and children may have enriched the working mother's health (74). An alternative explanation could be that having children invites employees to work fewer work hours $(75,76)$. Female nurses might prefer non-standard working hours as a conscious choice to arrange childcare in combination with the partners' job $(64,77)$. Indeed, additional analysis showed a negative correlation $(r=-0.39 ; p=0.000)$ between the number of children aged $\leq 12$ years and the number of hours worked. However, because the number of children and number of hours worked per week did not differ between the types of work schedule (29), this explanation seems complex and needs more research to elucidate the cause and effect. Emotional and quantitative home demands were associated with lower sustainable employability, whereas home autonomy and more social support at home were associated with higher sustainable employability. The protective role of social support at home and higher home autonomy supports the value of the home as a resource $(30,70,78)$.

Although less important than the types of work schedule, functional age (expressed by adherence to a healthy lifestyle) was associated with higher general fatigue, higher emotional exhaustion and more work-home interference. It is possible that combining a healthy lifestyle, shift work and care, leaves no time for recovery after work, particularly when there is insufficient support at home or control over their work schedules $(16,79,80)$.

\section{Strengths and limitations}

A positive point related to representativeness is that the characteristics of our participating nurses (besides the prevalence of types of work schedule) were similar to those of nurses working in comparable institutes in the Netherlands regarding age, sex, average work week, employment status and number of years in the current job (23). This similarity reduces the risk of unrepresentativeness. However, the prevalence of part-time work of other European countries, varies with the Netherlands as a leading country in part-time working (81). Therefore, extrapolation of our findings to European countries other than the Netherlands has to be made with care.

Due to the use of company registered sickness absence data, rather than of self-reported data, we tried to increase the validity and prevent our results from recall bias; this can be a problem when using self-reported sickness absence data concerning recall periods of longer than two months (82).

Although our non-respondents were slightly younger, it is difficult to evaluate whether this affected the associations found in the present study, because we have no information on the nonrespondents' work schedules. Our findings might indicate a healthy worker effect (83). Since nurses in the type 1 shift are the eldest, but also seem to be the healthiest, nurses who 'could not stand the pressure' may have left the profession or moved from a demanding type of work schedule to a less demanding one (66). Due to the cross-sectional design of this study, we cannot rule out this effect. However, it could be assumed that in both ways it could have led to an underestimation of the associations between age and sustainable employability.

The average work week and overtime hours are representative for nurses in the Netherlands (24), and it seems unlikely that nurses execute a second job. However, it could be worthwhile to find out if the demands of a second job or informal care tasks deplete resources and decrease recovery and alter the observed associations between types of work schedule and sustainable employability.

Nurses with a permanent contract were slightly over-represented compared to the European countries. Contract type seems to moderate the relationship between job characteristics and sustainable employability and seems not directly related to sustainable employability $(84,85)$. 
Although it was not the purpose of our study to test moderators of sustainable employability, this could have influenced the sustainable employability in our sample. Finally, we focused on the types of work schedules and various operationalizations of age in relation to sustainable employability. Although work demands and social support do not seem to differ when shift workers are compared to day workers $(86,87)$, we cannot explain differences in sustainable employability associated with other occupational factors such as higher levels of physical demands, emotional demands and management quality $(73,88)$ or that these occupational factors moderate the associations between the types of work schedule and sustainable employability (89).

\section{CONCLUSIONS}

This research offers insight into the differences between types of work schedule with regard to aspects of nurses' sustainable employability, and the complex relation with age. Nurses' sustainable employability appeared to be mainly related to differences between the types of work schedule rather than age. The life-span age also appeared to be important with respect to sustainable employability. Nurses working in different types of work schedule differ in age; however, chronological age and organizational age are hardly related to the differences in health, emotional exhaustion, work engagement, work-home interference and sickness absence duration found between nurses working in the different work schedules.

\section{Practical and scientific implications}

A system in which nurses with different types of work schedule are monitored in combination with their life-span perspective is important with respect to sustainable employability. Our new evidence-based typology of work schedules seems suitable and might help organizations to monitor aspects of sustainable employability of nurses working in different types of work schedule. Nurses with a type 3 schedule seem to require the most attention, a type 1 schedule could be offered as a 'temporary solution' for nurses with problems related to sustainable employability. Organizations should also be aware of the importance of the nurses' perception of home resources and demands, and should implement interventions to emphasize the life-span perspective of nurses with shift work.

In research, the types of work schedule should be taken into account.

Longitudinal research, preferably with a longer period (e.g. 10 years), is needed to examine the effect of types of work schedule and life-span age on sustainable employability. Furthermore, such studies should demonstrate which operationalization of age plays a role as an underlying mechanism for the career stage or choice of work schedule $(38,40)$. This is not only interesting for residential elder care, but also for other professions which have varying work schedules.

\section{Conflict Of Interest}

The authors declare that they have no conflict of interest.

\section{REFERENCES}

1. Kingma M. Nurses on the Move: A Global Overview. Health Services Research. 2007;42(3p2):1281-98.

2. Sherman RO, Chiang-Hanisko L, Koszalinski R. The ageing nursing workforce: a global challenge. Journa of Nursing Management. [Editorial]. 2013 Oct;21(7):899-902.

3. Hasselhorn H-M, Oginska H, Tackenberg P, Pokorski J, Estryn-Behar M, Camerino D, et al. Nurses Early Exit Study - (NEXT) - scientific results. Wuppertal: University of Wuppertal2005.

4. Phillips JA, Miltner R. Work hazards for an aging nursing workforce. Journal of Nursing Management. 2014 Mar 7.

5. Van der Klink JJL, Burdorf A, Schaufeli WB, Van der Wilt GJ, Zijlstra FRH, Brouwer S, et al. Duurzaam inzetbaar: werk als waarde. Rapport in opdracht van ZonMw ten behoeve van het programma Participatie en Gezondheid. . Groningen: Rijksuniversiteit Groningen.2010.

6. De Lange AH, van der Heijden BIJM. Duurzame inzetbaarheid en ouder worden op het werk: Bent u of is de werknemer aan zet? In: De Lange AH, Van der Heijden BIJM, editors. Een leven lang inzetbaar? Duurzame inzetbaarheid op het werk: interventies, best practices en integrale benaderingen. Alphen aan de rijn: Vakmedianet; 2013. p. 17-64.

7. Hagglund KM, Helsing C, Sandmark H. Assistant nurses working in care of older people: associations with sustainable work ability. Scandinavian Journal of Caring Sciences. [Research Support, Non-U.S. Gov't]. 2011 Jun;25(2):325-32.

8. Friis K, Ekholm O, Hundrup YA. The relationship between lifestyle, working environment, socio-demographic factors and expulsion from the labour market due to disability pension among nurses. Scandinavian Journal of Caring Sciences. 2008;22(2):241-8.

9. Carter MR, Tourangeau AE. Staying in nursing: what factors determine whether nurses intend to remain employed? Journal of Advanced Nursing. [Research Support, Non-U.S. Gov't]. 2012 Jul;68(7):1589-600.

10. Heinen MM, van Achterberg $T$, Schwendimann $R$, Zander $B$, Matthews $A$, Kózka $M$, et al. Nurses' intention to leave their profession: A cross sectional observational study in 10 European countries. Int J Nurs Stud. 2012 Oct.

11. Tucker P, Folkard S. Working time, health, and safety : A research synthesis paper. Geneva: International Labour Office2012.

12. Costa G. The impact of shift and night work on health. Applied Ergonomics. 1996 Feb;27(1):9-16.

13. Costa G. Shift work and occupational medicine: an overview. Occup Med (Lond). 2003 March 1, 2003;53(2):83-8.

14. Harrington JM. Health effects of shift work and extended hours of work. Occupational and Environmental Medicine. 2001 January 1, 2001;58(1):68-72.

15. Knutsson A. Health disorders of shift workers. Occup Med (Lond). 2003 March 1, 2003;53(2):103-8.

16. Härmä M. Workhours in relation to work stress, recovery and health. Scandinavian Journal of Work, Environment \& Health. 2006 Dec;32(6):502-14.

17. Smith $M$, Eastman C. Shift work: health, performance and safety problems, traditional countermeasures, and innovative management strategies to reduce circadian misalignment. Nature and Science of Sleep 2012;4:111-32. 
18. Muecke S. Effects of rotating night shifts: literature review. Journal of Advanced Nursing. 2005 May; $50(4): 433-9$.

19. Estryn-Behar M, van der Heijden BIJM, Fry C, Hasselhorn H-M. Longitudinal analysis of personal and work-related factors associated with turnover among nurses. Nursing Research. 2010;59(3):166-77.

20. Hayes LJ, O'Brien-Pallas L, Duffield C, Shamian J, Buchan J, Hughes F, et al. Nurse turnover: a literature review - an update. International Journal of Nursing Studies. 2012 Jul;49(7):887-905.

21. McVicar A. Workplace stress in nursing: a literature review. Journal of Advanced Nursing. 2003 Dec;44(6):633-42.

22. Lee S, McCann D, Messenger JC. Working Time Around the World: Trends in working hours, laws, and policies in a global comparative perspective. London and Geneva: Routledge and IL02007.

23. AZWinfo. Arbeid in Zorg en Welzijn 2010 [Work in Care and Social Welfare]. Zoetermeer: Panteia2011.

24. Haanstra-Veldhuis V, De Zwart BCH. Flexibilisering en werkbeleving in de vvt-sector: onderzoek onder medewerkers in de verzorging \& verpleging en thuiszorg. 2013.

25. Merkus SL, van Drongelen A, Holte KA, Labriola $M$, Lund $T$, van Mechelen $W$, et al. The association between shift work and sick leave: a systematic review. Occupational and Environmental Medicine. [Research Support, Non-U.S. Gov't Review]. 2012 Oct;69(10):701-12.

26. Barker LM, Nussbaum MA. Fatigue, performance and the work environment: a survey of registered nurses. Journal of Advanced Nursing. 2011 Jun;67(6):1370-82.

27. Staines GL, Pleck JH. Nonstandard work schedules and family life. Journal of Applied Psychology. 1984;69(3):515-23

28. Åkerstedt T. Shift work and disturbed sleep/wakefulness. Occupational Medicine. 2003 March 1 , 2003;53(2):89-94.

29. Peters V, Engels J, De Rijk AE, Nijhuis FJN, editors. Work time arrangements and work-home interference among nurses. EAWOP, 15th Conference of the European Association of Work and Organizational Psychology; 2011 May 28; MECC Maastricht.

30. Winwood PC, Winefield AH, Lushington K. Work-related fatigue and recovery: the contribution of age, domestic responsibilities and shiftwork. Journal of Advanced Nursing. 2006;56(4):438-49.

31. Sveinsdottir $H$. Self-assessed quality of sleep, occupational health, working environment, illness experience and job satisfaction of female nurses working different combination of shifts. Scandinavian journal of caring sciences. 2006 Jun;20(2):229-37.

32. Camerino D, Conway PM, van der Heijden BIJM, Estryn-Behar M, Consonni D, Gould D, et al. Low-perceived work ability, ageing and intention to leave nursing: a comparison among 10 European countries. Journal of Advanced Nursing. 2006 Dec;56(5):542-52.

33. Flinkman M, Laine M, Leino-Kilpi H, Hasselhorn HM, Salanterä S. Explaining young registered Finnish nurses' intention to leave the profession: A questionnaire survey. International Journal of Nursing Studies. 2008;45(5):727-39

34. Saksvik IB, Bjorvatn B, Hetland $H$, Sandal GM, Pallesen $S$. Individual differences in tolerance to shift work--a systematic review. Sleep medicine reviews. [Review]. 2010 Aug;15(4):221-35.

35. Costa G, Sartori S. Ageing, working hours and work ability. Ergonomics. 2007 Nov;50(11):1914-30.

36. Beemsterboer W, Stewart R, Groothoff J, Nijhuis F. A literature review on sick leave determinants (19842004). Int J Occup Med Environ Health. 2009;22(2):169-79.

37. Blok MM, de Looze MP. What is the evidence for less shift work tolerance in older workers? Ergonomics.
38. Costa G, Di Milia L. Aging and shift work: a complex problem to face. Chronobiology International. 2008 Apr;25(2):165-81.

39. De Lange AH, Taris TW, Jansen P, Smulders P, Houtman I, Kompier M, editors. Age as factor in the relation between work and mental health: results from the longitudinal TAS survey. Castelo de Maia: ISMAl; 2006.

40. Nauta A, De Lange AH, Görtz S. Lang zullen ze leven, werken en leren. Een schema voor het begrijpen en beïnvloeden van inzetbaarheid gedurende de levensloop. Gedrag en Organisatie. 2010;23(2):136 -57.

41. Kooij D, De Lange AH, Jansen PGW, Dikkers JSE. Beyond chronological age. Examining perceived future time and subjective health as age-related mediators in relation to work-related motivations and wellbeing. Work \& Stress. 2013;27(1):88-105.

42. Tucker P, Knowles SR. Review of studies that have used the Standard Shiftwork Index: evidence for the underlying model of shiftwork and health. Applied ergonomics. 2008 Sep;39(5):550-64.

43. Brouwer S, de Lange AH, van der Mei S, Wessels M, Koolhaas W, Bültmann U, et al. Duurzame inzetbaarheid van de oudere werknemer: stand van zaken. Overzicht van determinanten, interventies en meetinstrumenten vanuit verschillende perspectieven. Groningen: Universitair Medisch Centrum Groningen, Rijksuniversiteit Groningen2012.

44. Peeters MCW, Montgomery AJ, Bakker AB, Schaufeli WB. Balancing Work and Home: How Job and Home Demands Are Related to Burnout. International Journal of Stress Management. 2005;12(1):43-61.

45. Demerouti E, Bakker AB, Voydanoff P. Does home life interfere with or facilitate job performance? European Journal of Work and Organizational Psychology. 2010;19(2):128-49.

46. Van Daalen G, Willemsen TM, Sanders K. Reducing work-family conflict through different sources of social support. Journal of Vocational Behavior. 2006;69(3):462-76.

47. Pronk NP, Katz AS, Gallagher J, Austin E, Mullen D, Lowry M, et al. Adherence to optimal lifestyle behaviors is related to emotional health indicators among employees. Popul Health Manag. 2010 Apr;14(2):59-67.

48. Kemper HCG, Ooijendijk WTM, Stiggelbout M. Consensus over de Nederlandse norm voor gezond bewegen. TSG: Tijdschrift voor gezondheidswetenschappen Utrecht: Vereniging voor Volksgezondheid en Wetenschap. 2000;78(3):180-3.

49. Van Holland BJ, de Boer MR, Brouwer S, Soer R, Reneman MF. Sustained employability of workers in a production environment: design of a stepped wedge trial to evaluate effectiveness and cost-benefit of the POSE program. BMC Public Health. 2012;12:1003.

50. Van de Ven HA, Klein Hesselink J, Bultmann U, de Boer MR, de Looze MP, van der Klink JJ, et al. Individual and work-related predictors of work outcomes related to sustainable employment among male shift and day workers. Scandinavian Journal of Work, Environment \& Health. 2013 Oct 16.

51. Smets EMA, Garssen B, Bonke B, De Haes JCJM. The multidimensional Fatigue Inventory (MFI) psychometric qualities of an instrument to assess fatigue. Journal of Psychosomatic Research. 1995;39(3):315-25.

52. Schaufeli WB, Van Dierendonck D. Handleiding van de Utrechtse Burnout Schaal (UBOS). Lisse: Swets Test Services; 2000.

53. Fassi M, Bocquet V, Majery N, Lair ML, Couffignal S, Mairiaux P. Work ability assessment in a worker population: comparison and determinants of Work Ability Index and Work Ability score. BMC Public Health. 2013 Apr 8;13(1):305.

54. Schaufeli WB, Bakker AB. Preliminary Manual UWES; Utrecht Work Engagement Scale. Utrecht University: Occupational Health Psychology Unit; 2004. 
55. Schaufeli WB, Bakker AB, Salanova M. The Measurement of Work Engagement With a Short Questionnaire. Educational and Psychological Measurement. 2006 August 1, 2006;66(4):701-16.

56. Geurts SAE, Taris TW, Kompier MAJ, Dikkers JSE, Van Hooff MLM, Kinnunen UM. Work-home interaction from a work psychological perspective: Development and validation of a new questionnaire, the SWING Work \& Stress, October-December 2005;. 2005;19(4):319-39.

57. CBS. Berekening van verzuim; Nationale verzuimstatistiek [Measuring sickness absence, National Sickness absence statistics, Central Statistical Office]. Voorburg/Heerlen: Centraal Bureau voor de Statistiek (CBS), SRS, SAV.2005.

58. Cohen J. A power primer. Psychological Bulletin. 1992;112(1):155-9.

59. Schaufeli WB, Bakker AB, Van Rhenen W. How changes in job demands and resources predict burnout, work engagement, and sickness absenteeism. Journal of Organizational Behavior. 2009:30(7):893-917.

60. Cortina JM. What is coefficient alpha? An examination of theory and applications. Journal of Applied Psychology. 1993;78(1):98-104.

61. Wilson Van Voorhis CR, Morgan BL. Understanding Power and Rules of Thumb for Determining Sample Sizes. Tutorials in Quantitative Methods for Psychology. 2007;3(2):43-50.

62. Nabe-Nielsen K, Kecklund G, Ingre M, Skotte J, Diderichsen F, Garde AH. The importance of individual preferences when evaluating the associations between working hours and indicators of health and well-being. Applied Ergonomics. 2010;41(6):779-86.

63. Clendon J, Walker L. Nurses aged over 50 years and their experiences of shift work. Journal of Nursing Management. 2013;21(7):903-13

64. Mills M, Taht K. Nonstandard Work Schedules and Partnership Quality: Quantitative and Qualitative Findings. J Marriage Fam. [Article]. 2010 Aug;72(4):860-75

65. Galatsch M, Li J, Derycke H, Muller BH, Hasselhorn HM. Effects of requested, forced and denied shift schedule change on work ability and health of nurses in Europe -Results from the European NEXT-Study. BMC Public Health. 2013 Dec 5;13(1):1137.

66. De Raeve L, Jansen NWH, Kant I. Health effects of transitions in work schedule, workhours and overtime in a prospective cohort study. Scand J Work Environ Health. 2007 Apr;33(2):105-13.

67. Puttonen S, Viitasalo K, Härmä M. Effect of shiftwork on systemic markers of inflammation. Chronobiology International. 2011;28(6):528-35.

68. Donders NC, Bos JT, van der Velden K, van der Gulden JW. Age differences in the associations between sick leave and aspects of health, psychosocial workload and family life: a cross-sectional study. BMJ Open. 2012;2(4).

69. Thomson L, Griffiths A, Davison S. Employee absence, age and tenure: a study of nonlinear eš ects and trivariate models. work \& stress. 2000;14(1):16-34.

70. Ten Brummelhuis LL, ter Hoeven $\mathrm{CL}$, de Jong MDT, Peper B. Exploring the linkage between the home domain and absence from work: Health, motivation, or both? Journal of Organizational Behavior. 2013;34(3):273-90

71. Barthe B, Messing K, Abbas L. Strategies used by women workers to reconcile family responsibilities with atypical work schedules in the service sector. Work. [Research Support, Non-U.S. Gov't]. 2011;40 Suppl 1:S47-58.
72. Leineweber C, Baltzer M, Magnusson Hanson LL, Westerlund H. Work-family conflict and health in Swedish working women and men: a 2-year prospective analysis (the SLOSH study). Eur J Public Health [Research Support, Non-U.S. Gov't]. 2013 Aug;23(4):710-6.

73. Labriola M, Holte KA, Christensen KB, Feveile $H$, Alexanderson K, Lund T. The attribution of work environment in explaining gender differences in long-term sickness absence: results from the prospective DREAM study. Occupational and Environmental Medicine. 2011 Sep;68(9):703-5.

74. Fokkema T. Combining a job and children: contrasting the health of married and divorced women in the Netherlands? Social Science and Medicine 2002;54 (5):741-52.

75. Floderus B, Hagman M, Aronsson G, Marklund S, Wikman A. Work status, work hours and health in women with and without children. Occupational and Environmental Medicine. [Research Support, NonU.S. Gov't]. 2009 Oct:66(10):704-10.

76. Sandmark H, Hagglund $\mathrm{K}$, Nilsson $\mathrm{K}$, Hertting A. Understanding work ability: experiences of female assistant nurses in elderly care. Work. 2009;34(3):373-83.

77. Fagan C, Lyonette C, Smith M, Saldaña-Tejeda A. The influence of working time arrangements on work-life integration or 'balance': A review of the international evidence. Geneva: International Labour Office2012.

78. Bakker AB, Demerouti E. The Job Demands-Resources model: State of the art. Journal of Managerial Psychology. 2007;22(3):309-28.

79. Giver H, Faber A, Stroyer J, Hannerz H, Albertsen K. Do lifestyle factors and general health predic dropout among recently qualified eldercare workers? A two-year follow-up study. Scandinavian Journa of Public Health. [Article]. 2011 May;39(3):280-6.

80. Samaha E, Lal S, Samaha N, Wyndham J. Psychological, lifestyle and coping contributors to chronic fatigue in shift-worker nurses. Journal of Advanced Nursing. 2007;59(3):221-32.

81. Eurofound. Fifth European Working Conditions Survey. Luxembourg: European Foundation for the Improvement of Living and Working Conditions2012.

82. Van Poppel MNM, de Vet HCW, Koes BW, Smid T, Bouter LM. Measuring sick leave: a comparison of self-reported data on sick leave and data from company records. Occupational Medicine. 2002 December 1, 2002;52(8):485-90

83. Conway P, Campanini P, Sartori S, Dotti R, Costa G. Main and interactive effects of shiftwork, age and work stress on health in an Italian sample of healthcare workers. Applied Ergonomics. 2008;39(5):630-9.

84. Kirves K, Kinnunen U, De Cuyper N. Contract type, perceived mobility and optimism as antecedents of perceived employability. Economic and Industrial Democracy. 2013;35(3):435-53.

85. Mauno S, Kinnunen U, Mäkikangas A, Nätti J. Psychological consequences of fixed-term employment and perceived job insecurity among health care staff. European Journal of Work and Organizational Psychology. 2005;14(3):209-37.

86. Bøggild H, Burr H, Tüchsen F, Jeppesen HJ. Work environment of Danish shift and day workers. Scandinavian Journal of Work, Environment \& Health. 2001;27(2):97-105.

87. Parkes KR. Shiftwork, job type, and the work environment as joint predictors of health-related outcomes. Journal of Occupational Health Psychology. 1999;4(3):256-68

88. Magnavita N. Workplace violence and occupational stress in healthcare workers: a chicken-and-egg situation-results of a 6-year follow-up study. J Nurs Scholarsh. 2014 Sep;46(5):366-76.

89. Barton J, Spelten E, Totterdell P, Smith L, Folkard S, Costa G. The Standard Shiftwork Index: a battery of questionnaires for assessing shiftwork-related problems. Work \& Stress. 1995 1995/01/01:9(1):4-30. 


\section{ABSTRACT}

Background: Shiftwork is a major job demand for nurses and has been related to various negative consequences. Research suggests that personal and job resources moderate the impact of work schedules on stress, health and well-being. Objectives: This longitudinal study examined whether the interactions of personal and job resources with work schedule demands predicted work engagement and emotional exhaustion in nursing. Design: This longitudinal study included two waves of data collection with a one year follow-up using self-report questionnaires among 247 nurses working shifts or irregular working hours in residential care for the elderly in the Netherlands.

Methods: Moderated structural equation modelling was conducted to examine the interactions between personal and job resources and work schedule demands. Two work schedule demands were assessed: type of work schedule (demanding vs. less demanding) and average weekly working hours. Two personal resources, active coping and healthy lifestyle, and two job resources, work schedule control and the work schedule fit with nurses' private life, were assessed.

Results: Results showed that the work schedule fit with nurses' private life buffered the relationship between work schedule demands and emotional exhaustion one year later. Furthermore the work schedule fit with nurses' private life increased work engagement one year later when work schedule demands were high. Work schedule control strengthened the positive relationship between work schedule demands and emotional exhaustion one year later. The personal resources, active coping and healthy lifestyle were no moderators in this model.

Conclusion: Nurses suffer less from decreasing work engagement and emotional exhaustion due to work schedule demands when their work schedules fit with their private lives. Work schedule control did not buffer, but strengthened the positive relationship between weekly working hours and emotional exhaustion one year later. Job resources appeared to be more important for nurses' well-being than personal resources. These findings highlight the importance of the fit of a work schedule with nurse's private life, if the work schedule is demanding.

\section{INTRODUCTION}

Shiftwork is a major job demand experienced by many nurses $(1,2)$. It has been related to negative consequences, such as burnout, health problems, decreased motivation, high turnover, decreased work ability, cardiovascular disease, problems with recruitment and retention (2-9)

Research suggests that personal resources, such as coping styles, good sleep quality and physical activity, moderate the impact of work schedules on stress, subjective health, cardiovascular disease and burnout $(7,10,11)$. A cross-sectional study indicated that the fit of the work schedule with nurses' private life moderates the impact of work schedule demands on subjective health (12). Because it may be difficult to change work schedule systems, especially in the short term, another way to limit negative effects on health and well-being is to pinpoint the resources that help workers tolerate demanding schedules $(2,8,13)$. However, research on how personal and job resources moderate the negative effects of work schedule demands is scarce (11)

\section{Work schedule demands in nursing}

This study concentrates on the specific demands of work schedules and its effect on emotional exhaustion and work engagement. Job demands refer to those physical, psychological, social or organizational aspects of work that require sustained physical or psychological (cognitive and emotional) effort or skills. They may turn into stressors when poorly designed jobs or chronic job demands (e.g. work overload, emotional demands) exhaust employees' mental and physical resources, leading to the depletion of energy and, in turn, health problems such as emotional exhaustion. Although there is debate about which work schedules cause more negative consequences, rotating three-shift systems, irregular schedules and nightshifts have been found to have more negative consequences than other work schedules $(5,14-16)$. Another important work schedule demand is the duration of working hours (17). Long working hours are positively related to negative mental and physical health indicators (17-22).

\section{Personal and job resources}

Given that work schedules are an on-going source of stress, personal and job resources can be expected to buffer the negative effects of work schedule demands on health (23-26). According to the Conservation Of Resources (COR) theory, resources are entities that have intrinsic or instrumental value, including objects, conditions, personal resources, and energy resources (27). Job resources are those aspects of work that facilitate the achievement of goals and minimize the effects of job demands. They are functional in accomplishing work goals, and stimulate personal growth and development (28). Personal resources are aspects of the self that are generally linked to resilience. They pertain to individuals' ability to control and influence their environment successfully, especially during challenging circumstances (29). Resources seem to particularly influence work engagement 
when demands are high (28). There is evidence that the above mentioned resources are especially effective in protecting employees from the adverse effects of stressors when they are matched to the specific stressor $(30,31)$. For example Zacher et al. (31) found that employees' satisfaction with eldercare tasks buffered the negative relationship between demands and work performance. However, research on the effect of the interaction between work schedule demands and personal and job resources in relation to work engagement and burnout is scarce and longitudinal research is particularly needed $(11,13,32)$.

\section{Personal resources in nursing}

In view of the specific demands of shift work, this study focuses on active coping and on healthy lifestyle as personal resources. There is considerable variability in the extent to which individuals adapt to shiftwork (33). There are indications that personal resources of a more practical behavioural nature can be expected to moderate the negative consequences of work schedule demands (11, 34-36).

Coping refers to behavioural and cognitive efforts to manage situations that are perceived to tax personal resources. Active coping, conceptualized as behaviour aimed at addressing problems at work by cognitively analysing the situation or by taking action to solve or overcome the problem (37). Active coping is a key personal resource in COR theory as it reflects aspects of the self that are generally linked to resilience (38). Active coping has been found to protect against burnout among nurses (39-42) and has also been found to moderate the negative health effects of job demands on dimensions of burnout $(39,41)$.

Healthy lifestyle is a collective pattern of health-related behaviour $(25,43)$ and is in line with the common sense idea that a healthy life is linked to resilience (44). It can be defined as personal behavioural resource and includes adherence to adequate physical activity, abstinence from smoking, consuming limited or no alcohol, and healthy eating (45). In this study, quality of sleep was added as an indicator of shiftworkers' capacity to adapt their behaviour to the demands of their work schedule. Adherence to a healthy lifestyle, according to some authors $(11,46)$, should be expected to moderate the effects of work schedule demands on health and may act as a personal resource (47-49) in three ways. First, it may improve health, thereby enhancing employees' resilience and capacity to manage stress. Second, it may reduce the physiological arousal that typically occurs in stressful situations. Third, it may encourage relaxation either during or shortly after psychological and physiological arousal, thereby preventing a build-up of tension. Cross-sectional studies among nurses, and longitudinal studies among other occupational groups, show positive relationships between healthy lifestyle factors and less fatigue, less psychological distress, higher work performance and higher mental health $(8,45,50-52)$. To date, there has been no published research focusing on the interaction between work schedule demands and healthy lifestyle in nursing.

\section{Job resources in nursing}

Jobs can offer resources to nurses to assist them to withstand work schedule demands. This study focuses specifically on two job resources, work schedule control and the work schedule fit with the nurses' private life.

Work schedule control (WSC) refers to the worker's ability to influence the duration, timing, and distribution of working hours (53). Perceived control is a resource that can diminish the impact of the work schedule on mental health and burnout, especially for female employees (36, 54-57). In a large prospective cohort study of health care workers, the combination of shiftwork and moderate or low control over working time was associated with less vitality, worse mental health, and more somatic stress compared to high control over working time (58).

Another aspect of the job concerns the extent to which the work schedule fits with nurses' private life, particularly in relation to leisure time, family and social circumstances, sleep and workleisure time balance $(34,59)$. This appeared to be an important concept. Peters et al., (12) found indications that the extent to which the work schedule fits with nurses' private life moderated the relationships between work schedule demands and both emotional exhaustion and health complaints. The extent to which their work schedule fits with private life is not only related to objective characteristics, such as duration of work and flexitime, but also to positive and negative consequences $(6,56)$. A large study among European nurses, the Nurses' Early Exit Study (NEXT study), indicated that it was not the work schedule itself, but rather the discrepancies between individuals' wishes and the schedule, that affected turnover intention (60) and highlighted the positive aspects of the work schedule in relation to the private life.

\section{Burnout and work engagement}

Burnout is a unique type of stress syndrome that includes emotional exhaustion, depersonalization (or cynicism), and diminished personal accomplishment $(39,61)$. Work engagement is a positive, work-related state of fulfilment that is characterized by vigour, dedication, and absorption (62). According to Bakker, Schaufeli, Leiter, and Taris (63), it can be seen as the opposite of burnout. Emotional exhaustion, the main dimension of burnout (64-66) and vigour are opposite ends of the energy dimension of work engagement, while cynicism and dedication are opposite ends of an underlying attitudinal dimension (67). The inclusion of work engagement reflects the growing interest in the benefits of work and not just in its negative effects.

\section{The research model}

It is widely assumed that shiftwork contributes to stress reactions and negative health effects in a comparable way to other occupational stressors and processes $(26,53,68)$. A considerable number of theories about work-related stressors and health have been developed in the past. In these models, causes and outcomes are more or less conceptually integrated and ordered 
into a causal pattern of relationships. A well-known example is the Job Demand-Control model (69). The most innovative aspect of this model was that psychological strains were considered a consequence of the interaction effects of job demands and job control. More recent developed models emphasize, merely build upon the COR theory, not only the effect of demands but also of resources on health effects, e.g. the Job Demand-Resources model (JD-R). According to this JD-R model, each occupation has its own specific risk factors associated with job-related stress and can be applied to various occupational settings, irrespective of the particular demands and resources involved (70). Elaborating on this JD-R model, we stated the following research model for studying the moderation effects of personal and job resources $(24,29,71)$. Resources are assumed to buffe the impact of job demands on job strain, including burnout. The interaction of job demands and resources affects engagement and burnout $(24,28)$. Hobfoll et al. (29) propose that resources are particularly used when demands are high.

The present study aims to identify and understand the role of these resources in order to develop or provide input for interventions to enhance nurses' work engagement and to prevent burnout.

In line with the theoretical and empirical findings above, the following hypotheses were formulated (and incorporated in the research model, see Figure 1).

Hypothesis 1: Work schedule demands predict higher emotional exhaustion.

Hypothesis 2a: Personal resources predict greater work engagement.

Hypothesis $2 b$ : Job resources predict greater work engagement.

Hypothesis 3a: Personal resources buffer the relationship between work schedule demands and emotional exhaustion.

Hypothesis $3 b$ : Job resources buffer the relationship between work schedule demands and emotional exhaustion.

Hypothesis 4a: Personal resources particularly predict work engagement under conditions of high work schedule demands.

Hypothesis $4 b$ : Job resources particularly predict work engagement under conditions of high work schedule demands.

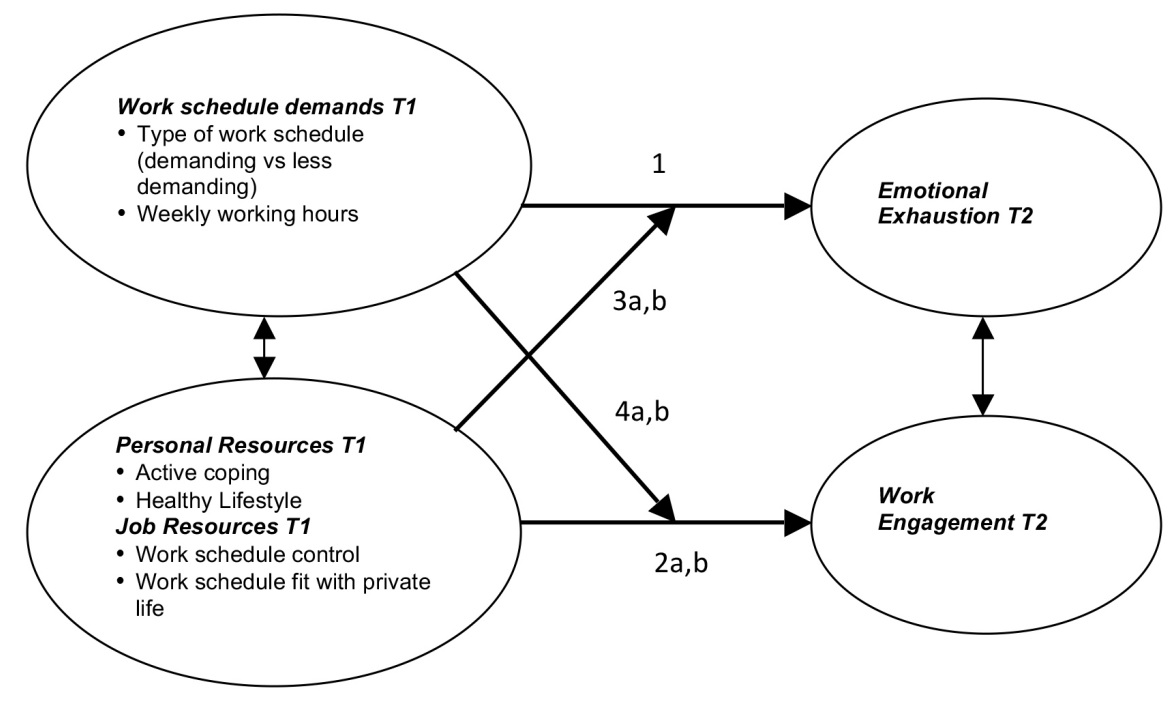

Figure 1: Research model (numbers refer to the hypotheses).

\section{METHOD}

\section{Design, population and procedure}

This longitudinal study included two waves of data collection using self-report questionnaires. The participants were nurses who worked on shifts or irregular working hours in residential care for the elderly, which accommodates clients with psycho-geriatric disorders and physical frailties. The three facilities that participated were included because the nurses' work schedules generally reflected nursing work schedules in the Netherlands. Questionnaires were sent to the home addresses of all nursing employees. The participants were asked to return them within two weeks. Reminders were sent to all participants two and three weeks after the initial distribution of the questionnaires. The two waves of data collection were one year apart (October 2009 and October 2010). This period was chosen because it was long enough to measure possible changes in individual scores and also to control for seasonal effects $(72,73)$. The study was not submitted to an ethical committee because, according to Dutch law (Wet Medisch-Wetenschappelijk Onderzoek met Mensen/Medica Research Involving Human Subjects Act), surveys only have to be submitted to an ethical committee in a limited number of situations, and does not apply to the present study. The study was approved by the management board of the homes involved. The participants were informed by individual letter and an institutional newsletter, they were free to refuse to participate and welcomed to ask questions and express concerns about the study any time. The questionnaires contained a code to identify participants the second time. Only an anonymous code remained in the final dataset. 
Return of a completed questionnaire was taken to imply consent. Data were stored anonymously, treated confidentially and the participants' privacy was guaranteed.

\section{Sample}

The total study population comprised 974 nurses who worked shifts and were employed in one of the three participating facilities. Although 'nurse' indicates normally the qualification leve of a registered nurse, the current research uses this term for nurses working in residential elder care in the Netherlands. This includes registered nurses, enrolled nurses, licensed vocational or practical nurses and nurse care helpers. In the Netherlands nurses working in residental elder care are comparable with respect of qualification level to Dutch nurses working in hospitals, home care, care for disabled people and mental health care but do have different psychosocial and physical demands (74). The proportion of registered nurses working in residential elder care varies between European countries with the Netherlands as a leading country with the highest proportion of registered nurses working in residential elder care (60). At Time 1, 498 questionnaires (51\%) were returned (see Figure 2). At Time 2, 291 questionnaires (58\%), and 30\% of the initial study population) were returned. Only fully completed questionnaires were analysed.

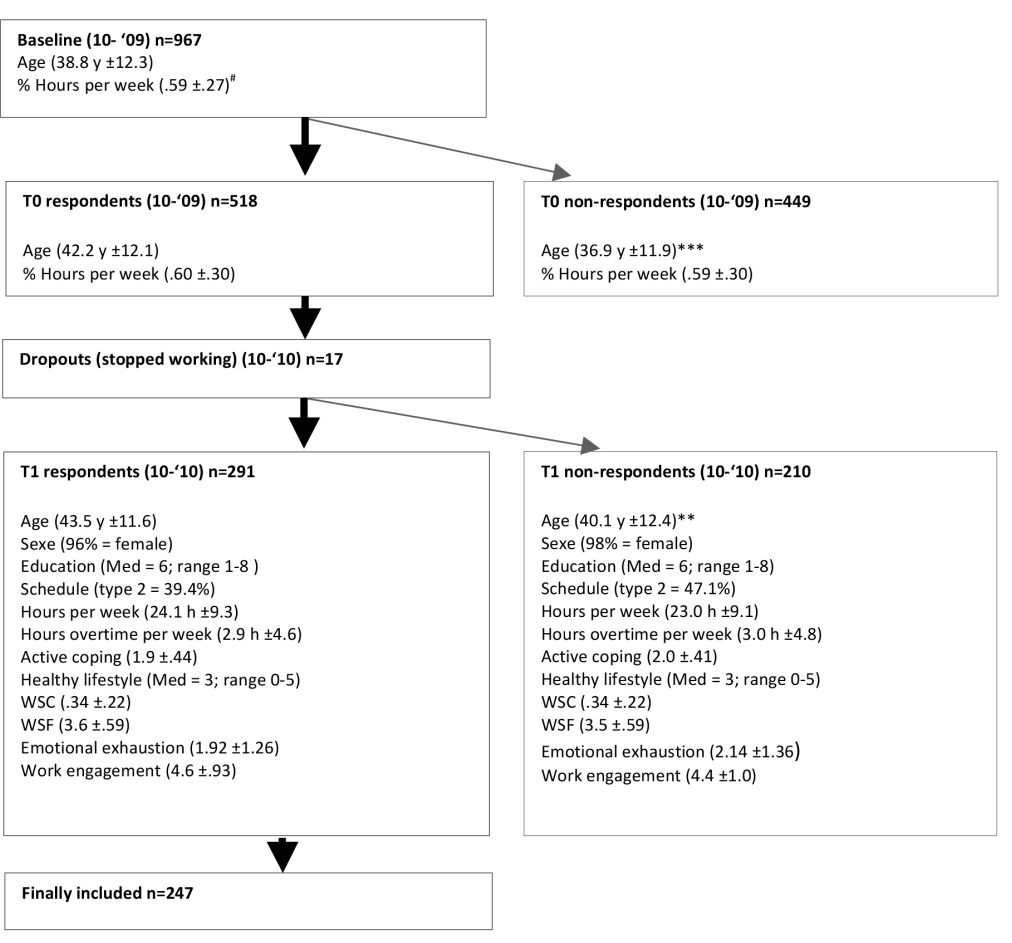

Figure 2: Flowchart of inclusion process and t-tests between respondents and non-respondents. \#=percentage of 36 fulltime work hours per week

${ }^{*} p<.05 .{ }^{*} p<.01 .{ }^{* * *} p<.001$.

$\mathrm{WSF}=$ Work schedule fit with private life; $\mathrm{WSC}=$ work schedule control.

\section{Measures}

Demands

To collect data on the characteristics of their work schedules, respondents were asked which shifts they worked (morning, afternoon and night shifts) and when these working days began and ended. They were also asked whether they worked shifts other than these standard morning, late and night shifts. Based on a new typology $(75,76)$ of work schedules, the schedules were initially classified into five types. LISREL (LInear Structural RELations, a statistical software package used for structural equation modeling) cannot deal with nominal data because it needs correlations to produce a variance-covariance matrix. Therefore, the schedules were subsequently classified into two types: a rotating schedule including morning, afternoon and night shifts (scored 1) and all other work schedules (scored 0 ). The second work schedule demand was the average number of weekly working hours, which was assessed with the following item: "How many hours are you contractually required to work each week?"

\section{Personal resources}

Two personal resources were assessed: active coping and adherence to a healthy lifestyle. Active coping style was assessed using the subscale of the Utrecht Coping List (short version) (77). This subscale assesses a direct and logical approach to problematic situations. It consists of five items that are scored on a 4-point Likert scale, ranging from 0 'seldom or never' to 3 'very often'. Participants are asked to indicate how often they cope with problems and stressful situations in the way described by each item, for example by 'Acting immediately when problems occur'. A higher score reflects a more active coping style. The internal consistency (Cronbach's alpha) was 0.76 at T1.

Healthy lifestyle was measured with a composite scale composed corresponding to the procedure used by Pronk et al. $(45,78)$ that provided information about five behaviours: physical activity, smoking, alcohol use, consumption of fruit or vegetables and quality of sleep. It provides an "optimal lifestyle index" (45). This optimal lifestyle index has shown to have sufficient construct validity and to be related to job and health related outcomes $(45,78-81)$. Each behaviour was classified as a binary variable. Meeting the norm for each behaviour was scored ' 1 ' and not meeting it was scored ' 0 '. Scores were summed to form a lifestyle index that ranged from 0 'low adherence' to 5 'high adherence', which reflected the healthiest lifestyle. The following behaviours were used:

- In accordance with the Dutch Standard for Healthy Exercise, physical activity was assessed as the number of days in a usual week that the nurse engaged in vigorous or moderate intensity activities (Kemper et al., 2000). The criterion was met if nurses engaged in $\geq 150$ minutes per week of moderate physical activity or engaged in $\geq 60$ minutes per week of vigorous activity.

- Smoking was assessed with the question "Do you smoke?". 
- Alcohol consumption was assessed using the average number of alcohol drinks per week. The criterion was met if women drunk not more than 7 units and if men drunk not more than 14 units of alcohol per week (82).

- Fruit and vegetable consumption was assessed by asking on how many days in a typical week more than 200 grams of fruits and vegetables were consumed. The criterion was met if seven days per week for both fruit and vegetables were consumed.

- Quality of sleep was assessed with the sleep quality scale in the Dutch Quality of Work Questionnaire [Vragenlijst Beleving en Beoordeling van de Arbeid (VBBA)], which contains 14 items, such as: "When I wake up in the night, it is hard for me to fall asleep again". Each item was scored as either 'yes' or 'no' and they were then averaged, with a higher score indicating more sleep complaints. The internal consistency (Cronbach's alpha) was 0.88 . The median split method (Med $=.21$ ) was then used to dichotomize this scale into high sleep quality and low sleep quality.

Job resources

Two job resources were assessed: work schedule control and the work schedule fit with nurses' private life.

Work schedule control (WSC) was measured with a scale that assesses perceptions of having choice and influence over starting and ending times, days off, breaks during the workday, swapping shifts and taking unpaid leave. It consisted of 10 items scored with either 1 ('yes') or 0 ('no') (76). Example items are: "Does your roster have a fixed pattern?" and "Is it easy to swap shifts?" The internal consistency (Cronbach's alpha) was 0.61 at T1, which was not increased by deleting items.

Satisfaction with Irregular Working hours (SIW) (59) was used to measure the extent to which the work schedule fits with nurses' private life, particularly in relation to leisure time, family situation, social circumstances, sleep and work-leisure time balance. The scale consists of fourteen items that are scored on a 5-point response scale ranging from 1 'entirely dissatisfied' to 5 'entirely satisfied', for example: 'How satisfied are you with the quality of your contact with family, friends and spouse given your irregular working hours?' The internal consistency (Cronbach's alpha) was 0.93 at T1.

\section{Outcome variables}

Emotional exhaustion was measured using a subscale of the Dutch version of the Maslach Burnout Inventory-General Survey (61). Emotional exhaustion seems the most characteristic burnout dimension in general and in nursing (64-66). The Maslach scale contains five items that are scored on a 7-point response scale ranging from 0 'never' to 6 'always'. An example of the items is "Working all day is really a strain for me". The internal consistency (Cronbach's alpha) was 0.90 at $\mathrm{T} 1$ and 0.91 at $\mathrm{T} 2$.
Work engagement was used to assess positive consequences. It was measured with the short version of the Utrecht Work Engagement Scale (UWES-9). It measures a positive, work-related state of fulfilment that is characterized by vigour, dedication and absorption (83). It consists of nine items and has been found to be reliable and valid (83). Participants responded on a seven-point Likert scale, ranging from 'never' (0) to 'always and daily' (6), with higher scores indicating greater work engagement. Examples of items are: "At my work I feel bursting with energy" (vigour), "My job inspires me" (dedication) and "Time flies when I am working" (absorption). The internal consistency (Cronbach's alpha) was 0.92 at $\mathrm{T} 1$ and $\mathrm{T} 2$.

\section{Data analyses}

The data were analysed in three steps. First, participant attrition was investigated by examining the differences in means or medians between participants in the panel group and those who participated the first time, but not the second (see Figure 2). Second, preliminary analyses (means, standard deviations, Cronbach's alphas, correlational analyses) were conducted. Third, the study hypotheses were tested in LISREL 8.8 using moderated structural equation modelling and the maximum likelihood method $(84,85)$

Because it is difficult to interpret multiplicative interaction terms in longitudinal research (86, 87) an incomplete two-wave panel design was used (73). The moderated SEM analyses followed the procedure described by Cortina, Chen and Dunlap (88) and used by Bakker, Hakanen, Demerouti, and Xanthopoulou (89). For each hypothesized interaction effect, a model was tested that included three types of exogenous variables: 1) type of work schedule or hours worked; 2) personal and job resources and 3) the multiplicative terms. Two endogenous variables were included (emotional exhaustion and work engagement at Time 2). To partial out their effects, the two outcome variables at Time 1 were included (cf. 73). In total, eight different models were tested for each possible interaction. Based on modification indices, the latent variable, emotional exhaustion at T2, loaded on the indicator variable, vitality at $\mathrm{T} 2$, which is also supported by theory (see 90). Figure 3 shows an example of the model that was applied separately for each of the four job resources.

Each exogenous variable had only one indicator according to the procedure described by Cortina et al., (88). The indicator of the latent interaction variable was included in the model by performing two analytic steps (91): (1) the variables were standardized to prevent multi-collinearity, and (2) the multiplicative terms of the demands and resources were computed from these variables.

The models included direct paths from the five exogenous variables to the two endogenous variables. The demands and resources variables were allowed to correlate, whereas correlations between demands and resources and the interaction term were constrained to zero. The residual errors of the two outcome variables were also allowed to correlate. Finally, the paths from the latent exogenous factors to their indicators were fixed with the square roots of the scale reliabilities, whereas the error variances of each indicator were set equal to the product of their variances and 
one minus their reliabilities. Manifest indicators of the two outcome variables at Time 1 were not used to completely comply with the Cortina procedure (88) and prevent identification problems. For a more detailed description of the calculation of the reliability score for the interaction term see Cortina et al. (88). According to MacCallum, Browne and Sugawara (92), the estimated power for exact fit was $>.70$ and for a more realistic close fit $>.95$ ( $d f=37, n=247$ ).

Several commonly-used fit indices were employed to assess the overall model fit $(84,85)$ : the chi-square statistic ( $\mathrm{X} 2$ ), the goodness-of-fit index (GFI), and the root mean square error of approximation (RMSEA). Finally, $t$-values were used to assess the significance of specific relationships.

A significant interaction effect is evident when the path coefficient from the interaction variable to the endogenous variables is statistically significant. To confirm this, the models were tested with and without the path from the latent interaction variable to the endogenous variables and the two models were compared on the basis of the chi-square difference statistic $(87,88)$. To examine the nature of the significant interaction terms, they were graphically displayed according to the method proposed by Aiken and West (91).

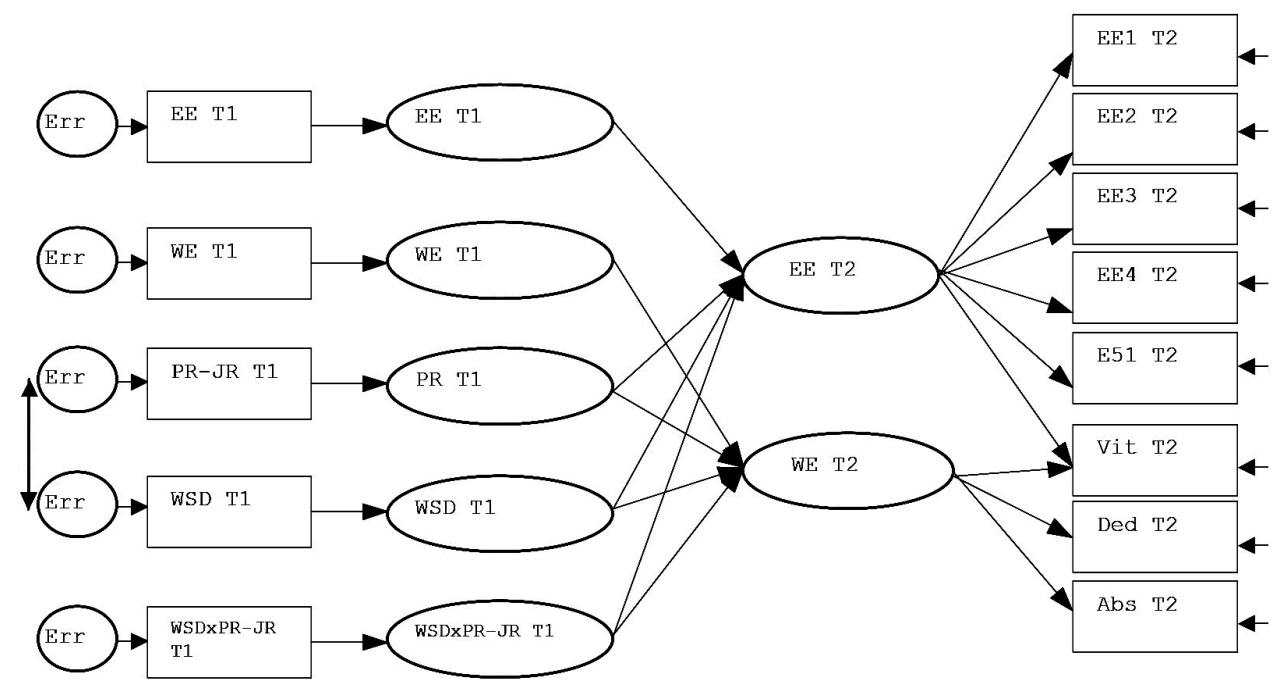

Figure 3: The analytical model.

$\mathrm{WE}=$ Work Engagement, $\mathrm{EE}=$ Emotional Exhaustion, Ded=dedication, Abs=absorption, Vit=vitality, PR=Personal Resource, JR= Job related resources, WSD=Work Schedule Demands, WSDxPR-JR=Interaction Work Schedule Demands and Personal or Job related Resource, T1=Time 1, T2=Time 2.

\section{RESULTS}

The final panel group ( $\mathrm{n}=247)$, consisting of participants who responded at both Time 1 and Time 2, comprised mainly women (96.7\%), which is typical for residential health care in the Netherlands. The mean age of the respondents at Time 1 was 43.04 years ( $S D=11.6)$. Fifteen respondents $(6.2 \%)$ had full-time contracts (36 contractual work hours a week), 43 (17.8\%) reported contractual working hours between 30 and 35 hours per week, 70 (28.3\%) between 24 and 30 hours and the remaining 119 $(47.7 \%)$ nurses worked 24 hours or less. The average period of employment in the current job was 9.4 years $(S D=8.0)$. Intermediate vocational education was the most common educational level (level 6; $63.6 \%)$. One hundred and forty-nine participants $(60.8 \%)$ had children living at home and $32.8 \%$ had children below the age of twelve. The average number of night shifts per month among the $48.5 \%$ of the respondents who worked nights was $4.4(S D=4.85)$. The average number of weekend shifts per month of the $95.1 \%$ of nurses who worked weekends was $4.1(S D=1.90)$. Correlational analyses showed that these background variables were only marginally related to the model variables and to the type of schedule (Table 1). Consequently, they were excluded from all further analyses.

\section{Descriptive statistics}

Table 1 shows the means, standard deviations, correlations, and internal consistencies (in the diagonal) of all variables in this study.

Table 1: Means, Standard Deviations, Internal Consistencies (Cronbach Alphas on the Diagonal), and correlations between the study variables $(\mathrm{N}=247)$.

\begin{tabular}{|c|c|c|c|c|c|c|c|c|c|c|c|c|c|c|}
\hline & $M /(M d)$ & SD & 1 & 2 & 3 & 4 & 5 & 6 & 7 & 8 & 9 & 10 & 11 & 12 \\
\hline 1 Age T1 & 43.04 & 11.7 & (n.a.) & & & & & & & & & & & \\
\hline 2 Education T1 & 6 & - & $-.155^{*}$ & (п.а.) & & & & & & & & & & \\
\hline $\begin{array}{l}3 \text { Type of schedule } \\
\text { T1 } 1=\text { type } 3 ; 0= \\
\text { others }\end{array}$ & 0 & - & $-.293^{*}$ & *.095 & (n.a.) & & & & & & & & & \\
\hline $\begin{array}{l}4 \text { Weekly working } \\
\text { hours T1 }\end{array}$ & 22.0 & 8.85 & .120 & -.022 & $.296 *$ & (п.а.) & & & & & & & & \\
\hline 5 Active coping $\mathrm{T} 1$ & 1.9 & 0.42 & -.080 & .054 & -.005 & .046 & $(0.76)$ & & & & & & & \\
\hline 6 Healthy lifestyle T1 & 3.0 & 1.00 & .024 & -.007 & $-169^{* *}$ & -.074 & $.150^{*}$ & (n.a.) & & & & & & \\
\hline $\begin{array}{l}7 \text { Work schedule } \\
\text { control T1 }\end{array}$ & 0.4 & 0.22 & .066 & -.080 & -.100 & $-.221^{1 *}$ & -.024 & -.009 & $(0.61)$ & & & & & \\
\hline $\begin{array}{l}8 \text { Work schedule fit } \\
\text { with private life T1 }\end{array}$ & 3.6 & 0.60 & -.021 & -.040 & $-.185^{* *}$ & $-191^{* *}$ & -.039 & 121 & $.313^{* *}$ & $(0.93)$ & & & & \\
\hline $\begin{array}{l}9 \text { Work engagement } \\
\mathrm{T} 1\end{array}$ & 4.6 & 0.92 & -.050 & -.102 & .080 & $.162^{*}$ & $.282^{* *}$ & $.164^{* *}$ & * $.189^{* *}$ & .022 & $(0.92)$ & & & \\
\hline $\begin{array}{l}10 \text { Emotional } \\
\text { exhaustion T1 }\end{array}$ & 1.9 & 1.23 & .085 & $-.140^{*}$ & $.154^{*}$ & .046 & $-360^{*}$ & *-.162* & " $-.127^{*}$ & -.037 & $-.218^{\circ}$ & (** & & \\
\hline $\begin{array}{l}11 \text { Work engagement } \\
\text { T2 }\end{array}$ & 4.4 & 0.93 & -.114 & $-.138^{*}$ & -.040 & .033 & $.318^{* *}$ & .177* & $.138^{*}$ & .031 & $.600^{*}$ & " $-.224^{4 *}$ & " $(0.92)$ & \\
\hline $\begin{array}{l}12 \text { Emotional } \\
\text { exhaustion T2 }\end{array}$ & 2.0 & 1.28 & $.138^{*}$ & $-.150^{*}$ & $.227^{* *}$ & .047 & $-.376^{*}$ & *-.171* & " -.067 & -.001 & -.099 & $.574^{* *}$ & $-.339^{* *}$ & $(0.91)$ \\
\hline
\end{tabular}

The two work schedule demands (variables 3 and 4) were at best weakly correlated with the personal and job resources (variables 5 to 8 ) and work engagement and emotional exhaustion at T1 and T2 
(variables 9 to 12). Similarly, except for satisfaction with irregular working hours, the personal and job resources variables were at best weakly correlated to work engagement and emotional exhaustion. Of all the correlations between personal and job resources, only the inter-correlation between satisfaction with irregular working hours and work schedule control was moderate; the other variables were correlated weakly or not at all. Work engagement at T1 and T2 was strongly correlated, as was emotional exhaustion at T1 and T2. There were only weak negative correlations between work engagement and emotional exhaustion at $\mathrm{T} 1$ and at $\mathrm{T} 2$.

\section{Inferential statistics}

Tables 2 and 3 show the results of the MSEM analyses.

Table 2: Results of Moderated Structural Equation Modeling: Interactions of type of work schedule and resources $(\mathrm{N}=247)$

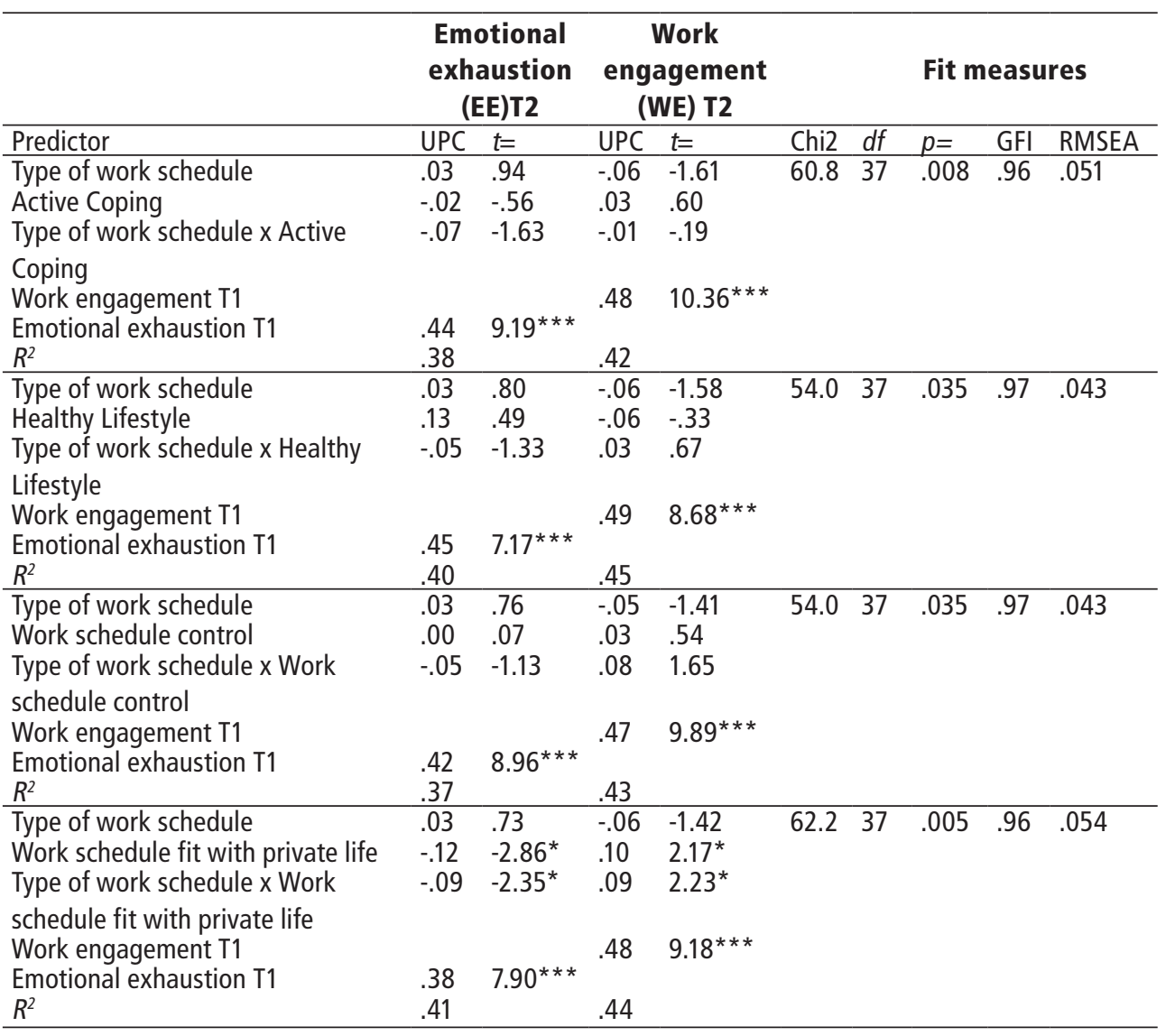

UPC = unstandardized path coefficient; GFI = goodness-of-fit index; RMSEA =root-mean-square error of approximation; $\Delta \mathrm{Chi}^{2}=$ Chi'difference test of the model without the interaction term.

${ }^{*} p<.05 .{ }^{* *} p<.01$. ${ }^{* *} p<.001$
Table 3: Results of Moderated Structural Equation Modeling: Interactions of hours worked and personal resources $(\mathrm{N}=247)$

\begin{tabular}{|c|c|c|c|c|c|c|c|c|c|}
\hline \multirow[b]{2}{*}{ Predictor } & \multicolumn{2}{|c|}{$\begin{array}{c}\text { Emotional } \\
\text { exhaustion } \\
\text { T2 }\end{array}$} & \multicolumn{2}{|c|}{$\begin{array}{c}\text { Work } \\
\text { engagement } \\
\text { T2 }\end{array}$} & \multirow[b]{2}{*}{ Chi2 } & \multicolumn{4}{|c|}{ Fit Measures } \\
\hline & UPC & $t=$ & UPC & $t=$ & & $d f$ & $p=$ & GFI & RMSEA \\
\hline Hours worked per week & .09 & $2.46^{*}$ & -.05 & -1.30 & 56.2 & 37 & .022 & .97 & .046 \\
\hline Active Coping & -.01 & -.14 & .03 & .70 & & & & & \\
\hline $\begin{array}{l}\text { Hours worked per week x Active } \\
\text { Coping }\end{array}$ & .04 & .86 & .03 & .57 & & & & & \\
\hline Work engagement T1 & & & .47 & $10.30^{* * *}$ & & & & & \\
\hline Emotional exhaustion T1 & .42 & $8.82^{* * *}$ & & & & & & & \\
\hline$R^{2}$ & .39 & & .42 & & & & & & \\
\hline Hours worked per week & .14 & 1.00 & -.08 & -.65 & 50.9 & 36 & .051 & .97 & .041 \\
\hline Healthy Lifestyle & .07 & .42 & -.03 & -.26 & & & & & \\
\hline $\begin{array}{l}\text { Hours worked per week x } \\
\text { Healthy Lifestyle }\end{array}$ & .04 & 1.07 & -.01 & -.28 & & & & & \\
\hline Work engagement T1 & & & .48 & $8.76^{* * *}$ & & & & & \\
\hline Emotional exhaustion T1 & .42 & $8.94^{* * *}$ & & & & & & & \\
\hline$R^{2}$ & .40 & & .41 & & & & & & \\
\hline Hours worked per week & .09 & $2.38^{*}$ & -.05 & -1.39 & 54.0 & 37 & .035 & .97 & .043 \\
\hline Work Schedule Control & -.01 & -.29 & .03 & .69 & & & & & \\
\hline $\begin{array}{l}\text { Hours worked per week x Work } \\
\text { schedule control }\end{array}$ & .10 & $1.98^{*}$ & .03 & .52 & & & & & \\
\hline Work engagement T1 & & & .46 & $9.66^{* * *}$ & & & & & \\
\hline Emotional exhaustion T1 & .41 & $8.70^{* * *}$ & & & & & & & \\
\hline$R^{2}$ & .41 & & .41 & & & & & & \\
\hline Hours worked per week & .12 & 1.04 & -.10 & -.65 & 48.8 & 34 & .048 & .97 & .042 \\
\hline $\begin{array}{l}\text { Work schedule fit with private } \\
\text { life }\end{array}$ & .01 & .13 & -.03 & -.23 & & & & & \\
\hline $\begin{array}{l}\text { Hours worked per week } x \text { Work } \\
\text { schedule fit with private life }\end{array}$ & -.10 & $-2.39^{*}$ & .10 & $2.10^{*}$ & & & & & \\
\hline Work engagement T1 & & & .48 & $6.70^{* * *}$ & & & & & \\
\hline Emotional exhaustion T1 & .38 & $8.33^{* * *}$ & & & & & & & \\
\hline$R^{2}$ & .44 & & .46 & & & & & & \\
\hline
\end{tabular}

$\mathrm{UPC}=$ unstandardized path coefficient; $\mathrm{GFI}=$ goodness-of-fit index; RMSEA =root-mean-square error of approximation; $\Delta \mathrm{Chi}^{2}=$ Chi ${ }^{2}$ difference test of the model without the interaction term. ${ }^{*} p<.05 .{ }^{* *} p<.01 .{ }^{* * *} p<.001$ 


\section{Direct Relationships (hypotheses 1 and 2)}

Overall, the RMSEA and GFl indicated good model fit. Both work engagement and emotional exhaustion at T1 were strongly and positively related to work engagement and emotional exhaustion at T2. Working in a specific type of work schedule did not predict work engagement or emotional exhaustion at T2. Weekly working hours predicted emotional exhaustion at T2 positively in two models: the more hours nurses worked at T1, the more emotionally exhausted they were at $\mathrm{T} 2$. Of the personal and job resources, only satisfaction with irregular working hours confirmed our hypothesis and predicted work engagement and emotional exhaustion at $\mathrm{T} 2$. This implies that hypotheses 1 and $2 \mathrm{~b}$ were both partially supported.

Interactions between work schedule demands and personal and job resources (hypotheses 3 and 4)

The results of the MSEM analyses provided support for the interactions between work schedule control and weekly working hours and satisfaction with irregular working hours and both work schedule demands. Work schedule control did not buffer, but reinforced the effect of weekly working hours on emotional exhaustion; the effect of weekly working hours on emotional exhaustion was the strongest when work schedule control was high. Satisfaction with irregular working hours buffered the effect of the type of work schedule and weekly working hours on emotional exhaustion. Satisfaction with irregular working hours predicted work engagement when the type of work schedule and weekly working hours were demanding.

In a final step, suggested by Cortina et al. (88), the model was tested without the paths from the interaction terms to work engagement and emotional exhaustion (T2), allowing a Chi2-difference test in fit between the model with and without the paths. In all five cases, elimination of the paths resulted in a significant chi-square difference test $(p<.05 ; d f=1)$, indicating that the models without the path from the latent interaction variable to the endogenous variables had a significantly worse fit. These findings further supported the interaction effects.

To test hypothesis $3 \mathrm{~b}$ in more detail, figure 4 shows a graphical representation (91) of the significant effect of weekly working hours on emotional exhaustion at T2 within high (+1SD) and low (-1SD) work schedule control subgroups. An increase in hours worked each week caused higher emotional exhaustion at T2 when work schedule control was high (+1SD) compared with when work schedule control was low (-1SD). To further test hypothesis $3 \mathrm{~b}$ in more detail, figures 5 and 6, show a graphical representation (91) of the significant buffer effect. The buffer interactions showed a similar pattern. For nurses with high work schedule demands (type 3 schedule) (Figure 5), low satisfaction with irregular working hours (-1SD) caused higher emotional exhaustion at T2 compared with nurses with high satisfaction with irregular working hours (+1SD). An increase in hours worked each week (Figure 6) caused higher emotional exhaustion at T2 when satisfaction with irregular working hours was low (-1SD) compared with when satisfaction with irregular working hours was high (+1SD).

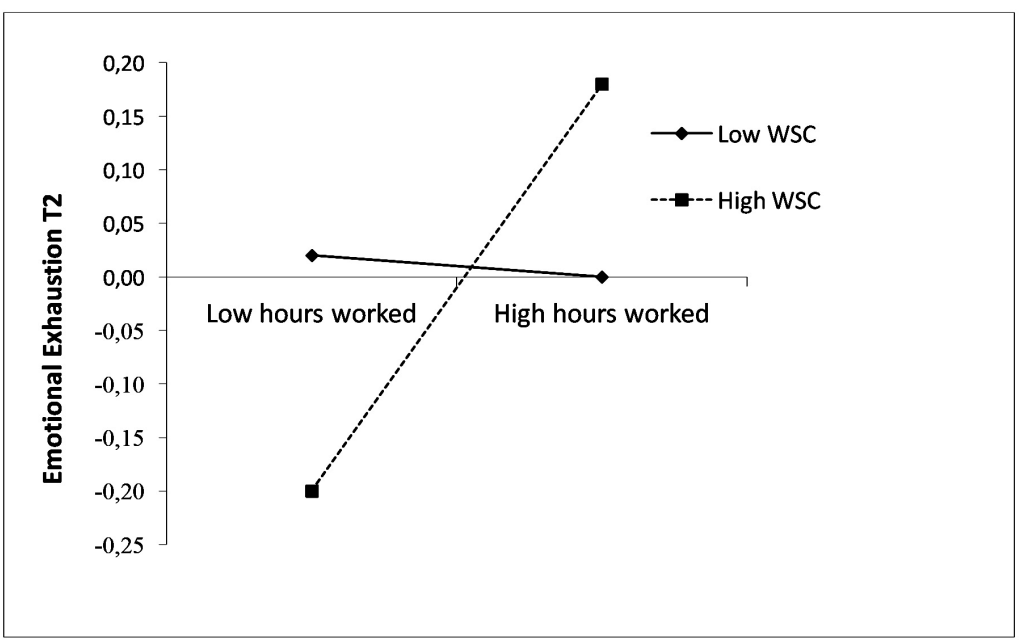

Figure 4: Work schedule control (WSC) moderates the effect of hours worked each week on emotiona exhaustion on $\mathrm{T} 2$

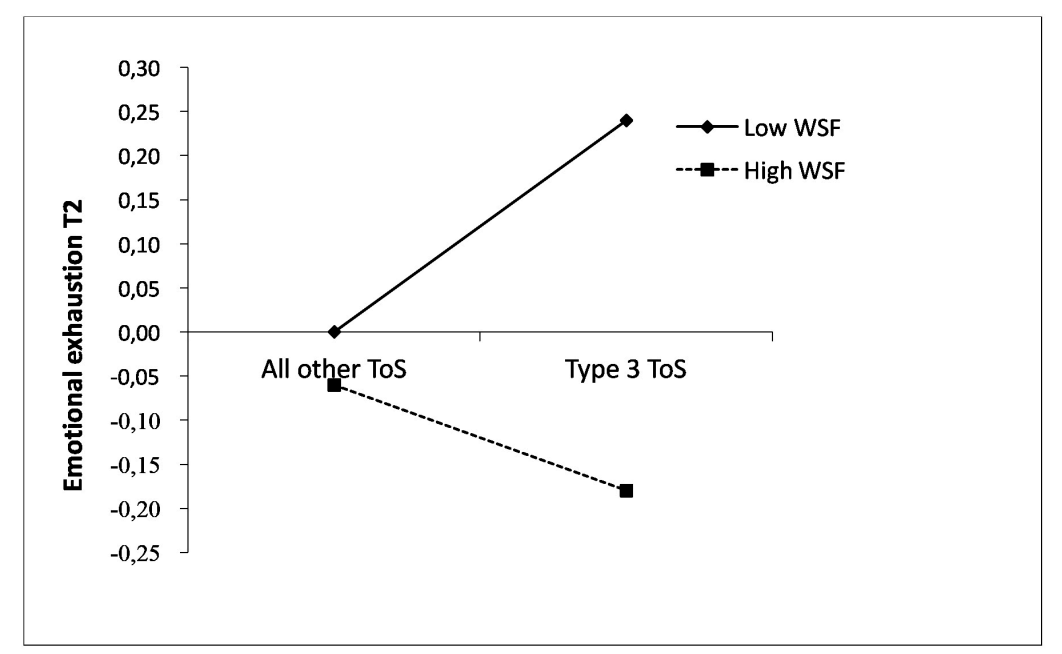

Figure 5: The work schedule fit with private life (WSF) buffers effect of type of schedule (ToS) on emotional exhaustion on $\mathrm{T} 2$ 


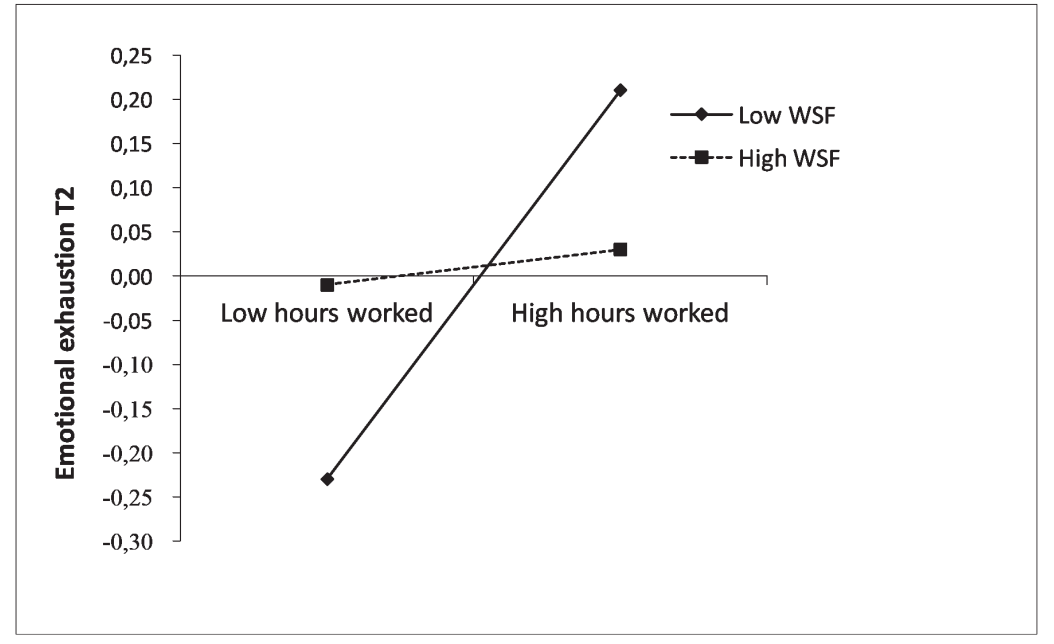

Figure 6: The work schedule fit with private life (WSF) buffers effect of hours worked each week on emotional exhaustion on $\mathrm{T} 2$

To test hypothesis $4 \mathrm{~b}$ in more detail, Figures 7 and 8 show a graphical representation of the significant interaction effects; the effect of resources on work engagement at T2 within high (+1SD) and low (-1SD) work schedule demands subgroups. These interactions showed similar patterns. Satisfaction with irregular working hours (Figure 7) caused higher work engagement at T2 for those with high work schedule demands (type 3 schedule) compared with those with low work schedule demands (all other types of work schedule). Satisfaction with irregular working hours caused a higher work engagement at $\mathrm{T} 2$ when the hours worked weekly were high (+1SD), compared with when the hours worked weekly were low (-1SD) (Figure 8).

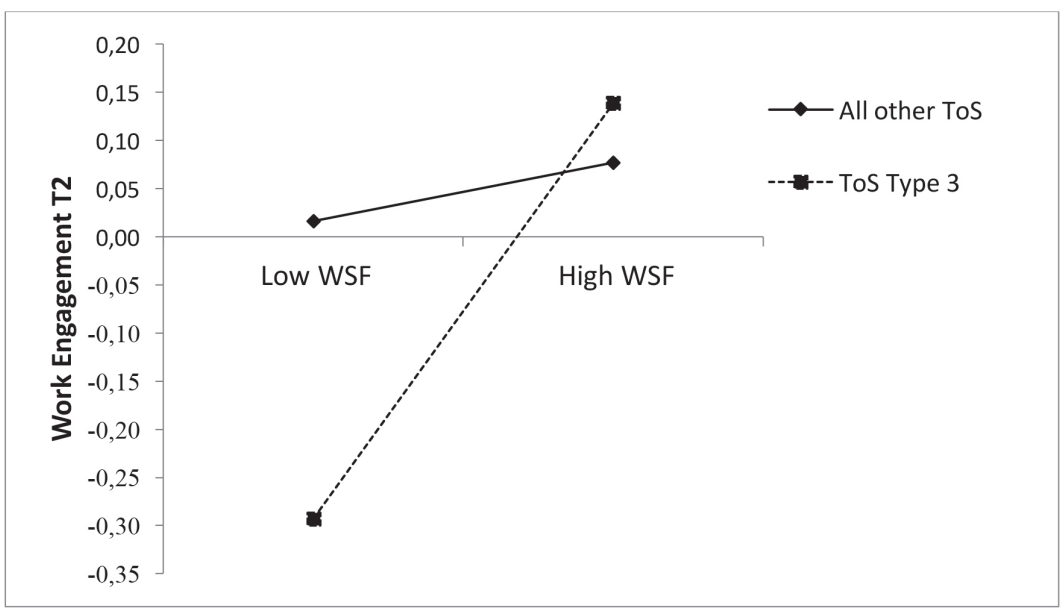

Figure 7: Type of schedule (ToS) moderates the effect of the work schedule fit with private life (WSF) on work engagement on $\mathrm{T} 2$

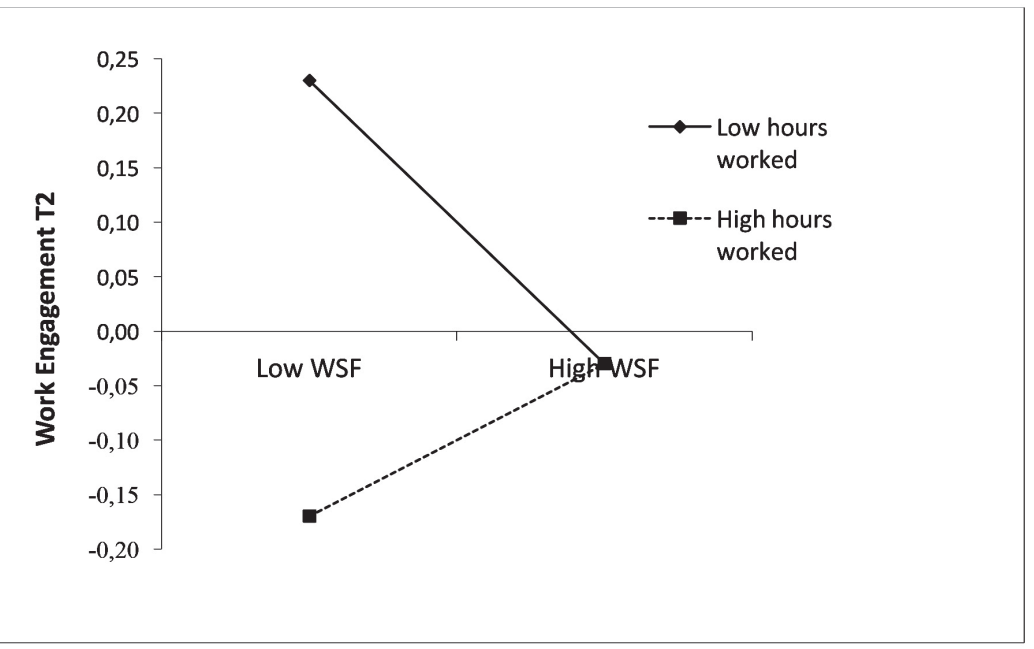

Figure 8: Hours worked per week moderates the effect of the work schedule fit with private life (WSF) on work engagement on $\mathrm{T} 2$

\section{DISCUSSION}

This longitudinal study of nurses working in residential care for the elderly examined whether personal and job resources moderate the relationships between work schedule demands and two work related health outcomes: work engagement and emotional exhaustion. Generally, few interaction effects were found. However, the extent to which the work schedule fits with nurses' private life appeared to enhance resilience to the two work schedule demands. With respect to the hypotheses about direct longitudinal effects (Hypothesis 1, 2a and 2b), only weekly working hours at Time 1 were related to greater emotional exhaustion one year later. The work schedule fit with nurses' private life and work schedule control were both associated with work engagement in an earlier study (12). However, in the present study, the work schedule fit with nurses' private life was the only job resource directly linked to work engagement one year later. This result could be partially explained by statistical power. Work engagement and emotional exhaustion at Time 1 were included to correct for stability effects and explained between $37 \%$ and $48 \%$ of the variance in work engagement and emotional exhaustion at $\mathrm{T} 2$.

Hypothesis $3 b$, concerning the buffering effect of job resources, was partially confirmed. The work schedule fit with nurses' private life buffered the relationships between the type of work schedule and weekly working hours on the one hand and emotional exhaustion one year later on the other. Consistent with the hypothesis, a demanding work schedule, the rotating three shift schedule and longer weekly working hours were associated with more emotional exhaustion when the work schedule fit with nurses' private life was low. The work schedule fit with of one's private 
life appeared to be particularly relevant when demands were high. These findings are in line with the buffering hypothesis in the JD-R model (28) and the Demand-Induced Strain Compensation (DISC) model (93). They are also consistent with the proposition that resources are most effective when they are closely matched to the specific stressor (30). Nurses' work schedule fit with their private life seems an important buffer of negative effects of work schedule demands; that is, the number of weekly working hours and the type of work schedule. Previous research suggests that perceived fit between the work schedule and social time with family is a valuable resource for nurses $(11,94)$.

Hypothesis $4 b$, concerning the effect of the interaction between work schedule demands and job resources on work engagement one year later, was confirmed. These findings imply that a work schedule that fits with nurses' private life results in higher work engagement, especially when work schedule demands are high. In line with COR theory (95) and for example the JD-R model $(28,89)$, it indicates that work schedules that fit nurses' private life assists nurses to deal with high work schedule demands. They are likely to use their non-work time for recovery, for example by taking part in social or active leisure activities. This study indicated that a work schedule that fits with their private life is less important with respect to work engagement when the work schedule demands are low.

Hypothesis 3b, regarding the buffering role of the work schedule fit with nurses' private life, was also supported. The effect of the interaction of work schedule control and weekly working hours on emotional exhaustion one year later was surprising. The relationship between weekly hours and higher emotional exhaustion was strongest when nurses reported high work schedule control. However, previous studies also reported inconsistent findings regarding control (89, 96, 97). It is possible that nurses may perceive a greater ability to schedule their own work as an extra burden rather than a resource, especially in a profession where starting and ending times are static and collaboration with colleagues is necessary to swap work schedules (97). This interpretation is consistent with a former study by Peters et al. (12) in which nurses with higher perceived work schedule control reported more health complaints than those with lower work schedule control. More work schedule control could also be linked to more home or family related demands (98). In a working population consisting mainly of women, traditionally the caregivers, this could lead to more various forms of domestic care, such as care responsibilities rather than increased capacity to recover and manage existing work and family demands $(99,100)$. An alternative explanation for these findings could be that work schedule control interacts with other job resources. De Rijk et al. (39) showed that a three-way interaction of job demands, job control and active coping affected emotional exhaustion. Only nurses with high active coping seemed to benefit from job control in that study. This three-way interaction could not be tested in our study using the moderated SEM analyses according to the procedure described by Cortina et al., (88). Although De Rijk et al. in their study used a more generic form of job control, it is possible that nurses with a more active coping style actively use their work schedule control to swap shifts or use breaks for activities that aid recovery, such as exercise.

Hypotheses $3 a$ and $4 a$ were not confirmed. Although active coping is generally seen as an effective way to deal with job demands (37), no direct or buffering effect was found in this study, supporting other longitudinal findings $(40,101)$. Regarding hypothesis 4 a there was no relationship between healthy lifestyle and work engagement and the interaction between the two did not affect the outcome variables. It is difficult to compare these results with other empirical findings because operationalizations of lifestyle vary widely. Nevertheless, there are some possible explanations. First, the one-year interval between Time 1 and Time 2 in this study was probably not sufficient to affect work engagement. No effects were found from a combined lifestyle program in a RCT on vitality, work engagement, productivity, and sick leave after 6- and 12-months (102), but physical activity can attenuate burnout and depression in the long run (103). Second, individual health-related behaviours, such as smoking, physical activity and alcohol abuse, have been found to have their own specific (time related) effects on health, disability pension and cardiovascular disease (104, 105), implying that a healthy lifestyle attributes more to physical health than to work engagement. Thirdly, there is a possibility that nurses' work engagement leads to health-related behaviour instead of the other way around. In cross-sectional research the degree of adherence to optimal lifestyle is associated with positive performance, general health and mental health $(45,51,106)$. Engaged nurses may be more proactive and take opportunities to pursue a healthy lifestyle. However, due to the incomplete panel design, it is not possible to prove reversed causation effects (107).

\section{Limitations of the study}

Some limitations of the present study should be noted. Although the variables under examination did not differ significantly between the respondents and non-respondents, non-respondents were slightly younger. The effect size was small $(d=0.29)$, but this could indicate non-response bias. On the other hand, there was positive evidence regarding representativeness. The respondents' age, sex, average weekly working hours and number of years in their current jobs were similar to those of nurses working in comparable facilities in the Netherlands (108).

A second limitation is that self-report measures were used. However, the bivariate correlations were not unusually high, different scale ranges were used, Harman's single factor test did not explain a large portion of variance (31\%) and the results of controlling for the effects of an unmeasured latent methods factor in Lisrel (109) suggest that common method variance is not a serious threat to the findings. Nevertheless, in future studies it may be valuable to include more objective outcome variables, such as registered sick leave data.

An explanation for the relatively small number of direct cross-lagged relationships and interaction effects may be found in the statistical technique that was used. The cross-lagged effects might have been underestimated because of correction of stability effects and because of the time lag 
used (107). Emotional exhaustion and work engagement have been shown to be stable across long periods $(110,111)$.

The scales generally showed good reliability. The work schedule control scale had just sufficient internal consistency at T1 ( $\alpha=.61)$ even though there is evidence it has good construct validity and it measures schedule control in accordance with findings of Nijp and colleagues (112). The implications of this limitation for the present findings are unclear, but might have led to underestimation of interaction effects. Furthermore, studies to further test the reliability and validaty of the healthy lifestyle index are necessary.

\section{CONCLUSION AND IMPLICATIONS}

This study shows that when nurses report that their (irregular) work schedules fit with their private lives, they suffer less from decreasing work engagement and emotional exhaustion due to work schedule demands. The work schedule fit with nurses' private life, a job resource more proximal to work schedules appeared to be more important for nurses' wellbeing than personal resources that were more distal. The other job resource examined, work schedule control, and the personal resources, active coping and healthy lifestyle, did not buffer the negative effects of work schedule demands. Moreover, nurses who experienced more work schedule control showed higher emotional exhaustion when weekly working hours were high.

The present findings have implications for future research and practice. More longitudinal research should be conducted on the potential interaction effects of job resources and work schedule demands on work engagement and emotional exhaustion among nurses. Because personal resources did not interact with work schedule demands, more research is needed to elucidate the role of personal resources in adapting to shiftwork. It is possible that personal resources mediate the relation between work schedule demands, job resources and work engagement (24). The present study also highlights, the idea that specific job demands and job resources (in this case, the work schedule fit with private life), should match to produce moderating effects on health $(31,93)$. It also showed the value of using the fit of the work schedule with nurses' private life to help explain the effects of shiftwork on health. Finally, research is needed to clarify the role of work schedule control as a universally beneficial tool to promote health among nurses (112). More research is needed to find out who gains from different levels of work schedule control.

The questionnaire used for measuring the experienced fit between the nurses' work schedule and their private life (SIW) and the categorization of work schedule types could prove to be a valuable tool for managers to assist them to enhance the fit between nurses' social life and their shifts. It may provide a useful framework for discussions between supervisors and nurses aimed at identifying work schedules with good fit. Furthermore, workplace interventions should focus not only on schedule-related characteristics, but also on resources. Therefore, nurses' evaluations of how their work schedules fit with their leisure activities, family situation, social circumstances, and work-leisure balance should be monitored which allow them to choose between work schedules to enhance fit.

It would be valuable to evaluate the SIW questionnaire, and confirm the present findings, in other occupational groups with irregular work schedules. Suitable groups include police officers and blue-collar workers, who not only differ from nurses in job demands, but also in socio-demographic characteristics. 


\section{REFERENCES}

1. Demerouti E, Bakker AB, Nachreiner F, Schaufeli WB. A model of burnout and life satisfaction amongst nurses. Journal of Advanced Nursing. 2000;32(2):454-64.

2. McVicar A. Workplace stress in nursing: a literature review. Journal of Advanced Nursing. 2003 Dec;44(6):633-42

3. Brown DL, Feskanich D, Sanchez BN, Rexrode KM, Schernhammer ES, Lisabeth LD. Rotating Night Shift Work and the Risk of Ischemic Stroke. Am J Epidemiol. 2009 June 1, 2009;169(11):1370-7.

4. Burch JB, Tom J, Zhai YS, Criswell L, Leo E, Ogoussan K. Shiftwork impacts and adaptation among health care workers. Occup Med-0xf. [Article]. 2009 May;59(3):159-66.

5. Jamal M. Burnout, stress and health of employees on non-standard work schedules: a study of Canadian workers. Stress and Health. 2004;20(3):113-9.

6. Nabe-Nielsen K, Kecklund G, Ingre M, Skotte J, Diderichsen F, Garde AH. The importance of individua preferences when evaluating the associations between working hours and indicators of health and well-being. Applied Ergonomics. 2010;41(6):779-86.

7. Puttonen S, Härmä M, Hublin C. Shift work and cardiovascular disease - pathways from circadian stress to morbidity. Scand J Work Environ Health. 2010 Mar;36(2):96-108.

8. Samaha E, Lal S, Samaha N, Wyndham J. Psychological, lifestyle and coping contributors to chronic fatigue in shift-worker nurses. Journal of Advanced Nursing. 2007;59(3):221-32.

9. Wisetborisut A, Angkurawaranon C, Jiraporncharoen W, Uaphanthasath R, Wiwatanadate P. Shift work and burnout among health care workers. Occup Med (Lond). 2014 Jun;64(4):279-86.

10. Taylor E, Briner RB, Folkard S. Models of shiftwork and health: An examination of the influence of stress on shiftwork theory. Human Factors. 1997;39(1):67-82.

11. Caruso CC, Bushnell T, Eggerth D, Heitmann A, Kojola B, Newman K, et al. Long working hours, safety and health: toward a National Research Agenda. Am J Ind Med. 2006 Nov;49(11):930-42.

12. Peters V, De Rijk AE, Engels J, Nijhuis F. The associations of objective and subjective work schedule characteristics with negative and positive consequences; a survey in the Netherlands. 20th Internationa Symposium on Shiftwork and Working Time "Biological mechanisms and risk management in the $24 \mathrm{~h}$ society" - Stockholm, Sweden, June 28-July 1, 20112011.

13. Pallesen S, Bjorvatn B, Mageroy N, Saksvik IB, Waage S, Moen BE. Measures to counteract the negative effects of night work. Scand J Work Environ Health. 2010 Mar;36(2):109-20.

14. Garrosa E, Moreno-Jiménez B, Rodríguez-Muñoz A, Rodríguez-Carvajal R. Role stress and persona resources in nursing: A cross-sectional study of burnout and engagement. International Journal of Nursing Studies. 2011;48(4):479-89.

15. Muecke S. Effects of rotating night shifts: literature review. Journal of Advanced Nursing. 2005 May;50(4):433-9.

16. Winwood PC, Winefield AH, Lushington K. Work-related fatigue and recovery: the contribution of age domestic responsibilities and shiftwork. Journal of Advanced Nursing. 2006;56(4):438-49.

17. Lipscomb JA, Trinkoff AM, Geiger-Brown J, Brady B. Work-schedule characteristics and reported musculoskeletal disorders of registered nurses. Scand J Work Environ Health. 2002 Dec;28(6):394-401.

18. Dall'Ora C, Griffiths P, Ball J, Simon M, Aiken LH. Association of $12 \mathrm{~h}$ shifts and nurses' job satisfaction burnout and intention to leave: findings from a cross-sectional study of 12 European countries. BM.
19. De Raeve L, Jansen NWH, Kant I. Health effects of transitions in work schedule, workhours and overtime in a prospective cohort study. Scand J Work Environ Health. 2007 Apr;33(2):105-13.

20. Geiger-Brown J, Muntaner C, Lipscomb J, Trinkoff A. Demanding work schedules and mental health in nursing assistants working in nursing homes. Work \& Stress. 2004;18(4):292-304.

21. Jansen N, Van Amelsvoort L, Kristensen T, Van den Brandt P, Kant I. Work schedules and fatigue: a prospective cohort study. Occupational and Environmental Medicine. 2003 June 2003:60(suppl 1):47-53.

22. Stimpfel AW, Sloane DM, Aiken LH. The longer the shifts for hospital nurses, the higher the levels of burnout and patient dissatisfaction. Health Aff (Millwood). [Comparative StudyMulticenter StudyResearch Support, N.I.H., Extramural Research Support, U.S. Gov't, P.H.S.]. 2012 Nov:31(11):2501-9.

23. Caruso CC, Hitchcock EM, Dick RB, Russo JM, Schmit JM. Overtime and Extended Work Shifts: Recen Findings on Illnesses, Injuries, and Health Behaviors. U S Department of Health and Human Services; Centers for Disease Control and Prevention, National Institute for Occupational Safety and Health. 2004.

24. Schaufeli WB, Taris TW. A Critical Review of the Job Demands-Resources Model: Implications for Improving Work and Health. 2014:43-68.

25. Tenkanen L, Sjoblom T, Härmä M. Joint effect of shift work and adverse life-style factors on the risk of coronary heart disease. Scand J Work Environ Health. 1998 Oct;24(5):351-7.

26. Totterdell P. Work schedules. In: Barling J, Kelloway E, Frone M, editors. Handbook of Work Stress, London: Sage; 2005.

27. Gorgievski MJ, Hobfoll SE. Work can burn us out and fire us up; Conservation of Resources in Burnout and Engagement. In: Halbesleben JRB, editor. Handbook of stress and burnout in health care. Hauppage, new York: Nova Publishers; 2008. p. pp. 7-22.

28. Bakker AB, Demerouti E. The Job Demands-Resources model: State of the art. Journal of Managerial Psychology. 2007;22(3):309-28.

29. Hobfoll SE, Johnson RJ, Ennis N, Jackson AP. Resource loss, resource gain, and emotional outcomes among inner city women. Journal of Personality and Social Psychology. 2003;84(3):632-43.

30. Van den Tooren $\mathrm{M}$, de Jonge J. Managing job stress in nursing: what kind of resources do we need? Adv Nurs. 2008 Jul;63(1):75-84.

31. Zacher H, Jimmieson NL, Winter G. Eldercare demands, mental health, and work performance: The moderating role of satisfaction with eldercare tasks. Journal of Occupational Health Psychology. 2012;17(1):52-64.

32. Simpson MR. Engagement at work: a review of the literature. Int J Nurs Stud. 2009 Jul;46(7):1012-24.

33. Wilson JL. The impact of shift patterns on healthcare professionals. Journal of Nursing Management. 2002;10(4):211-9.

34. Beutell NJ. Work schedule, work schedule control and satisfaction in relation to work-family conflict, work-family synergy, and domain satisfaction. Career Development International. 2010;15 (5):501 - 18.

35. Peeters MA, Rutte CG. Time management behavior as a moderator for the job demand-control interaction. Journal of Occupational Health Psychology. [Review]. 2005 Jan;10(1):64-75.

36. Tucker P, Knowles SR. Review of studies that have used the Standard Shiftwork Index: evidence for the underlying model of shiftwork and health. Applied ergonomics. 2008 Sep;39(5):550-64.

37. Schaufeli WB. Coping with job stress. In: Smelser NJ, Baltes PB, editors. The international encyclopedia of the social and behavioral sciences. Oxford, UK: Elsevier; 2001. p. 7983-7. 
38. Weigl M, Hornung S, Parker SK, Petru R, Glaser J, Angerer P. Work engagement accumulation of task social, personal resources: A three-wave structural equation model. Journal of Vocational Behavior. 2010;77(1):140-53

39. De Rijk AE, Le Blanc PM, Schaufeli WB, De Jonge J. Active coping and need for control as moderators of the job demand-control model: Effects on burnout. Journal of Occupational \& Organizational Psychology. [Article]. 1998;71(1):1-18

40. Garrosa E, Rainho C, Moreno-Jimenez B, Monteiro MJ. The relationship between job stressors, hardy personality, coping resources and burnout in a sample of nurses: a correlational study at two time points. International Journal of Nursing Studies. 2010 Feb;47(2):205-15.

41. Parkes KR. Coping, negative affectivity, and the work environment: Additive and interactive predictors of mental health. Journal of Applied Psychology. 1990;75(4):399-409.

42. Sasaki M, Kitaoka-Higashiguchi K, Morikawa Y, Nakagawa H. Relationship between stress coping and burnout in Japanese hospital nurses. Journal of Nursing Management. 2009;17(3):359-65.

43. Siegrist J, Rodel A. Work stress and health risk behavior. Scand J Work Environ Health. 2006 Dec;32(6):473-81

44. Ten Brummelhuis LL, Bakker AB. A resource perspective on the work-home interface: the work-home resources model. Am Psychol. 2012 0ct;67(7):545-56.

45. Pronk NP, Katz AS, Gallagher J, Austin E, Mullen D, Lowry M, et al. Adherence to optimal lifestyle behaviors is related to emotional health indicators among employees. Popul Health Manag. 2010 Apr;14(2):59-67.

46. Heerkens YF, Engels J, Kuiper C, Van der Gulden J, Oostendorp R. The use of the ICF to describe work related factors influencing the health of employees. Disabil Rehabil. 2004 Sep 2;26(17):1060-6.

47. Hobfoll SE. The Influence of Culture, Community, and the Nested-Self in the Stress Process: Advancing Conservation of Resources Theory. Applied Psychology. 2001;50(3):337-421.

48. Roe RA. Work performance. A multiple regulation perspective. In: Robertson GCIT, editor. International Review of Industrial and Organizational Psychology Chichester: Wiley; 1999. p. 231-335.

49. Steffy BD, Jones JW, Noe AW. The impact of health habits and life-style on the stressor-strain relationship: An evaluation of three industries. Journal of Occupational Psychology. [Article]. 1990;63(3):217-29.

50. Bultmann U, Kant IJ, Kasl SV, Schroer KA, Swaen GM, van den Brandt PA. Lifestyle factors as risk factors for fatigue and psychological distress in the working population: prospective results from the Maastricht Cohort Study. J Occup Environ Med. 2002 Feb;44(2):116-24.

51. Pronk NP, Martinson B, Kessler RC, Beck AL, Simon GE, Wang P. The association between work performance and physical activity, cardiorespiratory fitness, and obesity. J Occup Environ Med. 2004 Jan;46(1):19-25.

52. Winwood PC, Bakker AB, Winefield AH. An investigation of the role of non-work-time behavior in buffering the effects of work strain. Journal of Occupational and Environmental Medicine. 2007;49(8):862-71.

53. Härmä M. Workhours in relation to work stress, recovery and health. Scandinavian Journal of Work Environment \& Health. 2006 Dec;32(6):502-14

54. Ala-Mursula, Vahtera J, Linna A, Pentti J, Kivimäki M. Employee worktime control moderates the effects of job strain and effort-reward imbalance on sickness absence: the 10-town study. Journal of Epidemiology and Community Health. 2005 October 2005;59(10):851-7.

55. Bohle P, Willaby H, Quinlan M, McNamara M. Flexible work in call centres: Working hours, work-life conflict \& health. Applied Ergonomics. 2011 Jan;42(2):219-24.

56. Krausz M, Sagie A, Bidermann Y. Actual and Preferred Work Schedules and Scheduling Control as Determinants of Job-Related Attitudes. Journal of Vocational Behavior. 2000;56(1):1-11.
57. McNamara M, Bohle P, Quinlan M. Precarious employment, working hours, work-life conflict and health in hotel work. Applied Ergonomics. 2011 Jan;42(2):225-32

58. Nabe-Nielsen K, Garde AH, Albertsen K, Diderichsen F. The moderating effect of work-time influence on the effect of shift work: a prospective cohort study. Int Arch Occup Environ Health. 2011 Jun;84(5):551-9.

59. Peters V, De Rijk AE, Boumans NP. Nurses' satisfaction with shiftwork and associations with work, home and health characteristics: a survey in the Netherlands. J Adv Nurs. 2009 Dec;65(12):2689-700.

60. Hasselhorn H-M, Oginska H, Tackenberg P, Pokorski J, Estryn-Behar M, Camerino D, et al. Nurses Early Exit Study - (NEXT) - scientific results. Wuppertal: University of Wuppertal2005.

61. Schaufeli WB, Van Dierendonck D. Handleiding van de Utrechtse Burnout Schaal (UBOS). Lisse: Swets Test Services; 2000

62. Schaufeli WB, Bakker AB. Preliminary Manual UWES; Utrecht Work Engagement Scale. Utrecht University: Occupational Health Psychology Unit; 2004.

63. Bakker AB, Schaufeli WB, Leiter MP, Taris TW. Work engagement: An emerging concept in occupational health psychology. Work \& Stress. 2008;22(3):187-200.

64. Goodman EA, Boss RW. The phase model of burnout and employee turnover. Journal of Health \& Human Services Administration. [Article]. 2002 Summer/Fall2002;25(1/2):33-47.

65. Tourigny L, Baba VV, Han J, Wang X. Emotional exhaustion and job performance: the mediating role of organizational commitment. The International Journal of Human Resource Management. 2013;24(3):514-32.

66. Wright TA, Cropanzano R. Emotional exhaustion as a predictor of job performance and voluntary turnover. Journal of Applied Psychology. 1998;83(3):486-93.

67. Demerouti $E$, Bakker AB, Voydanoff P. Does home life interfere with or facilitate job performance? European Journal of Work and Organizational Psychology. 2010;19(2):128-49.

68. Olsson K, Kandolin I, Kauppinen-Toropainen K. Stress and coping strategies of three-shift workers. Le Travail Humain. 1990;53(2):175-88

69. Karasek RA, Theorell T. Healthy Work: Stress, Productivity and the Reconstruction of Working Life. New York: Basic Books; 1990

70. Demerouti E, Bakker AB. The Job Demands-Resources model: Challenges for future research. SA Journa of Industrial Psychology/SA Tydskrif vir Bedryfsielkunde. 2011;37(2):1-9.

71. Demerouti E, Bakker AB, Nachreiner F, Schaufeli WB. The job demands-resources model of burnout. J Appl Psychol. 2001 Jun;86(3):499-512.

72. De Lange AH, Taris TW, Kompier MAJ, Houtman ILD, Bongers PM. The relationships between work characteristics and mental health: examining normal, reversed and reciprocal relationships in a 4-wave study. Work \& Stress. 2004 2004/04/01;18(2):149-66.

73. Zapf D, Dormann C, Frese M. Longitudinal studies in organizational stress research: A review of the literature with reference to methodological issues. Journal of Occupational Health Psychology. 1996;1(2):145-69.

74. Simon M, Tackenberg P, Nienhaus A, Estryn-Behar M, Conway PM, Hasselhorn HM. Back or neck-painrelated disability of nursing staff in hospitals, nursing homes and home care in seven countries--results from the European NEXT-Study. International Journal of Nursing Studies. [Comparative Study Research Support, Non-U.S. Gov't]. 2008 Jan;45(1):24-34.

75. Peters V, Engels JA, De Rijk AE, Nijhuis FJ. Sustainable employability in shiftwork: related to types of work schedule rather than age. Int Arch Occup Environ Health. 2015 Jan 13. 
76. Peters V, Houkes I, De Rijk AE, Bohle PL, Engels JA, Nijhuis FJN. Which resources moderate the effects of demanding work schedules on nurses working in residential elder care? A longitudinal study. Internationa Journal of Nursing Studies. 2016;58:31-46.

77. Schreurs PJ, Tellegen B, Willige GV. Gezondheid, stress en coping: de ontwikkeling van de Utrechtse coping-lijst. Gedrag: Tijdschrift voor Psychologie. 1984;12(1-2):101-17.

78. Pronk N. An Optimal Lifestyle Metric: Four Simple Behaviours That Affect Health, Cost, and Productivity. ACSM's health \& fitness journal. 2012;16(3):39-43.

79. Koenders PG, van Deursen CGL. Minder verzuim bij verbetering leefstijl. TVBV. 2009 2009/01/01;17(1):3-9.

80. van Deursen C, Koenders P. Een gezonde leefstijl geeft een lager verzuim. ESB Economisch statistische berichten. 2007;92(4515):468-70

81. Lenz TL, Gillespie ND, Skradski JJ, Viereck LK, Packard KA, Monaghan MS. Development of a Composite Lifestyle Index and Its Relationship to Quality of Life Improvement: The CLI Pilot Study. ISRN Preventive Medicine. 2013;2013:7.

82. Health Council of the Netherlands. Guidelines for a Healthy Diet 2006. Netherlands HCot, editor. The Hague: Health Council of the Netherlands; 2006.

83. Schaufeli WB, Bakker AB, Salanova M. The Measurement of Work Engagement With a Short Questionnaire. Educational and Psychological Measurement. 2006 August 1, 2006;66(4):701-16.

84. Diamantopoulos A, Siguaw JA. Introducing LISREL : a guide for the uninitiated. London: Sage; 2002.

85. Schumacker RE, Lomax RG. A beginner's guide to structural equation modeling (3rd ed.). New York, NY US: Routledge/Taylor \& Francis Group; 2010.

86. Houkes I. Work and individual determinants of intrinsic work motivation, emotional exhaustion and turnover intention. A study among bank employees and teachers [PhD thesis]. Maastricht: Maastricht University.; 2002.

87. De Jonge J. Job autonomy, well-being, and health. Maastricht: Maastricht University; 1995.

88. Cortina JM, Chen G, Dunlap WP. Testing Interaction Effects in LISREL: Examination and Illustration of Available Procedures. Organizational Research Methods. 2001 October 1, 2001;4(4):324-60.

89. Bakker AB, Hakanen JJ, Demerouti E, Xanthopoulou D. Job resources boost work engagement, particularly when job demands are high. Journal of Educational Psychology. 2007;99(2):274-84.

90. Demerouti E, Mostert K, Bakker AB. Burnout and work engagement: $A$ thorough investigation of the independency of both constructs. Journal of Occupational Health Psychology. 2010;15(3):209-22.

91. Aiken LS, West SG, Luhmann M, Baraldi A, Coxe SJ. Estimating and graphing interactions. In: Cooper H, Camic PM, Long DL, Panter AT, Rindskopf D, Sher KJ, editors. APA handbook of research methods in psychology, Vol 3: Data analysis and research publication. Washington, DC US: American Psychological Association; 2012. p. 101-29.

92. MacCallum RC, Browne MW, Sugawara HM. Power analysis and determination of sample size for covariance structure modeling. Psychological Methods. 1996;1(2):130-49.

93. De Jonge J, Dormann C. Stressors, resources, and strain at work: a longitudinal test of the triple-match principle. J Appl Psychol. 2006 Nov;91(6):1359-74

94. Havlovic SJ, Lau DC, Pinfield LT. Repercussions of work schedule congruence among full-time, part-time, and contingent nurses. Health Care Manage Rev. 2002 Fall;27(4):30-41.

95. Hobfoll SE. Social and psychological resources and adaptation. Review of General Psychology. 2002;6(4):307-24.

96. Van der Doef M, Maes S. The Job Demand-Control (-Support) Model and psychological well-being: A
97. De Jonge J, Dollard M, Dormann C, Le Blanc P, Houtman I. The Demand-Control Model: Specific Demands, Specific Control, and Well-Defined Groups. International Journal of Stress Management. 2000;7(4).

98. Blair-Loy M. Work Without End?: Scheduling Flexibility and Work-to-Family Conflict Among Stockbrokers. Work and Occupations. 2009;36(4):279-317.

99. Hammer LB, Neal MB, Newsom JT, Brockwood KJ, Colton CL. A longitudinal study of the effects of dual-earner couples' utilization of family-friendly workplace supports on work and family outcomes. J Appl Psychol. [Research Support, Non-U.S. Gov't]. 2005 Jul;90(4):799-810.

100. Taht K, Mills M. Nonstandard Work Schedules, Couple Desynchronization, and Parent-Child Interaction: A Mixed-Methods Analysis. Journal of Family Issues. [Article]. 2012 Aug;33(8):1054-87.

101. Van den Tooren M, de Jonge J, Vlerick P, Daniels K, Van de Ven B. Job Resources and Matching Active Coping Styles as Moderators of the Longitudinal Relation Between Job Demands and Job Strain. Int J Behav Med. 2011 Mar 2.

102. Strijk JE, Proper KI, van Mechelen W, van der Beek AJ. Effectiveness of a worksite lifestyle intervention on vitality, work engagement, productivity, and sick leave: results of a randomized controlled trial. Scandinavian Journal of Work, Environment \& Health. [Research Support, Non-U.S. Gov't]. 2013 Jan;39(1):66-75.

103. Toker S, Biron M. Job burnout and depression: unraveling their temporal relationship and considering the role of physical activity. J Appl Psychol. [Research Support, Non-U.S. Gov't]. 2012 May;97(3):699-710.

104. Friis K, Ekholm O, Hundrup YA. The relationship between lifestyle, working environment, socio-demographic factors and expulsion from the labour market due to disability pension among nurses. Scandinavian Journal of Caring Sciences. 2008;22(2):241-8.

105. Van den Berg TI, Alavinia SM, Bredt FJ, Lindeboom D, Elders LA, Burdorf A. The influence of psychosocial factors at work and life style on health and work ability among professional workers. Int Arch Occup Environ Health. 2008 Aug;81(8):1029-36.

106. Giver H, Faber A, Stroyer J, Hannerz H, Albertsen K. Do lifestyle factors and general health predict dropout among recently qualified eldercare workers? A two-year follow-up study. Scandinavian Journa of Public Health. [Article]. 2011 May;39(3):280-6.

107. Ford MT, Matthews RA, Wooldridge JD, Mishra V, Kakar UM, Strahan SR. How do occupational stressorstrain effects vary with time? A review and meta-analysis of the relevance of time lags in longitudinal studies. Work \& Stress. 2014:28(1):9-30.

108. AZWinfo. Arbeid in Zorg en Welzijn 2010 [Work in Care and Social Welfare]. Zoetermeer: Panteia2011.

109. Podsakoff PM, MacKenzie SB, Lee JY, Podsakoff NP. Common method biases in behavioral research: a critica review of the literature and recommended remedies. J Appl Psychol. [Review]. 2003 Oct;88(5):879-903.

110. Brauchli R, Schaufeli WB, Jenny GJ, Füllemann D, Bauer GF. Disentangling stability and change in job resources, job demands, and employee well-being - A three-wave study on the Job-Demands Resources model. Journal of Vocational Behavior. 2013;83(2):117-29.

111. Schaufeli WB, Maassen GH, Bakker AB, Sixma HJ. Stability and change in burnout: A 10-year followup study among primary care physicians. Journal of Occupational and Organizational Psychology. 2011;84(2):248-67.

112. Nijp HH, Beckers DG, Geurts SA, Tucker P, Kompier MA. Systematic review on the association between employee worktime control and work-non-work balance, health and well-being, and job-related outcomes. Scandinavian Journal of Work, Environment \& Health. [Research Support, Non-U.S. Gov't Review]. 2012 Jul;38(4):299-313. 


\section{ABSTRACT}

Objectives To elucidate the role and pathways of home demands, home and job resources with respect to sickness absence among nurses working in residential elder care.

Methods Longitudinal (SEM)analyses with a one year follow-up among 365 nurses were performed. Analyses were based on survey data and registered sickness absence data. Analyses were controlled for the type of work schedule, working hours, job demands, age, education and gender.

Results More job resources like work schedule fit with private life and more home demands predicted sickness absence one-year later and were mediated through nurses' health rather than nurses' motivation.

Conclusions Adapting the work schedule to the employees' private life and reducing home demands seem a good measure to reduce health-related sickness absence within one year.

\section{SICKNESS ABSENCE OF NURSES WORKING IN RESIDENTIAL ELDER CARE: BOTH JOB- AND HOME-RELATED.}

\section{BACKGROUND}

Sickness absence is an important problem associated with high social and financial costs for employers, employees and their families (1, 2). Especially in residential elder care sickness absence rates are high and higher than in other healthcare professions (3). Sickness absence of nurses is not only a pressing problem for the nurses themselves, it may also lead nursing staff shortages and it decreases the quality of care (4-6). Therefore, a need for preventive measures exists, to reduce sick leave among nurses. However, sickness absence is a multifaceted and rather complex phenomenon (7) and more comprehensive models may support its understanding $(8,9)$.

Most work-stress models (9-11) assume a combination of work-related and personal factors to predict sickness absence. And indeed there is vast evidence that work-related factors predict sickness absence $(9,12-15)$. Although demanding home situations of nurses also can lead to health problems (16-19), the association between the home situation and sickness absence remains unclear.

One reason may be that a possible positive role of work- and home-related resources is not taken into account. In addition, nurses could value the work schedule itself as a resource $(20,21)$. Especially for nurses working in residential elder care with different types of work schedules, this possible resource may be of great value to prevent sickness absence $(16,22)$. Elucidating this will refine theoretical models of nurses with shiftwork. Therefore, main focus in this article will be on home characteristics and job resources to make more progress in this respect.

\section{The Potential of resources}

One of the theories that focus on resources is the Conservation of Resources theory (COR) (23) and has been used to explain sickness absence from a resource perspective (12). It seems a valuable theory to emphasize the benefits of work, not only the effect of demands but also that of resources on sickness absence. According to the COR theory, resources are entities that have intrinsic or instrumental value and can be found in the social contexts, including objects, conditions, personal resources, and energy resources (24). Stress results when they risk or actually do lose these resources, the threat of resource loss, or there is a lack of resource gain after the investment of resources (25). The COR theory assumes that there are two ways nurses could react when they encounter stressors in their environment and how those encounters could influence their well-being. The first assumption of COR theory is a loss spiral; people attempt to obtain, retain, and protect resources and that stress occurs when they risk losing, or actually lose, such resources (25). For example, nurses who experience high levels of stress want to keep or regain their energy by reporting ill. 
The second assumption of COR-theory is a gain spiral: resources can generate new resources. In the absence of stressors, people strive to obtain more resources. This activity creates buffers for more difficult times and increases well-being because additional resources are valued $(16,26)$. Social support at home, assisting with home duties, or advice from their partners may help nurses to overcome work problems and consequently increase motivation and performance at work (27). Those nurses experience more physical and psychological resources allowing them to invest further in resources instead of prevent the loss (27-29). This process could lead to less sickness absence. The relationship of work-related resources and well-being, motivation and sickness absence is already well researched (30). However more research on how home resources determine negative and / or positive work consequences among nurses is needed (30-32).

\section{Home resources}

In line with the second central assumption of the COR theory, it is plausible that the home domain could serve as a resource for nurses. According to this second central assumption that when resources are obtained, they appear to create a gain spiral, in which resources can accumulate (25). Nurses with, for example, a supportive home or more autonomy at home seem better equipped to handle stressful circumstances and avoid problematic situations. They experience more resources, such as physical health and emotional support $(16,26)$. Also being part of a family appeared to play a role in the prevention of the development of health problems among nurses (26). Furthermore, home resources have shown to positively influence performance (27).This could allow nurses to invest further in resources instead of to prevent losing them (27-29).

\section{Job resources}

Job resources are expected to be negatively related to sickness absence via higher motivation or lower health problems $(15,30)$. The focus in this research is on the role of home characteristics with respect to sickness absence, but we include specific work schedule related job resources, e.g. work schedule fit with private life, work schedule control and social support at work (21, 33-35) that have proven to diminish the impact of different work schedules. Although it is not always clear-cut if a work or home-related factor is a demand or a resource (30), in the present research the fit of the work schedule with private life is considered to be a resource. If a factor is a demand or a resource depends on how it is valued by nurses. Work schedules negatively influence health problems, sickness absence and job departure (36-38), but they might also be valued as a resource by nurses working in residential elder care. Work schedules provide opportunities for nurses to combine work and care and to relieve home demands $(20,21)$. In line with the COR-theory, work schedules could be functional in achieving work goals, reduce job demands, or stimulate personal growth and development. Job resources are assumed to predict sickness absence via motivation and health complaints $(12,15,39)$.

\section{Sickness absence}

Sickness absence is defined as absence from work that is attributed to sickness by the employee and accepted as such by the employer (40). Two most common absence measures are absence episodes and duration $(7,41,42)$. As stated, the relationship between home characteristics and sickness absence among nurses seems not straightforward and could be mediated by health and motivational aspects $(9,22)$.

In general, two different pathways are assumed to influence sickness absence episodes and duration $(9,13,43)$. The first pathway is that long-term sickness absence is associated with ill health $(12,13,44)$ and this is framed as 'involuntary absence'. According to the COR-theory, home demands predict health complaints such as burnout, fatigue and psychosomatic health complaints and health complaints subsequently predict sickness absence duration $(9,12,13,45)$.

The second pathway assumes that frequent short-term sickness absence is associated with work environmental factors and work engagement and this is framed as 'voluntary absence' $(12,13,44)$ According to the COR theory, positive job characteristics lead to positive outcomes such as work engagement, job satisfaction (46), and subsequently these factors lead to less sickness absence episodes $(9,12,22)$. Moreover, as mentioned according to the COR theory, home and work-related resources are also negatively related to health complaints. Furthermore, sickness absence duration and frequency seem also to be positively related to each other $(12,39)$.

Studies investigating the effects of home characteristics on health and sickness absence are scarce and according to Ten Brummelhuis et al. (22) show inconsistent findings. One explanation may be that most studies use simple one-dimensional measures to measure home characteristics such as the number of (small) children, hours spent on housekeeping, or having a relationship or not. For example, Allebeck and Mastekaasa (44) found no evidence in their literature review for an association between sickness absence with quantitative measures, such as marital status and (number of) children living at home. This is in line with other research that found that merely the perception of home characteristics was associated with health and well-being $(27,47,48)$. We will use a better measure for home demands. Another explanation for the inconsistent findings could be that the relationship between home characteristics and sickness absence among nurses is mediated by health and motivational aspects $(9,22)$.

In sum, the aim of the present study is to contribute to a better understanding of the influence of home demands, home resources and work schedule related job resources on nurses' sickness absence. Because research has shown that job demands are related to health and motivationa factors $(30,49)$, we consider job demands in the present research as a confounder of the relations under study. 


\section{Hypotheses and research model}

Based on the theoretical and empirical findings, it seems important to use a mediation model in the present research, in order to include nurses' home demands and resources and work schedule related job resources to explore the relationship between the home domain and sickness absence. Furthermore, a longitudinal design is essential to examine how home- and job-related resources are related to sickness absence $(22,37,50)$. Therefore, and incorporated in the research mode (see Fig. 1), it is hypothesized that:

1a. Home demands predict positively sickness absence duration via health complaints,

1b. Home demands predict positively sickness absence episodes via health complaints,

2a. Home resources predict negatively sickness absence duration via both health complaints and motivation,

$2 \mathrm{~b}$. Home resources predict negatively sickness absence episodes via both health complaints and motivation,

3a. Job resources predict negatively sickness absence duration via both health complaints and motivation,

$3 \mathrm{~b}$. Job resources predict negatively sickness absence episodes via both health complaints and motivation.

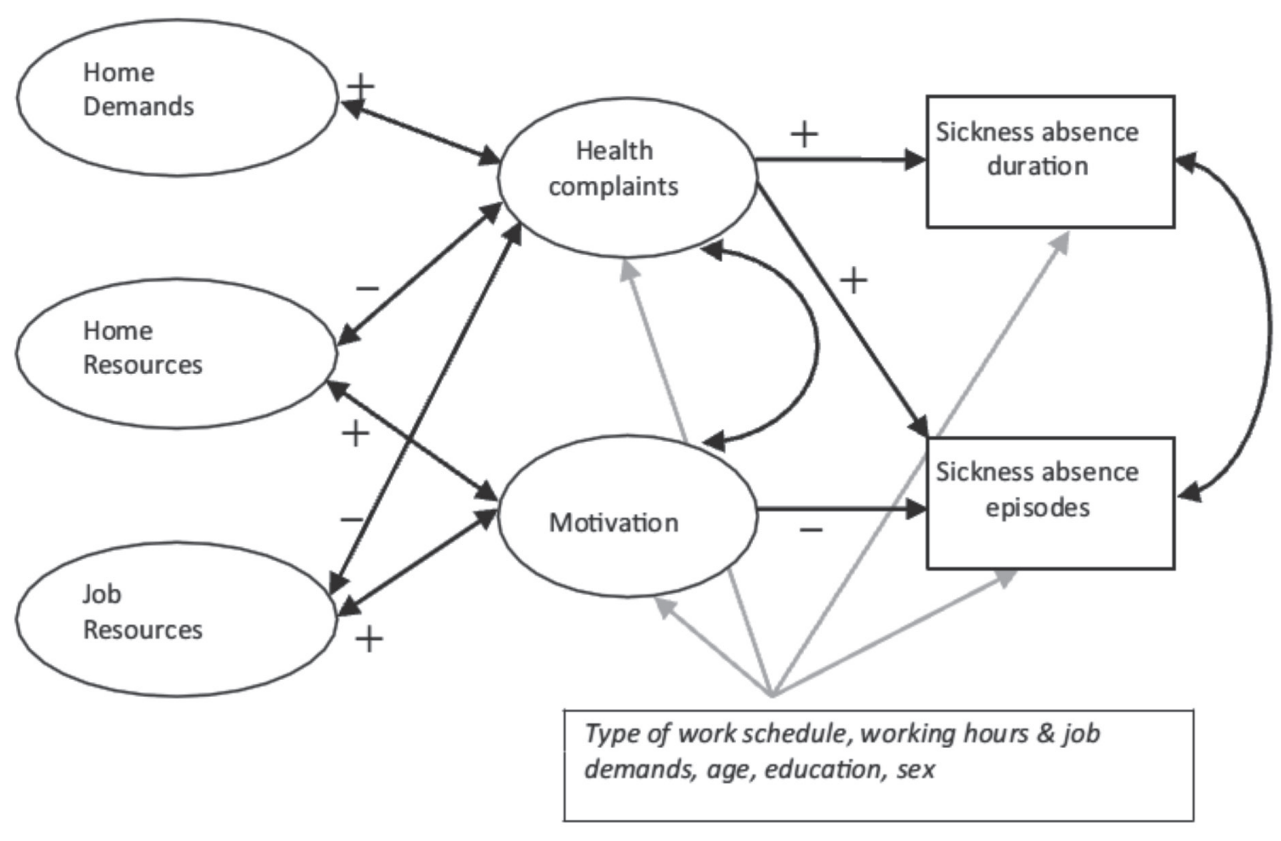

Figure 1: The research model.

\section{METHODS}

\section{Sample and procedure}

In this longitudinal study self-reported questionnaires were used to measure the independent variables. Registered sickness absence data were used to measure the dependent variables. The participants were nurses (48) in residential care for the elderly. The two facilities that participated were included because the nurses' work schedules generally reflected nursing work schedules in the Netherlands and provided sickness absence data. Questionnaires were sent to the home addresses of all nursing employees. The participants were asked to return them within two weeks. Reminders were sent to all participants two and three weeks after the initial distribution of the questionnaires. The assessment of the questionnaire, which measured the independent and mediating variables, was in October 2009. The questionnaires contained a code to identify participants the second time and to match the organization sickness absence records. To measure sickness absence duration and episodes, we used the organizations' absenteeism reports from October 2009 until October 2010 as dependent variables. This period was chosen because it was long enough to measure possible changes in individual scores and also to control for seasonal effects $(51,52)$

\section{Ethical considerations}

The study was not submitted to an ethical committee because, according to Dutch law (Wet Medisch-Wetenschappelijk Onderzoek met Mensen/Medical Research Involving Human Subjects Act), surveys only have to be submitted to an ethical committee in a limited number of situations, which do not apply to the present study. The study was approved by the management board of the homes involved. The participants were informed by individual letter and an institutional newsletter they were free to refuse to participate and welcomed to ask questions and express concerns about the study any time. Return of a completed questionnaire was taken to imply consent. Data were stored anonymously, treated confidentially and the participants' privacy was sufficiently guaranteed.

\section{Sample}

The total study population comprised 911 nurses who worked shifts and were employed in one of the two participating facilities. The mean age of the research population registered by the organization before the assessment of the questionnaire was 39.8 years $(S D \pm 12.3)$, average working week was $21.5 \mathrm{hrs}$ per week $(\mathrm{SD} \pm$ 9.8) and median absence duration was three days per episode and the median episodes was one time per year. Although 'nurse' indicates normally the qualification level of a registered nurse, the current research uses this term for nurses working in residential elder care in the Netherlands. This includes registered nurses, enrolled nurses, licensed vocational or practical nurses and nurse care helpers. In the Netherlands nurses working in residential elder care are comparable with respect of qualification level to Dutch nurses working in hospitals, 
home care, care for disabled people and mental health care but do have different psychosocial and physical demands (Simon et al., 2008). At Time 1, 462 questionnaires (51\%) were included. Only new sickness absence incidents were included. Respondents who left the job, nurses who did not respond, or without sick leave registration were not analysed.

\section{Measures}

Home demands

Home demands were operationalized as three psychosocial home characteristics: 1) emotional home demands, 2) quantitative home demands and 3) cognitive home demands, and measured as follows: Emotional home demands contain four, quantitative home demands five and cognitive home demands four items ; they are scored on a 4-point scale ranging from 0 'never' to 3 'always'. Example items are: "How often do emotional issues arise at home?", "Do you find that you are busy at home?" and "Do you find that you have to plan and organize a lot of things in relation to your home life?" The internal consistency found (Cronbach's alpha) is $0.76,0.80$ and 0.80 respectively (47)

\section{Home resources}

Home resources were measured with three psychosocial home characteristics: 1) home autonomy, 2) social support at home and 3) the possibility to arrange something else. Home autonomy contains four items scored on a 5-point response scale, ranging from 0 'never' to 4 'always'. An example item is: "I have control over how I use my free time' (27). The internal consistency (Cronbach's alpha) is 0.74 . Social support at home (53) contains eight items (measuring social support from one's spouse, relatives and friends) scored on a 5-point response scale ranging from 0 'never' to 4 'always'. An example item is: "To what extent is/are your [spouse/relatives/friends] willing to listen to your problems?" The internal consistency (Cronbach's alpha) is 0.88 and a single-item question. The possibility to arrange someone or something else was measured with a single item: "When something unexpected happens in your home situation, to what extent is it possible for you to arrange things?" This scale uses a 4-point response scale that ranges from 'never' to 'always' (54).

\section{Job resources}

Job resources were measured with three psychosocial job characteristics: 1) work schedule fit with private life, 2) work schedule control and 3) social support at work. Satisfaction with Irregular Working hours (SIW) (16) was used to measure the extent to which the work schedule fits with nurses' private life, particularly in relation to leisure time, family situation, social circumstances, sleep and work-leisure time balance. The scale consists of fourteen items that are scored on a 5 -point response scale ranging from 1 'entirely dissatisfied' to 5 'entirely satisfied', for example:
"How satisfied are you with the quality of your contact with family, friends and spouse given your irregular working hours?". The internal consistency (Cronbach's alpha) was 0.89 (16). Work schedule control (WSC) was measured with a scale that assesses perceptions of having choice and influence over starting and ending times, days off, breaks during the workday, swapping shifts and taking unpaid leave. It consisted of 10 items scored with either 1 ('yes') or 0 ('no'). Example item is: "Can you decide to take a break when you want?" The internal consistency (Cronbach's alpha) was 0.66 (55). Social support refers to the worker's perceived social support from supervisors and colleagues. This was measured using a 10-item scale derived from a Dutch questionnaire for organisational stress (56). This scale uses a 4-point response scale that ranges from 0 'never' to 3 'always' (Item example: "If you have problems at work, can you discuss them with your colleagues?") (Cronbach's a= 0.82).

\section{Health complaints}

Health complaints were measured with three indicators: 1) Emotional exhaustion, 2) General fatigue and 3) Psychosomatic health complaints. Emotional exhaustion was measured using a subscale of the Dutch version of the Maslach Burnout Inventory-General Survey (57). Emotional exhaustion seems the most characteristic burnout dimension in general and in nursing (58-60). The Maslach scale contains five items that are scored on a 7-point response scale ranging from 0 'never' to 6 'always'. An example of the items is "Working all day is really a strain for me". The internal consistency (Cronbach's alpha) is 0.84-0.90. General fatigue was measured with the Multidimensional Fatigue Inventory (MFI) (61). This scale has four items scored on a 5-point scale ranging from 'yes, that is true' to 'no, that is not true'; a higher score indicates more general fatigue. An example item is 'I feel very tired'. The internal consistency (Cronbach's alpha) is 0.84 . Psychosomatic health complaints were measured with a 13-item version of a Dutch perceived health questionnaire (VOEG (Vragenlijst Onderzoek Ervaren Gezondheid [Perceived Health Questionnaire]) developed by Dirken (62). The VOEG contains items that ask if the respondent suffers from a range of psychosomatic complaints, such as headaches and backache. Each item is scored with either 'yes' or 'no'. A higher score reflects the presence of more psychosomatic complaints. An example of the items is "Working all day is really a strain for me". Internal consistency estimated by Cronbach's $a$ is $0.75-0.93$.

\section{Motivation}

Motivation was measured with three indicators: 1) Work Engagement, 2) Job Satisfaction and 3) Turnover intention. Work engagement was used to assess positive consequences. It was measured with the short version of the Utrecht Work Engagement Scale (UWES-9). It measures a positive, work-related state of fulfilment that is characterized by vigour, dedication and absorption. It consists of nine items and has been found to be reliable and valid (63). Participants responded on a seven- 
point Likert scale, ranging from 'never' (0) to 'always and daily' (6), with higher scores indicating greater work engagement. Examples of items are: "At my work I feel bursting with energy" (vigour), "My job inspires me" (dedication) and "Time flies when I am working" (absorption). The internal consistency (Cronbach's alpha) is 0.93 . Job satisfaction was measured using a single item asking "How satisfied are you with your job in general?" scored on a 10-point scale ranging from 1 'very dissatisfied' to 10 'very satisfied'. Turnover intention was measured by means of a 4-item scale originating from the Dutch Quality of Work Questionnaire [Vragenlijst Beleving en Beoordeling van de Arbeid (VBBA)] (64) ranging from 0 'no'- 1 'yes'. An example item is: "I intend to leave this organization this year". The internal consistency (Cronbach's alpha) is 0.90 .

Sickness absence duration and episodes

Sickness absence was assessed using the organizations' absenteeism reports. Pregnancy leave was not categorized as sickness absence. Sickness absence was registered according to the usual procedures in the Netherlands by the organization according to the number in days and duration of absence episodes for each person and was linked to the data from the questionnaire by a code. To measure the sickness absence duration, the total number of sick days that each employee had taken between October 2009 and October 2010 were counted, irrespective of the actual working hours. The sickness absence episodes were assessed as the number of absences between October 2009 to October 2010. Absence due to special leave or vacation is not included in this measure. Because both measures showed a non-normal distribution, log transformations were performed. This resulted in good normal distributions for sickness absence duration (skewness $=.798, \mathrm{SE}=$ .126 ; kurtosis $=-.533, \mathrm{SE}=.252$ ) and sickness absence episodes (skewness $=.339, \mathrm{SE}=.126$ kurtosis $=-1.076, \mathrm{SE}=.252$ ).

\section{Confounders}

The type of work schedule (48) and several work and personal characteristics were taken into account as they may correlate health, motivation and sickness absence duration and episodes (10, $15,30,48,65)$ and therefore confound the relationships under study. The type of work schedule nurses worked was measured by a new developed typology (66) which divides the work schedules into five types: Type 1: fixed early shift; Type 2: rotating two-shift pattern (early and afternoon shifts); Type 3: rotating three-shift pattern (early, afternoon and night shifts); Type 4: fixed and rotating two-shift pattern including night shift; and Type 5: fixed normal day or afternoon shifts. The second work schedule demand was the average number of weekly working hours, which was assessed with the following item: "How many hours are you contractually required to work each week?" The variables were recoded using CATPCA to quantify the type of work schedule and working hours per week with job demands as indicator variables (67). Job demands were measured by three dimensions relevant for nurses working in residential elder care: 1) quantitative, emotional and physical job demands. They were measured with reliable scales originating from the Dutch Quality of Work Questionnaire [Vragenlijst Beleving en Beoordeling van de Arbeid (VBBA)] measuring quantitative job demands, emotional job demands and physical job demands (64). The CATPCA resulted in a five-point scale for the type of work schedule: type $1=.67$, type $2=-.39$, type $3=1.014$, type $4=-.77$, and type $5=-3.06$ indicating that there were differences in line with (68) between the types of work schedules: type 3 schedule was the most demanding work schedule and type 5 schedule the least demanding work schedule. The quantifications of the type of work schedule and weekly working hours, age, education and sex have paths to sickness absence duration and episodes, and to health and motivation.

\section{Analysis}

Structural equation modelling (SEM, IBM SPSS AMOS 20) was used to answer the research questions (69). We used a two-step approach (70) by first testing the fit of the model's measurement components followed by testing the structural model. The measurement model included five latent variables according to the theoretical model: Home demands, Home resources, Job resources, Health and Motivation.

To test the structural model a nested model approach was used. The model for these analyses included three exogenous latent factors: home resources, home demands and job resources and two endogenous latent factors: health and motivation. We compared three models: the hypothesized, parsimonious model in which the home demands predicted sickness absence duration and episodes via health and home resources and job resources predicted sickness absence episodes via motivation (M1) , the M1 model with paths added linking the home and job resources to health (M2) (30) and a model testing partial mediation, similar to $\mathrm{M} 2$ but with direct paths linking home and job resources and home demands to absence duration and episodes. We tested whether a more parsimonious model fit the data just as well as the research model with more parameters by using a chi-square difference test. The endogenous latent job resources were allowed to correlate with the latent factors 'home demands' and 'home resources'.

$\mathrm{Chi}^{2}$, $\mathrm{Chi}^{2}$ difference test, GFI, RMSEA, NFI, and SRMR were assessed. The Chi' ${ }^{2}$, GFI, RMSEA and SRMR were used to examine the fit of the measurement model to the data. Models with RSMEA below .05 in combination with SRMR values below .09 indicate excellent fit, whereas values below .08 and .10 , respectively, are still indicative of a good fit. Models with fit indices of $>.95$ and an RMSEA of $<.06$ indicate a close fit between the model and the data. Fit indices between .90 and .95 represent a reasonable fit (71) although Marsh et al. recommend lower values of cut-off values (72). In addition, the IFI and the PNFI were used as relative fit indices and to penalize models that are less parsimonious. The error terms of the control variables were allowed to correlate based on the modification indices. In the final model, type of work schedule, average working hours per week, age, education and gender in line with Olsen and Dahl (38) were included as control variables. 
To test the significance of the regression weights between the predictors, mediators and sickness absence measures and to test the indirect and total effect bootstrapping was used. Bootstrapping is a statistical resampling method that estimates the parameters of a model and their standard errors strictly from the sample (73) and is especially useful when testing a multiple mediator model. New samples were extracted (with replacement) from the sample 2000 times and calculated all direct and indirect estimates of the hypothesized model. Bootstrapping computes more accurate confidence intervals (Cls) of indirect effects than the more commonly used methods, such as the causal steps strategy (74) and the Sobel test. The null hypothesis, which states that $x$ does not have an indirect effect on y via $\mathrm{m}$, is rejected when the entire $\mathrm{Cl}$ lies above or below zero.

\section{RESULTS}

Before the first assessment on baseline (T0), according to the organizational databases, nurses $(\mathrm{n}=911)$, were 39.8 years old $(S D \pm 12.3$ ) and worked 21.4 hours per week $(S D \pm 9.9)$ on contractual basis. As can be seen in Figure 2, 462 responded (51\%) at the first questionnaire assessment ( $T 1$, October '09). The average age of the respondents (42.2 years; $S D \pm 12.1)$ according to the organizational databases was higher than ( $t$-value $=6.537(889), p<.001)$ the non-respondents (36.9 years; $S D \pm 11.9$ ). The average working hours per week did not differ between the respondents and non-respondents. Of the 462 nurses that responded to the assessment of the questionnaire (T1, October '09), 97 were finally excluded because one year later they quit the job, no sickness absence data were available, or were absent due to long term sickness at baseline.

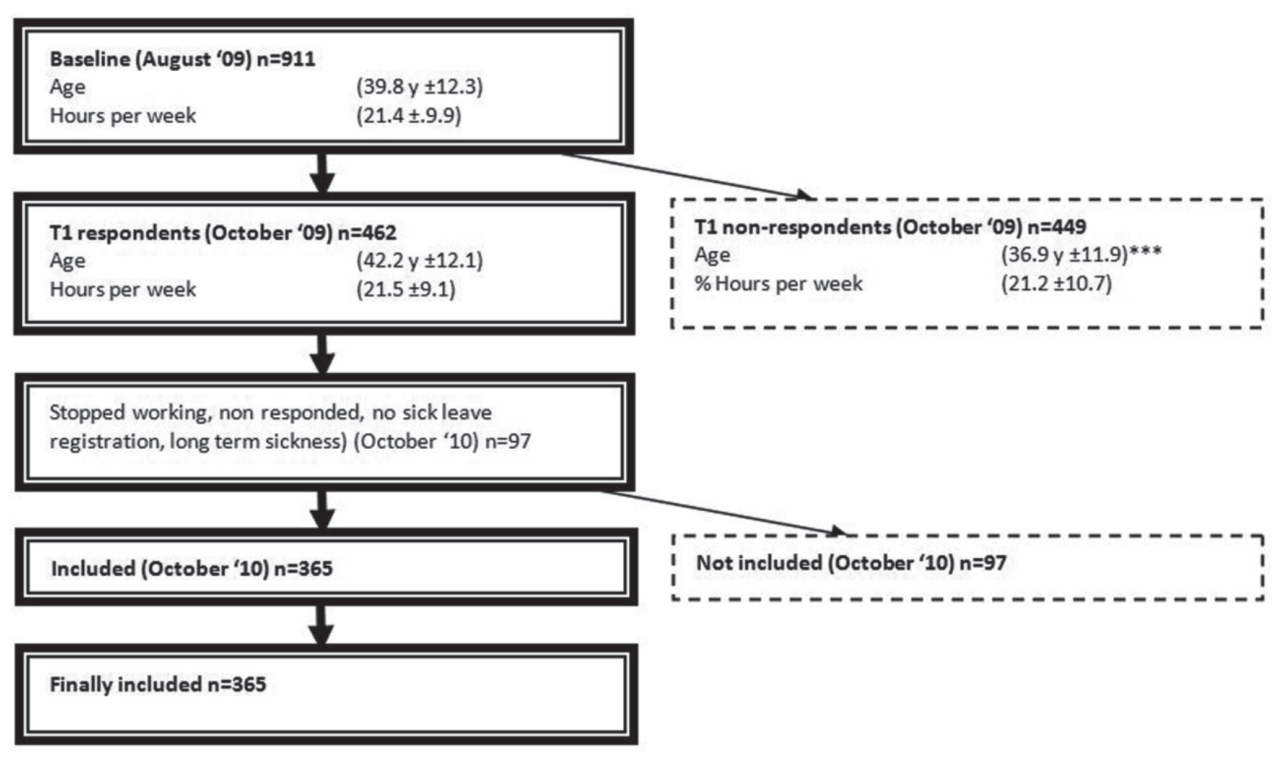

Figure 2: Flowchart of inclusion process an t-tests between nurses that were included and were not included.
The final group ( $n=365$ ) comprised mainly women $(97.6 \%)$, which is normal for residential health care in the Netherlands. The mean age of the respondents was 41.5 years ( $S D=12.1)$. Twenty-two respondents (6\%) had full-time contracts (36 contractual work hours a week). Sixty-seven percent had children living at home and $33.4 \%$ had children below the age of twelve. Correlational analyses showed that these background variables were only marginally related to the model variables (Table 1).

The nurses that finally were included $(n=365)$ were compared to the nurses that were excluded. With respect to the outcome variables, sickness absence duration ( $t$-value $=-1.235(443), p>.05$ ) and episodes ( $t$-value $=-1.714$ (443), $p>.05$ ) of 2009 did not differ between the respondents and non-respondents. When the sickness absence duration and episodes of our sample between 2008 2009 and 2009-2010 were compared, the mean sickness absence duration was similar ( $t$-value $=$ 1.869 (364), $p>.05)$. The number of sickness absence episodes was higher in 2009 compared to 2010 ( $t$-value $=3.667$ (364) $p<.05)$, Cohen's $d=0.211$ which means a small change (75). Gender differed slightly between the respondents and non-respondents with somewhat more males that non-responded; $X^{2}(1)=5.255, p=.022$. Hours worked per week ( $t$-value $\left.=-2.101(456), p<.05\right)$ was higher among the respondents with a Cohen's $d=0.244$ which means again a small difference (75).

\section{Descriptive statistics}

Table 1 shows the descriptive statistics for each variable measured in the study, the correlation coefficients and the internal consistency of the scale measures.

\section{Results of Structural Equation Modelling}

The measurement model showed a reasonable fit to the data $\left(X^{2}(80)=209.17(p<.001), C F I\right.$ $=.92, \mathrm{GFI}=.93, \mathrm{TLI}=.89, \mathrm{RMSEA}=0.067$ ), with all significant loadings on the intended factors ranging from .38 to .85 . To test the validity of the measurement model with five factors, we compared it with an one factor model. The fit of the five factor measurement model was better than the fit of a one factor model $\left(\mathrm{X}^{2}(90)=741.0(\mathrm{p}<.001), \mathrm{CFI}=.57, \mathrm{GFI}=.76, \mathrm{TLI}=.50, \mathrm{RMSEA}=0.141\right)$. 
We compared the model fit with a more parsimonious model with separate pathways and no paths from home and job resources to health complaints (M1) and with a partial mediation model (M3) which included direct effect. Table 2 shows the results of the nested models analyses. Three nested models were compared by means of the Chi-square difference test.

Table 2: Results of Structural Equation Modeling

\begin{tabular}{llllllllllll}
\hline \multicolumn{1}{c}{ Model } & $\boldsymbol{X}^{\mathbf{2}}$ & $\mathbf{d f}$ & RMSEA & $\mathbf{9 0} \% \mathbf{C l}$ & SRMR & GFI & AGFI & IFI & PNFI & $\left.\boldsymbol{\Delta X}^{2} \mathbf{( d f}\right)$ & $\boldsymbol{p}$ \\
\hline Saturated model & .000 & 0 & & & & 1.000 & & 1.000 & .000 & & \\
M1 Parsimonious model & 418.8 & 171 & .063 & $.055-.071$ & .0683 & .907 & .868 & .885 & .607 & & \\
M2 Resources to Health & 383.7 & 169 & .059 & $.051-.067$ & .0584 & .914 & .871 & .901 & .611 & $35.17(2)$ & $<.001$ \\
Complaints & & & & & & & & & & & \\
M3 Partial mediation & 376.0 & 163 & .060 & $.052-.068$ & .0580 & .915 & .862 & .902 & .592 & $7.64(6)$ & $=.266$ \\
Independent? model & 2331.6 & 231 & .158 & $.152-.164$ & .000 & .545 & .502 & .000 & .000 & & \\
\hline
\end{tabular}

The results of these analyses show that the M1 model fitted reasonable good to the data (see Table 2), but that linking job and home resources to the latent variable 'health complaints' improved the Chi-square significantly (M2). Adding direct relationships from the latent exogenous variables home demands, home resources and job resources to the sickness absence measures (M3) did not significantly improve the chi-square. In addition, the RMSEA was the lowest and (.059) under the threshold for M2, SRMR was sufficient in combination with the RMSEA. The PNFI was the highest for the M2 model compared to both other models. Therefore, M2, linking home and job resources to health complaints was considered the best-fitted and most parsimonious model.

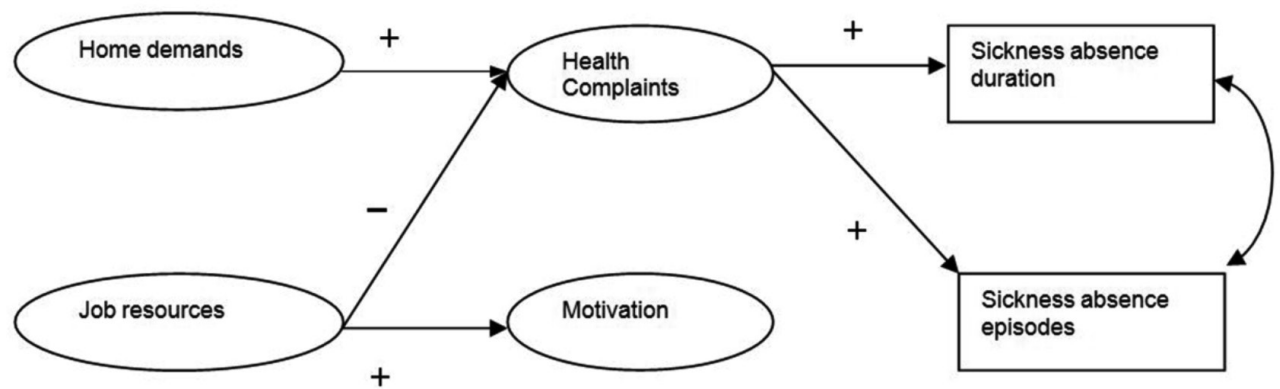

Figure 3: The final model (controlled for the type of work schedule, average number of weekly working hours, gender, age and education).

The pathway estimates of the final structural model are shown in Figure 3. Home demands were positively related to health complaints $(\beta=.62 ; \mathrm{LCl}-\mathrm{UCl}=.25-1.05 ; p=.005)$. Job resources $(\beta=2.22 ; \mathrm{LCl}-\mathrm{UCl}=1.57-3.64 ; p=.001)$ were positively related to motivation. Job resources were negatively related to health complaints $(\beta=-1.50 ; \mathrm{LCl}-\mathrm{UCl}=-2.95--.71 ; p=.001)$. Health 
complaints was positively related to sickness absence duration $(\beta=.19 ; \mathrm{LCl}-\mathrm{UCl}=.09-.29 ; p=$ .001) and sickness absence episodes ( $\beta=.06 ; \mathrm{LCl}-\mathrm{UCl}=.02-.09 ; p=.002)$. The model explained $9 \%$ of the variance in sickness absence duration and $8 \%$ of the variance in absence frequency.

The results of the indirect and total effects bootstrap results are shown in Table 3.

Table 3: Bootstrapping results of indirect and total effects of home demands and home and job on sickness absence duration and episodes through health (m1) and motivation (m2)

\begin{tabular}{|c|c|c|c|c|c|}
\hline \multirow{3}{*}{$\mathbf{x} \rightarrow \mathbf{m} 1 \rightarrow \mathbf{y}$} & \multicolumn{2}{|c|}{ Bootstrapping } & \multicolumn{3}{|c|}{ BC $95 \% \mathrm{Cl}$} \\
\hline & Coeff & SE & Lower & Upper & \\
\hline & & & Cl & Cl & \\
\hline $\mathrm{HD} \rightarrow$ health complaints $\rightarrow$ Sickness absence duration & 116 & .058 & .034 & .264 & .003 \\
\hline HD $\rightarrow$ health complaints $\rightarrow$ Sickness absence episodes & .034 & .018 & .009 & .084 & .004 \\
\hline $\mathrm{HR} \rightarrow$ health complaints $\rightarrow$ Sickness absence duration & .017 & .080 & -.067 & 214 & .665 \\
\hline $\mathrm{HR} \rightarrow$ health complaints $\rightarrow$ Sickness absence episodes & .000 & .016 & -.027 & .039 & .986 \\
\hline $\mathrm{JR} \rightarrow$ health complaints $\rightarrow$ Sickness absence duration & -.282 & .148 & -.635 & -.097 & .001 \\
\hline$J R \rightarrow$ health complaints $\rightarrow$ Sickness absence episodes & -.085 & .045 & -.204 & -.022 & .001 \\
\hline $\mathbf{x} \rightarrow \mathbf{m} \mathbf{2} \rightarrow \mathbf{y}$ & & & & & \\
\hline $\mathrm{HR} \rightarrow$ motivation $\rightarrow$ Sickness absence episodes & .004 & .011 & -.003 & .056 & 199 \\
\hline$J R \rightarrow$ motivation $\rightarrow$ Sickness absence episodes & -.050 & .042 & -.148 & .021 & .139 \\
\hline $\mathbf{x} \rightarrow \mathbf{m} 1, \mathbf{m} 2 \rightarrow \mathbf{y}$ & & & & & \\
\hline $\begin{array}{l}H R \rightarrow \text { health complaints, motivation } \rightarrow \text { Sickness absence } \\
\text { episodes }\end{array}$ & .007 & .027 & -.020 & .082 & .562 \\
\hline $\begin{array}{l}J R \rightarrow \text { health complaints, motivation } \rightarrow \text { Sickness absence } \\
\text { episodes }\end{array}$ & -.108 & .062 & -256 & -.017 & .024 \\
\hline Total effects & & & & & \\
\hline HD $\rightarrow$ Sickness absence duration & 116 & .058 & .034 & .264 & .003 \\
\hline $\mathrm{HD} \rightarrow$ Sickness absence episodes & .034 & .018 & .009 & .084 & .004 \\
\hline $\mathrm{HR} \rightarrow$ Sickness absence duration & .017 & .080 & -.067 & 214 & .665 \\
\hline $\mathrm{HR} \rightarrow$ Sickness absence episodes & .007 & .027 & -.020 & .082 & .562 \\
\hline$J R \rightarrow$ Sickness absence duration & -.282 & 148 & -.635 & -.097 & .001 \\
\hline$J R \rightarrow$ Sickness absence episodes & -.108 & .062 & -.256 & -.017 & .024 \\
\hline
\end{tabular}

$J R \rightarrow$ Sickness absence episodes

Coeff $=$ unstandardized coefficient; $\mathrm{SE}=$ bootstrap estimate of the standard error; $\mathrm{BC}=$ two-sided biascorrected bootstrap confidence interval for the indirect effect; $\mathrm{LLCl}=$ lower endpoint of a two-sided biascorrected bootstrap confidence interval; $\mathrm{ULCl}=$ upper endpoint of a two-sided bias-corrected bootstrap confidence interval

The results indicated that the indirect relationships between home demands and sickness absence duration and sickness absence episodes were significant. The total effects analysis confirmed these findings. The results indicated that the indirect relationships between job resources and sickness absence duration and sickness absence episodes were significant. The indirect effect on sickness absence episodes via motivation was not significant. The total effects analysis confirmed these findings.

\section{DISCUSSION AND CONCLUSION}

The aim of the current study among nurses working in residential elder care was to gain insight in the role of home demands, home and job resources with respect to sickness absence duration and episodes, and whether these relationships are mediated by health complaints and motivation with the COR-theory as a framework.

Using absence data collected during the year following the assessment of home demands, home resources and job resources, and controlled for the type of work schedule, working hours, age, education and sex, our study supported hypotheses $1 \mathrm{a}, 1 \mathrm{~b}$ and merely supported $3 \mathrm{a}$ and $3 \mathrm{~b}$. Home demands (in this research emotional, quantitative and cognitive home demands) and job resources (in this research the work schedule fit with private life, work schedule control and social support from colleagues and supervisors) are predictive for sickness absence duration and episodes via health complaints but not via motivation. Job resources are positively related to motivation The findings are in support of the health related theories rather than in support of the motivational theories for sickness absence (9).

With respect to hypotheses $1 \mathrm{a}$ and $1 \mathrm{~b}$, home demands have an indirect adverse effect on both sickness absence duration and episodes of nurses via health complaints. Nurses with more home demands have more health complaints, which in turn results in longer sickness absence duration and more sickness episodes. These findings agree with some previous research $(17,22)$, which showed among mainly white collar workers that home demands lead to sickness absence duration and to absence episodes. Our research shows that these relationships are also applicable to a nursing population working in residential care. This is most probably explained by the fact that women are still more responsible for household and childcare than men are $(76,77)$. Especially nurses with extensive family responsibilities focus more on that, than on their own health and well-being (78). An overload of home demands reduces nurses' time to recover from work and could consume their physical and psychological resources $(29,79,80)$. This idea is supported by the COR theory that stress and health problems occur when nurses risk losing, or actually lose resources in their home domain consequently leading to sickness absence (25). Thus, health problems caused by home demands are predictive for 'involuntary' absenteeism which is in line with health related theories to explain sickness absence (9) and the conflict approach that describes depleting processes between the home domain and work outcomes (81)

Hypothesis $3 a$, concerning the indirect effect of job resources, was partially confirmed. Job resources, in this research the work schedule fit with private life, work schedule control and socia support from colleagues and supervisors, had an indirect protective effect on sickness absence duration and sickness absence episodes of nurses via health but not motivation. Nurses' job resources show less health complaints, which in turn resulted in lower sickness absence duration and less sickness absence episodes. According to the COR theory (25), nurses who experience more job 
resources, are more able to gain resources and are better able to preserve health in demanding situations and consequently prevent prolonged absence from work. Lack of job resources, such as low work schedule fit with private life, low control over work schedules and less social support of colleagues and supervisors seem especially harmful for a mainly female working population working in emotional demanding jobs $(16,82-84)$. The findings imply that, although it is found that the home situation for nurses working in residential elder care facilitate recovery from work (26, 79), arrangements at the job seems an essential resource to counterbalance the demands at home.

In contrast with research among managers and executives of a telecom company (12) and employees of a nutrition production company (39), in the present study sickness absence episodes were not related to motivational factors. It seems to imply that findings among other employees are not transferable to the nursing population. This could be due to the fact that nurses can generally be characterized as a highly engaged working population $(32,85)$. Additional analysis showed indeed that the nurses in our research were significantly more work engaged than reference scores accompanying the UWES manual (86)( $t=14.864$ (373); $p<.001)$ and compared to a group of American nurses (87) $(t=3,952$ (373); $p<.001)$. Furthermore, they were significantly more satisfied with their job ( $t=11.863$ (373); $p<.001)$ (88).

Home resources (in the present study autonomy at home, social support at home and the possibility to arrange someone else when needed), were neither related to health or motivation nor related to sickness absence duration or episodes via health or motivation. An explanation is that due to shiftwork, nurses' social life is disrupted which restrains them from psychological resources such as emotional support from family or friends, information or advice $(79,89-91)$. Another explanation can be that home resources, in contrast with home demands, have merely an effect on family-related variables, which were not included in the present research. For example Hakanen et al. (92) found effects of home resources on home- or family-related outcomes.

The lack of an effect of motivation on sickness absence episodes could be explained by Dutch female employees, including nurses mostly working part-time, which differs from other European countries (93). The nurses in our study might have had their voluntary 'sick days' on their days-off, but we did not find empirical evidence for this. Moreover, shiftwork problems are looked upon by nurses as a self-evident consequence of shiftwork and not as reasons for sick leave (94).

\section{Methodological reflection}

The strengths of this study are its longitudinal design using registered sickness absence data of the following year, the extensive questionnaire based on our research model includes well-known and validated instruments, which also made it possible to consider potential confounding factors, such as work schedule related demands and socio-demographic factors.

To test the robustness of our research model, an alternative model wast tested whereby the type of work schedule was fitted into the model as an exogenous variable besides the other exogenous variables home demands, home resources and job resources. This resulted in the same significant direct and indirect effects. Therefore, the robustness of our research model seems sufficient. Furthermore, the choice between our research model and the alternative was made because the $\mathrm{Chi}^{2}$ difference test showed a worsened fit in the alternative model $\left(\Delta \mathrm{Chi}^{2}(d f)=64.1(11) ; p<.001\right)$. This was also confirmed by a higher RMSEA (.064) and lower GFI (.90). Also, the alternative model explained a lower amount of variance in sickness absence duration and episodes.

Although sickness absence was not verified by a company doctor, the sickness absence data gathered from company records are preferable above sickness absence measured by self-reported questionnaires (95) which are prone to recall bias. Moreover, the assessment of the questionnaires was at the start of the research one year before the assessment of the sickness records. A one year time lag was chosen in order to cancel out seasonal fluctuations in registered sickness absence (51). The variance in absenteeism that was explained by health is also higher than in other studies $(12,39) ; 9 \%$ of sickness absence duration and $8 \%$ of sickness absence episodes.

Furthermore, there is positive evidence regarding representativeness. The respondents' age, sex, average weekly working hours and number of years in their current jobs were comparable to those of nurses working in comparable facilities in the Netherlands (3). However, the prevalence of part-time work of other European countries, varies with the Netherlands as a leading country in part-time working (93). Extrapolations of our findings to European countries other than the Netherlands have to be made with care.

The present study has also some other limitations. The variables under examination slightly differ between the respondents and non-respondents; the nurses that are included experienced lower work schedule control than the nurses that are not included implying a small effect $(d=.358$ ) (75). Nurses included in this study show a small decrease of sickness absence episodes compared to the year before the assessments of the questionnaires. Because of this small effect and because the other variables under study did not differ between the responders and non-responders, it can thus be concluded that selective dropout is not a serious problem in the present study.

Finally, the measurement of the demands, resources, health and motivation is based on selfreports, which could lead to inflated associations due to common method variance. However the bivariate correlations are not unusually high, different scale ranges were used and Harman's single factor test did not explain a large portion of variance (29\%). Although the model is based on theoretical and empirical grounds, reciprocal relationships could exist (51). For example, nurses with health complaints or motivational problems could change to a less demanding work schedule $(96,97)$. Consequently, the nurses that are not included possibly could have quit the job or nursing. This could have led to an underestimation of the associations between the home demands, home and job resources and health. 


\section{Conclusion and implications}

This study contributes to the existing knowledge on pathways from the home and job situation to sickness absence duration and episodes. It shows that home demands enhance sickness absence duration and episodes via health complaints and not via a motivational pathway. It also shows that job resources prevent sickness absence via health complaints and not via a motivational pathway. Furthermore, it shows that more job resources enhance motivation.

The present findings have implications for future research and practice. Although determinants could be differently valued, based on the COR-theory, the present research shows that the type of work schedule and its fit with private life is valued as a resource by nurses working in elder care. To further elucidate what the demands and resources are for specific working populations $(9,30)$, the ICF-framework could be helpful. This framework categorizes participation, health and health status of employees and the factors that impact these without valuing determinants on beforehand as a resource or demand $(8,98)$.

Future research could explore the research model with at least a three wave design making it possible to confirm the causal relationships found in the present study between the home demands and job resources and to test for reciprocal relationships. Furthermore, it would be interesting to test if resources are only effective within their domain and demands have detrimental effects on both work and home-related outcomes for nurses working in elder care. Our findings have also implications for more specific research model such as the model used for the standard shiftwork index. Those models focus on demands and detrimental effects of shiftwork. Our findings emphasize the importance of including work schedule related job resources and home demands in future shiftwork models. Therefore, it is important to validate our findings to other professions with shiftwork.

Now we know more about the origin of sickness absence it is possible to pinpoint future interventions that should be tested to prevent sickness absence duration and episodes among nurses working in elder care. To decrease home demands, supervisors should consider their employees' situation at home when supporting them. For example Odle-Dusseau et al. (99) showed that family oriented supervisor increased performance and job-related attitudes among health care workers. Furthermore, nurse supervisors should pay attention besides home demands, to job resources to protect for sickness absence. One way to do so is to use the SIW-questionnaire for measuring the experienced fit between the nurses' work schedule and their private life as a tool to assist them to enhance work schedule fit on a tailor-made basis. Finally, workplace interventions should periodically monitor health of nurses working in elder care more than once a year regarding the dropout in the present study. This is not only interesting for residential elder care, but also for other female professions, which have to fit their varying work schedule with their private life.

\section{REFERENCES}

1. van Amelsvoort LG, Jansen NW, Kant I. Addressing long-term sickness absence: moving beyond disease illness and work-related factors for effective prevention. Scandinavian Journal of Work, Environment \& Health. [Editorial]. 2017 Jan 01;43(1):1-4.

2. Cooper C, Dewe P. Well-being--absenteeism, presenteeism, costs and challenges. Occupational Medicine. [Editorial]. 2008 Dec;58(8):522-4.

3. Onderzoeksprogramma arbeidsmarkt zorg en welzijn [Research Programm Work in Care and Socia Welfare] [database on the Internet]. KIwa Caop. 2015. Available from: http://www.azwinfo.nl/.

4. Trinkoff AM, Johantgen M, Storr CL, Gurses AP, Liang Y, Han K. Nurses' work schedule characteristics, nurse staffing, and patient mortality. Nursing Research. [Research Support, Non-U.S. Gov't]. 2011 JanFeb;60(1):1-8.

5. Halbesleben JR, Rathert C. Linking physician burnout and patient outcomes: exploring the dyadic relationship between physicians and patients. Health Care Manage Rev. 2008 Jan-Mar;33(1):29-39.

6. Kane RL, Shamliyan TA, Mueller C, Duval S, Wilt TJ. The association of registered nurse staffing levels and patient outcomes: systematic review and meta-analysis. Med Care. 2007 Dec;45(12):1195-204.

7. Davey MM, Cummings G, Newburn-Cook CV, Lo EA. Predictors of nurse absenteeism in hospitals: a systematic review. Journal of Nursing Management. [Review]. 2009 Apr;17(3):312-30.

8. Heerkens YF, Engels J, Kuiper C, Van der Gulden J, Oostendorp R. The use of the ICF to describe work related factors influencing the health of employees. Disabil Rehabil. 2004 Sep 2;26(17):1060-6.

9. De Rijk AE. Work Disability Theories: A Taxonomy for Researchers. In: Loisel P, Anema H, editors. Handbook of Work Disability: Springer Verlag; 2013.

10. Härmä M. Workhours in relation to work stress, recovery and health. Scandinavian Journal of Work, Environment \& Health. 2006 Dec;32(6):502-14.

11. De Jonge J, Le Blanc $P$, Schaufeli WB. Theoretische modellen over werkstress [Theoretical job stress models]. In: Schaufeli W, Bakker A, editors. De psychologie van arbeid en gezondheid. Houten: Bohn Stafleu van Loghum; 2013. p. 23-46.

12. Schaufeli WB, Bakker AB, Van Rhenen W. How changes in job demands and resources predict burnout, work engagement, and sickness absenteeism. Journal of Organizational Behavior. 2009:30(7):893-917.

13. Beemsterboer W, Stewart R, Groothoff J, Nijhuis F. A literature review on sick leave determinants (19842004). Int J Occup Med Environ Health. 2009;22(2):169-79.

14. Clausen T, Nielsen K, Carneiro IG, Borg V. Job demands, job resources and long-term sickness absence in the Danish eldercare services: a prospective analysis of register-based outcomes. Journal of Advanced Nursing. [Research Support, Non-U.S. Gov't]. 2012 Jan;68(1):127-36.

15. Roelen CA, van Rhenen W, Schaufeli W, van der Klink J, Mageroy N, Moen B, et al. Mental and physical health-related functioning mediates between psychological job demands and sickness absence among nurses. Journal of Advanced Nursing. [Research Support, N.I.H., Extramural, Research Support, Non-U.S. Gov't, Validation Studies]. 2014 Aug;70(8):1780-92.

16. Peters V, De Rijk AE, Boumans NP. Nurses' satisfaction with shiftwork and associations with work, home and health characteristics: a survey in the Netherlands. J Adv Nurs. 2009 Dec;65(12):2689-700. 
17. Voss M, Floderus B, Diderichsen F. How Do Job Characteristics, Family Situation, Domestic Work, and Lifestyle Factors Relate to Sickness Absence? A Study Based on Sweden Post. Journal of Occupationa and Environmental Medicine. 2004;46(11):1134-43.

18. Demir A, Ulusoy M, Ulusoy MF. Investigation of factors influencing burnout levels in the professional and private lives of nurses. International Journal of Nursing Studies. 2003;40(8):807-27.

19. Boumans NP, Dorant E. Double-duty caregivers: healthcare professionals juggling employment and informal caregiving. A survey on personal health and work experiences. Journal of Advanced Nursing [Research Support, Non-U.S. Gov't]. 2014 Jul;70(7):1604-15.

20. Ruggiero JS, Pezzino JM. Nurses' perceptions of the advantages and disadvantages of their shift and work schedules. The Journal of nursing administration. 2006 Oct;36(10):450-3.

21. Peters V, Houkes I, De Rijk AE, Bohle PL, Engels JA, Nijhuis FJN. Which resources moderate the effects of demanding work schedules on nurses working in residential elder care? A longitudinal study. International Journal of Nursing Studies. 2016;58:31-46.

22. Ten Brummelhuis $\mathrm{LL}$, ter Hoeven $\mathrm{CL}$, de Jong MDT, Peper B. Exploring the linkage between the home domain and absence from work: Health, motivation, or both? Journal of Organizational Behavior. 2013;34(3):273-90.

23. Hobfoll SE, Johnson RJ, Ennis N, Jackson AP. Resource loss, resource gain, and emotional outcomes among inner city women. Journal of Personality and Social Psychology. 2003;84(3):632-43.

24. Gorgievski MJ, Hobfoll SE. Work can burn us out and fire us up; Conservation of Resources in Burnout and Engagement. In: Halbesleben JRB, editor. Handbook of stress and burnout in health care. Hauppage, new York: Nova Publishers; 2008. p. pp. 7-22.

25. Hobfoll SE. Social and psychological resources and adaptation. Review of General Psychology. 2002;6(4):307-24

26. Winwood PC, Winefield AH, Lushington K. Work-related fatigue and recovery: the contribution of age domestic responsibilities and shiftwork. Journal of Advanced Nursing. 2006;56(4):438-49.

27. Demerouti $E, B a k k e r A B$, Voydanoff $P$. Does home life interfere with or facilitate job performance? European Journal of Work and Organizational Psychology. 2010;19(2):128-49.

28. Greenhaus JH, Powell GN. When Work and Family Are Allies: A Theory of Work-Family Enrichment The Academy of Management Review. 2006;31(1):72-92.

29. Ten Brummelhuis $L L$, Bakker AB. A resource perspective on the work-home interface: the work-home resources model. Am Psychol. 2012 0ct;67(7):545-56.

30. Schaufeli WB, Taris TW. A Critical Review of the Job Demands-Resources Model: Implications for Improving Work and Health. 2014:43-68.

31. Caruso CC, Bushnell T, Eggerth D, Heitmann A, Kojola B, Newman K, et al. Long working hours, safety, and health: toward a National Research Agenda. Am J Ind Med. 2006 Nov;49(11):930-42.

32. Simpson MR. Engagement at work: a review of the literature. Int J Nurs Stud. 2009 Jul;46(7):1012-24

33. Nijp HH, Beckers DG, Geurts SA, Tucker P, Kompier MA. Systematic review on the association between employee worktime control and work-non-work balance, health and well-being, and job-related outcomes. Scandinavian Journal of Work, Environment \& Health. [Research Support, Non-U.S. Gov't Review]. 2012 Jul;38(4):299-313.

34. Ala-Mursula, Vahtera J, Linna A, Pentti J, Kivimäki M. Employee worktime control moderates the effects of job strain and effort-reward imbalance on sickness absence: the 10-town study. Journal of Epidemiology and Community Health. 2005 October 2005;59(10):851-7.
35. Schmieder RA, Smith CS. Moderating effects of social support in shiftworking and non-shiftworking nurses. Work \& Stress. 1996 1996/04/01;10(2):128-40.

36. Demerouti E, Geurts SA, Bakker AB, Euwema M. The impact of shiftwork on work--home conflict, job attitudes and health. Ergonomics. $2004 \mathrm{Jul}$ 15;47(9):987-1002.

37. Merkus SL, van Drongelen A, Holte KA, Labriola M, Lund T, van Mechelen W, et al. The association between shift work and sick leave: a systematic review. Occupational and Environmental Medicine. [Research Support, Non-U.S. Gov't Review]. 2012 0ct;69(10):701-12.

38. Olsen KM, Dahl S-Å. Working time: implications for sickness absence and the work-family balance. International Journal of Social Welfare. 2010;19(1):45-53.

39. Bakker AB, Demerouti $E$, de Boer $E$, Schaufeli WB. Job demands and job resources as predictors of absence duration and frequency. Journal of Vocational Behavior. 2003;62(2):341-56.

40. Whitaker SC. The management of sickness absence. Occupational and Environmental Medicine 2001;58 (6):420-4.

41. Hensing G. Swedish Council on Technology Assessment in Health Care (SBU). Chapter 4. Methodological aspects in sickness-absence research. Scand J Public Health Suppl. 2004;63:44-8.

42. Hensing G. The measurements of sickness absence - a theoretical perspective. Norsk Epidemiologi ; (2): . 2009;19(2):147-51

43. Stapelfeldt CM, Jensen C, Andersen NT, Fleten N, Nielsen CV. Validation of sick leave measures: selfreported sick leave and sickness benefit data from a Danish national register compared to multiple workplace-registered sick leave spells in a Danish municipality. BMC Public Health. 2012;12:661-72.

44. Allebeck P, Mastekaasa A. Swedish Council on Technology Assessment in Health Care (SBU). Chapter 5. Risk factors for sick leave - general studies. Scand J Public Health Suppl. [Review]. 2004;63:49-108.

45. Duijts SF, Kant I, Swaen GM, van den Brandt PA, Zeegers MP. A meta-analysis of observational studies identifies predictors of sickness absence. J Clin Epidemiol. 2007 Nov;60(11):1105-15.

46. van der Giezen AM, Bouter LM, Nijhuis FJN. Prediction of return-to-work of low back pain patients sicklisted for 3-4 months. Pain. 2000;87(3):285-94.

47. Peeters MCW, Montgomery AJ, Bakker AB, Schaufeli WB. Balancing Work and Home: How Job and Home Demands Are Related to Burnout. International Journal of Stress Management. 2005;12(1):43-61.

48. Peters V, Engels JA, De Rijk AE, Nijhuis FJ. Sustainable employability in shiftwork: related to types of work schedule rather than age. Int Arch Occup Environ Health. 2015 Jan 13.

49. Bakker AB, Demerouti E. The Job Demands-Resources model: State of the art. Journal of Managerial Psychology. 2007;22(3):309-28.

50. Beauregard N, Marchand A, Blanc ME. What do we know about the non-work determinants of workers mental health? A systematic review of longitudinal studies. BMC Public Health. [Research Support Non-U.S. Gov'tReview]. 2011;11:439

51. De Lange AH, Taris TW, Kompier MAJ, Houtman ILD, Bongers PM. The relationships between work characteristics and mental health: examining normal, reversed and reciprocal relationships in a 4-wave study. Work \& Stress. 2004 2004/04/01;18(2):149-66.

52. Zapf D, Dormann C, Frese M. Longitudinal studies in organizational stress research: A review of the literature with reference to methodological issues. Journal of Occupational Health Psychology. 1996;1(2):145-69.

53. Van Daalen G, Willemsen TM, Sanders K. Reducing work-family conflict through different sources of social support. Journal of Vocational Behavior. 2006;69(3):462-76. 
54. Geurts SAE, Taris TW, Kompier MAJ, Dikkers JSE, Van Hooff MLM, Kinnunen UM. Work-home interaction from a work psychological perspective: Development and validation of a new questionnaire, the SWING. Work \& Stress, October-December 2005;. 2005;19(4):319-39.

55. Peters V, de Rijk AE, Engels J, Heerkens Y, Nijhuis FJN. A new typology of work schedules: evidence from a cross-sectional study among nurses. Work: A Journal of Prevention, Assessment \& Rehabilitation. accepted

56. Bergers GPA, Marcelissen FHG, De Wolff CJ. Handleiding Vragenlijst Organisatiestress-Doetinchem (VOS-D). Nijmegen: Katholieke Universiteit Nijmegen1986.

57. Schaufeli WB, Van Dierendonck D. Handleiding van de Utrechtse Burnout Schaal (UBOS). Lisse: Swets Test Services; 2000.

58. Goodman EA, Boss RW. The phase model of burnout and employee turnover. Journal of Health \& Human Services Administration. [Article]. 2002 Summer/Fall2002;25(1/2):33-47.

59. Tourigny L, Baba VV, Han J, Wang X. Emotional exhaustion and job performance: the mediating role of organizational commitment. The International Journal of Human Resource Management. 2013;24(3):514-32.

60. Wright TA, Cropanzano R. Emotional exhaustion as a predictor of job performance and voluntary turnover Journal of Applied Psychology. 1998;83(3):486-93.

61. Smets EMA, Garssen B, Bonke B, De Haes JCJM. The multidimensional Fatigue Inventory (MFI) psychometric qualities of an instrument to assess fatique. Journal of Psychosomatic Research. 1995;39(3):315-25

62. Dirken JM. Arbeid en stress [work and stress]. Groningen: Wolters Noordhof; 1969.

63. Schaufeli WB, Bakker AB, Salanova M. The Measurement of Work Engagement With a Short Questionnaire. Educational and Psychological Measurement. 2006 August 1, 2006;66(4):701-16.

64. Van Veldhoven M, Meijman T. Het meten van psychosiale arbeidsbelasting met een vragenlijst: de Vragenlijst Beleving en Beoordeling van de Arbeid (VBBA). Amsterdam: NIA; 1994.

65. Michie $S$, Williams $S$. Reducing work related psychological ill health and sickness absence: a systematic literature review. Occupational and Environmental Medicine. 2003;60(1):3-9.

66. Peters V, De Rijk AE, Engels J, Heerkens Y, Nijhuis F. A new typology of work schedules: Evidence from a cross-sectional study among nurses working in residential elder care. Work. 2016 Apr 7.

67. Rodwell J, Fernando J. Managing Work Across Shifts: Not All Shifts Are Equal. J Nurs Scholarsh. 2016 Jul;48(4):397-405.

68. Nabe-Nielsen K, Tüchsen F, Christensen KB, Garde AH, Diderichsen F. Differences between day and nonday workers in exposure to physical and psychosocial work factors in the Danish eldercare sector. Scandinavian Journal of Work, Environment \& Health. 2009;35(1):48-55.

69. Arbuckle JL. IBM SPSS Amos 20 User's Guide. Crawfordville, FL: Amos Development Corporation; 2011

70. Anderson JC, Gerbing DW. Structural equation modeling in practice: A review and recommended twostep approach. Psychological Bulletin. 1988;103(3):12

71. Hu Lt, Bentler PM. Cutoff criteria for fit indexes in covariance structure analysis: Conventional criteria versus new alternatives. Structural Equation Modeling: A Multidisciplinary Journal. 1999;6(1):1-55.

72. Marsh HW, Hau K-T, Wen Z. In Search of Golden Rules: Comment on Hypothesis-Testing Approaches to Setting Cutoff Values for Fit Indexes and Dangers in Overgeneralizing Hu and Bentler's (1999) Findings. Structural Equation Modeling: A Multidisciplinary Journal. 2004;11(3):320-41.

73. Hayes AF. Beyond Baron and Kenny: Statistical Mediation Analysis in the New Millennium. Communication Monographs. 2009;76(4):408-20
74. Baron RM, Kenny DA. The moderator-mediator variable distinction in social psychological research: conceptual, strategic, and statistical considerations. J Pers Soc Psychol. 1986 Dec;51(6):1173-82.

75. Cohen J. A power primer. Psychological Bulletin. 1992;112(1):155-9.

76. Mills M, Taht K. Nonstandard Work Schedules and Partnership Quality: Quantitative and Qualitative Findings. J Marriage Fam. [Article]. 2010 Aug;72(4):860-75.

77. Portegijs W, Cloin M, Roodsaz R, Olsthoorn M. Lekker vrij? Vrije tijd, tijdsdruk en de relatie met de arbeidsduur van vrouwen. Den Haag: Sociaal en Cultureel Planbureau2016. Report No.: ISBN 97890 37707762.

78. Barthe B, Messing K, Abbas L. Strategies used by women workers to reconcile family responsibilities with atypical work schedules in the service sector. Work. [Research Support, Non-U.S. Gov't]. 2011;40 Suppl 1:S47-58

79. Demerouti E, Bakker AB, Geurts SAE, Taris TW. Daily recovery from work-related effort during non-work time. Current Perspectives on Job-Stress Recovery: Emerald Group Publishing Limited; 2009. p. 85-123.

80. Garde AH, Hansen AM, Hansen J. Sleep length and quality, sleepiness and urinary melatonin among healthy Danish nurses with shift work during work and leisure time. International Archives of Occupationa and Environmental Health. [Research Support, Non-U.S. Gov'tResearch Support, U.S. Gov't, P.H.S.] 2009 Nov;82(10):1219-28.

81. Greenhaus JH, Beutell NJ. Sources of Conflict between Work and Family Roles. The Academy of Management Review. 1985;10(1):76-88.

82. Bekker MH, Rutte CG, van Rijswijk K. Sickness absence: A gender-focused review. Psychol Health Med. [Review]. 2009 Aug;14(4):405-18.

83. Casini A, Godin I, Clays E, Kittel F. Gender difference in sickness absence from work: a multiple mediation analysis of psychosocial factors. Eur J Public Health. [Research Support, Non-U.S. Gov't]. 2013 Aug;23(4):635-42.

84. Ala-Mursula L, Vahtera J, Kouvonen A, Väänänen A, Linna A, Pentti J, et al. Long hours in paid and domestic work and subsequent sickness absence: does control over daily working hours matter? Occupational and Environmental Medicine. 2006 September 2006;63(9):608-16.

85. Vinje HF, Mittelmark MB. Job engagement's paradoxical role in nurse burnout. Nursing \& Health Sciences 2007;9(2):107-11.

86. Schaufeli WB, Bakker AB. Preliminary Manual UWES; Utrecht Work Engagement Scale. Utrecht University: Occupational Health Psychology Unit; 2004.

87. Simpson MR. Predictors of Work Engagement Among Medical-Surgical Registered Nurses. Western Journal of Nursing Research. 2009 February 1, 2009;31(1):44-65.

88. Koopmans L, Bernaards CM, Hildebrandt VH, de Vet HC, van der Beek AJ. Construct validity of the individual work performance questionnaire. J Occup Environ Med. 2014 Mar;56(3):331-7.

89. Tucker P, Knowles SR. Review of studies that have used the Standard Shiftwork Index: evidence for the underlying model of shiftwork and health. Applied ergonomics. 2008 Sep;39(5):550-64.

90. Weer $\mathrm{CH}$, Greenhaus $\mathrm{JH}$, Linnehan F. Commitment to nonwork roles and job performance: Enrichment and conflict perspectives. Journal of Vocational Behavior. 2010;76(2):306-16

91. Smith CS, Robie C, Folkard S, Barton J, Macdonald I, Smith L, et al. A process model of shiftwork and health. Journal of Occupational Health Psychology. 1999;4(3):207-18. 
92. Hakanen JJ, Peeters MCW, Perhoniemi R. Enrichment processes and gain spirals at work and at home: A 3-year cross-lagged panel study. Journal of Occupational and Organizational Psychology. 2011;84(1):8-30

93. Eurofound. Fifth European Working Conditions Survey. Luxembourg: European Foundation for the Improvement of Living and Working Conditions2012.

94. Kleiven M, Boggild H, Jeppesen HJ. Shift work and sick leave. Scandinavian Journal of Work, Environment \& Health. 1998:24 Suppl 3:128-33.

95. Van Poppel MNM, de Vet HCW, Koes BW, Smid T, Bouter LM. Measuring sick leave: a comparison of self-reported data on sick leave and data from company records. Occupational Medicine. 2002 December 1. 2002:52(8):485-90

96. De Raeve L, Kant I, Jansen NW, Vasse RM, van den Brandt PA. Changes in mental health as a predictor of changes in working time arrangements and occupational mobility: results from a prospective cohort study. Journal of Psychosomatic Research. 2009 Feb;66(2):137-45.

97. Galatsch M, Li J, Derycke H, Muller BH, Hasselhorn HM. Effects of requested, forced and denied shift schedule change on work ability and health of nurses in Europe -Results from the European NEXT-Study. BMC Public Health. 2013 Dec 5;13(1):1137.

98. Kant I, van Amelsvoort L. Applying a biopsychosocial perspective in occupational health: Easier said than done! Work. 2017;57(2):149-51.

99. Odle-Dusseau HN, Hammer LB, Crain TL, Bodner TE. The Influence of Family-Supportive Superviso Training on Employee Job Performance and Attitudes: An Organizational Work-Family Intervention Journal of Occupational Health Psychology. 2015 Dec 14. 
In the studies presented in this thesis, the target group is nurses working in residential elder care. This group has greatly varying types of work schedules, and high rates of health complaints and sickness absence. This thesis aimed to clarify whether the types of work schedules could act as a resource and have a positive effect on labour participation, in terms of well-being, motivation and sickness absence, of nurses working in residential elder care. In addition, this thesis aimed to clarify the relationship between home-related demands and home-related resources on the one hand, and participation of nurses working in residential elder care in terms of well-being, motivation and sickness absence, on the other. These aims were addressed in five different studies for which two datasets were used: one cross-sectional sample, and one longitudinal sample with organisational recorded sickness absence reports.

This chapter discusses the main findings of the studies, addresses theoretical and methodological considerations, makes suggestions for further research, and presents some recommendations for policy and practice.

\section{MAIN FINDINGS}

Two new instruments were developed to address the study aims: 1) an instrument to measure the 'work schedule fit with private life' (WSF) and 2) an instrument to classify nurses' types of work schedule. The first tool (to measure the WSF of nurses) is described in Chapter 2. Although most theories or models emphasise the negative effect of a work schedule on health, the beneficial elements of certain types of work schedules with respect to aspects related to well-being (e.g. valuable social time, and quality time with children) should also be considered (2). However, no suitable instrument was available to measure the fit of several important aspects related to shift work. Therefore, the first cross-sectional study was based on the work status congruence theory (3), in order to develop a valid and reliable scale to measure the work schedule fit with private life. Our instrument, the 'work schedule fit with private life' (WSF) scale, proved to be a reliable and valid construct (Chapter 2). Work-related factors were associated with the WSF. In turn, the WSF was associated with health, i.e. a better WSF was associated with fewer health problems thereby confirming its independent relation with health. However, the work schedule fit with private life did not mediate between work and home-related (external) characteristics of nurses on the one hand and health on the other. Furthermore, in this first study, the home-related external factors related to nurses' health supported the comparable relationships in the ICF model. Thus, in line with the ICF model used as a frame of mind for this thesis, nurses' health was shown to be related to both home-related and work-related external factors.

Typologies of work schedules generally use a dichotomous measure that roughly distinguishes between day workers, and non-day or shift workers (4), or a single shift characteristic (5). In our work, although a more extensive questionnaire would have better described the type of work schedule, the longer length would probably have increased the risk of non-response. In addition, a lengthy questionnaire decreases the feasibility and/or practical value for supervisors and/or human resource managers. In Chapter 3 we developed a new typology with the aim to combine the best of both worlds based on the actual work schedules in our second sample of nurses. This was reduced in a systematic way to a typology consisting of five types of work schedules. The study in Chapter 3 shows that this measure is a valid and reliable instrument for studies on work-related aspects of nursing, and classifies shifts into a more detailed level, thereby meeting the challenge to include more shift characteristics in research (5).

Based on this new typology, the study described in Chapter 4 reveals the considerable differences between the types of schedules regarding work schedule characteristics, nurses' sociodemographic characteristics, and nurses' appraisal of the work schedule. Nurses in type 3 schedules (three rotating shifts, the most demanding work schedule) were younger, higher educated, the least satisfied with the fit of their work schedule and private life, and experienced the least control over their work schedule compared to nurses with other types of work schedules. Therefore, other types of work schedules appear to offer more opportunities for older nurses to adjust the schedule to their preferences. The study in Chapter 4 also shows that nurses' participation in terms of well-being, motivation, and sickness absence is mainly related to differences between the types of work schedule, although the lifespan age also played a role.

The large differences between nurses working in the different types of work schedule also suggest that work schedules could be a resource for nurses. However, in relation to health outcomes, it is not always clear whether a phenomenon should be considered a resource or a demand (6). Our reasoning was based on the COR theory (7) and the Job Demands-Resource model $(6,8)$. These two theoretical approaches have gained support due to the growing interest in the benefits and positive aspects of work, rather than focusing solely on the negative aspects. Using our second sample and a longitudinal design, in Chapter 5 it was shown that a job resource, i.e. work schedule fit with private life, buffered the positive effect of a demanding type of work schedule on emotional exhaustion one year later. However, the other job resource - work schedule control - reinforced rather than buffered the effect of high work schedule demands on emotional exhaustion one year later. Further, it was found that work schedule fit with private life predicted work engagement one year later, especially in the presence of high demands of the work schedule. These findings underline the dynamic interactions between work-related resources and demands of the ICF model. In contrast to expectations based on the ICF model, personal resources (active coping, a healthy lifestyle) did not appear to be relevant.

The study in Chapter 5 shows that these findings were in line with the COR theory and the Job Demands-Resource model. Therefore, the potential of work schedule fit with private life for nurses working in residential elder care as a resource is confirmed. Work schedule control strengthened 
rather than buffered the positive relationship between work schedule demands and emotiona exhaustion one year later and is, therefore, not a resource.

Lastly, in line with the ICF model, we aimed to test the role of job resources with respect to participation, home demands, and resources. Moreover, it was aimed to establish whether the effect of home and job resources would be mediated by health complaints or by motivation. This thesis shows that for nurses working in residential elder care, health-related theories of sickness absence are supported. Home demands positively predict and job resources negatively predict sickness absence duration and sickness absence episodes via health complaints, and not via a motivational pathway. In line with the second principal of the COR theory, i.e. the gain spiral (7), those nurses with a better work schedule fit with private life are less vulnerable to resource loss and more capable of orchestrating resource gain. This is also underlined by the positive relationship between more job resources and higher motivation of nurses.

\section{THEORETICAL AND CONCEPTUAL IMPLICATIONS}

This thesis has revealed several theoretical implications that need to be considered with respect to the participation of nurses working in residential elder care in terms of well-being, motivation and sickness absence.

\section{Demands count, also home demands}

Although this thesis show that the work schedule fit with private life is considered to be a work-related resource, it is important to note that also negative effects of work schedule-related demands and home-related demands were found. Besides the work-related demands reported in many studies, in this thesis nurses working in residential elder care perceived their home situation as a demand and not a resource, and this predicted more sickness absence via more health complaints.

The concept of lifespan age emphasises the way nurses have arranged and organised their life and can be measured, for example, by means of the life stage or family status (9). Lifespan age was associated with participation (Chapter 4). The youngest nurses worked in the most demanding work schedules, but were relatively older (on average \pm 38 years). However, chronological and organisational age are hardly related to participation in terms of well-being, motivation and sickness absence. This again emphasises the importance of focusing on nurses' lifespan age, rather than on a specific age level, with respect to work participation.

Although our studies showed some indications that resources can be found in the home setting (Chapter 2 and 4), these were not confirmed longitudinally. The majority of nurses in our two samples were female. In the Netherlands, women are still expected to combine taking care of children and work. Generally, they experience a lower quality of their free time $(10,11)$. Also, they probably have less time to recover and use their free time to fulfil care and home tasks. Remarkably, our cross- sectional analyses showed that the number of children was related to increased participation, or protected against participation problems. According to the role accumulation theory, combining work and home may produce positive effects for employees (12). These findings might also indicate a selection effect: having children prompts employees to work their preferred type of work schedule, with fewer working hours per week $(13,14)$ as a conscious choice to arrange childcare in combination with the partner's job $(15,16)$. However, the interaction effects of home resources and work (schedule)-related demands were not tested.

Therefore, although causal processes still need to be elucidated, the home situation seems to be experienced by nurses as a demand rather than a resource. This thesis also shows that nurses' perception of their home situation is preferable to using more objective home characteristics (cf. 17).

\section{Work schedule fit with private life is a resource}

Many studies have demonstrated the negative consequences of job demands, whereas our studies show the potential of work schedules to diminish the negative effects on nurses' participation if the work schedule fits with their private life. This work provides insight into the work schedule as a resource on a relatively short term, i.e. a one-year timeframe for nurses with a demanding work schedule or high home demands.

This thesis considered work schedule fit with private life to be located 'outside' the self in the social and work-related contexts of the nurse. It represents the degree to which the work schedule fits with nurses' private life, particularly in relation to leisure time, family situation, social circumstances, sleep, and work-leisure time balance. The work schedule fit with private life was a better job resource for nurses in the one-year follow-up period than work schedule control. Moreover, it was a better resource than personal resources (e.g. active coping style, or healthy lifestyle), which are not predictive for higher participation of nurses working in residential elder care (Chapter 5).

The finding that work schedule fit with private life was a better job resource for nurses within the one-year timeframe than work schedule control (Chapter 5) might be attributed to our observational study design. However, it is in line with other ambivalent findings and problems associated with work schedule control. For example, Nijp et al. (18) found that the effect of work schedule control is mitigated by well-being and motivation. Access to more work schedule control seems important only when employees have a need for such access. Work schedule control might be effective in increasing participation without an actual change in the work schedule or working hours (19). This could imply that providing work schedule control fulfils the basic need of employees to control their environment (20). Moreover, shift workers, and healthcare workers in particular, tend to give high priority to family life and leisure time when scheduling their own shifts (21) and providing almost full control over their schedule might result in more demanding work schedules (19). Furthermore, nurses have to rely on colleagues and supervisors (22) when scheduling their work schedules, and a balance is required between their individual needs and the needs of the unit 
(23). Thus, individually focused work scheduling procedures could interfere with team cohesion (24, 25). Therefore, in this way, work schedule control might be experienced by nurses as a threat or a demand, rather than an opportunity to balance work schedule and private life; this is underlined by our findings in Chapter 5 .

This thesis has shown that (within the one-year timeframe) work schedule fit with private life can be seen as a stable resource to enhance work engagement and to buffer the effect of work schedule and home demands on emotional exhaustion.

\section{Antecedents of work schedule fit with private life}

This thesis not only examined the effects of work schedule fit with private life on participation, but also addressed the question as to what determines work schedule fit with private life. In this thesis, work-related factors such as high social support, low quantitative job demands, high job and work schedule control, the type of work schedule and home-related factors were associated with work schedule fit with private life, irrespective of personal factors such as age, taking care of children, and working history. However, there is a possibility that these variables interact or have a causal chain. Nurses have to negotiate with supervisors and colleagues about their schedule on the long term and may have to swap shifts on short notice. Garde et al. (19) and Beutell (26) found that more work schedule control was directly related to work schedule fit. Thus, there is a possibility that work schedule control leads to more social support via work schedule fit with private life (27).

\section{ICF as a frame of mind to study participation}

This thesis has shown that the ICF framework is a useful one to investigate the labour participation of nurses working in residential elder care. This thesis highlight the importance of contextual and home-related factors and health, over and above solely personal factors, to understand the impact on labour participation of nurses working in residential elder care. The ICF framework categorises the origin of the determinants without weighing the relationships between the variables under study $(1,28,29)$. Furthermore, the ICF framework addresses the complex interplay between these factors and guided the research aims of this thesis. Therefore, examining the effects of shift work on labour participation from a biopsychosocial perspective using the ICF framework seems a valuable contribution to the biomedical perspective as described by Kant and van Amelsvoort (30). Moreover, there is a need to elucidate the external and personal resources for work-related care and to incorporate the positive outcomes of work to improve our understanding of labour participation (31). This thesis provides knowledge related to these processes.

However, additional theoretical frameworks are required to support the pathways within the ICF framework. Therefore, the COR theory and the related Job Demands-Resource model were used. The COR theory (7) and Job Demands-Resource model (32) assume that: 1) job resources buffer the impact of job or home demands on health problems, 2) job resources predict positive outcomes, such as motivation, 3) job resources predict motivation, especially when job or home demands are high, and 4$)$ job resources are negatively associated with work-related demands $(6,33)$

In this thesis, all four assumptions were (partly) confirmed. Job resources predicted sickness absence duration and episodes via health complaints and were associated with motivation (Chapter 6). Furthermore, resources buffered the negative impact of demanding type of work schedule (Chapter 5); resources were more strongly related to motivational aspects than to health complaints (Chapter 6); and resources were especially important for participation, in terms of work engagement when a work schedule was demanding (Chapter 6). Finally, work schedule fit with private life was negatively associated with work-related demands, such as the type of work schedule, working hours, and work-related demands (Chapter 2 and 3). These findings were in line with the COR theory (7), which proved to be a valid basis for testing work schedule-related job resources (Chapter 5 and 6) Therefore, it appears valuable to examine the participation of nurses working in residential elder care from a resource perspective. Furthermore, our findings also add knowledge to the need to redefine the demands within the Job Demands-Resource model (6). Because work schedule fit with private life was positively related to motivation and negatively to health complaints, this concept can now be categorised as a resource. Therefore, the studies in this thesis show the value of using a resource-oriented approach for research on shift work.

Finally, in relation to the causal model presented in Chapter 6, it can be concluded that sickness absence was mainly explained through work-related and home-related aspects via health. In addition, the findings also confirm (although with some caution) that sickness absence among nurses is mainly health-related rather than motivation-related. This finding is in contrast with other studies (albeit among other work populations) that also showed a path to sickness absence via motivation (34-36). Our findings support the use of work stress models built on resource theories that specifically include home characteristics, such as the work-home resource model (37). It is likely that nurses are intrinsically motivated to work in their profession. However, factors related to the economic recession in 2009 and 2010 might have diminished the relationship between motivation and sickness absence. Although there was a nursing shortage at that time, during a recession health complaints tend to increase, sickness absence rates tend to decrease, and extrinsic motivation to work increases, which might explain the absence of a relationship found in our study (38, 39). On the other hand, employers' flexibility might also decrease during an economic crisis (40), which could lead to less than optimal work schedule fit with private life.

Therefore, although in most theories shift work is generally perceived as a demand that encompasses loss of energy, this thesis shows that the work schedule can be valued positively (within a one-year timeframe) as a resource and not as a demand, if the work schedule fits with the private life of nurses working in residential elder care. Therefore, it is important to examine the participation of nurses working in residential elder care from a resource perspective. Furthermore, the findings in Chapter 2 and 5 imply that work schedule fit with private life is relevant on an 
individual level, irrespective of personal variables such as organisational age, chronological age taking care of children, coping style, and a healthy lifestyle, etc. Work schedule fit with private life can directly influence participation in terms of well-being and motivation. Finally, work-related demands/resources, home-related demands/resources and personal demands/resources are shown to interact and influence nurses' participation in terms of well-being, motivation and sickness absence. The overall findings of the studies in this thesis are presented in Figure 3.
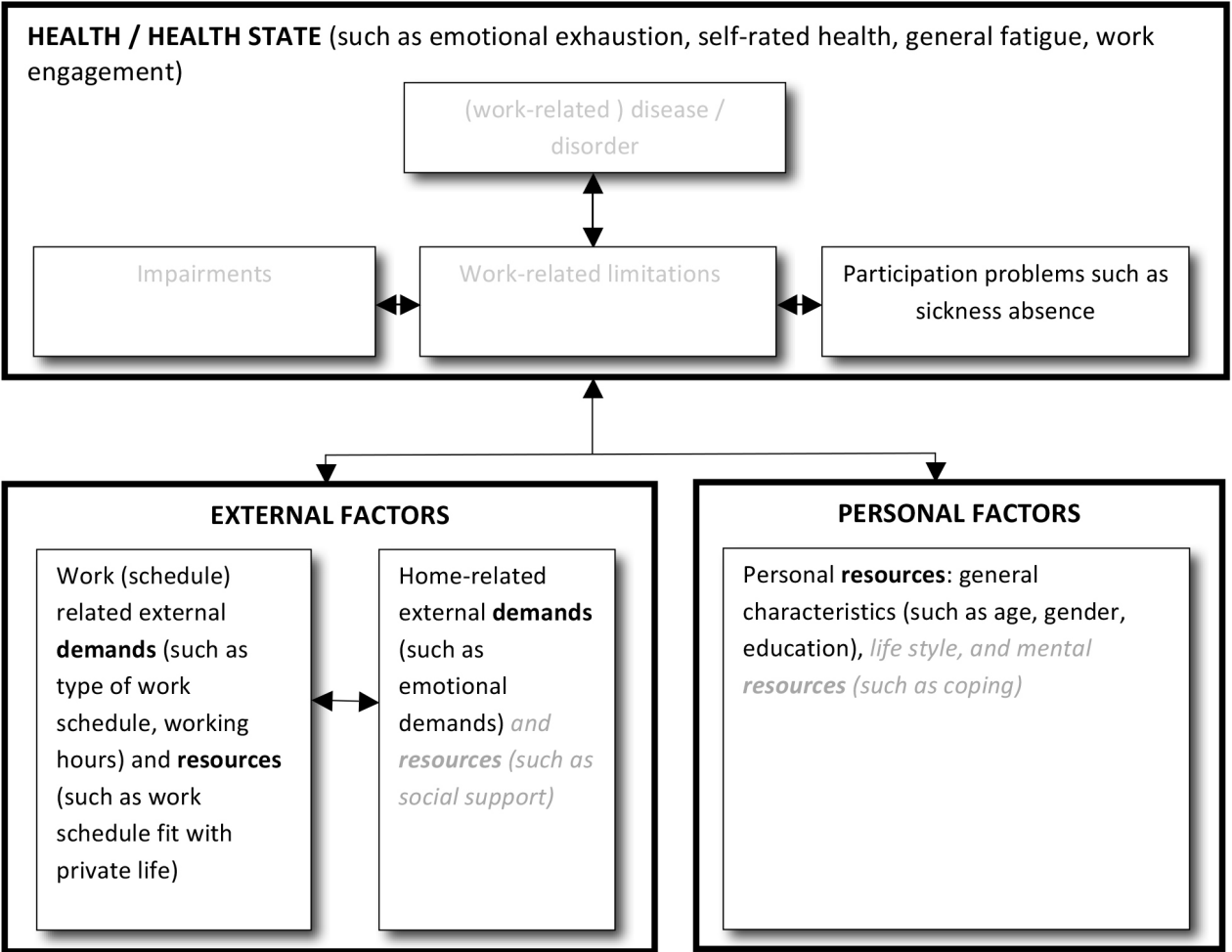

Figure 3: Extended ICF model (1) applied to labour participation of nurses working in residential elder care (determinants not confirmed in this thesis are shown in light grey italics.

\section{METHODOLOGICAL CONSIDERATIONS}

This thesis adds knowledge regarding how to measure the work schedule fit with private life for this specific nursing population within the context of residential elder care. The work schedule was evaluated as a resource by measuring the extent to which the work schedule allows nurses to achieve work goals, reduce job demands, and/or stimulate personal growth and well-being, and/or is linked to the process of creating and maintaining key resources. Similar relationships have been reported by others $(41,42)$. However, in contrast to our use of the 'work schedule fit with private life' (WSF) scale, these earlier researchers used the preferred work schedule, or the difference between the preferred and the actual work schedule. Furthermore, this thesis did not test whether the WSF scale is sensitive enough to measure the interaction between nurses' home demands and the work schedule. Nevertheless, an advantage of our measure is that it quantifies the degree of similarities between the preferred and the actual schedule.

The type of work schedule nurses worked in was measured by asking nurses to report the start and end times of their shifts, as well as asking for their actual working hours on a contractual basis. Based on these data a new typology was constructed. This typology resembles (for example) the more extensive typology of Härmä et al. (4) used to assess register-based working time patterns for epidemiologic studies; however, the typology of Härmä et al. included two additional dimensions, i.e. shift intensity and social aspects of working hours. The social aspects of working hours assess the realised and the wished shift, which is similar to our measurement of WSF. Furthermore, it assesses the free time between shifts; this was associated with the typology of work schedules in our research and seems to be a dependent construct. Moreover, it appears that not only the quantity of free time between shifts is important, but also what one does between shifts to recover (43). However, and although not restricted to free time, a healthy lifestyle was not related to participation in terms of well-being and motivation. In addition, to assess the type of work schedule of each nurse a self-report questionnaire was used; however, this could be liable to recall bias. For example, Härmä (44), showed that the validity of self-reported assessment of shift work varied depending on the specific work schedule; in particular, shift work without nightshifts appeared to be imprecise. Therefore, this could have led to underestimation of the effect of these shifts (e.g. the type two work schedule in our studies).

\section{Study sample}

The research in this thesis was based on two samples of nurses working in residential elder care. The size of the first sample was relatively small but, with respect to age, gender and education was comparable with the nursing population at that time in the Netherlands and comparable with the second sample. However, the working hours spent per week was lower in the second sample. The size of the second sample was comparable with, for example, the sample of nurses working in residential elder care used for the Survey among Nursing Employees (WNE, 45) and the statistical power seemed sufficient. Almost no differences were found between the nurses that responded and the nurses who did not (albeit the responders were slightly older). In both samples selection bias cannot be ruled out. If selection bias was caused by dropout, this could have led to an underestimation of the relationships found in our studies.

In addition, in both samples, selection bias through the 'healthy worker effect' cannot be ruled out. Less healthy workers might have accumulated less occupational exposure because they had already left the nursing profession or had switched to another type of work schedule (46). There 
are three possible manifestations for employees with shift work: 1) Primary selection: in which nursing students or inexperienced young nurses choose not to work in residential elder care or a specific type of work schedule (e.g. three rotating shifts). Selection for shift work seems to be predicted by health and a healthy lifestyle, whereas an unhealthy lifestyle predicted selection into fixed evening or fixed nightshifts. When nurses make a decision to apply for shift work, they probably estimate their ability to withstand a demanding type of work schedule. 2) Secondary selection: in which nurses switch to another type of work schedule or reduce their working hours when their type of work schedule does not match their personal health, or the work schedule fit with private life decreases. 3) Tertiary selection: in which shift workers selectively drop-out from the study population.

If primary selection was present in our studies $(47,48)$, this could have led to an underestimation of the real associations between the type of work schedule, the work schedule fit with their private life, and participation in terms of well-being, motivation and sickness absence. Also, there appears to be a secondary selection process present in our studies, probably caused by health problems, the type of work schedule, or due to differences in the nurses' life stages; this could also have led to an underestimation of the relationships. In line with Nabe-Nielsen, et al. (49) a shift change to other low demanding types of work schedule seems to occur more frequently among nurses with a type 3 work schedule than among nurses with other types of work schedules. With respect to age, decisions and choices around scheduling seem to be more influenced by lifespan age and less by their own health and well-being, especially for workers with more extensive family responsibilities $(13,14,50)$. If tertiary selection is present, this could have led to an underestimation of the relationships found in the present studies. For example, nurses' burnout is associated with leaving their profession (51). Therefore, if these points are in fact relevant, the relationships found in our studies would be an underestimation of the true relationships found in the nursing population.

\section{Timeframe}

It is difficult to draw firm conclusions about causality based on data with a one-year followup. Each determinant involved might have its own specific time course of cause and effect (52). A timeframe of (minimally) one year should be considered, because a suboptimal period could lead to underestimation of the true effects. Based on the findings of De Lange, Taris, Kompier, Houtman and Bongers (53), a one-year timeframe was chosen to investigate the effect of the work-related and home-related external and personal factors on participation. Although such a timeframe is preferable, changes might have occurred that were unable to monitor. Also, within this timeframe, a nurse might have changed the type of work schedule which could, in turn, have affected their home demands or work engagement; this could also lead to a change in work schedule. This effect of reversed causation was not measured in this thesis. About $25 \%$ of the nurses working in residential elder care changed their roster within this timeframe, whereas $85 \%$ stayed in the same type of work schedule as classified in this thesis (additional analysis). It is unknown when and why these changes occurred between the two time points.

The longer timeframe might explain the absence of a relationship between motivation and sickness absence, in particular sickness absence episodes. For example, nurses who were less motivated could have changed job tasks or adapted their working hours, which could have increased their motivation. Another reason for being cautious about causal inferences is that, although the research model was theoretically based, having at least three waves (preferably using latent growth models) would have enabled a full mediation test of our theoretical model (54) to explain sickness absence duration/episodes. Highly engaged nurses might perceive their work schedule fit with private life differently compared to nurses with low engagement.

\section{External validity}

This thesis indicates which nurses could benefit from using the type of work schedule as a resource: especially nurses within residential elder care with demanding work schedules, a demanding home situation, or a high life-span age could use the type of work schedule as a resource. However, because baseline measurements of the first sample were conducted in 2003 and of the second sample in October 2009, for external validity it is important to compare the characteristics of the nurses working in residential elder care when the questionnaire was filled-in to the current population of nurses working in residential elder care. Moreover, these data also need to be compared with the European population of nurses. For this, some specific aspects need to be taken into account, such as the greying of the nursing population, the increasing prevalence of self-employed nurses, nurses with a 'zero-hours contract', flex-workers, and the changing demographics of the clients. Although the mean age of the current population of nurses working in residential elder care in the Netherlands is generally higher, the proportion aged under 35 years and under 55 years is comparable to the sample used for this thesis. Also, there are less female nurses in the current population of nurses working in residential elder care and more of them are working more hours on a contractual basis (55).

With respect to the type of contract, the majority of nurses in the sample used for this thesis had a permanent contract and the remainder had a temporary contract, a minimum-maximum contract, or were on-call. Although the number of nurses with a permanent contract is expected to decrease further in the near future, the number of nurses with a permanent contract were comparable to the current nursing population; according to the Survey Nursing Employees 2016 (56) this situation has consolidated and has slightly decreased recently (55). Self-employed nurses are still mainly absent from the labour market (55), which is in line with a study by De Veer and Francke (57) showing that, among women, the intention to work as a self-employed nurse is low.

In conclusion, despite that changes are expected, the research sample used in this thesis are comparable to the current nursing population in terms of self-employment. However, due to the 
current unsecure working conditions, the results emerging from our studies may be underestimated, whilst the amount of possible resources will be overestimated for the current nursing population.

With respect to the European situation, large differences exist with regarding part-time work. The prevalence of part-time work of other European countries differs from that in the Netherlands, which is a leading country in part-time work (58); this also applies to nurses (59). Nurses with a permanent contract were slightly overrepresented compared to other European countries. Moreover, nurses in the Netherlands are still held (mainly) responsible for childcare tasks. The amount of time spent on care tasks (besides child care) was the highest in the Netherlands compared with other European countries. Regarding work-family conflict, in the NEXT study, nurses in the Netherlands scored the lowest compared to other European nurses (59). This is probably because the Netherlands has the highest percentage of informal child care compared to other European countries (60).

Although the prevalence of equal sharing of paid work has increased in the last decade in the Netherlands (61), traditional family supportive policies still exist. Other European countries (e.g Denmark, Sweden and Finland) have more dual-earner family supporting policies (62); e.g. some Scandinavian countries enable parents to combine work and family and stimulate a more equal sharing of paid and unpaid work $(63,64)$. These findings imply that extrapolation of the findings with respect to home demands to other European countries requires caution. Nurses working in other European countries might experience more home resources and less home demands.

Because both samples consisted mainly of female nurses, indirect gender differences in daily life-related and work-related stressors might have played a role with respect to sick leave $(65,66)$, and women are at increased risk for longer sickness absence because of their health (67). Problems with combining work and family are more common for women, which can cause gender differences in sickness absence (68). Furthermore, informal care giving is stimulated by governmental policies and remains primarily a woman's responsibility. In addition, informal caregivers seem to use their free time to fulfil informal care tasks (69). Male employees use their free time differently than female employees (11), e.g. it may be less urgent for them to perform care tasks or informal care. Therefore, it is reasonable to assume that nurses working in residential elder care have become increasingly involved in informal care alongside their paid employment; this applies to both samples included in our studies. Healthcare workers who provide more hours of informal care in their private lives are at risk for mental and physical health problems, more work-home interference, and sickness absence (69-71). Moreover, high job strain and informal care giving predict participation problems with respect to well-being, motivation and sickness absence (72). Our findings might be an underestimation of the current situation of nurses who combine their job and informal care, for whom work schedule fit with private life becomes increasingly important.

Although primarily focusing on night work, according to the Dutch Health Council there is evidence that night work increases the risk of diabetes mellitus and cardiovascular diseases (73) An additional analysis showed that, in the research sample, the prevalence of nurses with a chronic illness is comparable to that in the general working population $(74,75)$. However, as mentioned, because our nursing sample is not comparable with the general working population, caution is required when extrapolating the findings of this thesis to other groups.

The research model presented in Chapter 5 seems restricted to study populations with shift work consisting solely of female employees. However, the ICF as a frame of mind proved to be useful for research on participation in terms of motivation, well-being and sickness absence among employees who have some kind of shift work. It recognises the complex interactions that can cause participation problems and, therefore, contributed to the understanding of these interactions among nurses working in residential elder care. Furthermore, the COR theory was used to consider working time arrangements as a resource, and has also proven valuable for research on other populations with shift work and is a valuable attribution to the ICF model (31). Moreover, the study population used for this thesis concerns employees with specific work-related demands, i.e. working with patients or clients, and partially replicated the findings from other study populations $(35,36)$. Due to the flexibility of working time, the 24-hour economy, and the sharing of paid and unpaid work, the work schedule as a resource will gain importance for other research populations and should be incorporated in future research models. However, although the conceptual model may be applicable to other working populations, the present results on the strengths of the relationships found are mainly useful for female research populations, such as hospital nurses, and home care nurses.

\section{Outlook}

As described in the introduction, there have been a number of important changes in health care since the start of the research described in this thesis that might affect the implications of the conclusions of this thesis. Major changes are likely to occur with respect to the job content of nurses in elder care in the Netherlands. In 2015 the Social Support Act (Dutch: WMO) and the Chronic Care Act (Dutch: WLZ) were introduced to replace the Exceptional Medical Expenses Act (Dutch: AWBZ). Because of this, only high-level care is provided by nursing homes. Care for elderly with low-level care needs is no longer provided intramural. Care homes have largely disappeared and extramural care is replaced by informal care and home care. On the other hand, there is increasing demand for especially higher educated nursing personnel and new skills in residential elder care $(76,77)$. The care demands of clients in residential elder care will increase and will continue to differ between elderly groups, implying that elder care is a highly complex process. Extramurally, higher educated nurses are needed in home care due to the complex care demands in view of the policies to support client self-management strategies. However, the need for higher educated nurses should also be fulfilled by educating the current nursing population. In 2016, according to the Survey among Nursing Employees, about $92 \%$ of the current nursing population had a fixed contract (56); this decreased to $81 \%$ in 2017 (55). However, the number of self-employed nurses did not change and they were still largely absent. These changes are probably due to the closing 
of the care homes. Therefore, no major changes with respect to the nursing population within the remaining nursing homes are expected.

Furthermore, in 2018-2020 a shortage on the supply side is expected in (residential) elder care especially for nurses with higher educational levels. A larger part of the nursing population will probably work as a self-employed nurse. The working hours of nurses per week will also probably increase. This led the Minister for Health, Welfare and Sport to call for extra healthcare personne and to use the governmental budget for increasing quality of residential care only on extra personnel. Also, especially older female employees will be expected to perform more informal care tasks, particularly those working 28 hours per week or less (10). This implies that the future population of nurses will comprise older nurses performing more informal care tasks, and higher educated nurses performing more complex care tasks; however, this could be a risk for increased nurse attrition. Perhaps the recent changes could cause a shift from the problem to home care nursing

Recently, several surveys have shown that the work schedule and work related demands are still one of the main reasons for leaving nursing, that the shortage on the labour market is still a concern, as is combining work and private life of nurses. These consequences, caused among other things by the developments described earlier, show that the relevance and necessity of the work schedule and the fit between the work schedule and nurses' private life have only increased since the data were collected. There are no reasons to assume that the type of relationships between the variables has changed, but the strengths might have. The conclusions of this thesis have thus gained importance.

\section{Conclusions regarding external validity}

In summary, despite the current and (probable) future changes in elder care, the research findings in this thesis will still be valid in the near future for nurses working in Dutch residential care or home care for the elderly. Furthermore, the need for more working hours and higher educated nurses, in combination with comparable working conditions, will be required for a part of the current nursing population working in elder care. Because the samples used in the present studies differ from the current European nursing population, it is questionable whether the strengths of the relationships found in this thesis are entirely applicable for other European nurses. Nevertheless, our work emphasises the importance of the 'work schedule fit with private life' in the near future for, in particular, the Dutch situation.

\section{RECOMMENDATIONS FOR FUTURE RESEARCH}

The current work has provided new insights on the work schedule as a resource with respect to participation, in terms of motivation, well-being and sickness absence of nurses working in residential elder care. It also shows the role of the home domain with respect to participation. To further investigate these new insights, the following recommendations are made for future research.

One important research line should focus on 'work schedule fit with private life' (WSF) with respect to nurses' participation. Because the findings in this thesis are based on an observational design, implementing measures to increase work schedule fit with private life will not necessarily lead to a higher participation level of nurses. Therefore, an experimental design is recommended to further investigate this topic. Also, the long-term effects of WSF on, especially health need further investigation; for this, a prospective cohort study is required with a longer follow-up period. Although a one-year timeframe is preferable (53), shorter time intervals are also needed to control for the effect of work schedule changes on participation. To further test the mediation model used in this thesis, a multi-wave model should be used with at least three waves.

Second, regarding the discussion on gender, the instrument that we developed to measure WSF could only be used for this specific nursing context; whether this instrument is applicable to other populations requires further investigation. Although the WSF scale has proven reliable and valid, studies are needed to further elucidate its construct validity and predictive value. Others researchers have shown that it is possible to compose a short questionnaire that predicts employees at risk for participation in terms of sickness absence $(78,79)$. However, because home demands and WSF interact, it is unknown whether the WSF scale has sufficient sensitivity to measure this. Therefore, the WSF scale should be tested on different levels of home demands in different types of work schedules.

How nurses actually accomplish work schedule fit with private life needs further research. As described, the ICF model addresses the complex interplay between work-related, home-related and personal factors. For example, nurses with more social support (at home or at work) in combination with more work schedule control might be better able to adapt their actual schedule to their private life. In that case, WSF is a product of the interaction between work schedule control and social support. However, the interaction between work-related factors and home-related factors remains unclear. Qualitative research should further elucidate the role of work schedule control and social support with respect to WSF and refine the present findings and those of, for example, Swanberg McKechnie, Ojha, and James (27).

This thesis enables to improve or challenge the current conceptual frameworks used in studies on shift work $(2,80-83)$ which mainly focus on the undesirable impact or negative consequences (especially fatigue) of shift work. In line with the development to use work stress models in shift work research (84), it is important to include resources that help employees withstand the demands of the work schedule. Moreover, in view of a new approach in defining health $(85$, in short: the ability to adapt and self-manage), the inclusion of positive outcomes with respect to participation (and not only health complaints or fatigue) could be encouraged. 
This thesis and earlier research shows that the youngest nurses working in type 3 schedule, (rotating three shift pattern) and with a low lifespan age are an important focus group with respect to participation. Unfortunately, studies on the youngest nurses and/or intervention studies are lacking, and little attention is paid to the work schedule as a resource during nurses' vocational education. To monitor these groups, a cohort study with a longer time interval is needed, preferably starting during nurses' training/education. Moreover, a cohort study allows to control for the 'healthy worker effect', i.e. the result of selection into work (i.e. unhealthy workers are less likely to start to work irregular hours) and selection out of work (i.e. those with health problems are more likely to drop out). For example, exit interviews or interviews when nurses change their work schedule could be used. An example of such a cohort study which started during nurses' student period is that of Bakker, Kox and Roelofs, (86). Unfortunately, as the results of this thesis and research among students has shown (87), they do not focus on the work schedule fit with private life or work schedule-related resources to increase participation. Finally, the research model used (Chapter 6) and whether work schedule fit with private life is valued as a resource, needs to be validated in other study populations.

\section{PRACTICAL IMPLICATIONS/RECOMMENDATIONS FOR POLICY AND PRACTICE}

This chapter aims to translate the findings into preventive strategies for both practice and policy. First, it is recommended to monitor nurses' participation status in terms of their health status, and sickness absence. This thesis shows that nurses' sickness absence was health related. It is important to emphasise that work schedule features could affect health and well-being mediated by a mismatch of sleep-wake cycles and other important biological rhythms, as well as by sleep problems, lifestyle changes, or disturbed family and social life. Nurses tend to focus more on short-term benefits and less on long-term consequences, such as their own health. This raises the following concern: when nurses' focus primarily on family/social life and other short-term benefits when they schedule their own shifts, this might increase the number of working hours per shift. Then, participation problems might emerge on the longer term due to ignoring other important processes, such as sleep deprivation, insufficient recovery, and health. Therefore, monitoring should be undertaken by elder care organisations on a regular basis.

Furthermore, it is recommended that work schedule fit with private life be aimed for by residential elder care organisations to decrease home demands and increase participation of nurses. Moreover, elder care organisations should aim for work schedule fit with private life, rather than work schedule control, as a temporary measure to reduce emotional exhaustion or improve work engagement of nurses. It should be a general subject for discussion between supervisors and nurses to establish the best fitting work schedule. Although the value of the WSF scale as a practical tool is not yet evidence-based, the application of the WSF scale on a regular basis should be used in case of primary preventive actions. This could be achieved by using it (for example) during performance interviews with supervisors, or when nurses request a work schedule change. The focus should be on nurses with a high lifespan age or high home demands, nurses working in a type 3 work schedule, or the youngest nurses. However, to do so, future research should focus on the further (predictive) validation of the WSF scale. Because selection effects into shift work are present, intervention mapping should be used to develop preventive strategies. Nurse students should be better prepared and equipped for working shift work. Therefore, the WSF scale could be used, for example, during their practical internship. Nurse students should be informed how to increase their work schedule fit with their private life.

It is recommended that company physicians use certain types of work schedules as a tool for temporary solutions, especially type 1 and 5 work schedules. In this way it could be used as a so called Human Resource Bundle (88), i.e. specific human resource practices that help employees sustain their level of functioning in the face of (e.g.) new home demands, or to return to previous levels of functioning. This Human Resource Bundle is applied on an individual level for nurses with participation problems. Furthermore, it could be used for human resource managers to enhance team performance. Therefore, achieving a work schedule fit with private life is advantageous for both employers and employees.

It is recommended that, according to the findings in this thesis, it should be the employers' and nurse managers' responsibility to enhance work schedule fit with private life to increase nurses' participation in terms of motivation and well-being. This thesis shows that care organisations should focus on providing job resources and not on personal resources, such as an active coping style and a healthy lifestyle. According to the Dutch Working Conditions Act (Arbowet) (89), employers are obliged to facilitate employees to prevent health problems. According to Robroek et al., about $90 \%$ of employees thinks that it is good that the employer tries to improve their health, and only $20 \%$ thinks that this interferes with their privacy (90). Employers are obliged to promote and facilitate healthy behaviour on the work floor. For nurses working in residential elder care, participation should be a shared employer-employee responsibility.

Another way for nurse managers to facilitate nurses work schedule fit with private life could be the family-oriented supervisor behaviour (FSSB) Intervention (22). This is supported by the findings in Chapter 5 and 6, i.e. that home demands and job resources are related to participation in terms of motivation, well-being and sickness absence. This training and self-monitoring intervention for supervisors increases their family supportive behaviours (22); research shows that, especially emotional and instrumental support, role modelling behaviour of supervisors, and proactively creative work-family management were effective with respect to nurses' participation (91).

In the light of successful implementation of these recommendations, some aspects should be considered with respect to nurses with shift work. It is important to emphasise that, because the present research had a one-year timeframe, the longer-term effects of increasing work schedule fit 
with private life are unknown. Furthermore, working in different types of work schedules seems a risk factor for low availability of workplace (health) interventions. Participation levels are generally low during workplace interventions and are less likely to be reached by shift workers compared to dayworkers (92). Also, some nurses seems to be reached by implementation of stress-reducing activities and reorganisation of the working hours; about 30-50\% has participated in improvements (92). Fixed evening, fixed nights and variable shifts without nights need special attention. Other factors that contribute to participation are the quality of the supervisors, health complaints of nurses, and their beliefs $(92,93)$.

\section{Being self-employed and responsibility}

A different situation arises when nurses are self-employed: i.e. either the self-employed nurse is hired by an elderly care organisation, or she works independently. In the first situation, the organisation is responsible for the (psychosocial) work environment; in that situation, it is suggested to follow the recommendations mentioned above. In the latter situation, the self-employed are responsible for themselves; in that case, adequate knowledge and awareness is required to selfregulate appropriate behaviour, and the consequences, on the short and long term.

\section{CONCLUSION}

The work presented in this thesis contributes to the understanding of the work schedule as a resource for nurses working in residential elder care. Although several points need further clarification and additional studies are recommended, the work schedules of nurses working in residential elder care should be acknowledged as a resource to increase participation in terms of motivation, well-being and sickness absence. If, according to the nurses, the work schedule fits with their private life, this tends to maintain or increase their participation in terms of well-being motivation, and sickness absence.

\section{REFERENCES}

1. Heerkens YF, Engels J, Kuiper C, Van der Gulden J, Oostendorp R. The use of the ICF to describe work related factors influencing the health of employees. Disabil Rehabil. 2004 Sep 2;26(17):1060-6.

2. Caruso CC, Bushnell T, Eggerth D, Heitmann A, Kojola B, Newman K, et al. Long working hours, safety, and health: toward a National Research Agenda. Am J Ind Med. 2006 Nov;49(11):930-42.

3. Holtom BC, Lee TW, Tidd ST. The relationship between work status congruence and work-related attitudes and behaviors. Journal of Applied Psychology. 2002;87(5):903-15.

4. Härmä M, Ropponen A, Hakola T, Koskinen A, Vanttola P, Puttonen S, et al. Developing register-based measures for assessment of working time patterns for epidemiologic studies. Scandinavian Journal of Work, Environment \& Health. [Research Support, N.I.H., Extramural, Research Support, Non-U.S. Gov't]. 2015 May 1;41(3):268-79

5. Dall'Ora C, Ball J, Recio-Saucedo A, Griffiths P. Characteristics of shift work and their impact on employee performance and wellbeing: A literature review. International Journal of Nursing Studies. [Research Support, Non-U.S. Gov't Review]. 2016 May;57:12-27.

6. Schaufeli WB, Taris TW. A Critical Review of the Job Demands-Resources Model: Implications for Improving Work and Health. 2014:43-68.

7. Hobfoll SE, Shirom A. Conservation of resources theory: Applications to stress and management in the workplace. In: Golembiewski RT, editor. Handbook of organizational behavior (2nd ed, rev ed and exped). New York, NY US: Marcel Dekker; 2001. p. 57-80.

8. Demerouti E, Bakker AB. The Job Demands-Resources model: Challenges for future research. SA Journa of Industrial Psychology/SA Tydskrif vir Bedryfsielkunde. 2011;37(2):1-9.

9. Schalk R, van Veldhoven M, de Lange AH, De Witte H, Kraus K, Stamov-Roßnagel C, et al. Moving European research on work and ageing forward: Overview and agenda. European Journal of Work and Organizational Psychology. 2010;19(1):76-101.

10. Portegijs W, Cloin M, Roodsaz R, Olsthoorn M. Lekker vrij? Vrije tijd, tijdsdruk en de relatie met de arbeidsduur van vrouwen [A day off? Women's free time, time pressure and working hours]. Den Haag: Sociaal en Cultureel Planbureau2016. Report No.: ISBN 9789037707762.

11. Roeters A, Perez SA, de Boer A, editors. De combinatie van betaalde arbeid en zorgtaken (The combination of paid work and care tasks]. Den Haag: Sociaal en Cultureel Planbureau/Centraal Bureau voor de Statistiek.; 2016.

12. Peeters MCW, de Jonge J, Taris TW. An Introduction to Contemporary Work Psychology: Wiley; 2013.

13. Floderus B, Hagman M, Aronsson G, Marklund S, Wikman A. Work status, work hours and health in women with and without children. Occupational and Environmental Medicine. [Research Support, NonU.S. Gov't]. 2009 0ct;66(10):704-10.

14. Sandmark $H$, Hagglund $K$, Nilsson $K$, Hertting A. Understanding work ability: experiences of female assistant nurses in elderly care. Work. 2009;34(3):373-83.

15. Fagan C, Lyonette C, Smith M, Saldaña-Tejeda A. The influence of working time arrangements on work-life integration or 'balance': A review of the international evidence. Geneva: International Labour Office2012. 
16. Mills M, Taht K. Nonstandard Work Schedules and Partnership Quality: Quantitative and Qualitative Findings. J Marriage Fam. [Article]. 2010 Aug;72(4):860-75

17. Perrewé PL, Zellars KL. An Examination of Attributions and Emotions in the Transactional Approach to the Organizational Stress Process. Journal of Organizational Behavior. 1999;20(5):739-52.

18. Nijp HH, Beckers DG, Kompier MA, van den Bossche SN, Geurts SA. Worktime control access, need and use in relation to work-home interference, fatigue, and job motivation. Scandinavian Journal of Work, Environment \& Health. [Research Support, Non-U.S. Gov't]. 2015 Jul;41(4):347-55.

19. Garde AH, Albertsen K, Nabe-Nielsen K, Carneiro IG, Skotte J, Hansen SM, et al. Implementation of self-rostering (the PRIO-project): effects on working hours, recovery, and health. Scandinavian Journa of Work, Environment \& Health. 2012 Jul;38(4):314-26.

20. Smith L, Iskra-Golec I. Internal locus of control and shiftwork effects. Theoretical Issues in Ergonomics Science. 2003;4(3-4):327-39.

21. Nabe-Nielsen K, Lund H, Ajslev IZ, Hansen AM, Albertsen K, Hvid H, et al. How do employees prioritise when they schedule their own shifts? Ergonomics. 2013;56(8):1216-24.

22. Kossek EE, Hammer LB. Family Supportive Supervisory Behaviors (FSSB) Intervention Study: Effects on Employee's Work, Family, Safety, \& Health Outcomes. Summary of Findings from the National Institute for Occupational Safety and Health. 2008(Grant \# U010H008788.).

23. Bailyn L, Collins R, Song Y. Self-scheduling for hospital nurses: an attempt and its difficulties. Journal of Nursing Management. 2007;15(1):72-7.

24. Ingre $M$, Akerstedt $T$, Ekstedt $M$, Kecklund G. Periodic self-rostering in shift work: correspondence between objective work hours, work hour preferences (personal fit), and work schedule satisfaction. Scandinavian Journal of Work, Environment \& Health. [Research Support, Non-U.S. Gov't]. 2012 Jul;38(4):327-36.

25. Hansen ÅM, Nabe-Nielsen K, Albertsen K, Hogh A, Lund H, Hvid H, et al. Self-rostering and psychosocial work factors - A mixed methods intervention study. Applied Ergonomics. 2015;47:203-10.

26. Beutell NJ. Work schedule, work schedule control and satisfaction in relation to work-family conflict, work-family synergy, and domain satisfaction. Career Development International. 2010;15 (5):501 - 18

27. Swanberg JE, McKechnie SP, Ojha MU, James JB. Schedule control, supervisor support and work engagement: A winning combination for workers in hourly jobs? Journal of Vocational Behavior. 2011;79(3):613-24.

28. Martins AC. Using the International Classification of Functioning, Disability and Health (ICF) to address facilitators and barriers to participation at work. Work. 2015;50(4):585-93.

29. Koolhaas W, van der Klink JJ, Vervoort JP, de Boer MR, Brouwer S, Groothoff JW. In-depth study of the workers' perspectives to enhance sustainable working life: comparison between workers with and without a chronic health condition. J Occup Rehabil. 2013 Jun;23(2):170-9.

30. Kant I, van Amelsvoort L. Applying a biopsychosocial perspective in occupational health: Easier said than done! Work. 2017;57(2):149-51.

31. Heerkens YF, de Brouwer CPM, Engels JA, van der Gulden JWJ, Kant I. Elaboration of the contextual factors of the ICF for Occupational Health Care. Work. 2017;57(2):187-204.

32. Bakker AB, Demerouti E. The Job Demands-Resources model: State of the art. Journal of Managerial Psychology. 2007;22(3):309-28.

33. Bakker AB, Demerouti E. Job Demands-Resources Theory. In: Chen PY, Cooper. CL, editors. Wellbeing: A Complete Reference Guide, : John Wiley \& Sons, Ltd; 2014. p. 37 - 64.
34. Ten Brummelhuis $\mathrm{LL}$, ter Hoeven $\mathrm{CL}$, de Jong MDT, Peper B. Exploring the linkage between the home domain and absence from work: Health, motivation, or both? Journal of Organizational Behavior 2013;34(3):273-90

35. Schaufeli WB, Bakker AB, Van Rhenen W. How changes in job demands and resources predict burnout, work engagement, and sickness absenteeism. Journal of Organizational Behavior. 2009;30(7):893-917.

36. Bakker AB, Demerouti $E$, de Boer $E$, Schaufeli WB. Job demands and job resources as predictors of absence duration and frequency. Journal of Vocational Behavior. 2003;62(2):341-56.

37. Ten Brummelhuis LL, Bakker AB. A resource perspective on the work-home interface: the work-home resources model. Am Psychol. 2012 0ct;67(7):545-56.

38. GyesGuy V, Szekér L. Impact of the crisis on working conditions in Europe. EurWORK European Observatory of Working Life [serial on the Internet]. 2017: Available from: https://www.eurofound.europa.eu/ observatories/eurwork/comparative-information/impact-of-the-crisis-on-working-conditions-in-europe.

39. Sigursteinsdottir $\mathrm{H}$, Rafnsdottir GL. Sickness and sickness absence of remaining employees in a time of economic crisis: a study among employees of municipalities in Iceland. Soc Sci Med. 2015 May;132:95-102.

40. Sweet S, Besen E, Pitt-Catsouphes M, McNamara TK. Do options for job flexibility diminish in times of economic uncertainty? Work, employment and society. 2014;28(6):882-903.

41. Krausz M, Sagie A, Bidermann Y. Actual and Preferred Work Schedules and Scheduling Control as Determinants of Job-Related Attitudes. Journal of Vocational Behavior. 2000;56(1):1-11.

42. Nabe-Nielsen K, Kecklund G, Ingre M, Skotte J, Diderichsen F, Garde AH. The importance of individual preferences when evaluating the associations between working hours and indicators of health and well-being. Applied Ergonomics. 2010;41(6):779-86.

43. Zijlstra FRH, Sonnentag S. After work is done: Psychological perspectives on recovery from work European Journal of Work and Organizational Psychology. 2006;15(2):129-38.

44. Härmä M, Koskinen A, Ropponen A, Puttonen S, Karhula K, Vahtera J, et al. Validity of self-reported exposure to shift work. Occupational and Environmental Medicine. 2016 September 27, 2016.

45. Onderzoeksprogramma arbeidsmarkt zorg en welzijn [Research Programm Work in Care and Socia Welfare] [database on the Internet]. KIwa Caop. 2015 [cited 10-06-2016]. Available from: http://www. azwinfo.nl/.

46. Gommans F, Jansen N, Stynen D, de Grip A, Kant I. The ageing shift worker: a prospective cohort study on need for recovery, disability, and retirement intentions. Scandinavian Journal of Work, Environment \& Health. [Research Support, Non-U.S. Gov't]. 2015 Jul;41(4):356-67.

47. Nabe-Nielsen K, Garde AH, Tuchsen F, Hogh A, Diderichsen F. Cardiovascular risk factors and primary selection into shift work. Scand J Work Environ Health. 2008 Jun;34(3):206-12.

48. Axelsson J, Kecklund G, Gustavsson P, Rudman A. Selection into shift and night work. 20th International Symposium on Shiftwork and Working Time; "Biological mechanisms and risk management in the 24h society"; Stockholm, Sweden2011.

49. Nabe-Nielsen K, Quist HG, Garde AH, Aust B. Shiftwork and changes in health behaviors. Journal of occupational and environmental medicine. [Research Support, Non-U.S. Gov't]. 2011 Dec;53(12):1413-7.

50. Barthe B, Messing K, Abbas L. Strategies used by women workers to reconcile family responsibilities with atypical work schedules in the service sector. Work. [Research Support, Non-U.S. Gov't]. 2011;40 Suppl 1:S47-58. 
51. Heinen MM, van Achterberg T, Schwendimann R, Zander B, Matthews A, Kózka M, et al. Nurses' intention to leave their profession: $A$ cross sectional observational study in 10 European countries. Int J Nurs Stud. 2012 Oct.

52. Frese M, Zapf $D$. Methodological issues in the study of work stress: Objective vs subjective measurement of work stress and the question of longitudinal studies. 1994.

53. De Lange AH, Taris TW, Kompier MAJ, Houtman ILD, Bongers PM. The relationships between work characteristics and mental health: examining normal, reversed and reciprocal relationships in a 4-wave study. Work \& Stress. 2004 2004/04/01;18(2):149-66.

54. Lockhart G, MacKinnon DP, Ohlrich V. Mediation analysis in psychosomatic medicine research Psychosomatic medicine. [Research Support, N.I.H., Extramural]. 2011 Jan;73(1):29-43.

55. Jettinghof K, Van Hassel D, Joldersma C. AZWinfo Arbeid in Zorg en Welzijn 2016 [Work in Care and Social Welfare]. Zoetermeer: Panteia2017.

56. Joldersma C, Laarman-Wierenga M, Brink M. AZWinfo Arbeid in Zorg en Welzijn 2015 [Work in Care and Social Welfare]. Zoetermeer: Panteia2016.

57. De Veer A, Francke A. Werken als zelfstandige, of toch maar niet? [To work as a self-employed, or not?] TvZ, Tijdschrift voor Verpleegkundigen. 2009(7/8):34 - 5

58. Eurofound. Fifth European Working Conditions Survey. Luxembourg: European Foundation for the Improvement of Living and Working Conditions2012.

59. Hasselhorn H-M, Oginska H, Tackenberg P, Pokorski J, Estryn-Behar M, Camerino D, et al. NEXT - scientific results. Wuppertal: University of Wuppertal2005.

60. Eurostat. Other types of childcare by age group and duration - EU-SILC survey. 2017; Available from: http://appsso.eurostat.ec.europa.eu/nui/submitViewTableAction.do.

61. Portegijs W, Van den Brakel M. Emancipatiemonitor 2016 [Emancipation monitor 2016]. Den Haag: Sociaal Cultureel Planbureau en Centraal Bureau voor de Statistiek2016.

62. Camerino D. Gender Differences in Safety, Health and Work/Family Interference-Promoting Equity. In: Iskra-Golec I, Barnes-Farrell J, Bohle P, editors. Social and Family Issues in Shift Work and Non Standard Working Hours. Cham: Springer International Publishing; 2016. p. 153-79.

63. Abendroth AK, den Dulk L. Support for the work-life balance in Europe: the impact of state, workplace and family support on work-life balance satisfaction. Work, Employment \& Society. 2011;25(2):234-56.

64. Schwab K, Samans R, Zahidi S, Leopold TA, Ratcheva V, Hausmann R. Global Gender Gap Report 2016. Cologny/Geneva, Switzerland: World Economic Forum 2016.

65. Bekker MH, Rutte CG, van Rijswijk K. Sickness absence: A gender-focused review. Psychol Health Med [Review]. 2009 Aug;14(4):405-18.

66. Casini A, Godin I, Clays E, Kittel F. Gender difference in sickness absence from work: a multiple mediation analysis of psychosocial factors. Eur J Public Health. [Research Support, Non-U.S. Gov't]. 2013 Aug;23(4):635-42

67. De Rijk AE, Janssen N, Alexanderson K, Nijhuis F. Gender differences in return to work patterns among sickness absentees and their associations with health: a prospective cohort study in The Netherlands. Int J Rehabil Res. [Research Support, Non-U.S. Gov't]. 2008 Dec;31(4):327-36.

68. Nilsen W, Skipstein A, Ostby KA, Mykletun A. Examination of the double burden hypothesis-a systematic review of work-family conflict and sickness absence. Eur J Public Health. 2017 Jun 01;27(3):465-71.
69. Josten E, De Boer A. Concurrentie tussen mantelzorg en betaald werk [Competition between informal care and paid work]. Den Haag: Sociaal en Cultureel Planbureau2015

70. Boumans NP, Dorant E. Double-duty caregivers: healthcare professionals juggling employment and informal caregiving. A survey on personal health and work experiences. Journal of Advanced Nursing [Research Support, Non-U.S. Gov't]. 2014 Jul;70(7):1604-15.

71. Heitink E, Heerkens $Y$, Engels J. Informal care, employment and quality of life: Barriers and facilitators to combining informal care and work participation for healthcare professionals. Work. 2017;58(2):215-31

72. Mortensen J, Dich N, Lange T, Alexanderson K, Goldberg M, Head J, et al. Job strain and informa caregiving as predictors of long-term sickness absence: A longitudinal multi-cohort study. Scandinavian Journal of Work, Environment \& Health. 2017 Jan 01;43(1):5-14.

73. Gezondheidsraad. Gezondheidsrisico's door nachtwerk. Den Haag2017 Contract No.: 2017/17.

74. Douwes M, Hooftman W, Kraan K, Steenbeek R, Venema A, De Vroome E, et al. Kwaliteit van de arbeid, effecten en maatregelen in Nederland [Quality of work, consequences and measures in the Netherlands]. Leiden: TN02014 Contract No.: ISBN 978-90-5986-455-9.

75. Boot CR, Koppes LL, van den Bossche SN, Anema JR, van der Beek AJ. Relation between perceived health and sick leave in employees with a chronic illness. J Occup Rehabil. 2011 Jun;21(2):211-9.

76. Eggink E, Oudijk D, Woittiez I. Zorgen voor zorg. Ramingen van de vraag naar personeel in de verpleging en verzorging tot 2030 [Care for care. Estimations of the demand for elder care personell until 2030] Den Haag: Sociaal en Cultureel Planbureau2010.

77. Actiz. Working in elder care. Utrecht: Actiz; 2016 [cited 2016 29-02-2016]

78. Duijts SF, Kant I, van den Brandt PA, Swaen GM. Psychometrics and validation of a screening instrument for sickness absence. Occupational Medicine. [Validation Studies]. 2008 Sep:58(6):413-8.

79. Roelen CA, Heymans MW, Twisk JW, van Rhenen W, Pallesen S, Bjorvatn B, et al. Updating and prospective validation of a prognostic model for high sickness absence. International Archives of Occupational and Environmental Health. [Validation Studies]. 2015 Jan;88(1):113-22.

80. Tucker P, Folkard S. Working time, health, and safety : A research synthesis paper. Geneva: International Labour Office2012.

81. Knutsson A. Health disorders of shift workers. Occup Med (Lond). 2003 March 1, 2003;53(2):103-8.

82. Merkus SL, Holte KA, Huysmans MA, van Mechelen W, van der Beek AJ. Nonstandard working schedules and health: the systematic search for a comprehensive model. BMC Public Health. 2015 Oct 23;15:1084.

83. Olsson K, Kandolin I, Kauppinen-Toropainen K. Stress and coping strategies of three-shift workers. Le Travail Humain. 1990;53(2):175-88.

84. Härmä M. Workhours in relation to work stress, recovery and health. Scandinavian Journal of Work Environment \& Health. 2006 Dec;32(6):502-14

85. Huber M, Knottnerus JA, Green L, Horst Hvd, Jadad AR, Kromhout D, et al. How should we define health? BMJ. 2011;343.

86. Bakker E, Kox J, Roelofs P. SPRiNG sterk gestart in de zorg [SPRING a good start in health care] Verpleegkunde. 2016;3

87. Postma J, Tuell E, James L, Graves JM, Butterfield P. Nursing Students' Perceptions of the Transition to Shift Work: A Total Worker Health Perspective. Workplace Health Saf. 2017 Nov;65(11):533-8. 
88. Kooij D, Jansen PGW, Dikkers JSE, de Lange AH. Managing aging workers: a mixed methods study on bundles of HR practices for aging workers. The International Journal of Human Resource Management. 2014;25(15):2192-212

89. SZW Mo. Arbeidsomstandighedenwet [Dutch Working Conditions Act ]. Den Haag: Kluwer; 2017.

90. Robroek SJ, van de Vathorst S, Hilhorst MT, Burdorf A. Moral issues in workplace health promotion. International Archives of Occupational and Environmental Health. [Clinical Trial Research Support, Non-U.S. Gov't]. 2012 Apr;85(3):327-31.

91. Odle-Dusseau HN, Hammer LB, Crain TL, Bodner TE. The Influence of Family-Supportive Supervisor Training on Employee Job Performance and Attitudes: An Organizational Work-Family Intervention Journal of Occupational Health Psychology. 2015 Dec 14.

92. Nabe-Nielsen K, Jørgensen M, Garde A, Clausen T. Do working environment interventions reach shift workers? International Archives of Occupational and Environmental Health. 2016 2016/01/01;89(1):163-70.

93. Nabe-Nielsen K, Garde AH, Clausen T, Jorgensen MB. Does workplace health promotion reach shift workers? Scand J Work Environ Health. 2015 Jan:41(1):84-93. 


\section{SUMMARY}

In this thesis the results are described of the "Time for Care; Care for Time" study which focuses on the role of the work schedule, and the fit between the work schedule with private life as a resource in relation to participation in terms of well-being, motivation and sickness absence of nurses working in residential elder care.

Chapter 1 provides a general introduction on the background on participation of nurses working in residential elder care in terms of motivation, well-being and sickness absence in the Netherlands. There is an ongoing need to focus on nurses already working in residential elder care and their sustainable employment. Nursing in residential elder care is inextricably bound with shift work that is still one of the main reasons why nurses are dissatisfied with their job. The negative effects of shift work on health and labour participation is well documented, but studies on the specific effects of shift work for nurses working in residential elder care are scarce. Labour participation is a multifaceted and complex phenomenon which may involve i) work-related factors, ii) personal factors, and iii) health-related factors. It is known that work-related demands play a role in adverse work outcomes, and are likely to increase in the near future for nurses. However, despite the growing interest in the benefits of work, such benefits have hardly been reflected in conceptual frameworks in research on nurses working in residential elder care. A central hypothesis of this thesis is that certain resources have the potential to buffer the negative effect of work schedulehome- and person-related demands on the participation problems of nurses working in residential elder care. The Conservation of Resources theory incorporated into the extended International Classification of Functioning, Disability and Health (the ICF-model), was considered to be a suitable frame of mind to study the labour participation of these nurses. Therefore, this thesis focuses on work-, home- and person-related resources with a special focus on the work schedule and the work schedule fit with private life. It will be investigated whether a better fit between work schedule and private life could possibly serve as a solution for the labour participation problems of nurses.

Chapter 2 describes a cross-sectional survey among 144 nurses working in residential elder care. The research aim was to investigate if the work schedule fit with private life mediates the relation between work and home characteristics on the one hand and health on the other. A new scale to measure work schedule fit with private life was presented. All work characteristics, but no home characteristics, were associated with work schedule fit with private life. The work characteristics "job demands" and the home characteristics "autonomy at home" and "home demands" were associated with health. Work schedule fit with private life did not mediate between work/home characteristics and health. Those reporting more social support, lower job demands and more job autonomy perceived a higher work schedule fit with private life. Furthermore, the new scale to measure work schedule fit with private life (WSF) appeared to be a valid and reliable instrument.
Chapter 3 using a different dataset from the one used in chapter 2, describes a cross-sectional study among 498 nurses working in residential elder care in which a new typology of work schedules was developed to assess the work schedules of nurses with shift work and to validate this typology. Furthermore, an additional aim was to elucidate what the characteristics were of the nurses working in different types of work schedules. Five main types could be distinguished based on predetermined requirements and frequencies. Nurses working in these types of work schedules differed significantly with respect to socio-demographic, and family characteristics and their appraisal of their work schedule. Especially nurses with type 3 schedules (rotating three shift pattern) differed from the other nurses. They were on average the youngest group and worked on average the least years in the current job. They experienced the least fit of their work schedule with their private life, worked the most hours on average, commuted the most minutes per workday and had the fewest days off in between shifts. A typology of five main types of work schedules was thus proposed to be used in future research. Content validity of the typology was sufficient and the new typology seemed useful for research on work-related aspects of nursing.

Chapter $\mathbf{4}$ describes a cross-sectional study using the same research sample as in chapter 3 with the aim to explore differences in participation in terms of well-being, motivation and sickness absence between nurses working in the different types of work schedules and to establish to what extent different operationalizations of age might explain differences with respect to participation. Age was operationalized as chronological age, organisational age, life-span age, and functional age. Nurses' participation in terms of well-being, motivation and sickness absence appeared to be mainly related to differences between the types of work schedule rather than age. Fixed early shifts were characterised by the most positive aspects of participation in terms of well-being, motivation and sickness absence, and three rotating schedules by the worst aspects. To improve participation, organisations should implement a system in which nurses with different types of work schedules are monitored in combination with their life-span perspective.

Chapter 5 describes a longitudinal study among 247 nurses working in residential elder care including two waves of data collection with a one year follow-up using self-report questionnaires. The aim was to examine whether personal (active coping and a healthy lifestyle) and job resources (work schedule control and work schedule fit with private life) predict work engagement and emotional exhaustion, and whether interactions between personal resources/job resources and work schedule demands, predict work engagement and emotional exhaustion of these nurses. Moderated structural equation modelling was conducted to analyse the interactions between personal and job resources on the one hand, and work schedule demands on the other hand. Nurses suffer less from decreasing work engagement and emotional exhaustion due to work schedule demands when their work schedules fit with their private lives. Work schedule control did not buffer, but rather strengthened the positive relationship between weekly working hours and emotional exhaustion one year later. Job resources appeared to be more important for nurses' well-being than personal 
resources were. The findings in this chapter highlight the importance of the fit of a work schedule with nurse's private life, if the work schedule is demanding.

Chapter 6, the final study describes a longitudinal study using structural equation modelling analyses with a one year follow-up among 365 nurses based on survey data and registered sickness absence data. The aim was to elucidate the role and pathways of home demands, home and job resources with respect to sickness absence among nurses working in residential elder care. In addition, it was examined whether these relationships were mediated by health and motivation Structural equation modelling analysis was performed on registered sick leave data to examine which characteristics predict registered sickness absence periods and duration one year later. More job resources, like work schedule fit with private life, and more home demands predicted sickness absence one year later and were mediated through nurses' health rather than through nurses' motivation. Job resources were associated with higher work related motivation. Adapting the work schedule to the employees' private life and reducing home demands seem good measures to reduce health-related sickness absence within one year.

In Chapter $\mathbf{7}$ a discussion is provided of the main findings of this thesis, alongside with methodological considerations and implications for research and practice. This thesis contributes to the understanding of the work schedule as a resource for nurses working in residential elder care. Evidence has been found that the work schedules of nurses working in residential elder care should be acknowledged as a resource to increase participation in terms of motivation, well-being and sickness absence. Nurses working in residential elder care perceived their home situation as a demand and not a resource, and home demands together with job resources predicted more sickness absence via more health complaints. This thesis shows that sickness absence of nurses working in residential elder care among nurses is related to health problems rather than to lack of motivation for work. This again emphasises - with respect to labour participation - the importance of focusing on nurses' lifespan age, rather than on chronological or organisational age. Finally, it appears valuable to examine the participation of nurses working in residential elder care from a resource perspective.

Strengths of this research include the longitudinal design with a one-year timeframe and two new instruments: the WSF (work schedule fit with private life) to measure the work schedule fit with private life and to measure the type of work schedule of nurses working in residential elder care. The present results on the strengths of the relationships found are mainly useful for female research populations. Another limitation of this research is that due to the observational design causal processes still need to be elucidated. Second, forms of healthy worker effect may have been present: those nurses best adapted to shiftwork manage to keep working.

In conclusion, the findings of this thesis have implications for future research and practice. An example of an implication for research is an experimental design to further investigate the effect of work schedule fit with private life as a resource with respect to work participation for nurses working in residential elder care. The long-term effects of work schedule fit with private life on health need further investigation in a prospective cohort study with more than two measurements and a follow-up period longer than one year. For preventive strategies for both practice and policy, it is recommended to monitor nurses' participation status in terms of their health status, and sickness absence. It is recommended that work schedule fit with private life should be aimed for by residential elder care organisations to decrease participation problems of nurses. Occupational physicians might recommend change of types of work schedules to prevent health problems and sickness absence in individual nurses. 


\section{SAMENVATTING}

In dit proefschrift worden de resultaten beschreven van de "Care for time; time for Care"-studie waarin de rol van werktijdregelingen (aantal uren en verdeling van de uren over de dag en week) van verplegend en verzorgend personeel werkzaam in residentiële ouderenzorg centraal staat. Meer specifiek wordt in dit proefschrift de bestudeerd of de mate waarin het werkrooster bij het privéleven aansluit (hierna te noemen 'de ervaren fit tussen rooster en privéleven') een mogelijke hulpbron is om arbeidsparticipatie te verbeteren.

In Hoofdstuk 1 wordt een overzicht gegeven van de motivatie, het welzijn en het ziekteverzuim (aspecten van arbeidsparticipatie) van verplegend en verzorgend personeel, dat werkzaam is in de ouderenzorg (verpleeg- en verzorgingshuizen) in Nederland. Motivatie, welzijn en ziekteverzuim worden gezien als belangrijke aspecten van arbeidsparticipatie nu en in de toekomst, dus van duurzame inzetbaarheid. Verpleging en verzorging in de ouderenzorg zijn onlosmakelijk verbonden met onregelmatige werktijden. Werktijden en roosters zijn echter belangrijke redenen voor ontevredenheid van verplegend en verzorgend personeel met hun werk. De negatieve effecten van werktijden op de gezondheid en arbeidsparticipatie zijn goed onderzocht, maar studies over de specifieke effecten van werktijdregelingen voor verplegend en verzorgend personeel werkzaam in de ouderenzorg zijn schaars. Arbeidsparticipatie is een veelzijdig en complex fenomeen dat verklaard kan worden door i) werkgerelateerde factoren, ii) persoonlijke factoren en iii) gezondheidsgerelateerde factoren. Het is bekend dat werkgerelateerde taakeisen (factoren) een rol spelen bij de ongunstige werkgerelateerde uitkomsten en het is aannemelijk dat voor verplegend en verzorgend personeel deze taakeisen alleen maar zullen toenemen in de nabije toekomst. Ondanks de toegenomen belangstelling voor de positieve aspecten van arbeidsparticipatie, worden deze nauwelijks weerspiegeld in de conceptuele kaders in het onderzoek naar verplegend en verzorgend personeel werkzaam in de ouderenzorg In dit proefschrift is de Conservation of Resources-theorie gecombineerd met de International Classification of Functioning, Disability and Health (de ICF). Hieruit is een denkkader geconstrueerd om de arbeidsparticipatie van deze verpleegkundigen en verzorgenden te bestuderen. De centrale hypothese van dit proefschrift is, dat bepaalde hulpbronnen de potentie hebben om het negatieve effect van taakeisen op arbeidsparticipatieproblemen te verminderen. Dit proefschrift concentreert zich daarbij op werkgerelateerde, thuisgerelateerde en persoonlijke hulpbronnen waarbij onderzocht wordt of een betere ervaren fit tussen rooster en privéleven een mogelijke oplossing zou kunnen zijn voor de arbeidsparticipatieproblemen van verplegend en verzorgend personeel.

In Hoofdstuk 2 wordt een cross-sectioneel onderzoek beschreven onder 144 verplegenden en verzorgenden die werkzaam zijn in de ouderenzorg. Het doel van het onderzoek was om te onderzoeken of de ervaren fit tussen rooster en privéleven de relatie medieert tussen werk- en thuiskenmerken enerzijds en gezondheid anderzijds. Er werd eerst een nieuwe schaal ontwikkeld om de ervaren fit tussen rooster en privéleven te meten. Alle werkkenmerken bleken samen te hangen met de ervaren fit tussen rooster en privéleven, maar thuiskenmerken hangen niet samen met deze fit. De werkkenmerken "taakeisen" en de thuiskenmerken "autonomie thuis" en "thuistaken" hingen samen met de ervaren gezondheid van verplegenden en verzorgenden. De ervaren fit tussen rooster en privéleven medieerde niet de relatie tussen werk- en thuiskenmerken en gezondheid. Degenen die meer sociale steun, minder taakeisen en meer autonomie ervaren, hadden een betere fit tussen rooster en privéleven. Bovendien bleek de nieuwe schaal voor het meten van de fit tussen rooster en privéleven een valide en betrouwbaar instrument te zijn. Deze schaal werd in hoofdstuk 2 nog de SIW (Satisfaction with Irregular Working times) genoemd, en wordt in het Nederlands aangeduid met het acronym PRoF (Privé - Rooster Fit; zie appendix 2).

In Hoofdstuk 3 is een andere dataset gebruikt dan die in hoofdstuk 2. In hoofdstuk 3 wordt een cross-sectioneel onderzoek beschreven onder 498 verplegenden en verzorgenden werkzaam in de ouderenzorg. Daarin is een nieuwe typologie van roosters ontwikkeld en gevalideerd om de roosters van verplegend en verzorgend personeel met onregelmatige werktijden binnen de ouderenzorg te kunnen classificeren. Het doel was om na te gaan wat de kenmerken zijn van de verplegenden en verzorgenden werkzaam in elk type rooster. Hiervoor zijn de oorspronkelijke typen eerst gecategoriseerd in vijf hoofdtypen op basis van vooraf opgestelde eisen. Verplegenden en verzorgenden binnen de vijf typen verschilde aanzienlijk met betrekking tot sociaal-demografische en gezinskenmerken en hun waardering van het rooster. Vooral verplegend en verzorgend personeel met type 3-roosters (drie-roterende diensten) verschilden van de verpleegkundigen met de andere typen roosters. Ze waren gemiddeld de jongste groep en werkten de minste jaren in de huidige baan. Ze ervoeren de laagste fit van hun rooster met hun privéleven, werkten gemiddeld de meeste uren, hadden de langste reistijd per werkdag en hadden de minste vrije dagen tussen de diensten door. De inhoudsvaliditeit van de typologie was voldoende en de nieuwe typologie lijkt bruikbaar voor onderzoek naar arbeidsgerelateerde aspecten van verpleging en verzorging in de ouderenzorg.

In Hoofdstuk 4 wordt een cross-sectioneel onderzoek beschreven met dezelfde onderzoekspopulatie als in hoofdstuk 3. Het doel was om 1) de verschillen in arbeidsparticipatie op het gebied van welzijn, motivatie en ziekteverzuim te onderzoeken tussen verplegend en verzorgend personeel werkzaam in de verschillende typen roosters, en 2) in welke mate leeftijd eventuele verschillen in arbeidsparticipatie verklaart. Leeftijd werd geoperationaliseerd als': chronologische leeftijd, organisatieleeftijd, leeftijd van de privésituatie (hoe op een punt in hun levensloop de privésituatie is ingericht) en de leeftijd van de gezondheid. De arbeidsparticipatie (motivatie, welzijn en ziekteverzuim) van verplegend en verzorgend personeel bleek vooral samen te hangen met type rooster, in plaats van met leeftijd. Alleen de leeftijd van de privésituatie was gerelateerd aan motivatie, welzijn en ziekteverzuim. Vaste vroege diensten werden gekenmerkt door de meest positieve aspecten van arbeidsparticipatie (motivatie, welzijn en weinig ziekteverzuim), en

1 Zie o.a.: Nauta A, De Lange AH, Görtz S. Lang zullen ze leven, werken en leren. Een schema voor het begrijpen en beïnvloeden van inzetbaarheid gedurende de levensloop. Gedrag en Organisatie. 2010;23(2):136 -57 
drie-roterende diensten met de meest slechte aspecten. Om de arbeidsparticipatie te verbeteren zullen organisaties binnen de ouderenzorg een systeem moeten implementeren waarin verplegend en verzorgend personeel een rooster krijgen dat past bij hun leeftijd van de privésituatie.

In Hoofdstuk 5 wordt een longitudinaal onderzoek beschreven onder 247 verplegenden en verzorgenden werkzaam in de ouderenzorg. Met een follow-up van één jaar werden met behulp van vragenlijsten data verzameld. Het doel was om te onderzoeken of persoonlijke hulpbronnen (actieve coping en een gezonde levensstijl) en werkgerelateerde hulpbronnen (controle over werktijden en de ervaren fit tussen rooster en privéleven) bevlogenheid en emotionele uitputting voorspellen, en of interacties tussen deze hulpbronnen en type rooster, bevlogenheid en emotionele uitputting voorspellen. Moderated structural equation modelling werd gebruikt om de interacties tussen persoonlijke en werkgerelateerde hulpbronnen en een veeleisend rooster te analyseren. Verplegend en verzorgend personeel heeft minder last van de afnemende werkbevlogenheid en emotionele uitputting als gevolg van de eisen van het werkrooster wanneer het rooster aansluit bij het privéleven De mate van invloed op de planning van het rooster verminderde niet, maar versterkte juist de positieve relatie tussen de hoeveelheid gewerkte uren en de emotionele uitputting van verplegenden en verzorgenden een jaar later. Werkgerelateerde hulpbronnen bleken dus belangrijker te zijn voor motivatie en welzijn van verplegend en verzorgend personeel dan persoonlijke hulpbronnen. De bevindingen in dit hoofdstuk benadrukken het belang van werktijdregelingen voor verplegend en verzorgend personeel, zeker als het rooster veeleisend is.

In Hoofdstuk 6, wordt een longitudinaal onderzoek beschreven met een follow-up van 1 jaar bij 365 verplegenden en verzorgenden op basis van vragenlijsten en geregistreerde ziekteverzuimgegevens. Het doel was om de rol te verduidelijken van thuistaken, thuisgerelateerde hulpbronnen en werkgerelateerde hulpbronnen met betrekking tot ziekteverzuim. Daarnaast werd onderzocht of deze relaties werden gemedieerd door gezondheid en motivatie. Structural equation modelling analyse werd uitgevoerd om te onderzoeken welke kenmerken het aantal geregistreerde ziekteverzuim perioden en verzuimduur een jaar later voorspelden. Werkgerelateerde hulpbronnen met name de fit tussen rooster en privéleven en meer taakeisen thuis voorspelden ziekteverzuim een jaar later. De gezondheid en niet de motivatie van verplegend en verzorgend personeel was hierbij de mediërende factor. Werkgerelateerde hulpbronnen waren gerelateerd aan een hogere werkgerelateerde motivatie, maar motivatie had geen relatie met ziekteverzuim. Het verhogen van de fit tussen rooster en privéleven van verplegend en verzorgend personeel en het verlagen van de taakeisen thuis lijken dus een goede maatregelen om ziekteverzuim binnen een jaar te verminderen.

In hoofdstuk 7 worden de belangrijkste bevindingen van dit proefschrift besproken, en methodologische overwegingen en implicaties voor onderzoek en praktijk beschreven. Dit proefschrift draagt bij aan het besef dat werktijdregelingen als hulpbron kunnen dienen voor verplegend en verzorgend personeel werkzaam in de ouderenzorg. Er is bewijs gevonden dat een fit tussen rooster en privéleven hun arbeidsparticipatie in termen van motivatie, welzijn en minder ziekteverzuim, kan verhogen. Verplegend en verzorgend personeel beschouwen hun thuissituatie als een taakeis die energie vergt en niet als een hulpbron. Dit proefschrift laat zien dat het ziekteverzuim van verplegend en verzorgend personeel werkzaam in de residentiële ouderenzorg voornamelijk gerelateerd is aan gezondheidsklachten en niet aan gebrek aan motivatie. Wat de arbeidsparticipatie betreft, is in dit proefschrift nogmaals het belang benadrukt van het focussen op de leeftijd van de privésituatie van verplegend en verzorgend personeel, in plaats van op een chronologische leeftijd of leeftijd van de professionaliteit. Ten slotte lijkt het waardevol om de arbeidsparticipatie van verplegend en verzorgend personeel werkzaam in de ouderenzorg vanuit een perspectief te benaderen en te onderzoeken waarin naast taakeisen ook hulpbronnen centraal staan.

Sterke punten van dit onderzoek zijn het longitudinale ontwerp met een jaar follow-up en twee nieuwe instrumenten: de PRoF (Privé-Rooster Fit) voor het meten van de fit tussen rooste en privéleven en een classificatiesysteem voor onderzoek om roosters terug te brengen tot vijf hoofdtypen. De huidige resultaten over de sterkte van de gevonden relaties zijn vooral nuttig voor vrouwelijke onderzoekspopulaties werkzaam in zorg en verpleging. Een beperking van dit onderzoek is dat - als gevolg van de observationele opzet -, causaliteit nog verder gevalideerd moet worden. Ten tweede waren mogelijk vormen van een healthy-worker effect aanwezig: juist het verplegend en verzorgend personeel dat het best aangepast is, aan bijvoorbeeld de onregelmatige werktijden, blijft werken.

Concluderend hebben de bevindingen van dit proefschrift implicaties voor toekomstig onderzoek en praktijk. Een voorbeeld van een implicatie voor onderzoek is een experimentele onderzoeksopzet om het effect van de fit tussen rooster en privéleven verder te onderzoeken. De langetermijneffecten van de fit tussen rooster en privéleven, met name op de gezondheid, moet verder worden onderzocht in een prospectieve cohortstudie met meer dan twee metingen en een follow-up periode langer dan een jaar. In het kader van preventieve strategieën voor zowel de praktijk als voor beleid, wordt aanbevolen aan leidinggevenden in de verpleging en verzorging om de motivatie, het welzijn en het ziekteverzuim structureel op de agenda te plaatsen tijdens formele momenten en tijdens informele momenten oog te hebben voor de relatie tussen rooster en welzijn en motivatie. Het wordt aanbevolen dat verpleeghuizen werktijdregelingen hebben waarmee een verplegende of verzorgende een rooster kan kiezen dat past bij haar privéleven. Hierdoor kan de gezondheid en motivatie vergroot worden en het verzuim verlaagd. Ook bedrijfsartsen kunnen verandering van rooster aanbevelen om hiermee gezondheidsproblemen en verzuim te voorkomen. 


\section{VALORISATION}

This thesis focuses on the fit between the work schedule and private life, which is studied as a potential resource in relation to work participation. The current work has provided new insights that the work schedules indeed could be a resource to improve work participation, in terms of motivation, well-being and sickness absence of nurses working in residential elder care. It also shows the role of the home domain as a domain that threatens work participation. Despite the results of this research being gathered in an observational study, several findings can potentially be valorised.

\section{What should be valorised?}

First, as mentioned above, one solution to increase work participation could be to optimise the fit of the work schedule with an individual nurse's private life. This thesis underlines that it is important that a nurse has a work schedule that, according to her, fits with her private life to increase well-being and motivation. This fit with private life could, for example, be discussed with (HR) supervisors and nurse managers. If the nurse has health complaints, or is already absent, the occupational physician can advise that the nurse should have a work schedule that fits better with her private life. To get more insight into that fit, the employee can first complete the WSF questionnaire ('work schedule fit with private life'), which is described in chapter two and is available from the authors in English and in Dutch (1). Ultimately, this instrument might be processed as E-health application so that nurses can monitor and adjust their fitness on regular bases.

Second, the new typology of work schedules presented in this thesis could be introduced in the context of human resource practices. Some types of work schedules (e.g. type 3 rotating work schedule) seem more demanding than for example type 1 work schedule (which is a fixed early shift). Firstly, the typology can be used to identify risk groups for reduced work participation, which seem to be the nurses working in constantly in rotating work schedules (type 3). These nurses are in need of more support on dealing with irregular working hours and its consequences and combining work and private life. As the majority of young nurses work in type 3 schedules, human resources management easily overlooks this risk group.

Secondly, it can be used in the context of job crafting (2): nursing and care staff working in residential elder care homes can adapt their work environment to their needs. Job crafting seems to be a dynamic process between the person and the environment. In particular for nurses, changing to another type of working time arrangement may be a mean to optimise work participation during different phases of the lifespan. These are examples of so-called HR Bundle of 'accommodative' practices which are specifically aimed at 'sparing' (i.e. giving fewer obligations and more privileges to) workers or bundle HR practices that could help nurses to maintain their current levels of functioning in the face of new challenges, or to return to previous levels after a loss.
The insights from this thesis that, in addition to job resources, home demands are related to, or can influence, work participation, also provides input for interventions among care workers in nursing homes. In training or in workshops by for example consultancy companies, the individual reduction of home demands must be part of group and individual training sessions. Different adaptive strategies to improve work-life balance can be taught and implementation of these strategies in individual lives be supported.

Because in the current research no influence was found of a healthy lifestyle and work time control on work participation, it seems to be unnecessary to focus on this to improve work participation in the short term. This thesis also emphasizes the importance of health complaints with respect to work participation. There is an ongoing discussion on responsibility for employees' well-being, but it should be monitored by the employer on a regular basis. This is in line with our findings that job resources seem more important to decrease sickness absence than personal resources.

Further, to improve work participation of nurses, more attention should be paid to notice (early signs of) emotional exhaustion, general fatigue, psychosomatic health complaints, lack of work engagement, and negative work-home interference. This can be done informally and in performance interviews in which the fit with the work schedule is also a central point. This requires that supervisors are trained to register these signs and in starting an (in)formal conversation on these signs and on solutions with the nurse. There are indications that such supervisor behaviour is an important factor that strongly influence or prevent the consequence of work related demands (3-5). In a more formalized way, these complaints can be checked during health checks, but again such check needs to be followed by a conversation on solutions. This thesis and earlier research show that the youngest nurses working in type 3 schedule, (rotating three shift pattern) or nurses with a low lifespan age are an important group to focus on with respect to work participation Irregular working hours are still an important reason for nurses to leave the job. Students also expect that it will contribute to problems in social life, health and performance after their transition to longer and irregular working hours. However, during the study little attention is paid to working in irregular working hours. Therefore, it seems useful to prepare students for irregular working hours during their working phase (6). This problem has been confirmed in qualitative research by a HAN-Sport Studies student (7). Recent American research (6) shows that nursing students need support during their education to deal with irregular working hours in relation to their personal performance. Such support could take place by workshops, educational units and / or as a point of attention during internship interviews. The WSF questionnaire could serve as input for organizing workshops and directing internship interviews.

\section{How it was valorised}

During the PhD research, several activities were performed to valorise the findings of this research: 
- First, the main findings were reported during the two moments of data collection to the HRmanagers of the participating organizations and, via newsletters, reported to the nursing and care staff of the participating residential elder care organizations.

- Second, both instruments (the WSF and the new typology of work schedules) were used in a questionnaire that was implemented for educational purposes for Bachelor students within the HAN University of Applied Sciences within the work and health theme [Healthy Business] to assess the type of work schedule and the fit with private life of employees from different types of labour organizations.

- Third, the results from the two research waves were presented during: Symposia of Shiftwork and working Time 2011 and 2015 attended by professionals from science, consultancy firms and practice organizations; during the 15th Conference of the European Association of Work and Organizational Psychology in 2011, and during the Sustainable Employability conference: Challenges for HRM Innovation 2013.

- Fourth, practical recommendations have been processed based on chapter five for the magazine for occupational and insurance medicine [Tijdschrift voor Bedrijfs- en Verzekeringsgeneeskunde, TBV] and the questionnaire has been used in another PhD trajectory in the US.

- Fifth, manuals for using the WSF questionnaire in Dutch and English were developed, with cut-off points based on the $25^{\text {th }}$ and $75^{\text {th }}$ percentiles.

- Sixth, the WSF questionnaire was made available for use by "Bevlogenleiderschap.nl", a consultancy organization, for a training in management life and vitality in health care ["Leidinggeven aan bevlogenheid"].

It is important for the valorisation to realize that the context in the Netherlands has changed during the period that the research took place and from the moment this thesis was completed. Major changes have occurred with respect to the job content of nurses in elder care in the Netherlands. In 2015 the Social Support Act (Dutch: WMO) and the Chronic Care Act (Dutch: WLZ) were introduced to replace the Exceptional Medical Expenses Act (Dutch: AWBZ). Less elderly have entered residential elderly care: 119,063 elderly in 2010 and 115,321 elderly people in 2017 (8), and more elderly people continue to live at home. For example, in the age group of 70 years or older, in 19971 1,413,049 elderly lived at home, in 2015 1,993,253 elderly lived at home and in 2018 2,239,579 elderly lived at home (9). Research by the Dutch Healthcare Authority (NZa) shows that $94 \%$ of all 65 - years old and of all over 85 -years old $70 \%$ still live at home (10). Because of this, only high-level care is provided to clients in nursing homes and all medium and low-level care at home. These changes have contributed to an increasing complexity and intensification of care in nursing homes. More and higher educated personnel is needed because patients in nursing homes have more complex problems. This is accompanied by an increase in work related load and a greater turnover and a shortage of nursing staff (11).
As a consequence, the relevance of the role of the work schedule and the fit between the work schedule and private life has gained importance. This is particularly the case for nursing staff working in residential nursing homes, but also, for example, for hospital staff.

Overall, the results of this thesis are relevant to many stakeholders such as nurses of residential elder care organizations, nurse managers, supervisors, Human Resource-professionals and occupational physicians. They can use the findings during their practice. Also, the findings can encourage these professionals to improve their work activities on an individual level. Hopefully, it contributes to keeping a sustainable nursing population and consequently to the quality of care for older people staying in residential elder care homes.

\section{REFERENCES}

1. Peters V, Boumans NP, De Rijk AE. Handleiding Prive-Rooster-Fit-vragenlijst (PRoF) Maastricht - Nijmegen: Maastricht University - HAN University of Applied Sciences 2018.

2. Dorenbosch L, B. Bakker A, Demerouti E, van Dam K. Job crafting: The psychology of customizing jobs. Introduction to the special issue2013.

3. Cotton P, Hart PM. Occupational Wellbeing and Performance: A Review of Organisational Health Research Australian Psychologist. 2003;38(2):118-27.

4. Crain TL, Stevens SC. Family-supportive supervisor behaviors: A review and recommendations for research and practice. Journal of Organizational Behavior. 2018;39(7):869-88.

5. Sloten Gv, Nauta A. De dialoog als vroege poortwachter: open overleg voorkomt verzuim [The dialogue as an early gatekeeper: open consultation prevents absenteeism]. Tijdschrift voor HRM. 2004:4(7):79-103.

6. Postma J, Tuell E, James L, Graves JM, Butterfield P. Nursing Students' Perceptions of the Transition to Shift Work: A Total Worker Health Perspective. Workplace Health Saf. 2017 Nov;65(11):533-8

7. Biezenaar E. Uitval verpleegkundigen met onregelmatige werktijden kort na de transitie van school naar werk [Drop-out nurses with irregular working hours shortly after the transition from school to work] [Bachelorthese] Nijmegen: Hogeschool van Arnhem en Nijmegen; 2014 [updated 01-02-2014].

8. Statistics Netherlands. CBS Huishoudens; grootte, samenstelling, positie in het huishouden, 1 januari [Statistics Netherlands; Households; size, composition, position in the household, January]. Voorburg Heerlen: Centraal Bureau voor de Statistiek (CBS)2018.

9. Statistics Netherlands C. Personen in huishoudens naar leeftijd en geslacht, 1 januari [Persons in households by age and gender, 1 January]. Voorburg/Heerlen: Centraal Bureau voor de Statistiek (CBS)2018.

10. (NZa) DHA. Monitor zorg van ouderen [Monitor care of the elderly]. Utrecht: Nederlandse Zorgautoriteit NZa; 2018 [cited 2018 01-06-2018]

11. Kalkhoven F, van der Aalst M. Tekorten in de zorg leiden tot problemen, maar bieden ook kansen [Nursing shortages lead to problems, but also offer opportunities]. Sociaal Bestek. [journal article]. 2018 April 01;80(2):48-9 


\section{APPENDIX 2 DE PROF VRAGENLIJST}

PRoF-vragenlijst (Prive-Rooster-Fit) om de ervaren fit van het rooster met het privéleven te monitoren. De score op elke vraag varieert van 1 (heel ontevreden) tot 5 (heel tevreden). De totaalscore wordt berekend door de score op elke vraag te sommeren. De totaalscore kan variëren van 14 tot en met 70 . Een hoge score veronderstelt een hoge mate van fit van het rooster met het privéleven. Vervolgens kan in onderstaande tabel gekeken worden in welke mate men een fit ervaart tussen het rooster en het privéleven. Een score van 51 of hoger veronderstelt een goede fit van het rooster met het privéleven.

Tabel 1: Normscores voor de PRoF $(n=453)$

\begin{tabular}{llllll}
\hline "Hoge fit"* & 55 & $\leq$ & score & & \\
"Gemiddelde fit" * & 45 & $\leq$ & score & $<55$ & \\
"Lage fit" * & & & score & $<45$ & \\
M & 49.6 & & & Med & 51 \\
SD & 8.27 & & & IQR & 10 \\
SE & 0.39 & & & Min & 14 \\
& & & & Max & 70 \\
& & & & & \\
"Hoge fit" & 75e percentiel & $\leq$ & score & & \\
"Gemiddelde fit" & 25e percentiel & $\leq$ & score & $<75$ e percentiel \\
"Lage fit" & & $\leq$ & score & $<25$ e percentiel \\
\hline
\end{tabular}

\section{PRoF -vragenlijst}

Instructie De volgende vragen gaan over de (on)tevredenheid over uw onregelmatige werktijden in combinatie met andere aspecten van het dagelijks leven. Geef aan in welke mate $u$ hierover tevreden bent. Doe dit door één van de vijf cijfers te omcirkelen. De cijfers hebben de volgende betekenis:

$$
1=
$$

$2=$

$$
\mathbf{3}=
$$$$
4=
$$

$5=$

Heel ontevreden $\quad$ Ontevreden $\begin{gathered}\text { Noch ontevreden } \\ \text { Inoch tevreden }\end{gathered}$ Tevreden Heel tevreden

1. Hoe tevreden bent $\mathrm{u}$ in het algemeen met uw onregelmatig werktijden?

2. Hoe tevreden bent u met de tijd die u door onregelmatige werktijden voor uw gezin, familie en/of kennissen kunt vrijmaken?

3. Hoe tevreden bent u met de tijd die u heeft voor hobby's (sporten uitgaan, verenigingen e.d.)?

4. Hoe tevreden bent u met het benutten van de slaap vanwege onregelmatige werktijden?

5. Hoe tevreden bent $\mathrm{u}$ met het feit dat $\mathrm{u}$ vaak in het weekend moet werken door onregelmatige werktijden?

6. Hoe tevreden bent u met de mogelijkheid om door onregelmatige werktijden op doordeweekse dagen inkopen te kunnen doen (kleren, cadeaus e.d.)?

7. Hoe tevreden bent u met de mogelijkheid buiten werktijden zaken te kunnen regelen door onregelmatige werktijden (auto naar garage, schoonmaken, reparaties aan huis e.d.)?

8. Hoe tevreden bent $\mathrm{u}$ met het feit dat $\mathrm{u}$ door onregelmatige werktijden $\begin{array}{llllll}1 & 2 & 3 & 4 & 5\end{array}$ wel eens met feestdagen moet werken?

9. Hoe tevreden bent $u$ met het volgen van een normaal eetpatroon vanwege onregelmatige werktijden?

10. Hoe tevreden bent u over de combinatie onregelmatig werk-vrije tijd?

11. Hoe tevreden bent $\mathrm{u}$ over de afwisseling in uw werk door onregelmatige werktijden?

2. Hoe tevreden bent u over het contact met familie, vrienden en kennissen vanwege de onregelmatige werktijden?

13. Hoe tevreden bent $u$ in het algemeen over de dienstroostering van onregelmatige werktijden?

14. Hoe tevreden bent u over de extra inkomsten vanwege uw onregelmatige werktijden?

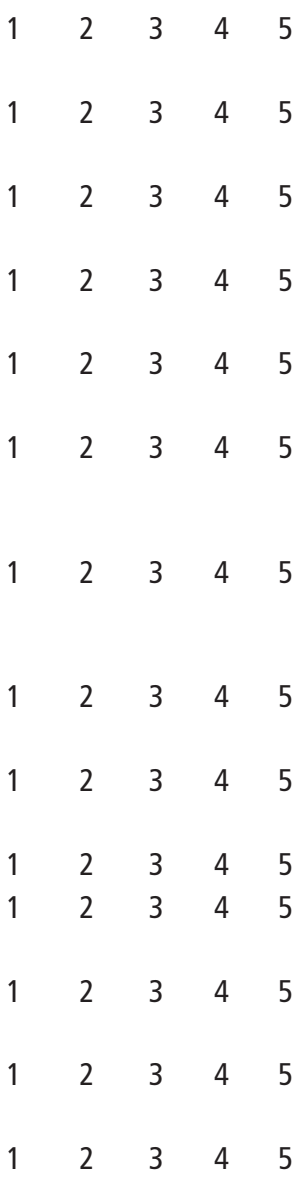




\section{DANKWOORD}

"Love to travel, but hate to arrive" (A. Einstein): een dankwoord.

Het proefschrift is klaar met het bereiken van het eindstation van deze reis. De route leidde langs lastige kruispunten waar (promotie)rooster, docentschap en privéleven met elkaar botsten. Tijdens deze reis wisselden stations van bevlogenheid, uitputting, en bezinning elkaar regelmatig af en was soms een lange 'stopover' nodig om ruimte te geven aan het docentschap en privéleven. Het was een leerzame tijd. Mijn dank gaat uit naar iedereen die zijn of haar bijdrage heeft geleverd aan het onderzoek of mij tijdens deze reis gesteund heeft. Ik zal er vast een aantal vergeten (die bedank ik tijdens het feest), maar de volgende personen zijn tijdens het proces erg belangrijk geweest.

Veel dank gaat uit naar het begeleidingsteam. Angelique, fijn dat Frans en jij mij de mogelijkheid hebben geboden om dit onderzoek uit te voeren. Het denken in oplossingen, je scherpe blik op de onderzoeksmethodiek, je aandacht voor de vertaalslag van het onderzoek naar de praktijk, en je aanhoudende drang naar nauwkeurigheid in het schrijfproces zijn erg leerzaam geweest voor mij. Pieken en dalen tijdens de reis werden door jouw doortastendheid weer op het goede spoor gezet. Frans [in memoriam], Angelique en jij vulden elkaar in de begeleiding goed aan. Helaas kon je vanwege je ziekte niet altijd aanwezig zijn tijdens de overleggen. Als je er was, genoot ik van de rustige en doordachte wijze van beslissingen nemen en je bevlogenheid voor de praktijk van arbeid en gezondheid. Het kruis dat je destijds plaatste waarvan je zei: "dat is het eindpunt van jouw proefschrift en niet mijn eindpunt", werd helaas toch jouw eindpunt. IJmert, dank dat je de rol van Frans hebt overgenomen. Jouw deskundigheid bracht een nieuwe dynamiek in het onderzoek waar ik wel even aan moest wennen, maar jouw geduld en positivisme zijn belangrijk geweest voor de afronding van het proefschrift en hebben voor de vervolmaking gezorgd. Josephine, ik sloot halverwege het project aan bij de kenniskring Arbeid en Gezondheid, en jij daarom ook halverwege bij het onderzoek, waardoor je helaas nauwelijks nog input kon leveren aan het technische ontwerp. Ik heb daarvan nauwelijks iets gemerkt in de motivatie voor het onderwerp en onderzoek. Bedankt voor je heldere en kritische beschouwingen, en de altijd snelle en behulpzame feedback. Jouw conclusie dat er verhoudingsgewijs te veel vrouwen in het begeleidingsteam zaten, heeft voor mij het belang van heterogeniteit in managementfuncties benadrukt. Inge, fijn dat je coauteur bent van twee artikelen. De enkele overlegmomenten zijn mij bijgebleven. De rust en de tijd die je nam voor overleg over de Lisrel en AMOS-analyses en methodische problemen waren erg prettig. Ik heb veel geleerd van de wijze waarop je luisterde, opties voor oplossingen besprak en in samenspraak keuzes maakte. Hi Phil, what a coincident that I met you at the Working Time Society congress in Stockholm, and moreover that you had to go for a research meeting to a city in the Netherlands to..IJmert in Maastricht! Your 'Australian' attitude during our meetings and e-mail communication was refreshing. Thanks for your helpful work on chapter five and during the congress. Yvonne, bedankt voor je bijdrage aan hoofdstuk 3 en dat je tijdelijk de rol van Josephine overnam als co-promotor. Ik zie de excelsheets af en toe nog voor mij opdoemen waarin we die enorme hoeveelheid aan roosters wisten te reduceren. Bedankt voor je maandelijkse tips voor artikelen over shiftwork en de nauwkeurigheid tijdens het schrijfproces (tot op de spaties aan toe..). Nicolle, Bedankt dat je Angeliques taken waarnam tijdens haar zwangerschapsperiode. Het was zeer waardevol in het submitten en accepteren van het artikel uit hoofdstuk 2. Veel dank aan de leescommissie: Fred Zijlstra, Allard van der Beek, Beatrice van der Heijden en Jan Hamers voor het beoordelen van dit proefschrift.

Bedankt voor de sociale steun vanuit het team Health Promotion \& Performance en in het bijzonder mijn collega's van het eerste uur in het Bisschop Hamerhuis: Kasper, Karin voor het aanhoren van en advies geven over van alles wat er plaatsvindt rondom het schrijven van een proefschrift om vervolgens alles weg te poetsen met humor of een nieuwe tegeltjeswijsheid ("beter een tunnelvisie dan geen visie"). Sarah, de kras op mijn auto herinnert mij nog steeds aan de reis naar jouw promotie in Amsterdam ("wil je op tijd zijn of niet"). Helaas zien we elkaar alleen nog tijdens Down the Rabbit Hole :-). Vanuit het team van de master Sport en Beweeginnovatie: Mark vaste collega binnen de leerlijn onderzoek: dank voor de fanatieke discussies over sport en onderzoek in willekeurige volgorde en samenhang, en José, dank voor je steun en oprechte interesse (het volgende appartement graag met rechte hoeken). Ook dank aan de vorige en huidige directie van het instituut voor Sport en Bewegen voor het faciliteren van dit promotietraject.

Bedankt broer en schoonzus! Dankzij jullie kwam ik aan deelnemers voor het onderzoek en dankzij jullie hulp werd de 'codetaal' (zie hieronder) langzaam ontrafeld. Zonder jullie had de reis, het onderzoek nooit plaatsgevonden. Daarmee kom ik bij de belangrijkste groep: het verplegend en verzorgend personeel. Mijn fascinatie voor werkroosters is ontstaan tijdens mijn werk als fysiotherapeut in een verpleeghuis. Tijdens de koffiepauzes met (te) veel gebak, was ik altijd verwonderd over jullie overleg waar, in codetaal, rekening houdend met privézaken roosters besproken en geruild werden (al beende er altijd wel één teleurgesteld weg). Bedankt dat jullie deelgenomen hebben aan het onderzoek! Het draait uiteindelijk om jullie, en ik hoop dat mijn proefschrift een bijdrage gaat leveren aan de aantrekkelijkheid van jullie beroep.

$\mathrm{Pa}$ en $\mathrm{Ma}$, het ontdekken en onderzoeken zat er volgens mij al vroeg in en jullie hebben dat altijd gestimuleerd. Wat gebeurt er als ik de kapotte gloeidraadjes van een lamp weer aan elkaar maak en de lamp in een stopcontact doe, als ik eau de toilette over het aanrecht door de keuken in banen leid en aansteek, hoe de duivenklok werkt aan de binnenzijde (door die helemaal uit elkaar te halen), of de spiegelreflexcamera... Kortom: het huis in Haalderen was altijd één groot lab als jullie niet thuis waren, het lab was ietsje kleiner als jullie er wel waren. Jullie steun en inzet voor ons gezin kenden de afgelopen jaren geen grenzen. Jullie liefde, toewijding en geduld met Maeve en Veerle maakte het makkelijker om werk, studie en familieleven te combineren. Ook bij 
hen zie ik jullie drang om een omgeving te creëren waarin plezier en ontwikkeling mogelijk is. Dank je wel voor alles!

Paulo en Katrijn, fijn dat jullie mijn paranimfen zijn. Paulo, naast dat we familie zijn, ben je ook een ontzettend goede vriend. We hebben veel 'ongeplande' reizen samen gemaakt en ik hoop dat er nog veel reizen volgen. De reis naar Frankrijk vorig jaar en de klim naar de Galibier met de fiets was geweldig en typisch voor onze reizen: een beetje planning, een flexibele houding, en alles perfect just-in-time! Dit proefschrift blijkt achteraf ook betekenisvol voor jou te zijn. Katrijn, je was een fijne collega bij zowel de bachelor als de master. Ik waardeer je vermogen om tot de basis van een onderzoek door te dringen en vervolgacties daaraan te geven. Een voorbeeld van een goede mix van denken én doen. Ook de discussies in het café na werktijd waren zeer waardevol en luidruchtig: 'never a dull moment'. Trots dat jullie een uur lang naast mij willen staan, en als je er dan toch staat, ook mijn paranimfen willen zijn.

Maeve en Veerle, jullie zijn geboren tijdens deze reis en ik heb mijn 'best' gedaan dat jullie beiden aanwezig mogen zijn tijdens deze verdediging. Bij aanvang van deze reis had ik niet verwacht dat hier twee prachtige dochters aanwezig zouden zijn. Jullie hebben mij bewust gemaakt wat het afstemmen van een (werk)rooster op het privéleven inhoudt en voor de nodige relativering gezorgd (eenhandig typen met een baby in de arm is niet efficiënt: het gebeurt beide met dezelfde voorkeursarm). Ik heb geprobeerd om geen minuut van jullie opgroeien te missen, maar papa hoeft niet meer 'naar boven' om te werken. We kunnen nog meer samen gaan genieten van de dagelijkse dingetjes. Ik bewonder jullie ambities en ideeën over jullie toekomst: houd die vast!

Mirjam, je stimuleerde mij om deze reis te starten, een reis waarbij werk en familie gecombineerd moest worden, en die niet altijd vlekkeloos verliep. Elk uurtje in de weekenden dat ik aan het proefschrift zou besteden, gingen vaak op aan gezellige en leuke activiteiten met jou, Maeve en Veerle. Dat klonk vaak toch iets aantrekkelijker, maar het 'moeten' heeft uiteindelijk wel een bijdrage geleverd. Een gezin runnen is niet (altijd) makkelijk, maar ik bewonder hoe je dat doet Het leven is vurrukkulluk met jullie. Liefs Mij.

"Nothing behind me, everything ahead of me, as is ever so on the road" (J. Kerouac)

Velen hebben interesse getoond in deze reis en dit onderzoek en zich afgevraagd of het het wel waard was, waarvoor ik het gedaan heb en wat ik ermee kan doen. Dat doe ik nog steeds, maar voor nu:

"F*ck it Dude, let's go bowling" (W. Sobchak)

$$
\text { VELBOR }
$$




\section{ABOUT THE AUTHOR}

Velibor Peters was born on the $22^{\text {nd }}$ of July 1971 in Bemmel, the Netherlands. After completing his secondary education at the Scholengemeenschap Oost-Betuwe, he obtained a bachelor degree in physiotherapy at the HAN University of Applied Sciences (HAN: Hogeschool of Arnhem and Nijmegen). After working for several years as a physiotherapist in elderly care, he started a parttime master's degree in Health Sciences, with a specialisation in Health Promotion \& Education at the Maastricht University. The subject of his master thesis was the perception of irregular working hours of nursing staff. After completing his master in 2004, he started to work for the Institute for Sports and Exercise studies (ISBS) at the HAN University of Applied Sciences and was involved in a research project on sport and exercise for employees with chronic respiratory disease. In 2008, he started his PhD trajectory at the Maastricht University, Department of Social Medicine CAPHRI (Care and Public Health Research Institute). He also started as a lecturer at the ISBS and became a member of the Occupation \& Health research group, at the HAN University of Applied Sciences. During his PhD trajectory, he followed various courses to further develop his scientific competences and carried out other research projects including a study on the relationship between a healthy lifestyle and school dropout among vocational education students. His research has led to scientific publications in international peer-reviewed journals and presentations at both national and international conferences. Since 2012, Velibor works as a lecturer and researcher in bachelor's and master's education at the HAN University of applied sciences. He has been working for the research team Health Promotion \& Performance (HPP). Within this team he focuses on the knowledge transfer between practice, education and research and his research topics are wellbeing of bachelor students, shiftwork and sustainable employability. He works as a lecturer at the master 'Sport and Movement Innovation', a master program that focuses on social innovation within the field of sport, health and human movement. 


\section{LIST OF PUBLICATIONS}

Peters, V., \& De Rijk, A. E. (2007). Onregelmatige werktijden en toch gezond? Werk, thuis en tevredenheid met onregelmatige werktijden bij zorgpersoneel in een verpleeg- en verzorgingshuis Verpleegkunde 22(3), $126-139$.

Peters, V., De Rijk, A. E., \& Boumans, N. P. (2009). Nurses' satisfaction with shiftwork and associations with work, home and health characteristics: a survey in the Netherlands. J Adv Nurs, 65(12), 2689-2700.

Peters, V., De Rijk, A. E., Engels, J., Heerkens, Y., \& Nijhuis, F. (2016). A new typology of work schedules: Evidence from a cross-sectional study among nurses working in residential elder care. Work, 54(1), 21-33.

Peters, V., de Rijk, A. E., Engels, J. A., Houkes, I., Joosten, J., \& Kant, I. (2018). Sickness Absence of Nurses Working in Residential Elder Care: The Essential Role of Psychosocial Job Resources and Home Demands. Journal of Occupational and Environmental Medicine, 60(9), e445-e454.

Peters, V., Engels, J. A., De Rijk, A. E., \& Nijhuis, F. J. (2015). Sustainable employability in shiftwork: related to types of work schedule rather than age. Int Arch Occup Environ Health.

Peters, V., Houkes, I., de Rijk, A., Bohle, P., Engels, J., \& Nijhuis, F. (2017). Welke hulpbronnen beïnvloeden de effecten van een belastend rooster van verplegend en verzorgend personeel werkzaam in de ouderenzorg? TBV-Tijdschrift voor Bedrijfs-en Verzekeringsgeneeskunde, 25(10), 476-476.

Peters, V., Houkes, I., De Rijk, A. E., Bohle, P. L., Engels, J. A., \& Nijhuis, F. J. N. (2016). Which resources moderate the effects of demanding work schedules on nurses working in residential elder care? A longitudinal study. International Journal of Nursing Studies, 58, 31-46.

Torenbeek, M. \& Peters, V. (2017). Explaining attrition and decreased effectiveness of experienced teachers: A research synthesis. Work, 57 (3), 397-407.

\section{Related presentations}

Peters, V., Engels, J., Heerkens, Y., De Rijk, A. E., \& Nijhuis, F. 'Work time arrangements and Work-Home Interference among nurses' at the EAWOP 2011 (European Association of Work and Organizational Psychology).

Peters, V., De Rijk, A. E., Engels, J., Heerkens, Y., \& Nijhuis, F. 'The associations of objective and subjective work schedule characteristics with negative and positive consequences; a survey in the Netherlands' at the ICOH-WTS congress 2011 (International Commission on Occupational Health- Working Time Society)

Peters, V., De Rijk, A. E., Engels, J., \& Nijhuis, F. Well-being of nurses working in different types of work schedules: related to shift or 'age'? at the International conference Sustainable Employability: Challenges for HRM innovation 2013.

Peters, V., De Rijk, A. E., Engels, J. \& Nijhuis, F. 'The impact of work schedule demands on nurses' work related health, negative work-home interference and work ability: do work schedule resources help? a the ICOH-WTS congres 2015 (International Commission on Occupational Health- Working Time Society).

\section{Projects}

Testjeleefstij(Test-your-lifestyle): Early signals of early school dropout?

In this project funded by a grant from ZonMw (Project number: 531001101), it was investigated whether the TJL-test has a predictive value for school drop-out and school performance of vocational educational students of the ROC-Nijmegen, and if the TJL test could ultimately serve as an instrument for early identification of students with an increased risk of early school dropout. 
